\title{
Assessment of Saltwater Intrusion in Southern Coastal Broward County, Florida
}

\section{By Michael L. Merritt}

U.S. GEOLOGICAL SURVEY

Water-Resources Investigations Report 96-4221

Prepared in cooperation with the

South Florida Water Management District and the Broward County Office of Environmental Services

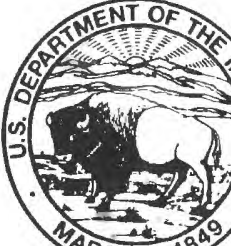




\title{
U.S. DEPARTMENT OF THE INTERIOR BRUCE BABBITT, Secretary
}

\author{
U.S. GEOLOGICAL SURVEY \\ Gordon P. Eaton, Director
}

Any use of trade, product, or firm names in this publication is for descriptive purposes only and does not imply endorsement by the U.S. Geological Survey

For additional information, write to:

Copies of this report can be purchased from:

District Chief

U.S. Geological Survey

Suite 3015

227 N. Bronough Street

Tallahassee, Florida 32301
U.S. Geological Survey

Branch of Information Services

Box 25286

Denver, CO 80225-0286 


\section{CONTENTS}

Abstract

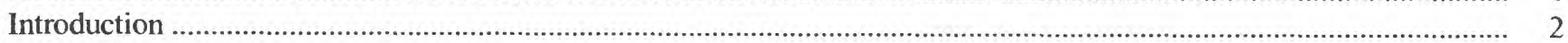

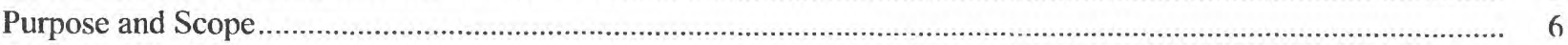

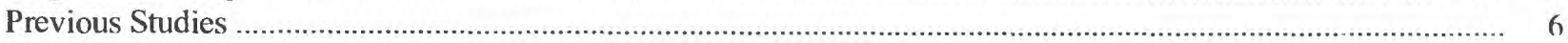

Conceptual Assumptions and Terminology ................................................................................................ 7

Hydrologic Conditions in Southern Coastal Broward County ..............................................................................

Lithology and Hydraulic Properties of the Surficial Aquifer System .............................................................. 10

Hydraulic Gradients and Water-Table Altitude Before Development................................................................. 13

Development of the Water-Management System in Southern Coastal Broward County ...................................... 19

Effect of Water-Management Controls on the Altitude of the Water Table ......................................................... 20

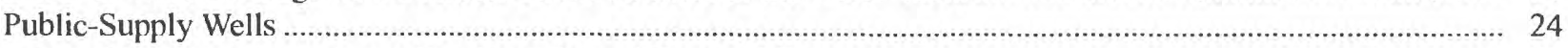

Progression of Saltwater Intrusion in Southern Coastal Broward County ............................................................. 25

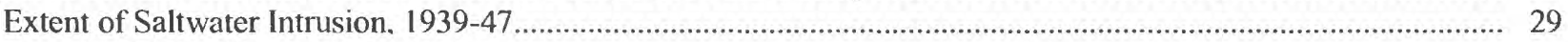

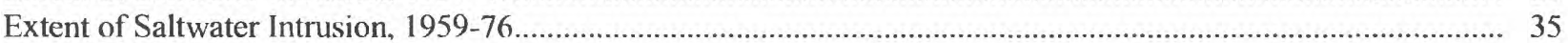

Extent of Saltwater Intrusion, 1976-94 ................................................................................................. 36

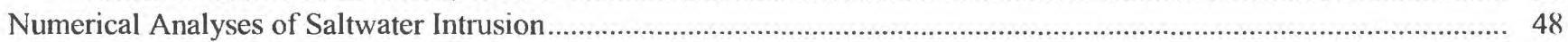

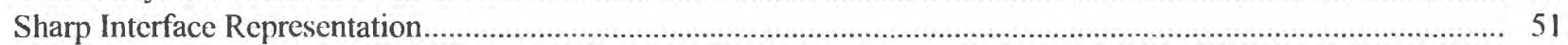

Grid Design and Parameter Value Assignments................................................................................. 53

Simulation of Predevelopment Conditions ..................................................................................................... 56

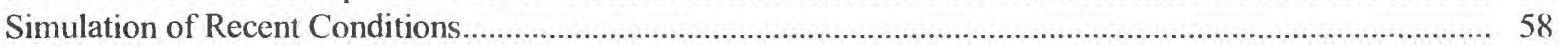

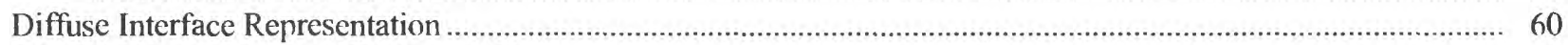

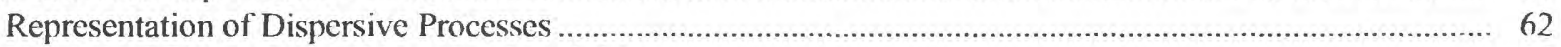

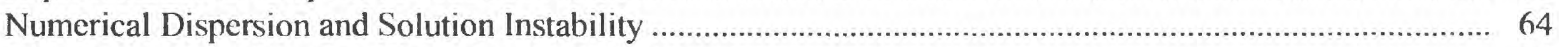

Dispersion and Advective Weighting Algorithms ............................................................................... 65

Grid Design and Parametric Coefficient Value Assignments ..................................................................... 66

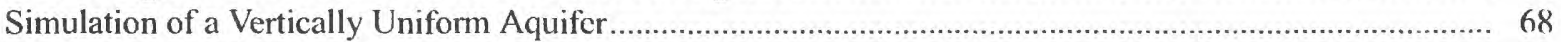

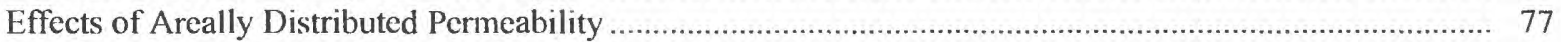

Relation of Interface Position to Saltwater Density ............................................................................ 84

Effect on Interface Position of Seasonally Varying Recharge and Evapotranspiration Rates........................ 86

Sensitivity Analyses in a Hypothetical Layered Aquifer System............................................................ 88

Relation of SWIP Cross-Sectional Analyses to the Simulation of Field Data ................................................ 104

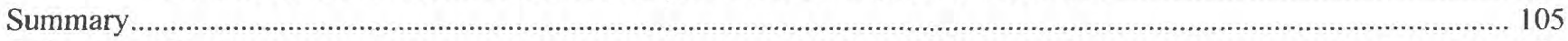

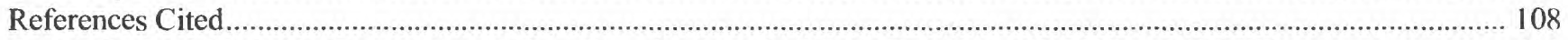

Appendix 1-Lithologic Description of Core Samples Acquired from Test Holes G-2610 and G-3472 _....................... 111

Appendix 2 Photographs of Cores from Test Holes G-2610 and G-3472 …......................................................... 121

Appendix 3-Solution Porosity Logs of Test Holes G-2328, G-2610, and G-3472 …................................................ 129

\section{FIGURES}

1-4. Maps showing:

1. The location of the study area in southeastern Broward County and northeastern Dade County, Florida

2. Location of primary drainage and tidal canals, control structures, and major municipal and private well fields in eastern Broward County and northeastern Dade County

3. Major incorporated areas in eastern Broward County

4. Location of major roads and hydrologic features in the study area and geologic section $X-X^{\prime}, Y_{-} Y^{\prime}$ and $\mathrm{Z}-\mathrm{Z}^{\prime}$

5. Geologic sections showing estimated thicknesses of formations or formation groups in southeastern

Broward County and approximate vertical position of major flow zones.

8


6. Graph showing maximum daily water levels recorded in wells G-1472 (20 feet deep) and G-1473 ( 132 feet deep) in the Hallandale Well Field in 1983 when pumping rate was near the period-ofrecord maximum...

7. Map showing major soils regions in the study area and locations of wells and gaging stations used for analysis of the effect of the north-south levee and canal system on the water-table altitude

8-10. Graphs showing:

8. Heads recorded during the 1953-61 water years at two wetlands stations in central Dade County. average heads for the time period, and monthly average heads for the time period

9. Monthly long-term average water levels in five selected wells before and after completion of the north-south levee in 1956.

10. Monthly long-term average water levels in four selected wells showing the average water-table altitude in central and eastern Broward County after 1963.

11. Cross section through the Cutler area showing the transition zone, September 18, 1958

12. Map showing locations of wells used for detecting and monitoring saltwater intrusion in the 1940's and approximate position of the saltwater front in the pumping zone in 1945

13. Graph showing chloride concentrations of water samples from well F-279, 1940-93...

14. Graph showing chloride concentrations measured in water samples from a group of wells in the 1940's

15-18. Maps showing:

15. Locations of wells used for detecting and monitoring saltwater intrusion in the 1960's and approximate position of the saltwater front in the pumping zone in 1969.

16. Chloride concentrations in water samples from wells used to monitor saltwater intrusion in the study area, 1959-94

17. Locations of wells used for detecting and monitoring saltwater intrusion in the 1970's, 1980's, and 1990's and approximate position of the saltwater front in the pumping zone in 1993.

18. Locations of wells used for detecting and monitoring saltwater intrusion in the vicinity of the Hallandale Well Field.

19. Graph showing chloride concentrations in water samples from wells used to monitor the Hallandale Well Field.

20. Graph showing vertical and horizontal position of wells used to monitor saltwater intrusion east of the Hallandale Well Field and the estimated interface position in 1970, 1985, and 1993.

21. Map showing locations of wells used for detecting and monitoring saltwater intrusion east of the Hollywood Well Field.

22-24 Graphs showing:

22. Chloride concentrations in water samples from wells used to monitor the Hollywood Well Field.....

23. Chloride concentrations in water from sampling stations along the Hollywood Canal, 1966-94

24. Chloride concentrations in water from sampling stations along the Spur Canal, 1966-94

25. Map showing locations of wells used for detecting and monitoring saltwater intrusion in the vicinity of Broward County Utilities Well Field 3A.....

26. Graph showing chloride concentrations in water samples from wells used to monitor Broward County Utilities Well Field 3A

27. Map showing spatial discretization and model boundaries used for analysis of saltwater intrusion with the sharp interface model.

28. Graph showing equilibrium positions of the predevelopment saltwater interface simulated by SHARP given various hydraulic conductivity distributions and saltwater densities

29. Graph showing position of the saltwater interface simulated by SHARP under predevelopment and current (pumping and nonpumping) conditions.

30. Map showing hypothetical saltwater toe positions simulated by SHARP under predevelopment and current conditions with and without Hallandale Well Field pumping ....

31. Grid used in SWIP cross-sectional analyses of saltwater intrusion in a vertically uniform aquifer .

32-38. Graphs showing:

32. Positions of the predevelopment 50-percent saltwater concentration line during convergence to equilibrium as simulated by SWIP.

33. Positions of the predevelopment 25- and 75-percent saltwater concentration lines during convergence to equilibrium as simulated by SWIP. 
34. Saltwater concentration lines depicting the predevelopment transition zone simulated by SWIP when longitudinal dispersivity is 400 feet...

35. Saltwater concentration lines depicting the predevelopment transition zone simulated by SWIP when longitudinal dispersivity is 40 feet.....

36. Positions of the center of the transition zone simulated by SWIP and the interface simulated by SHARP under predevelopment conditions

37. Saltwater concentration lines depicting the transition zone simulated by SWIP when longitudinal dispersivity is 400 feet and vertical dispersion is unscaled.

38. Saltwater concentration lines depicting the transition zone simulated by SWIP when longitudinal dispersivity is 40 feet and vertical dispersion is unscaled.

39. Grid used in SWIP cross-sectional analyses of the effects of a variety of hydraulic conductivity distributions on the position of the 50-percent saltwater concentration line.

40-43. Graphs showing:

40. Positions of the center of the predevelopment transition zone simulated by SWIP for various distributions of hydraulic conductivity when longitudinal dispersivity is 400 feet and vertical dispersion is scaled by a factor of 0.015

41. Relative magnitude and direction of ground-water velocity at grid cell centers for the case in which the hydraulic conductivity of the Biscayne aquifer is 10,000 feet per day everywhere

42. Positions of the center of the predevelopment transition zone simulated by SWIP for three values of saltwater density

43. Positions of the predevelopment transition zone simulated by SWIP for average seasonal and long-term steady-state conditions.

44. Grid used in SWIP cross-sectional analyses of the effects of vertical layering and numerical algorithm selection

45-54. Graphs showing:

45. Positions of the 50-percent saltwater concentration line during convergence to equilibrium of the 28-layer model when the initial position is from an iterative Ghyben-Herzberg procedure.

46. Positions of the 50-percent saltwater concentration line during convergence to equilibrium of the 28-layer model when the initial position is a vertical line at the coast

47. Equilibrium positions of the 50-percent saltwater concentration line simulated by the 28 -layer model when vertical line and iterative Ghyben-Herzberg initial positions are used.

48. Simulated positions of the 50 -percent saltwater concentration line showing the effects of grouping 10 hydraulically distinct layers into two zones each assigned a mean average hydraulic conductivity ........

49. Simulated interface positions using various vertical dispersion and advective weighting methods when longitudinal dispersivity is 400 feet and transverse dispersivity is zero

50. Simulated interface positions using various vertical dispersion and advective weighting methods when longitudinal dispersivity is 40 feet and transverse dispersivity is zero.

51. Simulated interface positions using various vertical dispersion and advective weighting methods when longitudinal dispersivity is 4 feet and transverse dispersivity is zero

52. Simulated interface positions using various longitudinal dispersivity specifications when modified dispersion algorithms are used and vertical dispersion is scaled within hydraulically uniform units

53. Simulated interface positions using various longitudinal dispersivity specifications when modified dispersion algorithms are used and vertical dispersion is not scaled within hydraulically uniform units .

54. Simulated interface positions using various longitudinal dispersivity specifications when standard dispersion algorithms are used that do not entail any special treatment of vertical dispersion

\section{TABLES}

1. Measured or estimated average seasonal ranges of heads and average annual heads in selected wells and at selected gaging stations in Broward and Dade Counties in successive time periods

2. Chloride concentrations determined by analyses of water samples from selected wells other than from routinely scheduled sampling, 1940-91 


\title{
Assessment of Saltwater Intrusion in Southern Coastal Broward County, Florida
}

\author{
By Michael L. Merritt
}

\section{Abstract}

Of the counties in southeastern Florida, Broward County has experienced some of the most severe effects of saltwater intrusion into the surficial Biscayne aquifer because, before 1950, most public water-supply well fields in the county were constructed near the principal early population centers located less than 5 miles from the Atlantic Ocean. The construction of major regional drainage canals in the early 20th century caused a lowering of the water table and a gradual inland movement of the saltwater front toward the well fields. The U.S. Geological Survey began field investigations of saltwater intrusion in the Biscayne aquifer of southeastern Broward County in 1939. As part of the present study, the positions of the saltwater front in 1945, 1969, and 1993 were estimated using chloride concentrations of water samples collected between 1939 and 1994 from various monitoring and exploratory wells. The data indicate that, between 1945 and 1993, the saltwater front has moved as much as 0.5 mile inland in parts of the study area.

The position and movement of the saltwater interface were simulated numerically to help determine which of the various hydrologic factors and water-management features characterizing the coastal subsurface environment and its alteration by man are of significance in increasing or decreasing the degree of saltwater intrusion. Two representational methods were applied by the selection and use of appropriate model codes. The SHARP code simulates the position of the saltwater front as a sharp interface, which implies that no transition zone (a zone in which a gradational change between freshwater and saltwater occurs) separates freshwater and saltwater. The Subsurface Waste Injection Program (SWIP) code simulates a two-fluid, variable-density system using a convective-diffusion approach that includes a representation of the transition zone that occurs between the freshwater and saltwater bodies. The models were applied to: (1) approximately replicate predevelopment and current positions of the interface in the study area; and (2) study the relative importance of various factors affecting the interface position. The model analyses assumed a conceptual model of uniform easterly flow in the aquifer toward points of offshore discharge to tidewater.

Measurements of water-table altitude and the depth to the interface in the study area exhibit an interrelation that differs substantially from the classical Ghyben-Herzberg relation. However, both model codes simulated water-table altitudes and interface positions that were generally consistent with the Ghyben-Herzberg relation and differed substantially from observed data. The simulated interface positions were inland of the known positions, and simulated water-table altitudes were higher than measured ones. The SHARP and SWIP simulations were in general agreement with each other when a low value of longitudinal dispersivity was specified in the SWIP simulation and also for higher values of longitudinal dispersivity when modified dispersion algorithms were used in SWIP that greatly reduced the simulated degree of vertical dispersion. 
Sensitivity analyses performed using the SHARP code indicated simulation results to be relatively insensitive to a substantial change in the specified slope of the base of the aquifer and moderately sensitive to a 150-percent change in net atmospheric recharge to the aquifer (rainfall minus evapotranspiration). Representing wellfield pumping by the City of Hallandale had only a minor, localized influence on the simulated regional interface position. Using various crosssectional grid designs in applications of the SWIP code, near convergence of all lines of equal concentration in the transition zone was achieved within a simulation time of 10 years. The simulated equilibrium interface location was sensitive to substantial spatial variations in the specified hydraulic conductivity values, but was relatively insensitive to seasonally varying boundary and recharge conditions or to realistic variations in saltwater density. A 28-layer uniform thickness cross-sectional grid was used to study the effects of complex hydraulic-conductivity layering. This model was also used for an analysis of the sensitivity of the simulated position and degree of dispersion of the interface to different algorithms for computing vertical dispersion and to the value of longitudinal dispersivity. Some simulations suggested the occurrence of a saltwater convection cell that extends seaward from the offshore freshwater discharge location.

\section{INTRODUCTION}

Of the counties in southeastern Florida, Broward and Dade Counties have experienced the most severe effects of saltwater intrusion in the surficial Biscayne aquifer. The severity of the problem in Broward County (fig. 1) is largely related to its geography. Most early settlement occurred on a narrow coastal strip of land not more than $5 \mathrm{mi}$ (miles) wide, the "coastal ridge," where land elevations reach $20 \mathrm{ft}$ (feet) above sea level. Inland, a strip of marginal wetlands and pine and cypress forest of lower elevation separated the coastal ridge from the even lower wetlands of the Everglades. Most well fields (fig. 2) were constructed near the population centers of the coastal ridge. However, the construction of major regional drainage canals, three of which (Hillsboro, North New River, and Miami Canals) transect Broward County (fig. 1), caused a lowering of the water table (Parker and others, 1955, p. 9) that facilitated the gradual inland movement of the coastal saltwater front toward the well fields.

The construction of inland levees for flood prevention after heavy rains lowered peak water-table altitudes in the area of former marginal wetlands and pine and cypress forest, making possible the development of inland suburban communities such as the Cities of Sunrise, Margate, Davie, Pembroke Pines, Miramar, Tamarac, Lauderhill, Coral Springs, and Plantation (fig. 3). The construction of long tidal canals extending inland from or parallel to the coast to provide ocean access to boat owners further lowered the water table and also allowed saltwater to enter the aquifer as direct seepage from canals in inland areas. In recent years, pumping has had to be curtailed at most wells used for supply by the cities of Hallandale and Dania. Water managers are concerned about the future availability of potable water from well fields used by the Cities of Deerfield Beach, Pompano Beach, Fort Lauderdale, and Hollywood (fig. 2). The problem of water availability in Broward County is made more complex by the decentralized nature of public water-supply management, most individual communities owning and managing their own source of water supply. However, even one of the small well fields owned by Broward County, BCU-3A (fig. 2, no. 27 ) is threatened with saltwater intrusion from a tidal canal.

Water managers have endeavored to use every means at their disposal for making quantitative analyses of the position of the saltwater interface and the potential rate and extent of its movement in response to changes in water-table altitude. However, water managers have been forced to rely primarily on direct measurements of interface movement, usually based on analyses of water samples obtained from networks of monitoring wells. Surface-geophysical measurements have promise as a quick means of obtaining data over a large area that would be significantly less costly than well construction, but methods of relating measurements of the conductance or resistance of subsurface fluids to the depth of the interface between freshwater and saltwater are still in the process of development and are difficult to apply in urbanized areas. 


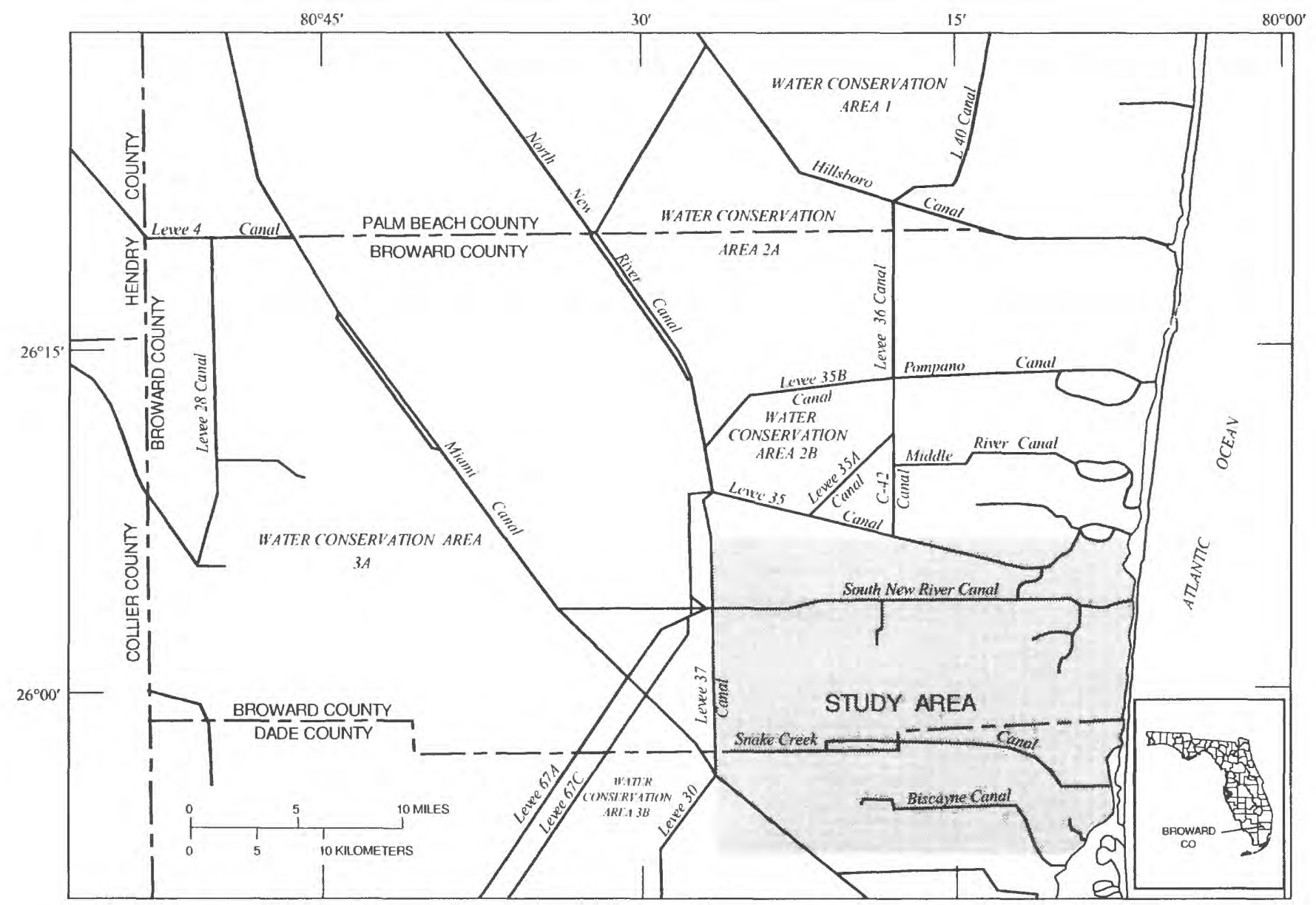

Figure 1. The location of the study area in southeastern Broward County and northeastern Dade County, Florida.

Numerical models of the transport of solutes in ground water have been especially attractive to water managers because of their potential for providing quantitative estimates of interface movement on either a regional or local basis. However, numerical simulation of the position and movement of the saltwater interface, though theoretically within the range of capabilities of existing model codes, has proven to be subject to practical restrictions that have largely prevented its application to more than a handful of situations. One class of numerical models that solve the advective-diffusion equation for solute transport has the drawback that numerical restrictions related to the computation of solute transport over large time and spatial scales require lengthy and time-consuming calculations that often prove to be economically prohibitive. As the capability of computing equipment rapidly improves, however, and such equipment becomes available at lower cost, this obstacle to the use of numerical models is being overcome. Another problem related to the numerical simulation of saltwater intrusion with solute-transport models is that transport processes occur in spatial domains that are large horizontally compared to vertically. This leads to model designs with grid cells that may have a 1,000:1 ratio of horizontal to vertical dimensions, which can lead to various kinds of numerical approximation error. Merritt (1993) and other investigators have contributed to the development of more sophisticated methods of representing the transport of solutes in ground water so that problems of this nature may be solved more effectively.

Another class of models that solves equations for a sharp interface is computationally more efficient in steady-state applications, but is less flexible in representing complex hydrologic features. In this study, both solute transport and sharp interface models were used. It is in this context of increasingly sophisticated numerical simulation techniques and increasing computational capability, and in the context of the increasing severity of the problems caused by saltwater intrusion in southeastern Florida, that the U.S. Geological Survey (USGS), in cooperation with the South Florida Water Management District and the Broward 


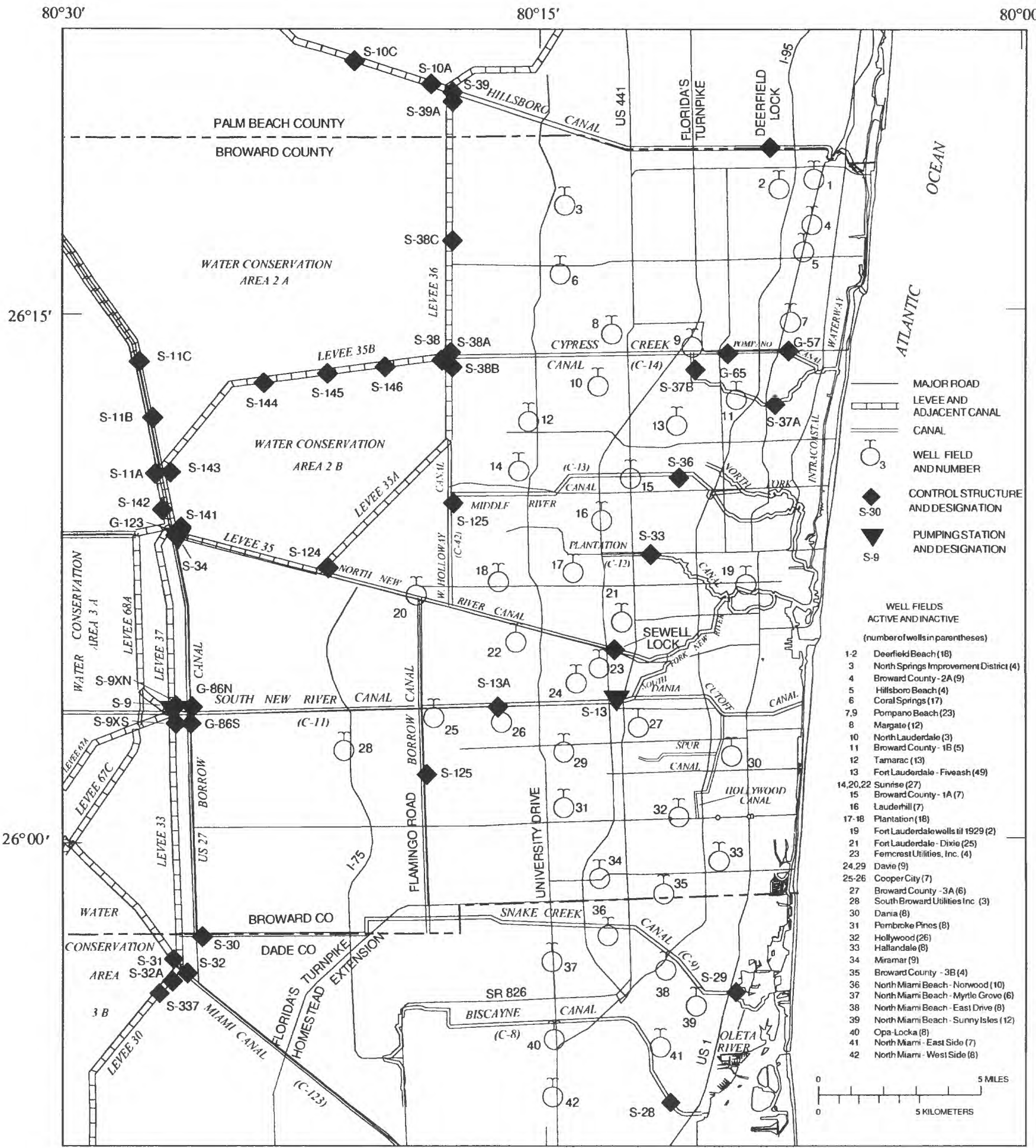

Figure 2. Location of primary drainage and tidal canals, control structures, and major municipal and private well fields in eastern Broward County and northeastern Dade County. 


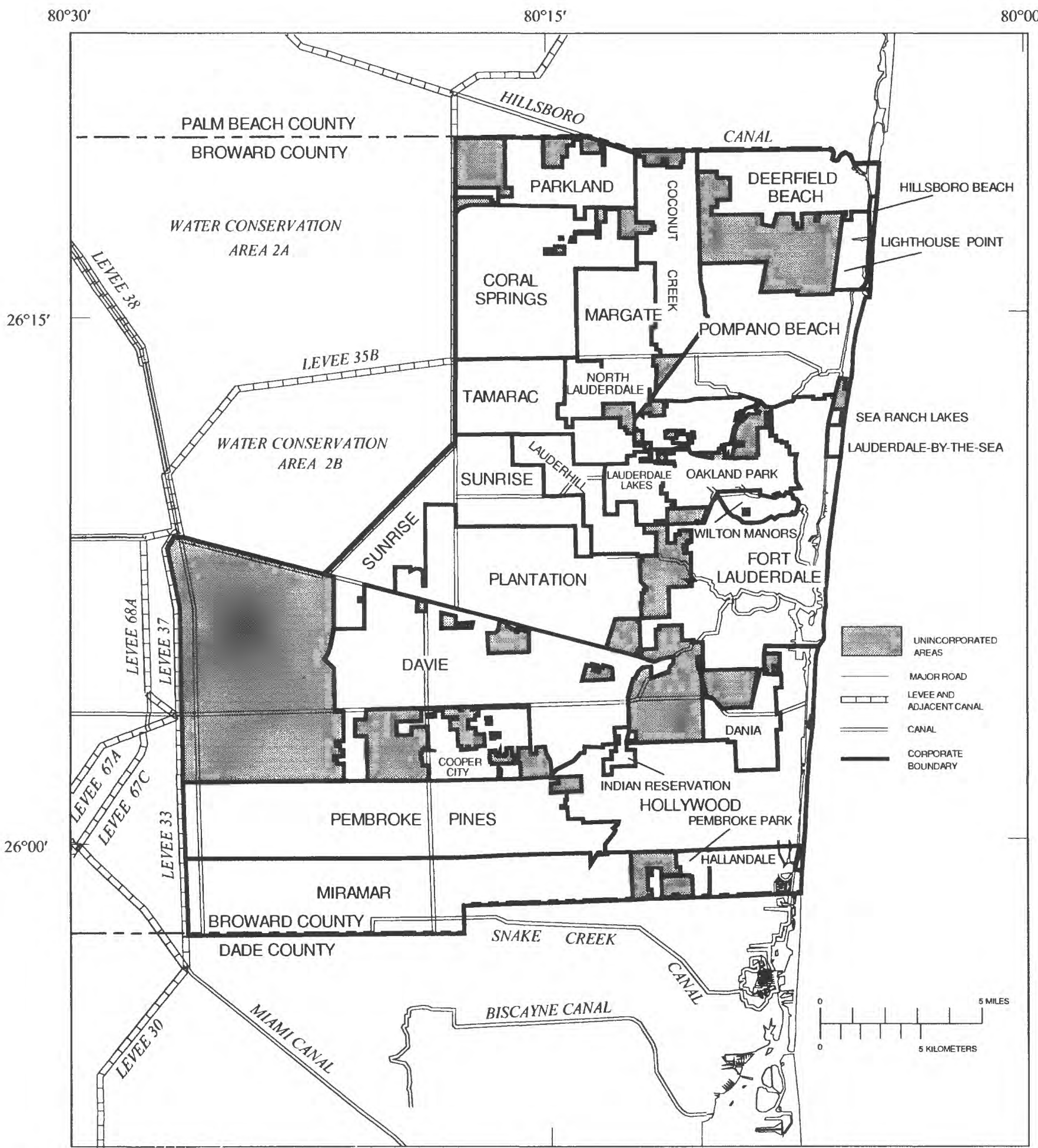

Figure 3. Major incorporated areas in eastern Broward County. 
County Office of Environmental Services, has conducted a study of saltwater intrusion in southern coastal Broward County.

\section{Purpose and Scope}

The purposes of this report are to: (1) assess the problem of saltwater intrusion in the surficial aquifer system, which includes the Biscayne aquifer, near the coast of southern Broward County, and (2) describe the results of numerical simulation procedures that have been applied to represent the past and present position and movement of the interface between freshwater and saltwater in the area.

The hydrology of the area is briefly reprised based on previous studies, and the development of the water-management system is described briefly to provide a basis for the analysis of trends in regional water-table altitudes that might relate to seawater intrusion near the coast. The data base of chloride concentration data obtained from the developing network of monitoring wells and other data from preexisting wells is presented as a basis for describing the saltwater intrusion that has occurred since the first data were acquired. The saltwater front position in 1945, 1969 , and 1993 is estimated as a basis for subsequent numerical simulation work.

The analyses with numerical models, including SHARP (Essaid, 1990) and the Subsurface Waste Injection Program, SWIP (INTERCOMP Resource Development and Engineering, Inc., 1976; INTERA Environmental Consultants, Inc., 1979), are presented from the point of view that little has been published describing the application of such models, particularly the class of diffuse-interface models represented by SWIP, to the problem of saltwater intrusion. Therefore, some exposition is required to describe how SWIP is applied to the saltwater intrusion problem and how the model behaves when so applied. The subsequent description of sensitivity analyses has a dual purpose in: (1) further describing the application and behavior of the model, and (2) deriving interpretations that describe the mechanisms of the saltwater intrusion process in the study area. Also included in the discussion of the model applications is a brief description of mathematical modifications incorporated into the SWIP code to facilitate the simulation of the transition zone between freshwater and saltwater.

Various interpretations derived from the analyses with numerical models that relate to the study area have two focuses: (1) to assess the effect of various hydrogeologic factors in determining the equilibrium position of the interface in a generalized aquifer with hydraulic layering resembling that of the surficial aquifer in the study area; and (2) to compare simulated interface positions with measurements of hydraulic head and chloride concentration in the study area as part of an attempt to resolve discrepancies between observed data and empirical rules (the GhybenHerzberg relation) that describe the anticipated relation between head and interface depth.

\section{Previous Studies}

A simple theoretical description of the relative position of saltwater underlying a body of freshwater in the subsurface was formulated by Badon-Ghyben (1889) and Herzberg (1901). Hubbert (1940) provided an improved method of determining the vertical position of the freshwater-saltwater interface by using the principle of continuity of pressure at the interface. A mathematical analysis of the movement of the interface in response to changes in the hydraulic regime was conducted by Bear and Dagan (1964). The results of the work of these investigators have been summarized by Reilly and Goodman (1985). The influence of the zone of dispersion separating freshwater and saltwater and the dynamics of the saltwater zone were recognized by Cooper (1959), and a program of intensive data collection and interpretation was conducted in Florida by Kohout (1960) to test these hypotheses. A further discussion of the interaction between freshwater and saltwater was presented by Cooper and others (1964).

With the advent of high-speed digital computers, attempts were begun to use numerical simulation techniques to simulate the position of the freshwater-saltwater interface. A simulation technique based on the method of characteristics and taking into account the process of dispersion in causing a diffused interface was described by Pinder and Cooper (1970). Results of their cross-sectional model compared well with corresponding analytical solutions. Lee and Cheng (1974) applied the finite-difference method to the same purpose, with results that compared well with analytical solutions and showed some qualitative agreement with the observations of Kohout (1960). Similar results were obtained from an application of the Galerkin finite-element method (Segol and others, 1975; Segol and Pinder, 1976).

Field investigations of the position of the saltwater front in the surficial Biscayne aquifer of coastal southeastern Florida and the inland movement of seawater that was threatening coastal well fields were 
begun by the USGS in 1939. The salinities of water samples from wells were measured, and available historical information describing the predevelopment hydrology of the area was reviewed by Parker and others (1955) and used to approximately describe the extent of saltwater intrusion that had occurred since the construction of drainage canals began in the early 1900 's. Although the work of Parker and others (1955) had its principal focus on the Miami area of Dade County, observation wells were also constructed in Fort Lauderdale in Broward County to support a parallel assessment of saltwater intrusion in the New River Basin. The history of saltwater intrusion in the New River Basin was also discussed by Vorhis (1948) and Sherwood (1959). A synoptic assessment of saltwater intrusion in north-central Broward County was presented by Grantham and Sherwood (1968).

The position of the saltwater front at the time of reporting was determined as part of various areal hydrological studies, including those conducted in the Snake Creek area (Kohout and Leach, 1964), near Pompano Beach (Tarver, 1964), near Hallandale (Bearden, 1972), near Hollywood (Bearden, 1974), and for all of Broward County (Sherwood and others, 1973). A regional study of the surficial aquifer system, which includes the Biscayne aquifer as the upper part, was performed by the USGS in the early 1980's. As part of that study, lithological descriptions of samples from 27 test holes and 8 correlative geologic sections were prepared by Causaras (1985) and a water-quality assessment was presented by Howie (1987). Several of the drilling sites for the study were in or near the saltwater-intruded zone, and the data included descriptions of the lithology and vertical salinity profiles at the locations of several test holes in the saltwaterintruded area. A regional description of the hydraulic characteristics of the surficial aquifer system in Broward County was later presented by Fish (1988). A study of saltwater intrusion in the Hallandale area that included analyses with numerical models was conducted by GEOTRANS, Inc. (Anderson and others, 1988).

\section{Conceptual Assumptions and Terminology}

Throughout this report, the terms "freshwater" and "saltwater" are used in a conceptual sense to refer to separate bodies of water that have substantially different concentrations of dissolved minerals. In most instances, the conceptual view that "freshwater" means potable water with a chloride concentration less than $250 \mathrm{mg} / \mathrm{L}$ (milligrams per liter) and a dissolved solids concentration less than $500 \mathrm{mg} / \mathrm{L}$, and that "saltwater" means water with the mineral constituents of average seawater, is adequate for an understanding of the material presented. However, in some parts of the discussion, "saltwater" refers to water that is mineralized but in concentrations that differ considerably from those of seawater. Where a specific reference to ocean water is intended, the term "seawater" is used.

The densities assigned to freshwater and saltwater in model analyses are stated throughout the report in units of "specific weight" or "weight density" (pound-force per cubic foot), and the term is shortened to "density" to reduce verbiage. Because altitude varies little in the study area, no error is introduced by the implicit assumption of a constant value of gravitational acceleration.

Seawater is assumed to have a weight density of $64.0 \mathrm{lb} / \mathrm{ft}^{3}$ (pounds per cubic foot), which is generally representative of natural seawater. However, it is understood that this value is used in an average or representative sense, as the density of natural seawater varies throughout the world's oceans.

Where water is ponded above land surface, the altitude of its surface with respect to sea level is termed "stage." When the water table is below land surface, its altitude with respect to sea level is termed the "water-table altitude." The altitude of the water surface within a well, expressed with respect to sea level, is termed the "water level" in the well and is a local measure of water-table altitude. The term "head" is a conceptual term referring to the potential energy related to the altitude of a water body, whether below land surface or emergent above land surface. "Stage" and "water-table altitude" are both measures of head, and the term "head" is occasionally used in this report to refer collectively to a group of measurements that includes both stage and water-table altitude measurements.

"Permeability" (or "intrinsic permeability") is a quantitative measure of the facility with which fluids are transmitted in a subsurface formation subjected to a head gradient. Hydraulic conductivity is a similar quantitative measure in different units that refers to a fluid of specific density and hydrodynamic viscosity. In this report, "permeability" is often used in a conceptual sense to refer generally to the transmitting facility of a subsurface formation or layers of lithologically similar materials within a formation. Hydraulic conductivity is used in a more specific sense to refer to values or ranges of values of this quantitative measure.

"Saltwater front" receives a carefully worded definition in the section in which its progressive inland movement is described. It is not to be confused with 
the term "saltwater interface," which refers to the entire zone of transitional water quality that lies between freshwater and saltwater. Many simulation analyses are evaluated by a consideration of the position of the 50-percent saltwater concentration line (and in some instances, the 25- and 75-percent saltwater concentration lines) within the saltwater interface.

\section{HYDROLOGIC CONDITIONS IN SOUTHERN COASTAL BROWARD COUNTY}

Southeastern Broward County is an area of generally flat terrain where land-surface elevation does not exceed $15 \mathrm{ft}$ above sea level. The eastern $2.5-\mathrm{mi} \mathrm{sec}$ tion of the study area (fig. 1) is part of the Atlantic Coastal Ridge. Land-surface elevation slopes downward to the east from within about 1.5 to $2 \mathrm{mi}$ of the coast. Between the coastal ridge and Water Conservation Area 3A, land-surface elevations are lower than those of the coastal ridge. In the predevelopment era, the water-conservation areas were part of the principal flow system of the Everglades.

The study area has been reported to receive slightly more than $60 \mathrm{in}$. (inches) of rainfall annually (Bearden, 1972; Bearden, 1974; MacVicar, 1983). To determine the typical pattern of seasonal variation, monthly totals from a rainfall station in Fort Lauderdale (fig. 4, National Oceanic and Atmospheric Administration (NOAA) rainfall station 6069) were averaged over the period of record from 1914 to 1992. The average monthly rainfall totals, in inches, are as follows:

\begin{tabular}{|c|c|c|c|}
\hline Month & $\begin{array}{c}\text { Average } \\
\text { monthly } \\
\text { rainfall } \\
\text { (inches) }\end{array}$ & Month & $\begin{array}{c}\text { Average } \\
\text { monthly } \\
\text { rainfall } \\
\text { (inches) }\end{array}$ \\
\hline \hline January & 2.50 & July & 6.27 \\
\hline February & 2.30 & August & 6.71 \\
\hline March & 2.76 & September & 8.20 \\
\hline April & 3.95 & October & 8.27 \\
\hline May & 6.10 & November & 3.70 \\
\hline June & 8.49 & December & 2.51 \\
\hline \multicolumn{2}{|c|}{ Average annual rainfall 61.76 inches } \\
\hline
\end{tabular}

Since 1970, the average for October has been only $5.25 \mathrm{in}$. During the period 1914-92, 71 percent of the annual average rainfall occurred during the months of May through October. Evapotranspiration rates in the study area are high and tend to vary with the amount of solar radiation (Stephens and Stewart, 1963), which implies a strongly seasonal variation (higher in summer, lower in winter). Calibration of a regional flow model in southern Dade County, about 10 mi south of the study area (Merritt, 1996b), was accomplished by specifying monthly maximum evapotranspiration rates as shown in the table listed below (values in inches per day). These rates were similar to the average U.S. Weather Bureau pan evaporation rates for a 5-year period in southern Florida cited by Stewart and Mills (1967).

\begin{tabular}{|c|c|}
\hline Month & $\begin{array}{c}\text { Maximum } \\
\text { evapotranspiration rates } \\
\text { (inches per day) }\end{array}$ \\
\hline \hline January & 0.08 \\
\hline February & 0.11 \\
\hline March & 0.14 \\
\hline April & 0.17 \\
\hline May & 0.18 \\
\hline June-October & 0.21 \\
\hline November & 0.12 \\
\hline December & 0.11 \\
\hline
\end{tabular}

The quality of water in the surficial aquifer system, which includes the Biscayne aquifer (the sole source of water supply in the study area), was described by Howie (1987) based on results of water sampling during test drilling with dual-tube reverse-air equipment: "Excluding those areas strongly affected by seawater intrusion, specific conductance of ground water from the coastal ridge ranges from 270 to 1,370 $\mu \mathrm{S} / \mathrm{cm}$ (microsiemens per centimeter), and dissolved chloride (concentrations) range from 14 to $260 \mathrm{mg} / \mathrm{L}$." In highly permeable rocks of the Biscayne aquifer flushed by rainfall recharge and rapid flow, the average values are in the low part of those ranges. Characteristic values of specific conductance and chloride concentration in these regions are about $500 \mu \mathrm{S} / \mathrm{cm}$ and $20 \mathrm{mg} / \mathrm{L}$, respectively.

The hydrogeologic features that have the greatest pertinence for the analysis of saltwater intrusion are 


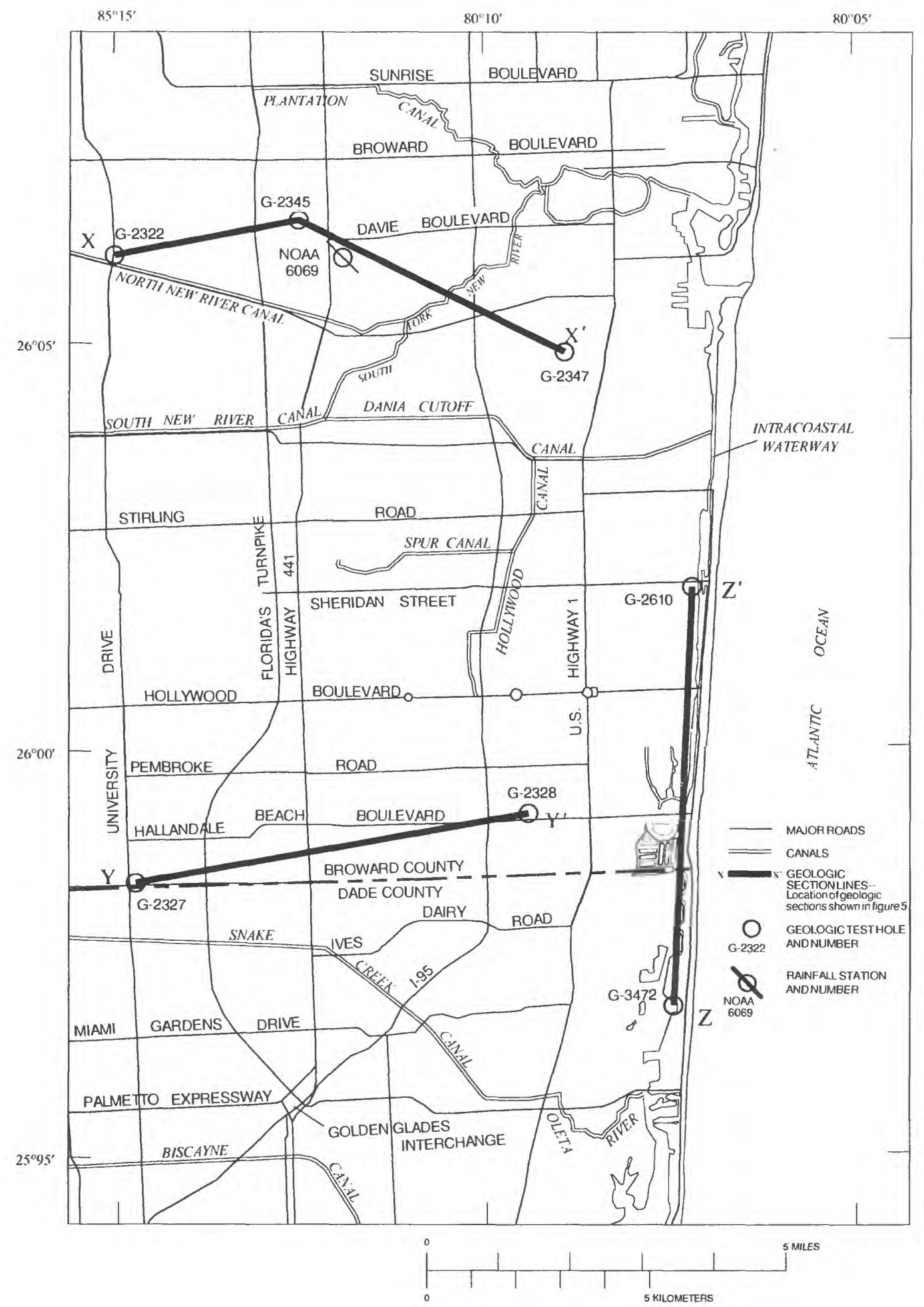

Figure 4. Location of major roads and hydrologic features in the study area and geologic sections $\mathrm{X}-\mathrm{X}^{\prime}, \mathrm{Y}-\mathrm{Y}^{\prime}$, and $\mathrm{Z}-\mathrm{Z}^{\prime}$. 
the lithologic and hydraulic properties of the surficial aquifer system. The effects of water-management practices on the water-table altitude and the flow regime of the Biscayne aquifer are also pertinent to an analysis of the intrusion problem. These subjects are discussed in the following sections.

\section{Lithology and Hydraulic Properties of the Surficial Aquifer System}

The surficial aquifer system in Broward County, as described in detail by Causaras (1985) and Fish (1988), is comprised of a sequence of Holocene, Pleistocene, and Pliocene deposits that are composed of carbonates and sands that may be consolidated or unconsolidated and contain negligible to significant amounts of silt or shelly and oolitic material. The geologic sections shown in figure 5 depict the depth intervals that correspond to deposits of Pleistocene and Pliocene age. Section locations are shown in figure 4.

The late Pleistocene Pamlico Sand is near the surface in five of the seven wells shown in figure 4, the exceptions being sites G-2347 and G-3472. Lower Pleistocene deposits in the coastal region of southeastern Florida usually occur as an interfingering of the following formations, each representing a particular type of rock and depositional environment:

- Anastasia Formation: Sands, sandstones, and coquinas, sometimes shelly or silty, that represent near-shore and beach bar deposits:

- Key Largo Limestone: Coralline material that represents fossil coral reefs;

- Fort Thompson Formation: Consolidated carbonates that represent deeper littoral to shallow pelagic (or occasionally freshwater) lime deposition; and

- Miami Limestone: Carbonate deposits that contain bryozoans or worm-burrowed sediments (formerly the Miami Oolite) from a relatively shallow marine environment.

Each of the four Pleistocene formations, where present, occur in a varying sequence and at various depths at the seven well sites shown in figure 4. Because the variation is complex and has been described by Causaras (1985) for sections X-X' and $Y-Y^{\prime}$, details are omitted here. (At a given location, one or more of the formations may be absent, or may occur in multiple depth intervals separated by deposits of the other formations.) Data from test holes G-2610 and G-3472, cored as part of this study, have not been published previously and are of particular interest because the geologic environment near the ocean is rarely investigated, this being a saltwater-intruded zone of little economic use. Descriptions of the cores from these test holes are presented in appendix 1. Photographs of the cores are presented in appendix 2 .

The predominant formations of Pleistocene age in the study area are the Anastasia Formation and Key Largo Limestone, which represent the near-shore environment that characterized the study area in Pleistocene times. Farther inland and west of the study area, the Fort Thompson Formation and Miami Limestone predominate. Beneath the Pleistocene formations is the Tamiami Formation of Pliocene age (Causaras, 1985). Within the study area, the Tamiami Formation is composed of alternating beds of limestone, sandstone, and sand. The limestone beds tend to be sandy, and all materials tend to be shelly or silty. Beneath the Tamiami Formation is the Hawthorn Formation of Miocene age. In the western part of the study area, the upper part of the Hawthorn Formation is characterized by limy silt or mud, but in wells G-2347 and G-2328, the Hawthorn either is not penetrated or is characterized by a horizontal facies change from the clay present farther west to consolidated limestone near the coast. In test holes G-2610 and G-3472, the Hawthorn was not penetrated, according to J.F. Whitley (U.S. Geological Survey, written commun., 1990). Generally, the top of the Hawthorn Formation is considered to be the base of the surficial aquifer system.

The Tamiami Formation dips toward the coast as the interfingering of the various overlying Pleistocene formations and the lithology of the Tamiami Formation and that of the underlying Hawthorn Formation become more complex (Causaras, 1985). It is possible that some groups of Pleistocene formation deposits, together with the underlying Tamiami and Hawthorn Formations, continue eastward to the edge of the Atlantic Shelf, although this cannot be verified because of the lack of lithologic data east of section $\mathrm{Z}-\mathrm{Z}^{\prime}$. The ocean depths are about $300 \mathrm{ft}$ at 2 to $2.5 \mathrm{mi}$ offshore and about $650 \mathrm{ft}$ at $4 \mathrm{mi}$ offshore; farther east, the ocean bottom slope decreases. Ocean depths are greatest (about 2,300 to 2,500 ft) at about $35 \mathrm{mi}$ offshore. Farther toward the east, the ocean bottom rises toward the Great Bahama Bank.

Generally, the highly permeable Biscayne aquifer is considered to be comprised of the Pleistocene formations (fig. 5). Near the coast, however, sections of lower formations are included in the Biscayne aquifer because they also are characterized by high permeability. The top of the Biscayne aquifer occurs at about 50 $\mathrm{ft}$ below land surface near the western ends of sections $\mathrm{X}-\mathrm{X}^{\prime}$ and $\mathrm{Y}-\mathrm{Y}^{\prime}$ (near University Drive) and at about $35 \mathrm{ft}$ below land surface near the eastern ends of sections X-X' and Y-Y' (Fish, 1988, figs. 17 and 18). At 


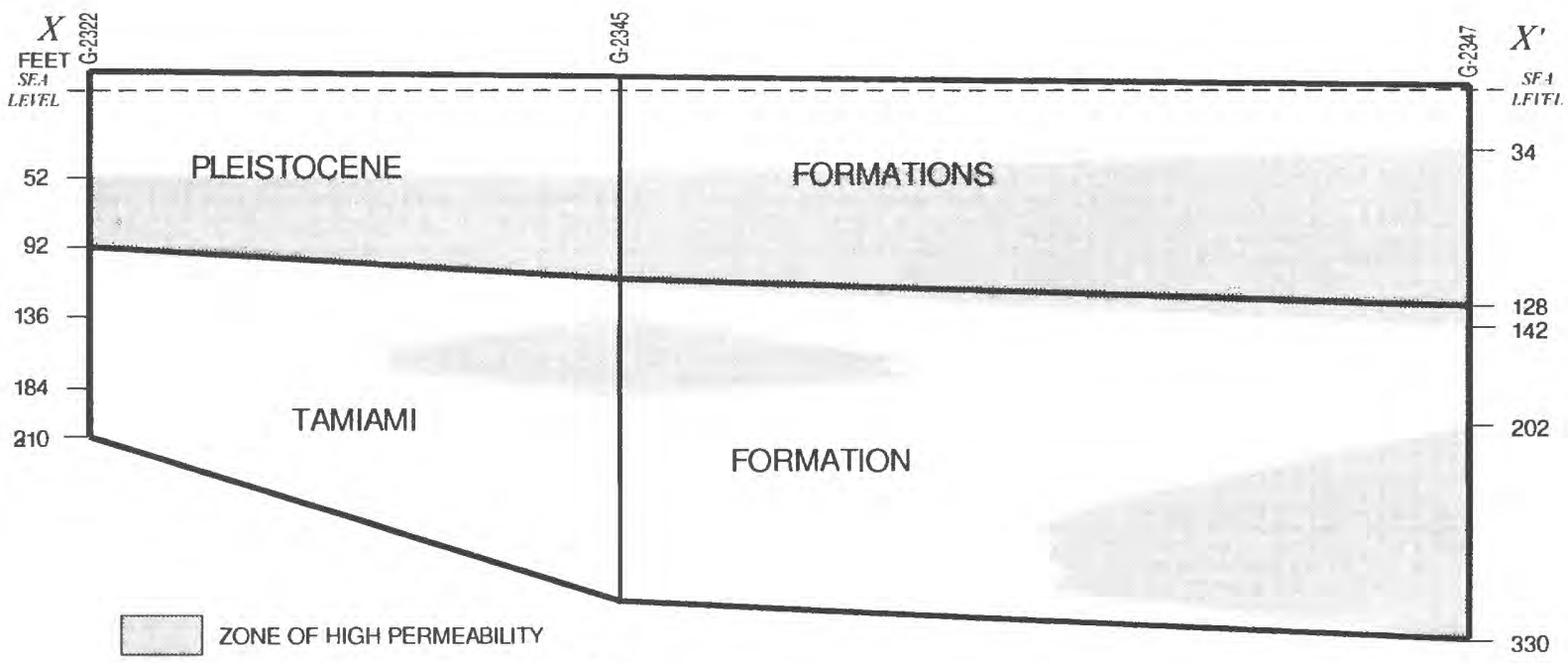

G-2328 IS GEOLOGIC TEST HOLE DESIGNATION
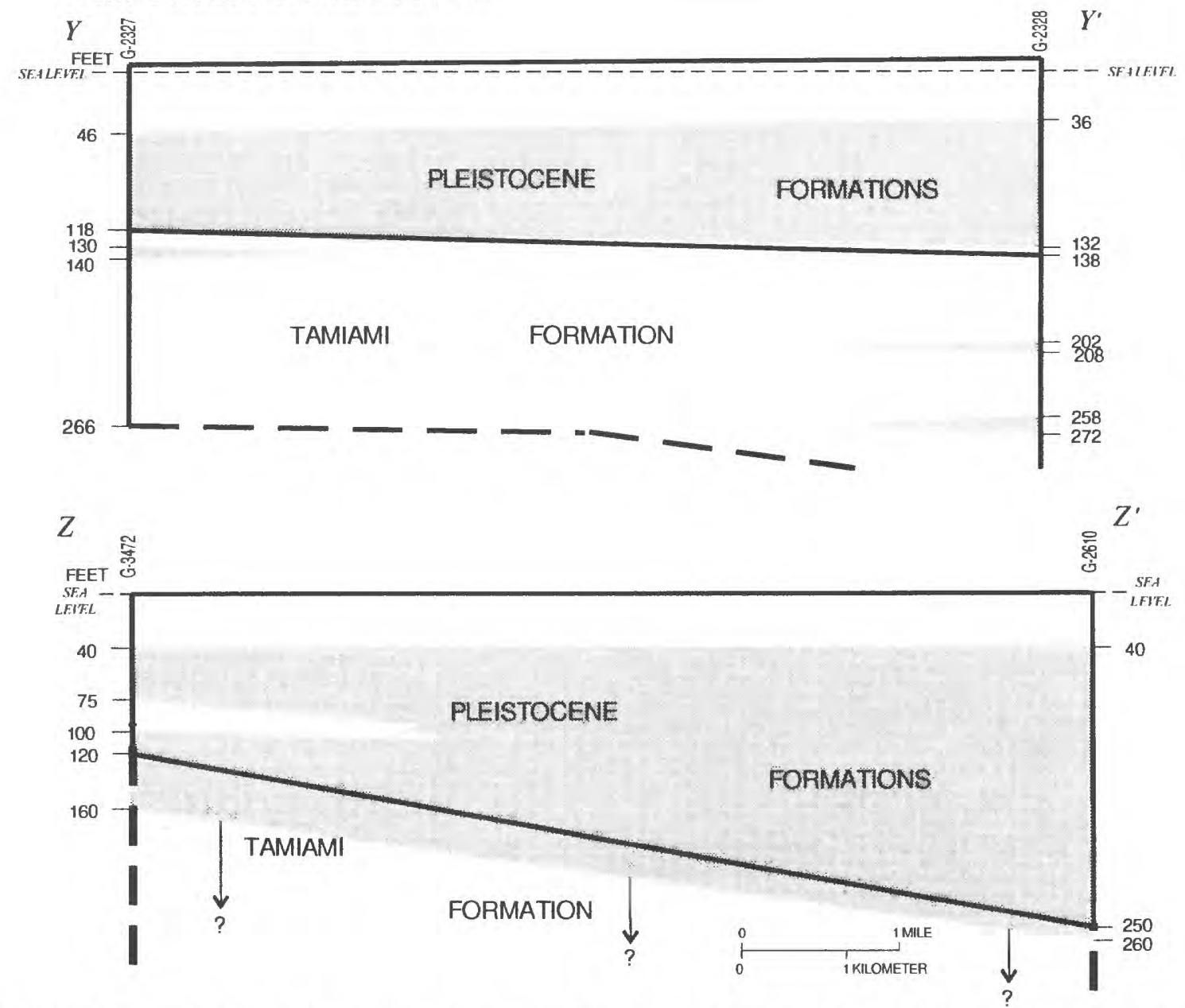

Figure 5. Geologic sections showing estimated thicknesses of formations or formation groups in southeastern Broward County and approximate vertical position of major flow zones. Section $X-X^{\prime}$ and $Y^{\prime} Y^{\prime}$ are modified from Fish (1988). Locations of geologic sections are shown in figure 4. Vertical scale is greatly exaggerated. 
the eastern ends of the sections, the upper part of the aquifer is a highly permeable section of Key Largo Limestone. In section X-X', the base of the aquifer is approximately coincidental with the base of the Anastasia Formation at $92 \mathrm{ft}$ in the westernmost well (G-2322). However, Fish (1988, fig. 17) found considerable permeability to $184 \mathrm{ft}$ within the Tamiami Formation in well G-2345. In the easternmost well (G-2347), permeability is high throughout most of the Tamiami Formation to the top of the Hawthorn Formation at $330 \mathrm{ft}$, so that Tamiami rocks are considered to be part of the Biscayne aquifer in this area (Fish, 1988, p. 55).

In the two wells of section Y-Y' (G-2327 and G-2328), the base of the Biscayne aquifer is approximately coincident with the top of the Tamiami Formation. However, Fish (1988, fig. 18) reported stringers of high permeability at depths of 202 and $258 \mathrm{ft}$ within the Tamiami Formation at G-2328, the eastern well located in the Hallandale Well Field. In late 1981, J.E. Fish and M.L. Merritt examined chip core samples from well G-2328 for evidence of solution porosity. The informal notes prepared, included as part of appendix 3 , are a somewhat subjective and nonquantitative evaluation of the type and degree of solution porosity apparent in the samples. Between 52 and 120 $\mathrm{ft}$, large cavities with smooth surfaces were apparent and were considered characteristic of the main producing zone yielding water to the well field. Apparent solution features also were present in the intervals between 213 and $219 \mathrm{ft}$ and between 258 and $273 \mathrm{ft}$ in the Tamiami Formation, but $132 \mathrm{ft}$ is considered the base of the Biscayne aquifer by Fish (1988) because of the thick underlying sequence of materials of substantially lower permeability.

Solution features characterized most of the thicknesses cored ( 270 and $160 \mathrm{ft}$, respectively) in test holes G-2610 and G-3472 (section Z-Z'). Therefore, the base of the Biscayne aquifer was not determined at these locations. Informal notes on solution porosity prepared by M.L. Merritt and R.S. Reese of the USGS are included in appendix 3 . Two common types of solution porosity noted throughout the section in G-2610 were: (1) solution features lined with a brownish crystalline material in recrystallized coquina, and (2) scattered large solution holes lined with a darkgray material in coarse-grained limestone. Coquina (shell hash) was present in much of the test hole interval, indicating that deposition occurred in a highenergy coastal environment. Some intervals of coquina were not highly recrystallized, were lighter in weight than other sections, and did not exhibit significant solution porosity. The primary porosity of this material might be high but was not measured in this study.
In well G-3472, the two types of solution porosity noted above were augmented by a third type, large solution cavities in fossil coralline material. Significant solution features were nearly continuous with depth below $40 \mathrm{ft}$, the interval from 75 to $100 \mathrm{ft}$ being the only zone of significant thickness not exhibiting such features.

In summary, the base of the Biscayne aquifer is assumed to be coincidental with the top of the Tamiami Formation several miles inland of the present-day coast, and the aquifer extends downward into the Tamiami Formation and appreciably thickens closer to the coast. As previously noted, data describing the vertical extent of the aquifer offshore are lacking. Inland of the coast, the sections of Pamlico Sand and silty, limy sections of the Anastasia Formation lying between land surface and 35 to $50 \mathrm{ft}$ below land surface are assumed on the basis of lithology to be of relatively low permeability, though direct measurements are lacking, and are not considered to be included in the Biscayne aquifer. The top of the Biscayne aquifer, therefore, is considered to lie below this surficial layer of sand, as previously noted. In the study area, the frequent, intense rainfall recharges the Biscayne aquifer by leaking downward through these materials of presumed lower permeability.

Fish (1988, fig. 38) estimates the transmissivity of the Biscayne aquifer to be greater than $1,000,000$ $\mathrm{ft}^{2} / \mathrm{d}$ (feet squared per day) east of Highway I-95 (fig. 4), an area that includes the locations of wells G-2347, G-2328, and G-3472, where sections of the highly permeable Key Largo Limestone are present. In the study area west of I-95, the estimated transmissivity is between 300,000 and $1,000,000 \mathrm{ft}^{2} / \mathrm{d}$. This implies that the average horizontal hydraulic conductivity of the Biscayne aquifer probably ranges between 7,500 and 10,000 ft/d (feet per day). Estimates of the hydraulic properties of the less-permeable zones overlying and underlying the Biscayne aquifer were not obtained by Fish (1988), it being difficult to separate the hydraulic response to stress in these zones from the response of the adjacent, highly permeable Biscayne aquifer. According to Todd (1980), the hydraulic conductivity of clean sands generally ranges from 10 to $150 \mathrm{ft} / \mathrm{d}$, depending on the grain size.

The Biscayne aquifer and overlying deposits are highly permeable vertically despite the presence of some overlying beds that usually lack evident solution features. Supporting evidence for this conclusion is offered in the form of a comparison of hydrographs from wells G-1472 and G-1473 (fig. 6). Well G-1473, $132 \mathrm{ft}$ deep and cased to $126 \mathrm{ft}$, is located in the center 


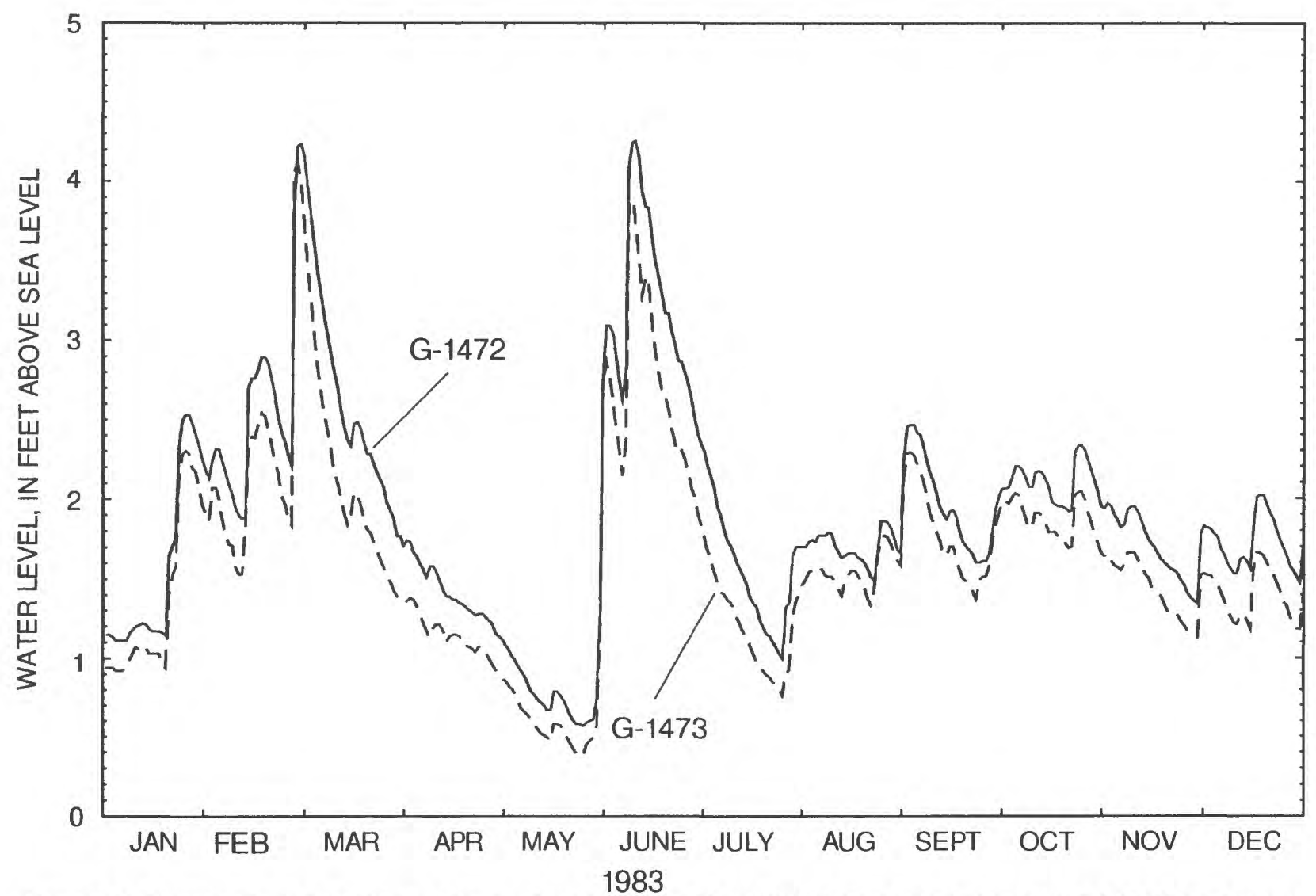

Figure 6. Maximum daily water levels recorded in wells G-1472 (20 feet deep) and G-1473 (132 feet deep) in the Hallandale Well Field in 1983 when pumping rate was near the period-of-record maximum.

of what was, before 1988, the main production area of the Hallandale Well Field, consisting of six wells. Well $\mathrm{G}-1472,20 \mathrm{ft}$ deep and cased to $18 \mathrm{ft}$, is located 0.45 mi east and slightly south of G-1473 in a direction that would be hydraulically downgradient under natural (predevelopment) conditions. Both wells were equipped with water-level recorders from January 1970 to October 1993. The water levels measured in the two wells in 1983, when Hallandale Well Field pumping was near its peak volume (about $5.6 \mathrm{Mgal} / \mathrm{d}$ [million gallons per day]) are depicted in figure 6. Despite being hydraulically upgradient under natural conditions, the water level in $\mathrm{G}-1473$ was 0.1 to $0.5 \mathrm{ft}$ less than the water level in G-1472 throughout the year, probably as a result of the drawdown induced by pumping of the well field. However, water-level changes in the two wells in response to rainfall events and dry periods correlate closely, demonstrating the lack of any appreciable confinement in the vertical interval separating the two wells.

In constructing a model of the ground-water flow system in southern Dade County (Merritt, 1996b), specific yield estimates from rainfall/water-table rise relations were used as an estimate of the effective porosity of the solution-riddled part of the Biscayne aquifer. In aquifers characterized by secondary (or solution) porosity, effective porosity is considered to be the relative volume of connected solution features through which water movement can occur. An effective porosity value of 20 percent was used with success in the Dade County model. A similar estimate was made by Parker and others (1955) and by Appel (1973).

\section{Hydraulic Gradients and Water-Table Altitude Before Development}

Before water management in the study area began with the construction of regional drainage canals in 1907 , the direction of flow in the Biscayne aquifer in inland locations was probably to the east and southeast, except where natural streams, such as New River and Middle River, caused a convergence and upward movement of flow from the aquifer. West of the coastal ridge, the flow direction would have been opposite the land-surface slope because land-surface elevation generally decreases westward toward the Everglades. The eastward flow direction was maintained by the high stages of surface water that 
occurred in the Everglades during most of the year, stages that were probably significantly higher than occur today.

The conventional view is that ground-water flow in the study area continues eastward until reaching tidewater at discharge locations, possibly located offshore in shallow water or at the edge of the Atlantic Shelf 2 to $3 \mathrm{mi}$ offshore. However, there are no known data identifying either current or historical offshore discharge areas near the study area, although Parker and others (1955, p. 581-593) document reports of freshwater discharge to Biscayne Bay farther south. An alternative hypothesis is that flow in the Biscayne aquifer near the coast parallels the coast, possibly blocked from discharging to tidewater by a horizontal facies change in the aquifer where the aquifer material becomes relatively impermeable, or where the aquifer material lacks solution porosity or has had solution porosity reduced as a consequence of the infilling of cavities by other materials. Again, there are no known data to verify or refute this hypothesis. Because borehole data offshore are not available in the study area and because aquifer-head variations near the coast are poorly defined by data from the few observation wells, the actual locations and mechanisms of ground-water discharge are unknown.

The approximate extent of land formerly inundated during most of the year and land formerly inundated for shorter periods can be generally inferred from a consideration of the distribution of surface soils (Pendleton and others, 1984). Areas having the greatest degree of inundation are marked by the deposit of organic soils on the surface. In southeastern Broward County, these soils generally occur west of I-75 (fig. 7) though they extend east of Flamingo Road in an area north and south of Hollywood Boulevard. Using the nomenclature of the U.S. Department of Agriculture, Soil Conservation Service (Pendleton and others, 1984), these soils include the Dania, Lauderhill, Plantation, and Okeelanta mucks. Areas having lesser degrees of inundation (marginal wetlands) or inundation for shorter periods of time (including former cypress woodlands) are those characterized by poorly drained surface soils that are sandy with a significant degree of organic content. In most of the study area, these soils extend eastward almost to Highway 441 . However, between the North and South New River Canals, these soils extend eastward almost as far as U.S. Highway 1. The soil types are those identified by the Soil Conservation Service as the Basinger, Margate, Immokalee, Pompano, Hallandale, and Boca fine sands and the Hallandale and Margate soils. East of Highway 441 occur the well drained, sandy soils of the coastal ridge. Surface soils east of U.S. Highway 1 are generally fill of artificial origin; the area was once a low-lying coastal wetlands. A description of landsurface elevation in part of the region is shown in figure 7. The data are part of a geographical spatial data base prepared by the USGS (Sonenshein, 1992).

Estimates of predevelopment water-table elevations and their seasonal variation have considerable value as a basis for model construction, but few actual data are known to exist. To formulate a reasonable hypothesis concerning the range of predevelopment water-table altitude in these wetlands and marginal wetlands regions, head data from two stations equipped with water-level recorders in central Dade County were studied. The stations are P-33, a surfacewater site in Shark River Slough, and G-596, a well located in the rocky glades region bordering Shark River Slough on the east side of the slough. Station locations and data are shown by Merritt (1996b, fig. 17 and table 2). The relation of the seasonal head variation to the land-surface elevation at P-33 was considered typical of most of the region characterized by surface deposits of peat or marl in central and southern Dade County, and is assumed for hypothesis to also typify the hydroperiod in the previously inundated region of central Broward County covered by organic soils (fig. 7). The rocky glades region where well G-596 is located is in an area that is occasionally (and only slightly) inundated when overland flow stages in Shark River Slough are exceptionally high. This region is considered generally comparable to the region of central and eastern Broward County where poorly drained sandy surface soils with some organic content are present (fig. 7), and it is assumed for hypothesis that the relation of the seasonal head variation to the land-surface elevation at G-596 is also representative of predevelopment conditions in this region of Broward County.

Heads at P-33 and G-596 during water years 1953-61 (fig. 8) are studied because heads at these sites during this period are relatively unaffected by drainage canals and water-management operations (Merritt, 1996b). Time-period average monthly heads for each site were determined from the record available. The time-period averages were computed as the average over a period of years of the average heads for each month of the year and depict the average seasonal head variation for the time period.

Well G-596 is located near the southern end of the section of Levee $31 \mathrm{~N}$ and borrow canal that existed at the time, but a simulation of ground-water flow by the author (Merritt, 1996b) indicated that the only effect of the borrow canal on water levels in the 


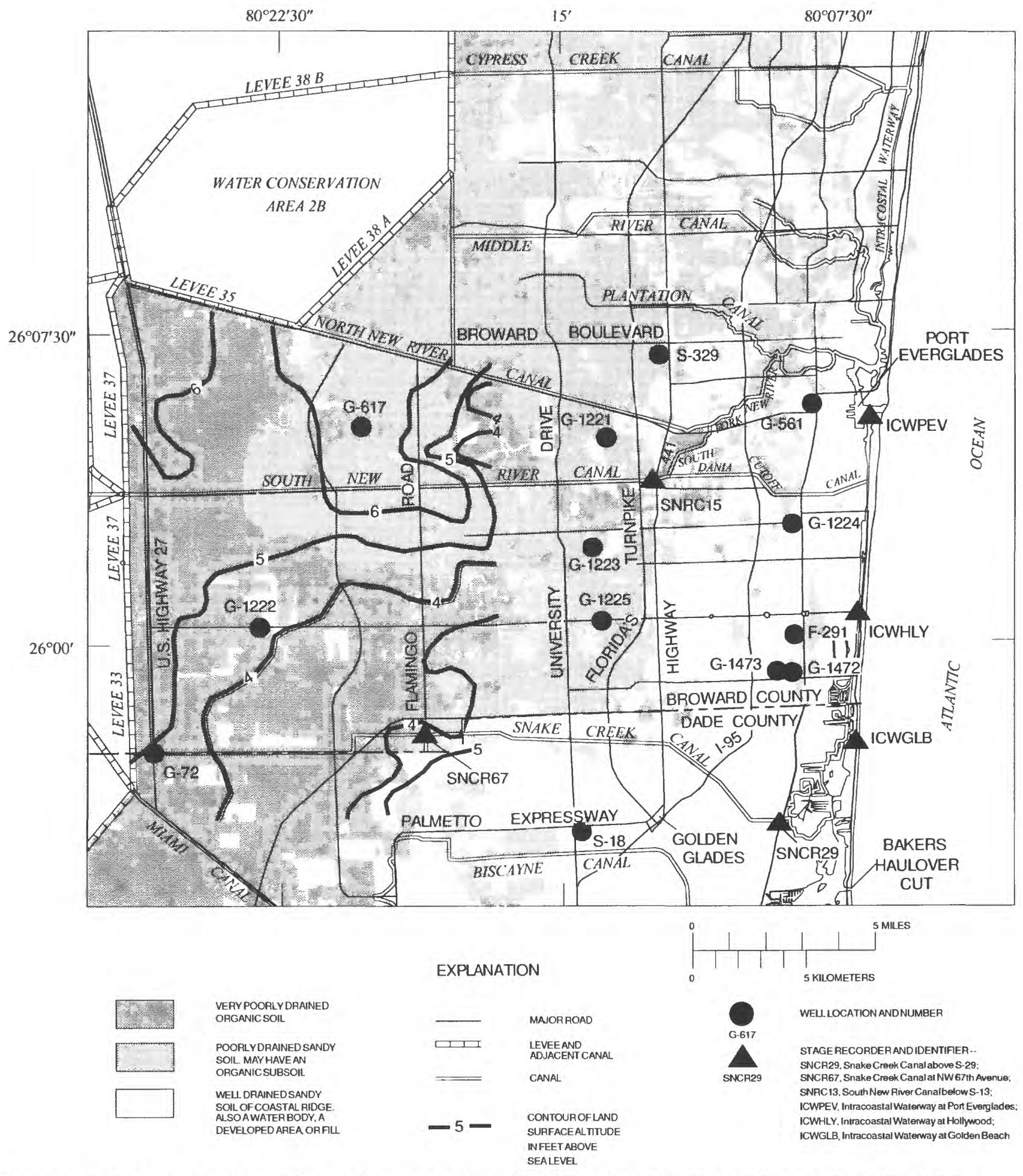

Figure 7. Major soils regions in the study area and locations of wells and gaging stations used for analysis of the effect of the north-south levee and canal system on the water-table altitude. Modified from Pendleton and others (1984). Land elevations are generalized from a spatial data coverage described in Sonenshein (1992, p. 30). 


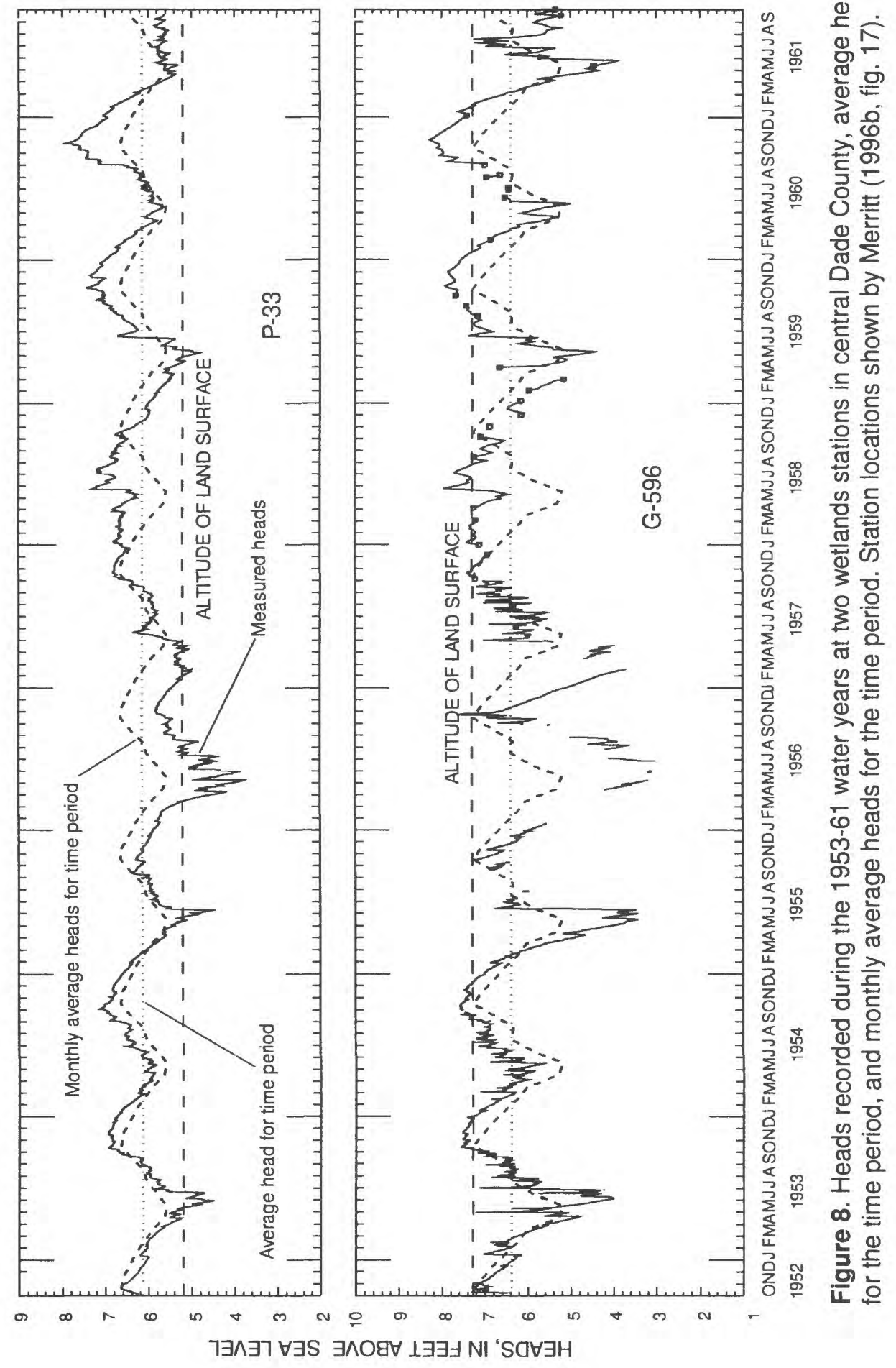


well was to raise dry-season levels by no more than $0.6 \mathrm{ft}$. The effect of the borrow canal on water levels in the well was indicated to be negligible when the water level approached land surface during the wet season. The assumption that heads from P-33 and G-596 represented nearly natural conditions before 1962 implies that the Tamiami Trail did not restrict southward surface-water flow. Before 1962, numerous culverts through the road bank permitted the southward flow of surface water past the road. These culverts were connected on the upstream (northern) side by a shallow, generally nonarterial, borrow ditch. Assuming heads at P-33 and G-596 to represent natural conditions must also be qualified with the reservation that the effect of post-1907 Everglades drainage on the hydroperiod in this region is not fully known, though likely minimal.

At wetlands station P-33, the average stage varied seasonally from 0.4 to $1.4 \mathrm{ft}$ above land surface between 1953 and 1961, and the average annual stage was about $1 \mathrm{ft}$ above land surface. At well G-596 in the marginal wetlands, the average water level varied seasonally from $2 \mathrm{ft}$ below land surface to land surface in this period, and the average annual water level was $0.8 \mathrm{ft}$ below land surface. The heads at P-33 can be compared to heads recorded at well G-72 on the border between Dade and Broward Counties (fig. 7) during the 1940-56 water years, before the north-south levee was completed. Well G-72 is the only known station in the organic soils region of Broward County to have provided data before construction of the northsouth levee. However, G-72 was located at the southern end of the Highway 27 borrow canal, and water levels in the well could have been raised or lowered by its influence. The Miami Canal was $1.4 \mathrm{mi}$ away from G-72 and its influence might have lowered the water level in the well. Regardless of these probable or possible influences, average wet-season water levels at G-72 (fig. 9) were well above land surface ( $5 \mathrm{ft}$ ) during this period. A high of $9.4 \mathrm{ft}$ above sea level was recorded after the hurricane of October 1947. The average seasonal water-level variation was from $1.2 \mathrm{ft}$ below land surface to $1.6 \mathrm{ft}$ above land surface. The average annual water level in this period was $5.33 \mathrm{ft}$ above sea level, about $0.33 \mathrm{ft}$ above land surface. The upper limit of the average seasonal range of water levels is even higher above land surface than the upper limit of head at P-33. However, the lower limit of the annual range of head is well below land surface, unlike the situation at P-33, and the annual average is closer to land surface. Whether these differences are the result of drainage by the Miami Canal and the Highway 27 borrow canal cannot be determined from available data.
Well G-617 is the only known station in the poorly drained sandy soils region of east-central Broward County (fig. 7) with records of water levels before completion of the north-south levee in 1956. Between 1951 and 1956, the average seasonal waterlevel variation was from 2.25 to $0.70 \mathrm{ft}$ below land surface (fig. 9), and the average annual water level was $4.34 \mathrm{ft}$ above sea level, or $1.66 \mathrm{ft}$ below land surface. The lower limit of the range with respect to land surface is similar to that occurred at G-596 between 1953 and 1961, particularly when the effect of the levee $31 \mathrm{~N}$ borrow canal in raising dry-season water levels in G-596 is taken into account. However, average monthly water levels were as high as land surface at G-596, which did not occur at G-617. Again, whether the early drainage system is responsible for the difference in the upper ranges of average water levels cannot be determined from existing data.

The evidence cited does not make a compelling case for assuming that predevelopment heads had a different seasonal range at the locations of G-72 and G-617 than that shown by the hydrographs of pre1957 data (fig. 9). However, if it is assumed that predevelopment heads in the organic soils region and the poorly drained sandy soils regions of southeastern Broward County had seasonal ranges that related to land-surface elevation in a manner similar to that observed at P-33 and G-596 between 1953 and 1961, then the predevelopment head ranges probably would be somewhat higher. The average head range at G-72 might have been from about 5.5 to $6.5 \mathrm{ft}$ above sea level, and the annual average might have been about 6 $\mathrm{ft}$ above sea level. The average head range at G-617 might have been from 4 to $6 \mathrm{ft}$ above sea level, and the average might have been about $5 \mathrm{ft}$ above sea level.

It would also be useful to estimate predevelopment head averages at the locations of wells G-1223 and G-1225 (fig. 7) because these wells between University Drive and Highway 441 are near a location that might be selected as the western boundary of a flow model. Land-surface altitude in most of the region between the South New River Canal and the Snake Creek Canal is between 5 and $7 \mathrm{ft}$ above sea level, although an eastern section around Hollywood Boulevard locally has elevations as high as $10 \mathrm{ft}$ that might be partly artificial. Based on the analogy with G-596 water-level data, an average range of 4 to $6 \mathrm{ft}$ above sea level and an annual average of $5 \mathrm{ft}$ might be reasonable estimates of predevelopment heads in this area. If it were accepted that average 1953-61 heads at P-33 and G-596 were underestimates of predevelopment heads at those station locations, then even higher estimates of predevelopment heads between University Drive and Highway 441 could be justified. 

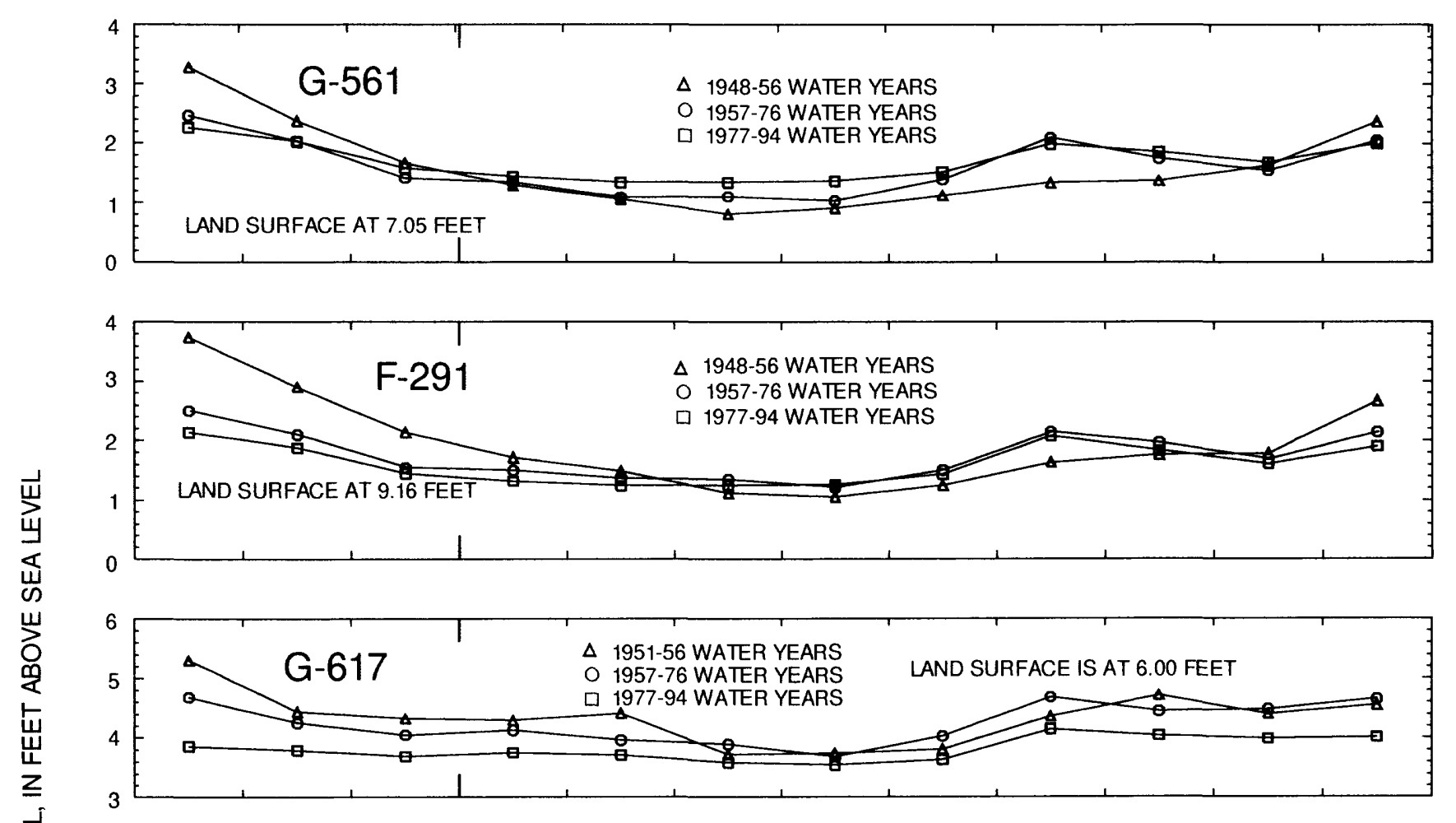

$\frac{\frac{1}{4}}{\frac{\pi}{4}}$
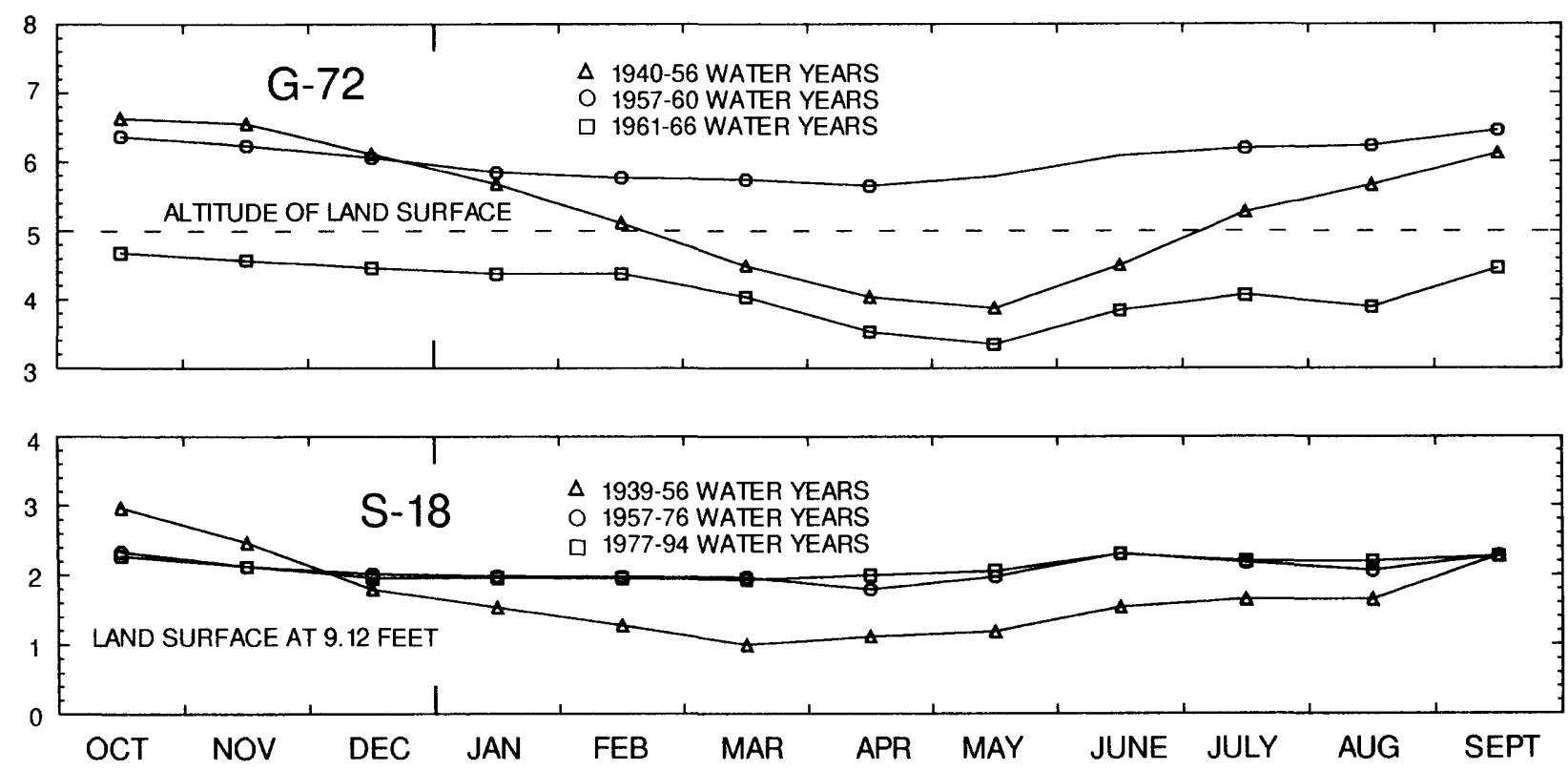

Figure 9. Monthly long-term average water levels in five selected wells before and after completion of the north-south levee in 1956 . Well locations shown in figure 7. 


\section{Development of the Water-Management System in Southern Coastal Broward County}

In 1907, dredging began in the New River Basin as part of the construction of one of the regional drainage canals, the North New River Canal. Construction began a few years later on other regional drainage canals that pass to the north and south of the study area, the Hillsborough Canal and the Miami Canal (fig. 1). The North New River Canal was completed by 1913, at which time Sewell Lock was in operation. Canal construction continued into the 1920's. According to Parker and others (1955, p. 334), the four major drainage canals "were never completed as designed and were inadequate for the flood load imposed on them," and the ability to effectively drain Lake Okeechobee was only achieved in the late 1920's by gradual improvements to the Caloosahatchee Canal and the dredging of the St. Lucie Canal. Though not highly effective as a means of draining Lake Okeechobee, the four drainage canals reaching the southeast coast had a major influence on the groundwater table and the conversion of marginal wetlands to economically useful land along the coastal ridge. Parker and others $(1955$, p. 171) report that the canal construction had "effectively lowered the average height of the water table" in the area of Fort Lauderdale and Dania. The effect on the water table was probably greatest in the regions immediately adjacent to the major canals.

In the vicinity of the study area (figs. 1 and 2), additional construction as part of the 1905-28 drainage program included the South New River Canal (C-11), which was completed westward from the South Fork New River to the Miami Canal, and the Dania Cutoff Canal. A section of the South New River Canal east of levee 37 was improved (widened and deepened) in 1953 as part of the Central and Southern Florida Flood Control Project authorized by an act of the U.S. Congress in 1948. Pumping station S-13 was completed in November 1954, control structure S-13A was completed in October 1956, and pumping station S-9 was completed in April 1957. The Snake Creek Canal (C-9) (the lower part of which has also been known as "Royal Glades Canal"), which ended to the west at the Flamingo Road Borrow Canal, was completed in 1912-13. Sections of the canal were widened and deepened during 1952-54 and control structure S-29 was added by November 1953. Snake Creek Canal was extended westward to L-33 by November 1960 , when control structure S-30 was completed.

Hollywood and Spur Canals (C-10) apparently existed as shallow (5 to $6 \mathrm{ft}$ deep) ditches when the flood-control project was enacted in 1948, and were improved by February 1962. The Biscayne Canal (C-8) in Dade County (fig. 2) was constructed in 192526. North of the study area, the Pompano Canal was also part of the 1905-28 construction, and the Plantation and Middle River Canals probably existed as shallow ditches when the flood control plan was enacted in 1948. The Middle River and Plantation Canals (C-13 and C-12) were improved by 1954. By August 1961, the Pompano Canal had been improved and the Cypress Creek Canal (C-14) had been constructed with control structures S-37A and S-37B. The West Holloway Canal (C-42) was completed by August 1950.

Before 1950, the roadbed of U.S. Highway 27 was used as a north-south levee, which proved ineffective during the 1947 flood. Highway 27 dammed the South New River Canal where they intersected. As part of the Central and Southern Florida Flood Control Project, a new "north-south levee" was constructed from 1950-52. The principal purpose of this levee was to protect urban lands near the coast from receiving floodwaters from the Everglades during periods of high rainfall as occurred in the autumn of 1947 and to enclose the "water-conservation areas" created by the Everglades Drainage District by 1947. Sections of this levee near the study area include, from north to south, levees $36,35 \mathrm{~A}, 35,37,33$, and 30 (fig. 2). The waterconservation areas were west of the levees. Levee 35B divided and allowed a stage separation between Water Conservation Areas 2A and 2B. Water Conservation Area $3 \mathrm{~A}$ is west of the northern part of levee 37 , and Water Conservation Area 3B is west of the southern part of levee 37 and west of levees 33 and 30.

The levees maintain a substantial head difference between the usually inundated water-conservation areas and protected lands to the east throughout the year. Fish (1988) reported that average stages of ponded water in Water Conservation Area 2A ranged from $11 \mathrm{ft}$ in the dry season to $13 \mathrm{ft}$ in the wet season. Contemporaneous average water-table altitudes east of levee 36 ranged from 7 to $9 \mathrm{ft}$. In Water Conservation Area $2 \mathrm{~B}$, stages of ponded water ranged seasonally from 9 to $11 \mathrm{ft}$. Water-table altitudes east of levees 35 and $35 \mathrm{~A}$ remained near $5 \mathrm{ft}$. In Water Conservation Area $3 \mathrm{~A}$, stages ranged seasonally from 9 to $10 \mathrm{ft}$, but east of the enclosing levee, water-table altitudes remained near $4 \mathrm{ft}$. In Water Conservation Area 3B, average stages ranged seasonally from 8 to $10 \mathrm{ft}$, whereas water-table altitudes east of the enclosing levees ranged from 3 to $4 \mathrm{ft}$.

Most of the present water-management system was in place by the late 1960 's, following the 
construction of the many control structures (fig. 2), including culverts with risers and stop logs, gated culverts, gated spillways, and pump stations. The focus of water management turned to the sophisticated allocation of quantities of water for a variety of purposes. The water-management objectives that can be accomplished with the present system include:

- Stages in the borrow canals of the north-south levee are maintained sufficiently high to reduce underseepage from the water-conservation areas,

- Water is supplied to the eastern canal reaches in times of low rainfall to replenish well fields and to prevent saltwater intrusion near the coast,

- Water from the water-conservation areas can be flushed to the ocean when stages in the water-conservation areas become excessive,

- Water can be pumped from the canal network into the water-conservation areas or to the ocean to reduce flooding in urban areas during periods of high rainfall, and

- Water can be released from one basin (as defined by local managers in southern Florida) to another when needed.

\section{Effect of Water-Management Controls on the Altitude of the Water Table}

The design and operational use of the current water-management system likely affects typical watertable altitudes in the study area. In this study, these effects are estimated by comparing hydrographs of water levels in wells in the region from periods before and after the main pumping stations and control structures were added between 1952 and 1957. The ability to do so is hampered by the paucity of daily waterlevel records from before 1956 at wells that also provided data from 1956 and afterward. The locations of the five wells providing such record (F-291, G-72, G-561, G-617, and S-18) are shown in figure 7. As before, time-period average monthly water levels were determined from the record available from these stations (fig. 9). The time periods used for the comparison varied slightly depending on the record available at each well, but generally were from the beginning of record to 1956, 1957-76, and 1977-94 water years. There seems to be a slight general decline in the water table after 1977, probably as a result of changes in water-management practices. Five additional wells (G-1221, G-1222, G-1223, G-1224, and G-1225) provide data records for an analysis of post-1961 water levels. Table 1 lists the average seasonal range of water levels and the average annual water level in successive periods of time at these and other selected wells in the study area.
Before 1956, average wet-season water levels at well G-72, where water levels have been recorded since 1940, exceeded $6.5 \mathrm{ft}$ above sea level, which was more than $1 \mathrm{ft}$ above land surface. However, average dry-season water levels were well below land surface. Dry-season water levels were greatly increased for 4 years after 1956, so that the average water level was above land surface all year. In 1960, a section of Snake Creek Canal that passed close to the well was completed westward to levee 33 . This greatly lowered water levels in the well. No longer useful as a regional monitoring well, the operation of the recorder was discontinued in 1966. Well G-1222 has been used as a regional monitoring well in the organic soils region since 1963. Located about $4.2 \mathrm{mi}$ northeast of G-72 and away from drainage canals, average water levels in well G-1222 (fig. 10) varied seasonally and ranged from 2.3 to $0.7 \mathrm{ft}$ below land surface between 1963 and 1976. Water-management changes after 1976 had little effect on water levels in G-1222, except during the dry-season months of February to May, when average water levels appeared to increase.

Long-term hydrographs from three of the five wells used for early time-period comparisons (F-291, G-561, and G-617) and one other well (S-329) providing pre-1956 data are presented by Beaven (1979). As shown in Beaven's hydrographs for wells F-291, G-561, and S-329, the rate of recession from the annual seasonal high was significantly more rapid after 1956. The apparent differences shown by Beaven are clarified by a consideration of the time-period average water levels (fig. 9). The rapid recessions shown by Beaven (1979) are not apparent in these hydrographs but contribute to the lower averages shown for the early recession period. At G-617 where water levels have been recorded since 1951, use of the north-south levee and the various canals and control structures to rapidly lower the water-table altitude at the end of the wet season had the effect of lowering the average water level in October and for several months following during the recession period. The seasonal high occurred in October before 1957, but equal highs occurred in June and October in the 195776 time period, as the late wet-season high was apparently reduced as an objective of water-management policy. The annual average water level was reduced by only $0.1 \mathrm{ft}$, to $4.2 \mathrm{ft}$ (table 1). After 1976, changes in water-management practice lowered water levels in G-617 still further, particularly during the wet season, and the annual average was reduced an additional 0.4 $\mathrm{ft}$. After 1976, the average seasonal high occurred in June, the first month of the wet season. 


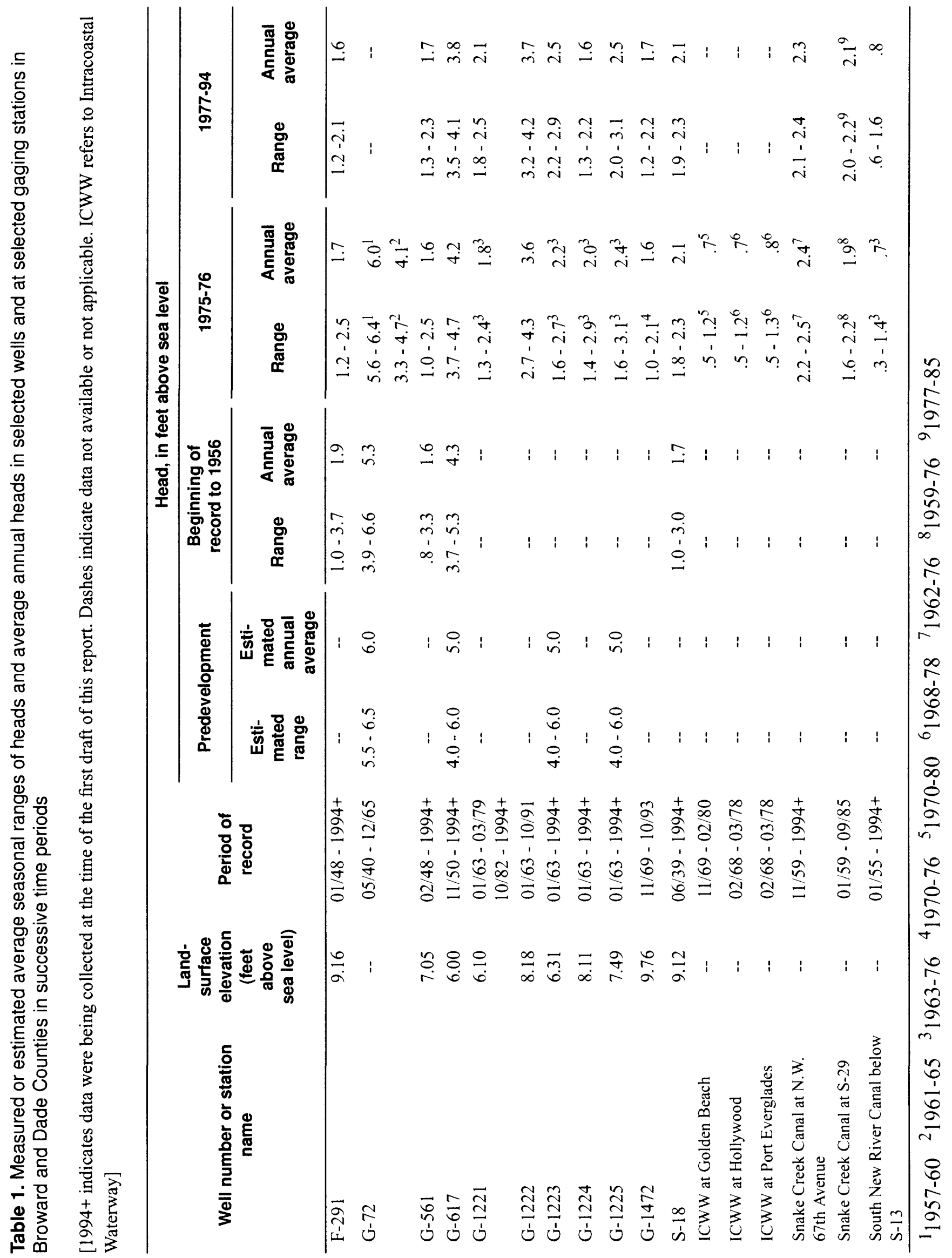



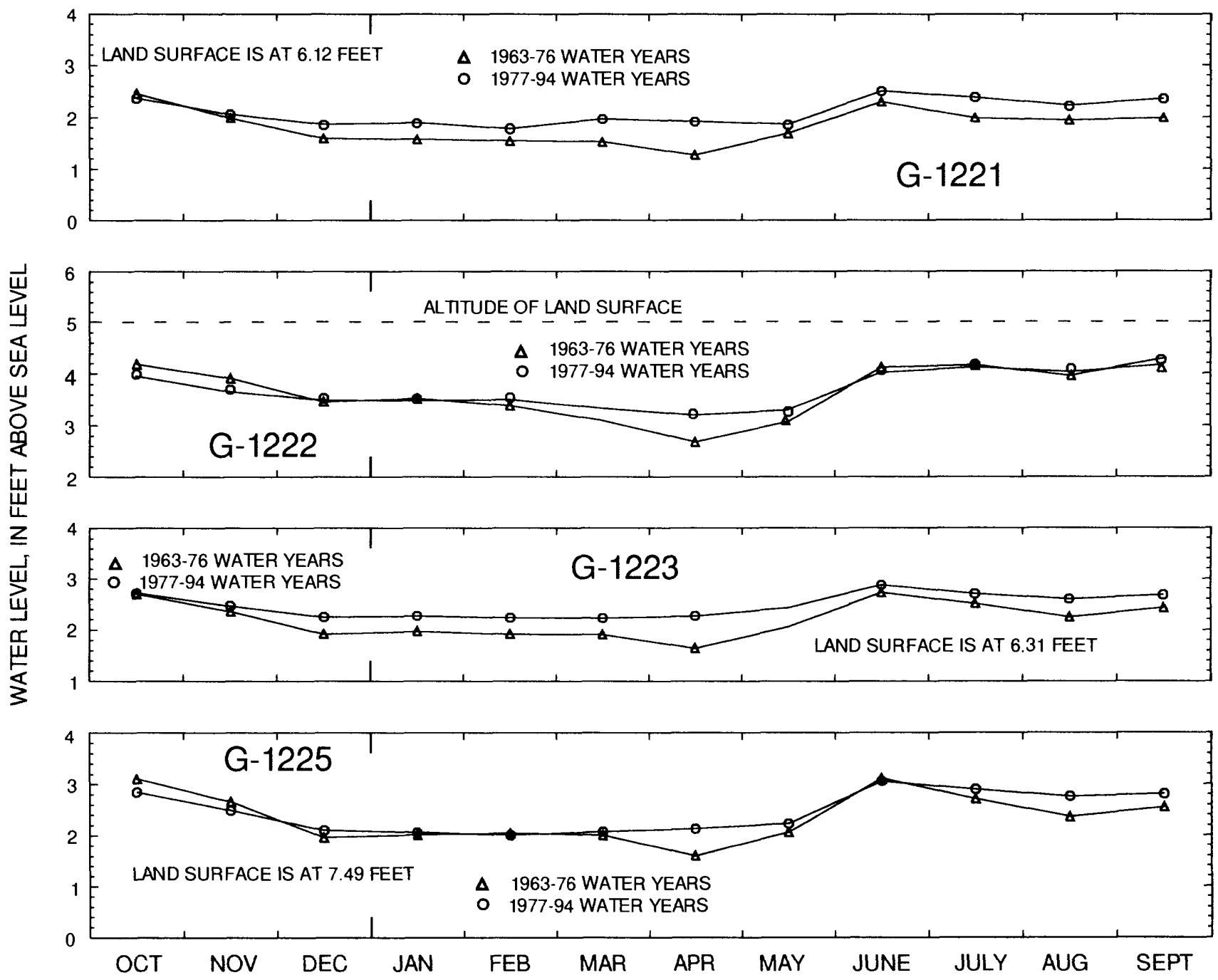

Figure 10. Monthly long-term average water levels in four selected wells showing the average water-table altitude in central and eastern Broward County after 1963. Well locations shown in figure 7. 
Average water levels from well S-329 in different time periods could not be compared because the S-329 water level showed a steady long-term decline caused by the increasing rate of pumping from supply wells of the nearby Dixie Well Field owned by the City of Fort Lauderdale. At coastal ridge wells G-561 and F-291, where water levels have been recorded since 1948, one result of using the levee and canal system for water management was to significantly decrease the rate of seasonal variation in the altitude of the water table as evidenced in average well water levels (fig. 9). Wet-season average highs (September-November) were reduced and dry-season water levels between March and July were increased. However, the annual average at G-561 remained the same, and the annual average at F-291 only decreased by $0.2 \mathrm{ft}$ (table 1 ). After 1976, only slight changes in monthly average water levels occurred at these sites. Neither of the coastal wells was located sufficiently near a well field to be influenced by pumping, or near any drainage canals or control structures that were of recent construction.

Wells G-1221, G-1223, and G-1225 are located near the small well fields of Davie and Pembroke Pines, but water levels at these wells do not show steady long-term declines that would indicate the effect of increasing withdrawals and are probably not influenced by the well fields. Average monthly water levels in G-1223 and G-1225 had ranges of 1.1 and 1.5 $\mathrm{ft}$ during the 1957-76 time period (table 1), but the ranges were reduced to 0.7 and $1.1 \mathrm{ft}$ after 1976 as the water levels increased during much of the year (fig. 10). The annual averages were raised slightly to $2.5 \mathrm{ft}$ after 1976, which contrasts with the predevelopment estimate of nearly $5 \mathrm{ft}$. Well G-1224 is located near the original Davie Well Field, where pumping ceased in 1976. However, peak and average water levels decreased significantly after 1976 (table 1). Water levels from well G-1472, east of the Hallandale Well Field, did not show significant effects from well-field pumping. The average water level did not change appreciably after 1976 (table 1). Time-period monthly averages were also computed for G-1221 (fig. 10), which lies north of the Dania Cutoff Canal. The seasonal range of monthly averages (table 1) is the same as for G-1223 in both the 1957-76 and 1977-94 time periods, but the annual average is less by $0.4 \mathrm{ft}$.

Time-period averages were also computed at well S-1 8 in Dade County (fig. 7) where water levels had been recorded since 1939. S-18 is south of the Snake Creek Canal. Again, the effect of the use of the northsouth levee was to greatly reduce the seasonal variation of water levels in the well (fig. 9). The annual average increased by $0.4 \mathrm{ft}$ after 1956 (table 1). Average water levels after 1976 were almost the same as those of the 1957-76 time period. The seasonal range and annual mean were somewhat lower than those based on water levels measured at well G-1225 farther north.

The approximately uniform stage in the tidal reach of the South New River Canal has been measured since 1963 at a gaging station just below pumping station $\mathrm{S}-13$ (fig. 7, SNRC 13). The average monthly stage has varied seasonally and ranged from 0.3 to $1.6 \mathrm{ft}$ above sea level, and the average annual stage increased from $0.7 \mathrm{ft}$ above sea level before 1976 to $0.8 \mathrm{ft}$ afterward (table 1). Since 1963, the average seasonal high has been in October and the average seasonal low has been in April. The range of measured stage, its seasonal variation, and the annual average are identical to those measured between 1968 and 1978 at tidal stage stations located along the Intracoastal Waterway at Port Everglades (fig. 7, ICWPEV) and Hollywood (fig. 7, ICWHLY) and between 1970 and 1980 at Golden Beach (fig. 7, ICWGLB). Tidal stages were recorded as daily tidal highs and tidal lows. Statistical summaries were prepared for this study by taking the average of each average monthly low and the corresponding average monthly high. The altitude of the annual average tidal stages $(0.7$ to $0.8 \mathrm{ft}$ above sea level) and the wet- and dry-season correlation of average tidal stages (table 1) are remarkable because the Port Everglades site is only $200 \mathrm{ft}$ south of the shipping channel that leads through the barrier island to the Atlantic Ocean. The Golden Beach site is only $4.5 \mathrm{mi}$ north of Bakers Haulover Cut, another open channel to the ocean. This suggests that average sea level offshore may have a similar annual average and show similar seasonal variations.

Stages in the Snake Creek Canal are nontidal because of the presence of a salinity-control structure (fig. 2, S-29) just east of U.S. Highway 1. The stage has been measured above S-29 (fig. 7, SNCR29) since 1959, and at NW 67th Avenue (fig. 7, SNCR67) since 1962. Before 1976 , average monthly stages varied 0.3 to $0.6 \mathrm{ft}$ annually (table 1 ), but the variation did not correlate strongly with wet and dry seasons. The average annual stage differed by $0.5 \mathrm{ft}$ between the stations. After 1976, the annual variation of monthly averages was less (between 0.2 and $0.3 \mathrm{ft}$ ) and the annual average stage differed between stations by only $0.2 \mathrm{ft}$.

The foregoing descriptions of well water levels and canal and tidal stages will be used as a guide for the assignment of boundary conditions for models of the saltwater interface position in predevelopment 
times and in various periods during the era of water management. Generally, the regional water-table altitude does not seem to have changed appreciably since measurements began in 1939, although the seasonal variation in many parts of the region was somewhat reduced after 1956. However, average predevelopment water-table altitudes might have been as much as 1.0 to $2.5 \mathrm{ft}$ higher than those measured since 1939 . A reasonable speculation is that the greatest difference between predevelopment and measured altitudes occurs not in the wetlands, but in the former marginal wetlands just west of the coastal ridge. This would be reasonable if higher stages in the wetlands caused longer periods of flooding in the marginal wetlands, during which times the stage in the flooded regions would have been more uniform than the altitude of the ground-water table when the region was dry.

\section{Public-Supply Wells}

Within the study area (fig. 1), the well fields that are sufficiently close to the ocean that they might induce saltwater intrusion or become contaminated as a result of saltwater intrusion are those located east of Highway 441 (fig. 2). These include well fields suppling water to the Cities of Hollywood, Dania, and Hallandale in Broward County, the Cities of North Miami Beach and North Miami in Dade County, and two well fields (3A and 3B) operated by Broward County. All of these well fields pump water from the Biscayne aquifer.

The Hollywood Well Field is the largest well field located east of Highway 441 within the study area. The first three wells were drilled in 1932 and 1933, and a fourth was drilled in 1940. In 1988, 23 wells were in operation. Of these, 17 withdrew water from a depth interval of 50 to $80 \mathrm{ft}$ below land surface, 4 withdrew water from an interval of about 110 to $130 \mathrm{ft}$ below land surface, and 2 withdrew water from an interval of about 140 to $150 \mathrm{ft}$ below land surface (Alvarez and Bacon, 1988). In 1993, 27 wells were in operation. In 1964, the well field was pumping an average of $4.64 \mathrm{Mgal} / \mathrm{d}$. By 1978 the average daily pumping rate was $17.05 \mathrm{Mgal} / \mathrm{d}$ and, by 1989 , it was $21.72 \mathrm{Mgal} / \mathrm{d}$.

The Hallandale Well Field (fig. 2) began to supply water in 1952. The open intervals of the eight wells in use in 1988 are between 40 and $110 \mathrm{ft}$ below land surface. Six of the wells are at the water-treatment plant site, a seventh is $0.4 \mathrm{mi}$ north and $0.1 \mathrm{mi}$ west of the water plant, and the eighth is $0.35 \mathrm{mi}$ west of the seventh well. Because saltwater intrusion into the main well field appeared imminent, the City of Hallandale began to obtain water through a pipeline interconnection with the North Miami Beach Well Field in August 1988. Pumping was discontinued at all wells owned by the City of Hallandale except for the eighth well, with the seventh being used occasionally during periods of peak demand. The average rate of pumping from the Hallandale Well Field increased from $0.27 \mathrm{Mgal} / \mathrm{d}$ in 1952 to $5.61 \mathrm{Mgal} / \mathrm{d}$ in 1987 . The average rate decreased to $3.42 \mathrm{Mgal} / \mathrm{d}$ in $1989 \mathrm{after}$ the partial shutdown.

The first two wells in the Dania Well Field were drilled in 1957 at the City's water-treatment plant (fig. 2 ). Two more were drilled there in 1970 , and another two were drilled in a cemetery about $0.7 \mathrm{mi}$ to the south in 1972. An increasing trend in the chloride concentration of water obtained from the wells led to the construction of two wells at a location $1.2 \mathrm{mi}$ west of the water-treatment plant in 1976. At this time, the original six wells were placed in a standby status. Pumping at one of the 1976 wells had to be discontinued in 1988 due to contamination from a local source. The depths of the Dania wells vary from 70 to $120 \mathrm{ft}$. The average pumping rate was about $0.8 \mathrm{Mgal} / \mathrm{d}$ in 1961 and was still low (1.8 Mgal/d), compared to that of the Hollywood and Hallandale Well Fields, in 1974. The average rate decreased to about $1.3 \mathrm{Mgal} / \mathrm{d}$ in 1978 but increased again to $2.24 \mathrm{Mgal} / \mathrm{d}$ in 1989.

Broward County Utilities Well Fields $3 \mathrm{~A}$ and 3B (fig. 2), owned by the Broward County Utilities Department (BCUD), have six and four wells, respectively. The first wells were probably drilled in the 1950's. One well in Broward County Utilities Well field $3 \mathrm{~A}$ is $180 \mathrm{ft}$ deep; the others are no more than 110 $\mathrm{ft}$ deep. The wells in Broward County Utilities Well Field 3B are as deep as $140 \mathrm{ft}$. In 1989, average pumping rates at Broward County Utilities Well Fields $3 \mathrm{~A}$ and $3 \mathrm{~B}$ were 2.93 and $3.74 \mathrm{Mgal} / \mathrm{d}$, respectively.

In northeastern Dade County, the Sunny Isles Well Field, owned by the City of North Miami Beach, and the East Side Well Field, owned by the City of North Miami (fig. 2), were both closed because of saltwater intrusion. The Sunny Isles Well Field started to pump water with increasing chloride concentrations in the late 1960's and was shut down and put on standby in 1972 when the East Drive Well Field was completed and put in operation (R. Coates, North Miami Beach Utilities, oral commun., 1994). In 1977, a contaminant spill near the East Drive Well Field required the shutdown of those wells and a temporary reactivation of ihe Sunny Isles Well Field (H. Kottke, Dade County Departmen: of Environmental Resources Management, oral commun., 1994). In June 1978, the 
East Drive Well Field was placed back ii: service. Most of the wells in the Sunny Isles Well Field have since been plugged and abandoned (R. Coates, oral commun., 1994).

Water samples from wells in the North Miami East Side Well Field began to have increasing chloride concentrations in the late 1960's. During the severe drought of 1971, chloride concentrations higher than $500 \mathrm{mg} / \mathrm{L}$ were reported from some wells (H. Kottke, oral commun., 1994). Increasing chloride concentrations were again reported in 1974, 1975, and 1976. The East Side and West Side Well Fields were both pumped until about 1977, at which time the East Side Well Field was taken out of regular service. A pumping report for the well field with entries ending in October 1982 shows that some pumping continued, but the water-treatment plant was later disassembled.

From a consideration of the depths of the publicsupply wells in the study area, it is concluded that the principal zone of water supply is about 50 to $150 \mathrm{ft}$ below land surface. The lowering of the water table caused by well-field pumping is usually greatest in the dry season because of the coincidence of peak demand with the lowest amount of recharge from rainfall. Because the Biscayne aquifer is so highly permeable within the study area, significant drawdowns from public-supply wells tend to be localized, as indicated by the average dry-season water-table map of Fish (1988, fig. 41).

\section{PROGRESSION OF SALTWATER INTRUSION IN SOUTHERN COASTAL BROWARD COUNTY}

If a body of saltwater lies adjacent to a body of freshwater having its surface at the same altitude, the saltwater, because of its greater weight, will move toward the freshwater, thus displacing it. However, the water-table altitude in coastal surficial aquifers is usually higher than sea level, so that the displacement of fresh ground water by seawater is only partial and an equilibrium position of an interface between the freshwater and saltwater exists. Because, in saltwater, the pressure increase with depth is greater than in freshwater, the equilibrium position of the interface occurs farther inland with depth, and the spatial distribution of the saltwater near the coast resembles a wedge, or "toe," underlying the body of freshwater. In natural coastal systems not modified by urban, industrial, or agricultural activities, seawater and inland freshwater in surficial aquifers normally are close to their equilibrium positions. The position of the interface onty respc ids sligktly to seasonal or episodic climatic variations.

When anthropogenic activities change the watertable altitude in a coastal surficial aquifer, freshwater and saltwater will move toward new equilibrium positions determined by the new water-table altitude. When the water table is lowered by drainage for urban development or by well-field pumping, the interface movement will be inland. When the water table is raised, the interface moves seaward. In southeastern Florida, raising the water-table altitude is often one of the objectives of the construction of canals with salinity-control structures near the coast. However, the construction of canals for salinity control has usually occurred following a previous lowering of the water table by pumping or the use of canals for drainage. One of the principal problems facing water managers in the region has been saltwater encroachment resulting from lowered water tables, particularly when the movement of saltwater is toward a well field.

A related process of saltwater intrusion occurs when tidal canals are constructed that allow seawater to circulate inland when the tidal stage is high and quantities of freshwater runoff and ground-water seepage discharging into the canals are low. In this case, the intrusion of saltwater occurs from the canal cross section near land surface and not from depth, as in the case of the inland movement of the coastal saltwater "toe" described above. Saltwater intruding from the tidal canal inland of the coastal interface may settle to lower levels of the aquifer because saltwater is heavier than freshwater. In some cases, the settling saltwater may be entrained by a highly active flow field in a zone of high permeability and may quickly migrate downgradient in the zone. In some cases, such highly permeable zones are those pumped by well fields.

Coastal saltwater encroachment and tidal canal intrusion may occur together in the same area when a tidal canal transects the coastal saltwater interface. Because the canal is tidal, the lower head near the canal may induce the coastal saltwater interface to move farther inland in the vicinity of the canal than elsewhere. In the study area, a combination of these processes occurs in the vicinity of the Dania Cutoff Canal and the short tidal reach of the South New River Canal (fig. 2) downstream (east) of structure S-13. In the vicinity of the Hollywood and Spur Canals, tidal circulation of saltwater in the canals induces shallow saltwater intrusion into the Biscayne aquifer at locations where freshwater may occur at greater depth.

Where the position of the coastal saltwater interface has reached equilibrium, the chloride and 
dissolved-solids concentrations increase monotonically downward through a "transition zone" of mixed freshwater and saltwater. Where the interface is moving in response to a change in water-table altitude, the movement of saltwater or freshwater can be more rapid in discrete zones of higher permeability than in intermediate semiconfining beds, so that the chloride and dissolved-solids concentrations may decrease downward in some depth intervals. Where saltwater intrusion from a canal occurs, the vertical distribution of chloride and dissolved solids depends upon the volume of saltwater discharged from the canal, local geologic controls, and the mixing effects that occur within the aquifer.

The general structure of the transition zone is qualitatively similar to the one delineated by Kohout (1960, fig. 4; fig. 11 in this report) in the Silver Bluff and Cutler areas of Dade County, where a generally similar lithology exists. The Cutler diagram is based on data from several clusters of wells open to many depths within the aquifer. The concentration gradient appears to be nearly vertical between 40 and $60 \mathrm{ft}$ below sea level and nearly horizontal at depths greater than $70 \mathrm{ft}$ below sea level. Kohout (1960) does not explain the relation of the shape of the interface to geologic control (the vertical sequence of layers of varying permeability). Fish and Stewart (1991, pl. 3) reported layers of high permeability to a depth of about $100 \mathrm{ft}$ below land surface near the site of Kohout's work at Cutler.

The investigation of saltwater intrusion in the Biscayne aquifer of southeastern Florida by the USGS began in 1939 and is divided into two distinct time periods. The early period of data collection that generally ended in 1944-45 was conducted and documented by Parker and others (1955). Many of the well sites in the study area where data were obtained on a regular or sporadic basis in this early period are shown in figure 12. Several sites where a few additional samples were obtained for chloride analysis are not shown in the illustration because the data have little interpretive significance. Samples were collected for chloride analysis from well S-330 at the Dania Florida Power and Light Plant at least through 1947 (Vorhis, 1948), and chloride sampling from well F-279 continued through November 1992 (fig. 13).

In the study area, between Snake Creek and Dania Cutoff Canals, no chloride sampling by the USGS took place during the 1950's. In the early 1960's, sampling for chloride analysis by the USGS consisted of a small number of water samples collected when new wells were drilled or soon afterward. The operation of a network of observation wells began in the autumn of 1967 , and new wells were added to the network throughout the 1970's, 1980's, and early 1990's. Most present chloride observation wells are located in the vicinity of well fields because of the critical importance of the potential effect of saltwater intrusion on public water supply. In the study area, present and former USGS observation well networks have been located near the Hollywood Well Field, Hallandale Well Field, and Broward County Utilities Well Field 3A (fig. 2). In recent years, local agencies have done an increasing share of the monitoring of saltwater intrusion.

Chloride data from the observation well networks are generally inadequate to define the diffuse saltwater interface anywhere in the study area. Therefore, the data considered in subsequent sections will be cited to estimate the position of what is termed the "saltwater front." The saltwater front is considered, for purposes of this report, to be a line eastward (seaward) of which water with a chloride concentration in excess of 250 $\mathrm{mg} / \mathrm{L}$, the secondary maximum level recommended by the U.S. Environmental Protection Agency (1977), occurs at depths generally corresponding to the pumping zones of major well fields in the area $(50-150 \mathrm{ft}$ below land surface). Previous delineations of saltwater-intruded areas have used the concentration of 1,000 $\mathrm{mg} / \mathrm{L}$ of chloride at the base of the Biscayne aquifer as the criterion for establishing the extent of saltwater intrusion (Klein and Waller, 1985). As stated, the criterion used in this study is less precise than that used by Klein and Waller (1985), though closely related. Because chloride samples are from discrete depths at widely scattered locations, and because the well-field pumping zones generally include the entire aquifer thickness, the two criteria should lead to similar results.

The following sections describe the evolution of the monitoring network and results of the collection of water samples that help to define the extent of saltwater intrusion and its variation with time. Depths cited for wells used in the discussion are as reported by owners or as measured by the USGS. Until recently, most wells installed for the purpose of obtaining samples for chloride analysis were percussion-driven, after which the casings were jacked up a short distance. Subsequently, water samples were collected from the usually small interval $(0.5-2.0 \mathrm{ft})$ of disturbed, broken rock at the bottom of the pipe. The casing depths of most of the percussion-driven wells have not been reported, however, and the exact depth intervals to which these wells are open to the formation are rarely known precisely. Frequently, water samples are obtained at various depths for analyses of chloride concentration as the well is driven. 


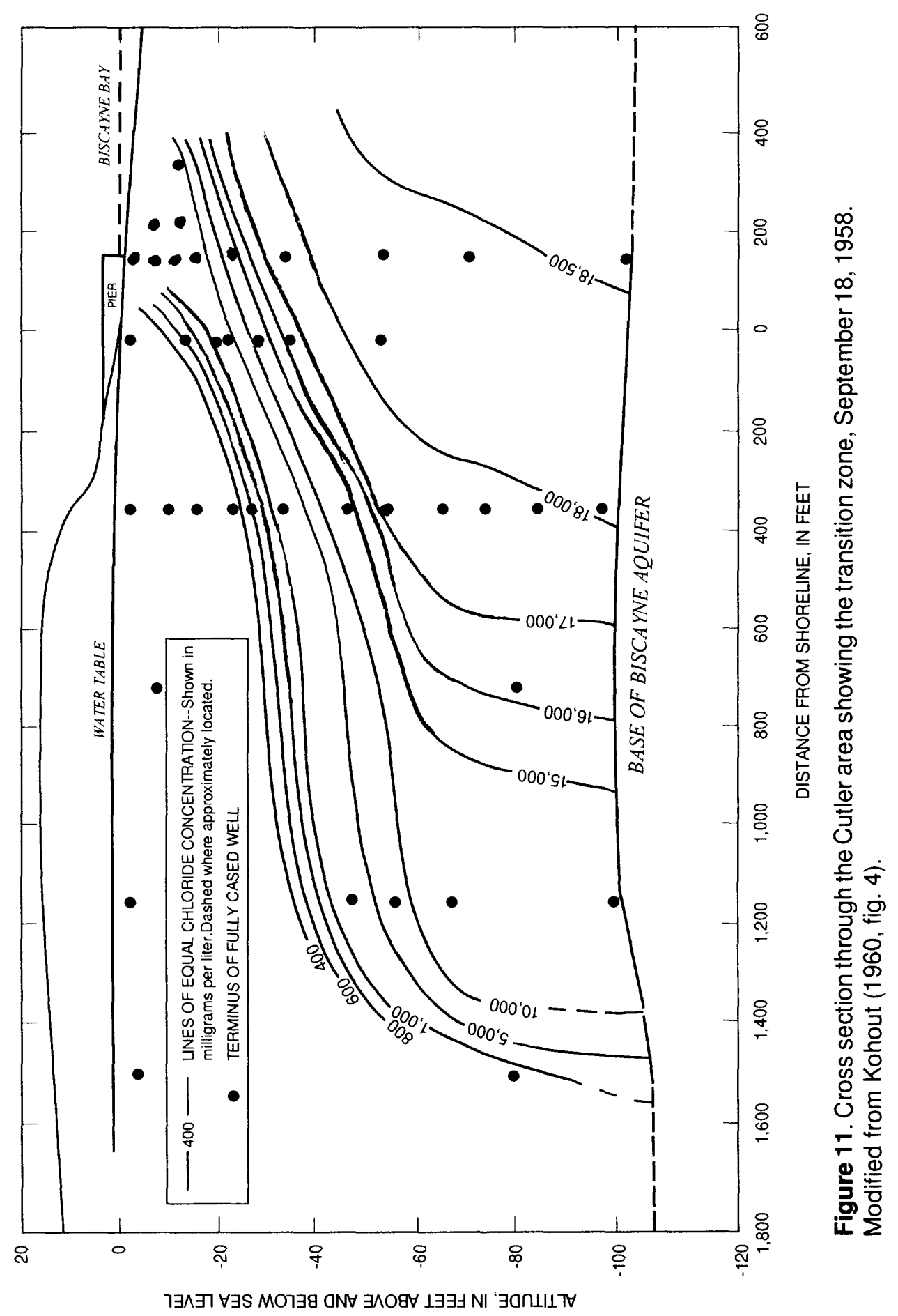




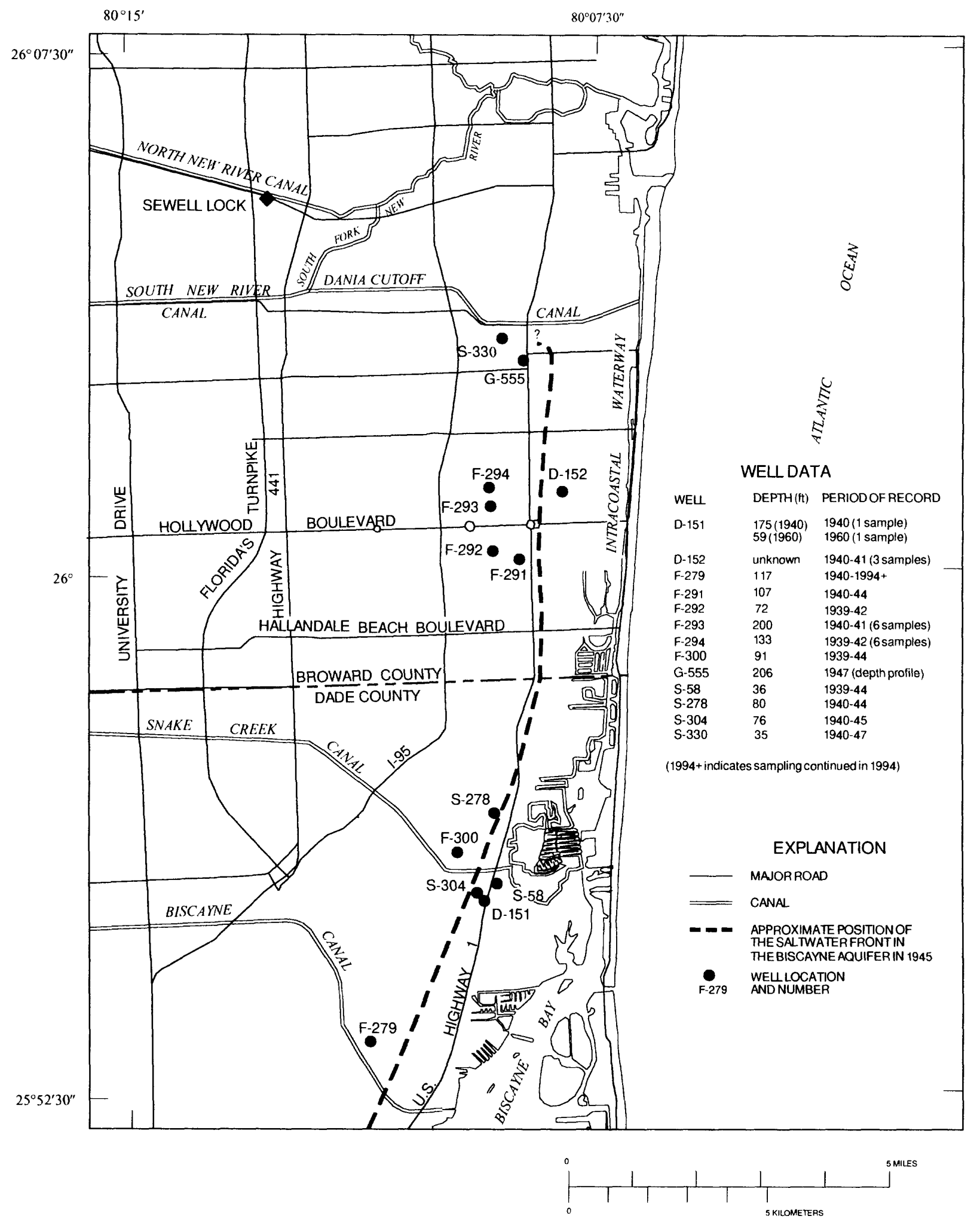

Figure 12. Locations of wells used for detecting and monitoring saltwater intrusion in the 1940's and approximate position of the saltwater front in the pumping zone in 1945. 


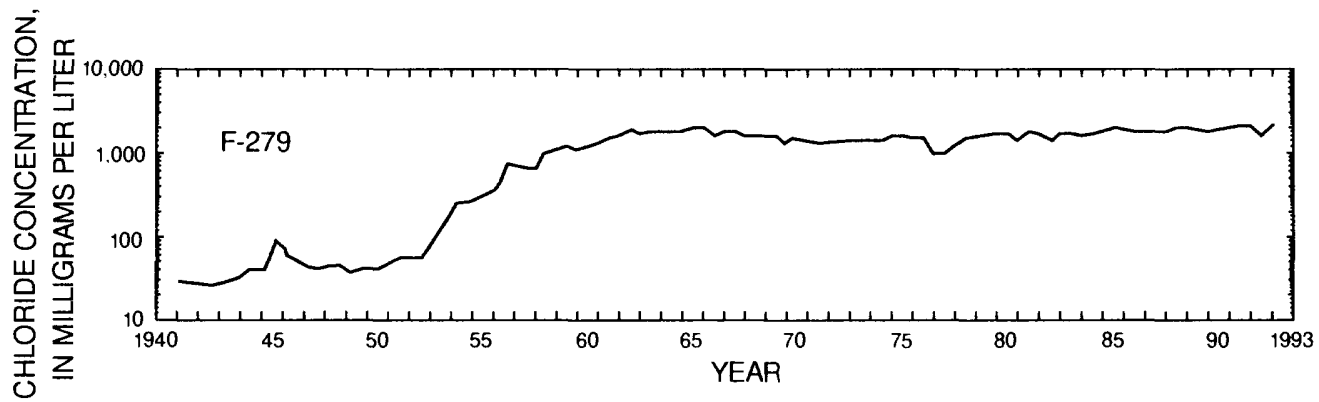

Figure 13. Chloride concentrations of water samples from well F-279, 1940-93. Well location shown in figure 12 .

Since the early 1980 's, a few wells providing chloride data were installed by the dual-tube reverse air method, which also allows for the collection of representative water samples at successive depths. Many of these wells were finished as monitoring wells by the subsequent installation of casing.

The chloride data used in the following sections to estimate the position of the saltwater front is presented in several hydrographs and in table 2. Except for several samples from the 1940's that do not provide useful information, the data set is an exhaustive and complete presentation of the USGS data base available at the time of the preparation of this report (1994). Where an extensive time history of chloride analyses that clearly defines trends over time is available from a particular well, the data are shown in hydrograph form. Where only one or several samples are available that are closely or widely spaced in time, they are listed in table 2. Depth profiles obtained from percussion-driven or dual-tube reverse air wells are also listed in table 2.

\section{Extent of Saltwater Intrusion, 1939-47}

Only a few wells provided chloride samples in the early 1940's (fig. 12), but the data are generally adequate to determine the approximate position of the saltwater front. The time history of chloride concentrations in the observation wells of this period (fig. 14), together with selected water samples at other wells (table 2), provides the basis for the estimated position. Well locations are shown in figure 12 .

The southern end of the saltwater front is approximated based on a chloride value $(830 \mathrm{mg} / \mathrm{L})$ obtained from well G-1357 in 1968 (table 2). At that time, G-1357 was about $1 \mathrm{mi}$ east of the saltwater front (fig. 15). At well F-279 (117 ft deep) adjacent to the
Biscayne Canal in Dade County (fig. 12), chloride concentrations in the early 1940's (fig. 13) were near the background level considered typical of the Biscayne aquifer. A slight temporary rise in concentration in 1945 probably represents the influence of an extended drought that caused saltwater to migrate up into the canals, most of which were uncontrolled at the time, or around the controls where controls existed. The front was east of F-279 at that time. Just south of Snake Creek Canal near U.S. Highway 1, chloride concentrations in water from S-304 (76 ft deep) were less than $250 \mathrm{mg} / \mathrm{L}$ until mid-1941, but then began to follow a slow, increasing trend until concentrations were consistently greater than $250 \mathrm{mg} / \mathrm{L}$ after 1943 (fig. 14). A water sample from nearby surficial-aquifer drainage well D-151 (175 ft deep) had a a chloride concentration of $7,300 \mathrm{mg} / \mathrm{L}$, indicating that highly saline water occurred at depth at this location. Chloride concentrations in samples from well S-58 $(36 \mathrm{ft}$ deep) indicated both an increasing long-term trend and strong seasonal variations (fig. 14). The latter might have been related to seasonal variations in the upstream migration of seawater in Snake Creek Canal. At well F-300 (9l ft deep) north of Snake Creek Canal, chloride concentrations were at background levels (fig. 14). Farther east at well S-278 (80 ft deep), chloride concentrations were higher than at F-300, though still less than $250 \mathrm{mg} / \mathrm{L}$, indicating that S-278 was relatively near the saltwater front.

Farther north, water samples from wells F-291, F-292, F-293, and F-294 (72 to $200 \mathrm{ft}$ deep) contained only background concentrations of chloride, but three water samples from drainage well D-152 farther east contained chloride in concentrations of $15,000 \mathrm{mg} / \mathrm{L}$ (table 2). Although the depth of D-152 was not known, it is assumed that the longitudinal position of the saltwater front was located in the interval between F-294 and D-152 (fig. 12). Water samples were obtained at selected depths as well G-555 was driven to a depth of 


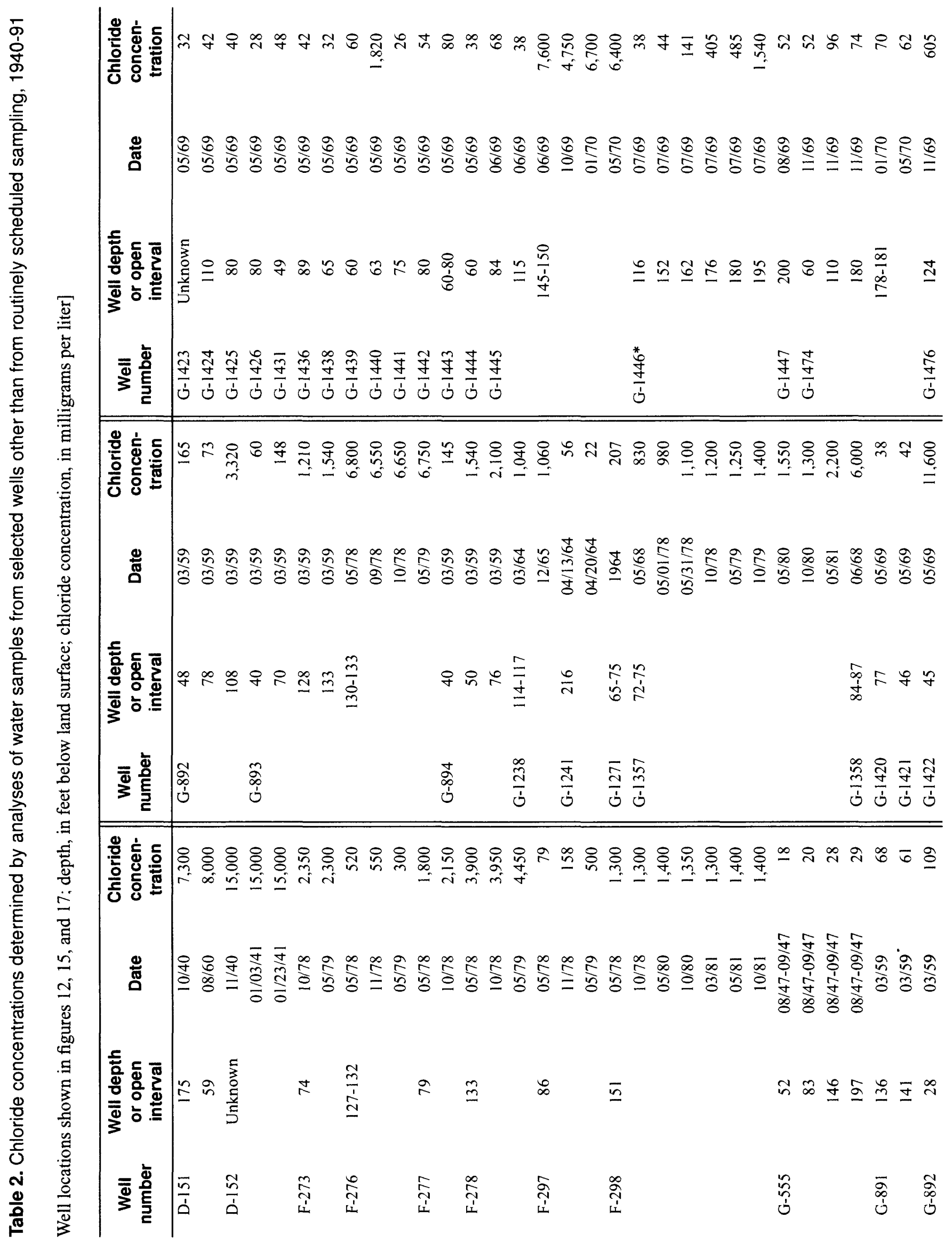




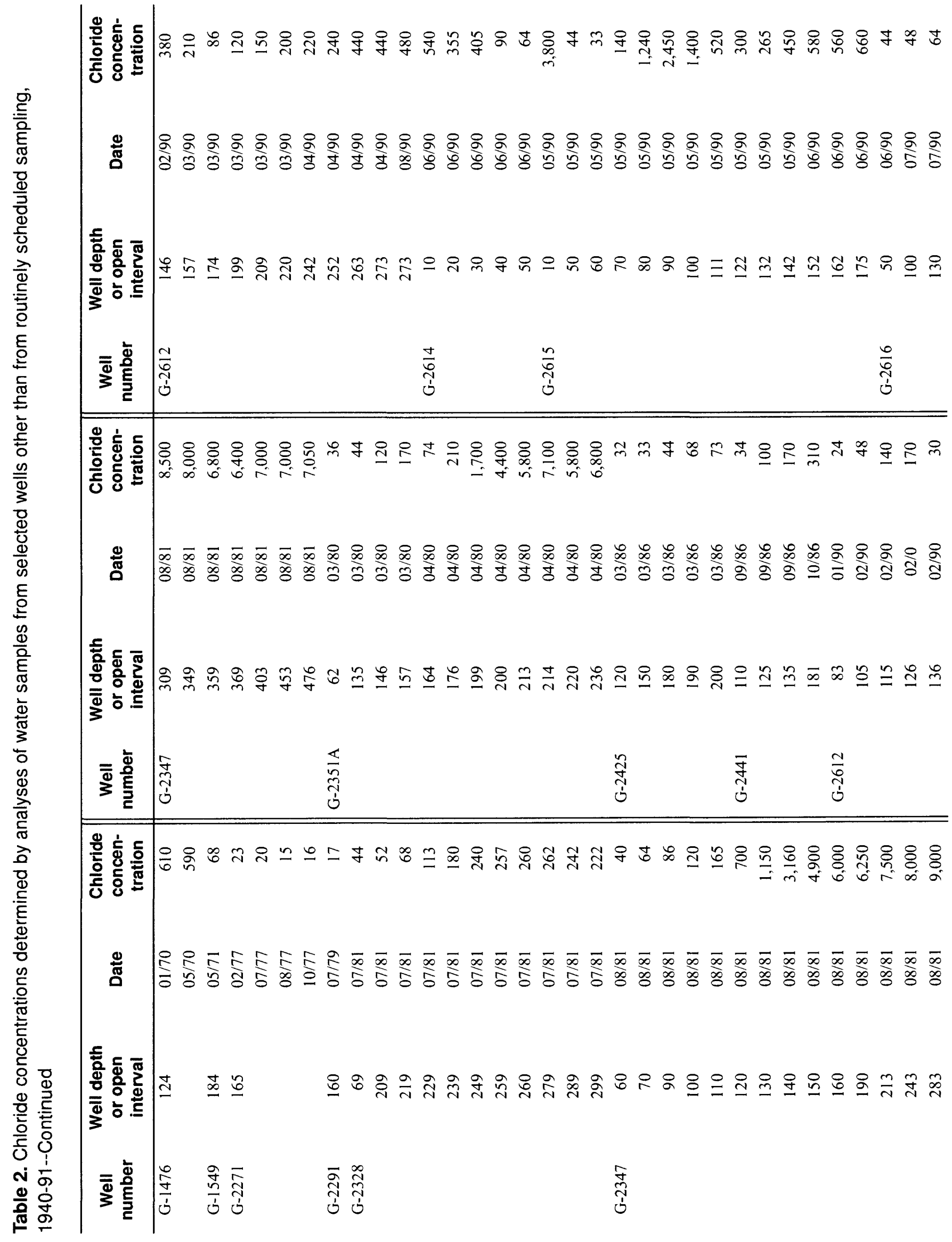




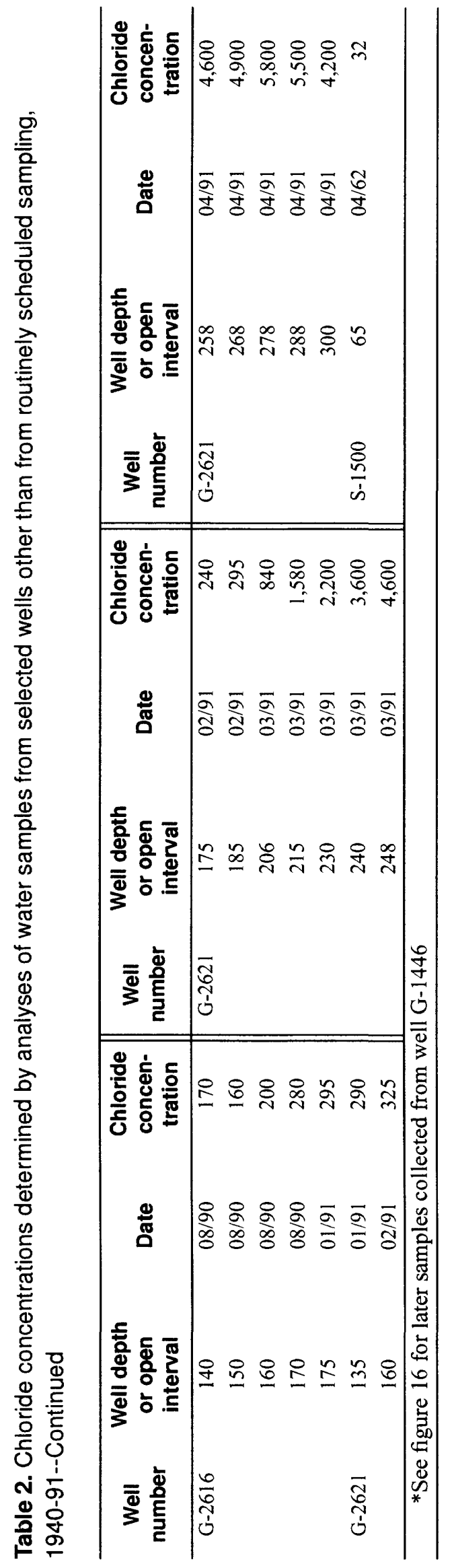




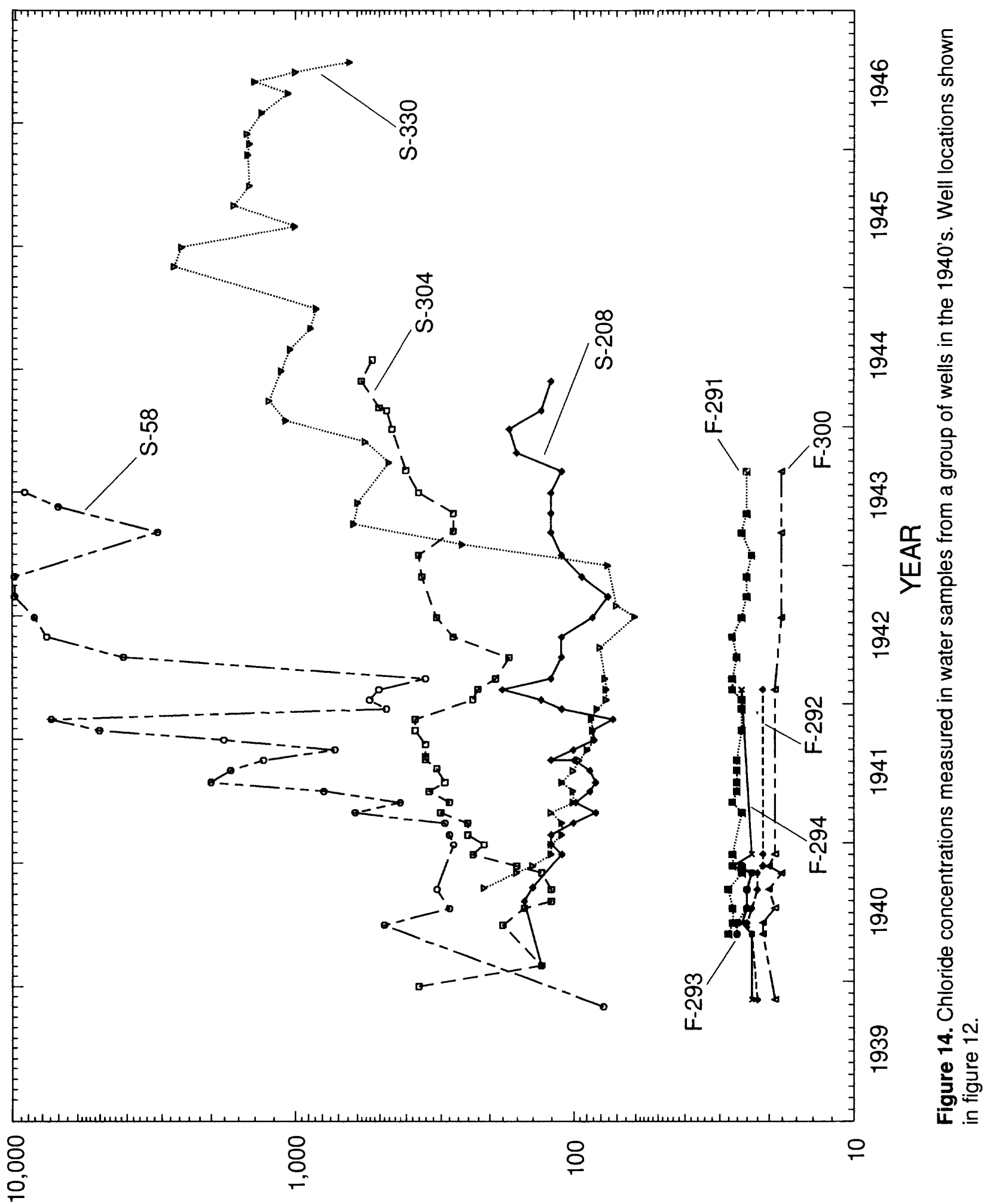

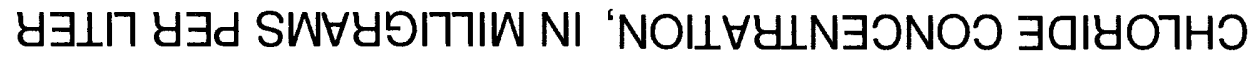



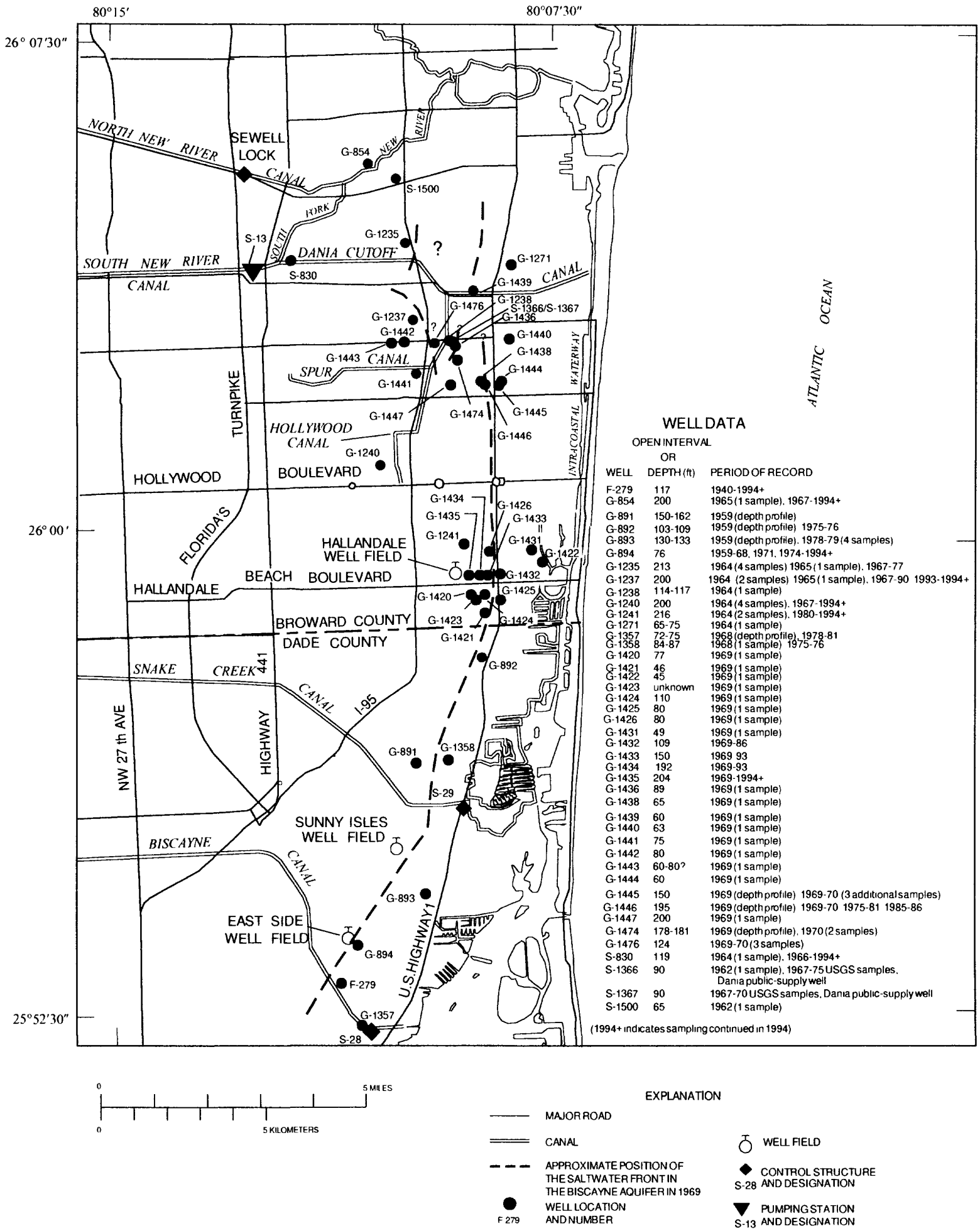

Figure 15. Locations of wells used for detecting and monitoring saltwater intrusion in the 1960's and approximate position of the saltwater front in the pumping zone in 1969. 
$206 \mathrm{ft}$ in 1947. All water samples contained chloride in concentrations less than $30 \mathrm{mg} / \mathrm{L}$. A. well S-330 (35 $\mathrm{ft}$ deep), a supply well for the Dania Florida Power and Light Company power plant, chloride concentrations were somewhat higher than background levels in the early 1940's and began to increase after mid-1943 (fig. 14). Vorhis (1948, p. 27) attributes the increase to upstream movement of saltwater in the Dania Cutoff Canal during a drought period of unusual severity. Possibly, pumping for the power plant supply caused a local southward migration of saltwater from the Dania Cutoff Canal. If so, the relation between the coastal saltwater front and saltwater intruding from the canal was not clear, and no estimate of the position of the saltwater front in 1945 was possible north of well G-555.

\section{Extent of Saltwater Intrusion, 1959-76}

In the study area, the regular collection of water samples for chloride analysis from well F-279 was augmented in 1959 by the initiation of regular sampling at well G-894, east of the East Side Well Field owned by the City of North Miami. Depth profiles of chloride (table 2) were acquired in 1959 from the drilling of G-894, G-891, G-892, and G-893, all in northeastern Dade County (fig. 15). Various single water samples were obtained from wells drilled in the early and middle 1960's (fig. 15), and regular sampling at well S-830 at the junction of the South New River Canal, the Dania Cutoff Canal, and the South Fork New River began in 1966. A sampling network for southeastern Broward County began to take shape in 1967 with the addition of previously drilled wells G-854, G-1235, G-1237, and G-1240. In addition, chloride concentrations at supply wells S-1366 and S-1367 at the City of Dania Well Field were too high for the water to be used for public supply (exceeding $300 \mathrm{mg} / \mathrm{L}$ at well S-1367 in 1967 and at well S-1366 in 1971), and the wells were added to the sampling network.

A single chloride concentration (table 2) at about $75 \mathrm{ft}$ was obtained from G-1357 on the Biscayne Canal just above salinity-control structure S- 28 in 1968 , and three depth profiles of chloride concentration (at wells G-1445, G-1446, and G-1474) were acquired in the Dania area in 1969. In that year, a large number of existing wells in the Dania and Hallandale areas were identified and sampled for chloride analysis by H.W. Bearden of the USGS. Wells G-1432, G-1433, G-1434, and G-1435 were drilled on a line east of the Hallandale Well Field and added to the regular sampling network (Bearden, 1972), as was G-1446 east of the City of Dania southern (cemetery) well field (fig. 15).
In the southern part of the area shown in figure 15. water samples from well F-279 exceeded 1,300 $\mathrm{mg} / \mathrm{L}$ in chloride concentration in 1969 (fig. 13). Water pumped from wells in 1969 in the Sunny Isles Well Field owned by the City of North Miami Beach contained chloride in concentrations that exceeded $250 \mathrm{mg} / \mathrm{L}$ (Richard Coates, City of North Miami Beach Utilities, oral commun., 1994). Development of a new well field began, and when it was completed in 1972, pumping from the Sunny Isles Well Field was discontinued. Well G-894 produced water with chloride concentrations exceeding $2,000 \mathrm{mg} / \mathrm{L}$ at $76 \mathrm{ft}$ when drilled in 1959. Chloride concentrations in water samples from many of the supply wells in the East Side Well Field owned by the City of North Miami were above $400 \mathrm{mg} / \mathrm{L}$ during the 1971 drought. Chloride concentrations at the supply wells increased again during the dry seasons of 1974,1975 , and 1976.

Pumping was later discontinued because of the seasonal pattern of increasing chloride concentrations. It is likely that the shallow depth of many of these wells (30 to $40 \mathrm{ft}$ ) allowed their continued use for some time after saltwater was detected in the area.

North of Snake Creek Canal, water samples from well G-891 were fresh to a depth of $162 \mathrm{ft}$ below land surface and water samples from well G-892 contained chloride in a concentration exceeding $3,000 \mathrm{mg} / \mathrm{L}$ at a depth of $108 \mathrm{ft}$ when both wells were drilled in 1959 (table 2). Water samples from well G-1358 had a chloride concentration of $6,000 \mathrm{mg} / \mathrm{L}$ at a depth of $84 \mathrm{ft}$ when drilled in 1968. The position of the saltwater front was identified with some accuracy in the Hallandale area because of the density of wells providing data (fig. 15). A water sample from well G-1432 at a depth of $109 \mathrm{ft}$ had a chloride concentration exceeding $3,000 \mathrm{mg} / \mathrm{L}$ when the well was drilled in 1969 . A water sample from well G-1433 at a depth of $150 \mathrm{ft}$ had a chloride concentration of $140 \mathrm{mg} / \mathrm{L}$ in 1969 , indicating that the Biscayne aquifer was still fresh at that location and depth. However, the chloride concentration of a water sample from well G-1434, drilled to a depth of $192 \mathrm{ft}$ and located $800 \mathrm{ft}$ west of G-1433 and closer to the Hallandale Well Field (fig. 15), was $1,400 \mathrm{mg} / \mathrm{L}$ in 1969 , indicating that the saltwater front was relatively close to the well field.

In the Dania area, a group of wells used to obtain water samples for chloride analyses helps to define the position of the saltwater front in 1969. Depth profiles were obtained from wells G-1445, G-1446, and G-1474 (table 2) when drilled in 1969. Water with a chloride concentration of $7,600 \mathrm{mg} / \mathrm{L}$ occurred in $\mathrm{G}-1445$ at $145 \mathrm{ft}$, but a water sample from G-1446 at $180 \mathrm{ft}$ had a chloride concentration of $485 \mathrm{mg} / \mathrm{L}$. 
Freshwater was present to the total depth of well G$1474(181 \mathrm{ft})$. The chloride concentrations of water samples from well S-1366 at the City of Dania water plant about $1 \mathrm{mi}$ to the northwest (fig. 15) were less than $200 \mathrm{mg} / \mathrm{L}$ in 1969 , but began to exceed $500 \mathrm{mg} / \mathrm{L}$ in 1972. The chloride concentration of samples from $\mathrm{S}-1367$ exceeded $300 \mathrm{mg} / \mathrm{L}$ in 1969. Chloride concentrations in water samples obtained from G-1238 (114 $\mathrm{ft}$ deep) in the mid-1960's exceeded 1,000 $\mathrm{mg} / \mathrm{L}$. Because of the proximity of S-1366, S-1367, and G-1238 to the tidal Hollywood Canal, it is likely that the salinity of water samples from these wells is caused by saltwater intrusion from the canal. A relatively shallow $(63 \mathrm{ft})$ water sample obtained in 1969 from well G-1440, located at some distance east of the Hollywood Canal and south of the Dania Cutoff Canal, had a chloride concentration of more than $1,800 \mathrm{~m} / \mathrm{gL}$, suggesting that the coastal saltwater front was west of G-1440 at this time. A water sample obtained at $60 \mathrm{ft}$ from G-1439, just north of the Dania Cutoff Canal, in 1969 was fresh. Because of the complex pattern of saltwater intrusion from the ocean and from the canal and the paucity of data, it was not possible to estimate a saltwater front position in the vicinity of the Dania Cutoff Canal north of G-1440 (fig. 15).

Water samples from well G-1476 (124 ft deep) had chloride concentrations of about $600 \mathrm{mg} / \mathrm{L}$ in 1969 and 1970. Water samples collected from well G-1237 (200 ft deep) between 1967 and 1969 had chloride concentrations less than $250 \mathrm{mg} / \mathrm{L}$, and concentrations actually decreased for the next several years. These data suggest a saltwater front in the area, but the intrusion of saltwater may be from the Dania Cutoff, Hollywood, and Spur Canals rather than from the ocean.

The high chloride concentrations of water samples from well S-830 (fig. 16) suggest saltwater intrusion from along the tidal Dania Cutoff Canal. North of the canal, water samples from well G-1235 $(213 \mathrm{ft}$ deep) were fresh in 1964 and 1965, but when sampling began on a regular basis in 1967, chloride concentrations averaged $800 \mathrm{mg} / \mathrm{L}$. These data indicate an influx of saltwater at depths below the Biscayne aquifer, possibly originating from the Dania Cutoff Canal or the South Fork New River (fig. 15). Water at at well G-1271 had a chloride concentration of about $200 \mathrm{mg} /$ $\mathrm{L}$ at $75 \mathrm{ft}$ in 1964, suggesting that lower intervals of the Biscayne aquifer were probably intruded by saltwater. Water from well S-1500 was fresh in 1962, but the well was only $65 \mathrm{ft}$ deep. The high chloride concentrations in water from well G-854 (fig. 16) might indicate seepage of saltwater from the tidal South Fork New River, but the lack of data in the vicinity of the tidal river means that an appraisal of its effect in causing the seepage of saltwater into the aquifer cannot be made. Based on the very limited data available, it seems likely that the presence of saltwater in the aquifer between the Dania Cutoff Canal and the South Fork New River occurs from a combination of sources that include the ocean, canal, and river.

\section{Extent of Saltwater Intrusion, 1976-94}

The regularly scheduled collection of water samples for chloride analysis was greatly expanded in the study area in the 1970's by the use of existing wells and the drilling of new ones. Several additional wells were drilled for regularly scheduled sampling in the 1980's. Most of the additional network wells were near the Hallandale Well Field, Hollywood Well Field, or Broward County Utilities Well Field 3A. Exceptions were wells G-2425, G-2426, and G-2441 in the City of Hollywood, and wells G-2129 and G-2130 north of the confluence of South Fork New River and North New River Canal. Several depth profiles of chloride concentration were obtained as part of the present study and a previous USGS study (Howie, 1987). The chloride data from all of these sources were generally adequate to define the position of the saltwater front in 1993 (fig. 17).

In the southern part of the study area, existing fire-control wells east and south of the North Miami East Side Well Field (F-273, F-276, F-277, F-278, F-297, and F-298) were identified and sampled in 1978-79 (fig. 17) to augment chloride concentration data from regularly collected water samples from wells F-279 and G-894. Pumping from the well field had been discontinued, probably in 1977. The Sunny Isles Well Field, owned by the City of North Miami Beach, was shut down in 1972. In 1978 and 1979, chloride concentrations in most of the fire-control well water samples exceeded $1,300 \mathrm{mg} / \mathrm{L}$ (table 2). Chloride concentrations in water samples from wells F-297 and F-276, however, fluctuated above and below the 250-mg/L chloride limit for potability (table 2 ). The chloride concentration of samples from well G-894, hydraulically upgradient to the northwest of wells F-279 and F-276, continued to exceed 1,000 mg/L. Beginning in 1981, however, chloride concentrations from well G-894 water samples started a downward trend (fig. 16). Since 1983, chloride concentrations of samples from well G-894 have been similar to those of freshwater in other parts of the Biscayne aquifer used for public supply. The chloride concentration of water samples from well F-279 continued to exceed 1,000 $\mathrm{mg} / \mathrm{L}$. Based on the chloride concentrations from well G-894, the 1993 saltwater front line between Biscayne and Snake Creek Canals has been drawn slightly seaward of the 1969 line. 


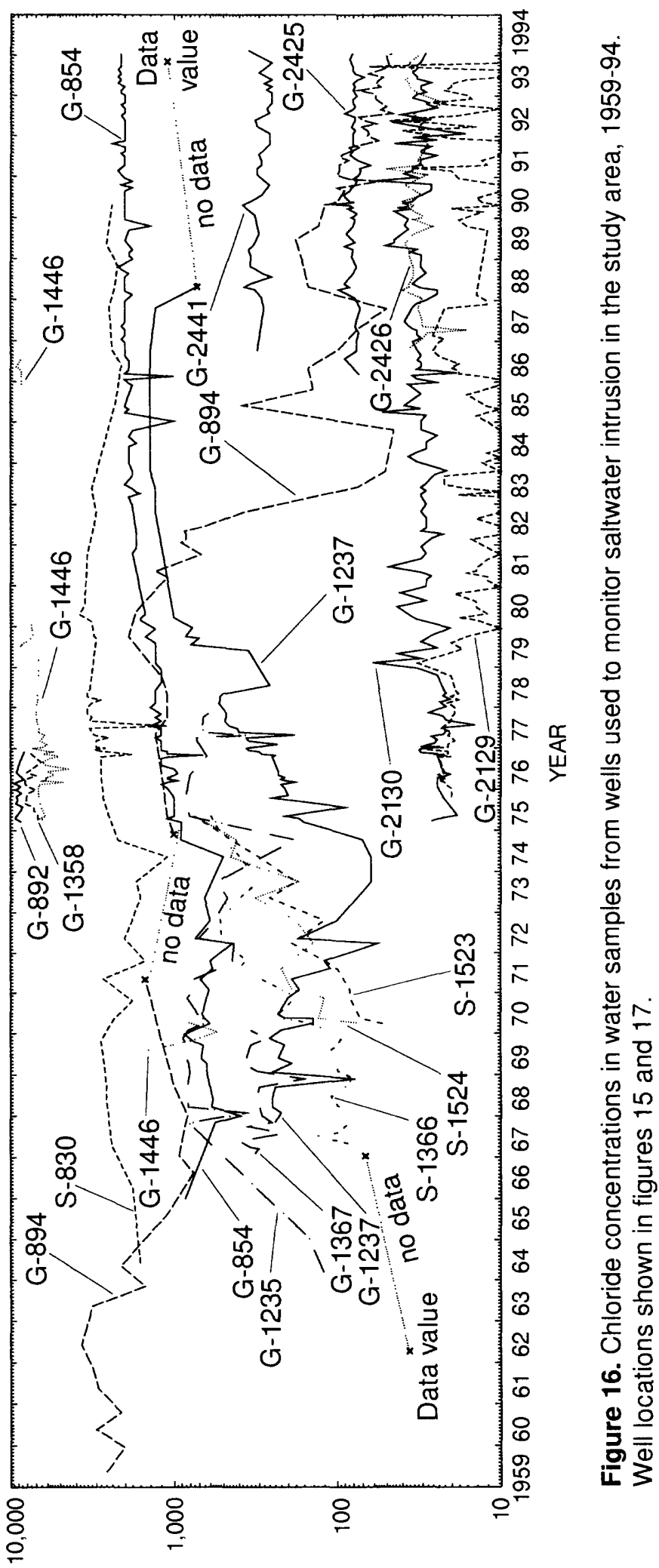

ㅂ\} 


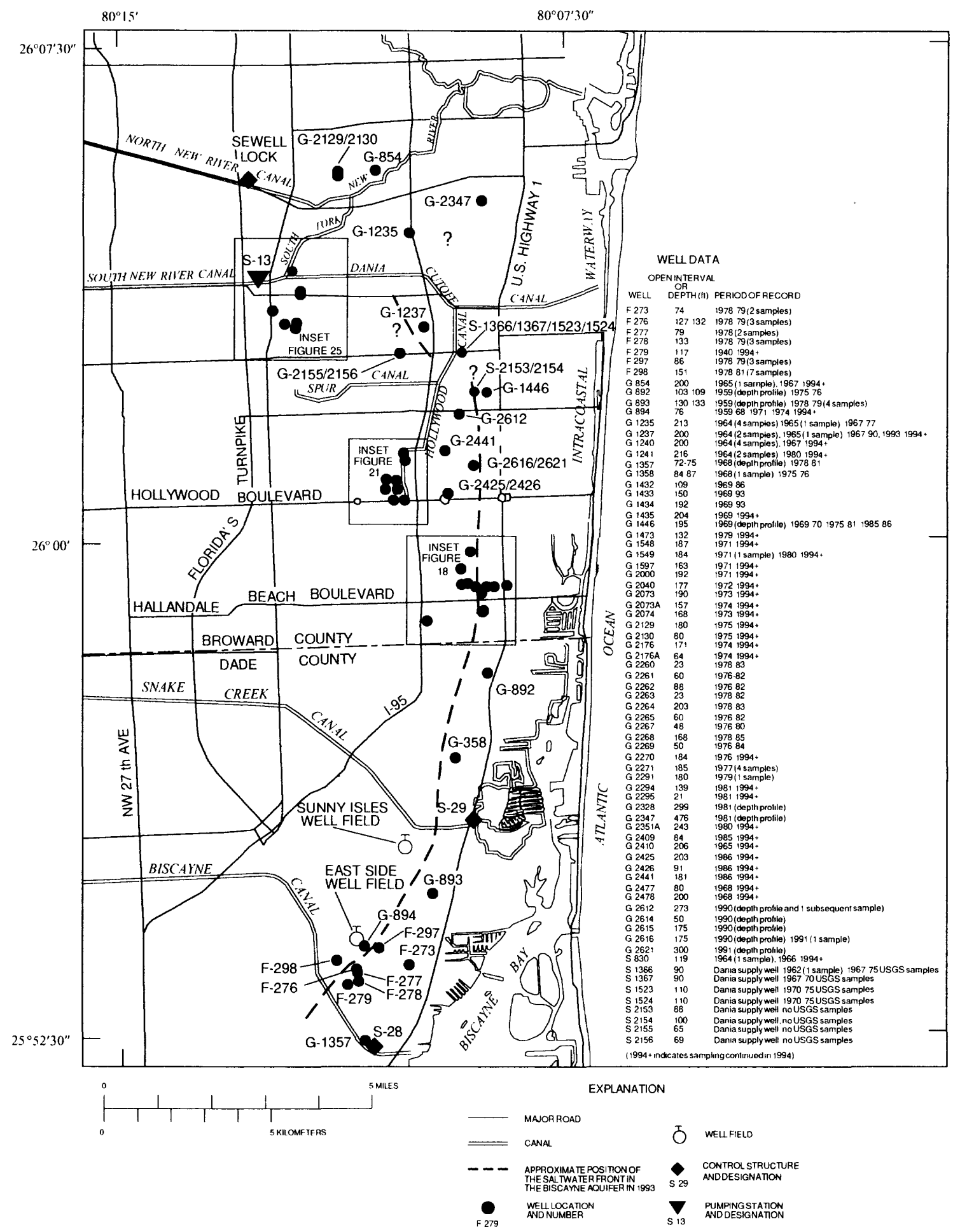

Figure 17. Locations of wells used for detecting and monitoring saltwater intrusion in the 1970's, 1980's, and 1990's and approximate position of the saltwater front in the pumping zone in 1993. 
Immediately north of Snake Creek Canal in northern Dade County, the saltwater front position in 1993 is highly approximate because of the lack of useful chloride samples. Wells G-1358 and G-892 (fig. 16) are relatively shallow and were periodically sampled for a short time in 1975-76. The chloride concentrations of water samples exceeded $6,000 \mathrm{mg} / \mathrm{L}$ at both sites. Farther north, a network of chloride sampling wells in the vicinity of the Hallandale Well Field (fig. 18 ) provide a substantial data base for locating the saltwater front. Many additional monitoring wells were drilled in this area in the 1980's as previous monitoring wells began to yield water samples containing increasingly higher concentrations of chloride (fig. 19), and the city needed to verify that the saltwater front had not yet reached the well field. Finally, the main well field at the Hallandale water plant discontinued pumping in 1988. In that year, additional monitoring wells (G-2477 and G-2478) were drilled to replace well G-124l where chloride concentrations in water samples, less than $100 \mathrm{mg} / \mathrm{L}$ in 1983 , progressively increased to more than $4,000 \mathrm{~m} / \mathrm{gL}$ in 1993 (fig. 19). The new wells could provide an early warning of the advance of the saltwater front toward well 7 , which is used as a standby for the remaining supply well (well $8)$.

In 1993, deep monitoring wells G-1435 and G-2351A, seaward of the Hallandale Well Field, were yielding water samples with chloride concentrations in excess of $6,000 \mathrm{mg} / \mathrm{L}$ (fig. 19). Pumping zone monitoring well G-2294 and deep monitoring well G-2410 were beginning to show chloride concentration increases. Samples from well G-2074, just below the pumping zone, had chloride concentrations in excess of $8,000 \mathrm{mg} / \mathrm{L}$. The saltwater front line was, therefore, drawn approximately through the locations of wells G-2294 and G-1241, which at a depth of $216 \mathrm{ft}$ is far below the pumping zone.

The movement of the saltwater front east of the Hallandale Well Field from 1970, when data collection began, to 1993 (fig. 20) was estimated on the basis of the chloride concentration data presented in figure 19. The 50-percent seawater concentration lines in 1970, 1985 , and 1993 were drawn using chloride concentration data from wells G-1432, G-1433, G-1434, G-1435, and G-2351 A. Because data from well G-2328 at a depth of $300 \mathrm{ft}$ were acquired in 1981, the 50 -percent saltwater concentration line position for 1985 is estimated to that depth. It is noted that the points in figure 20 generally represent the bottom of the wells. Wells G-1432, G-1433, G-1434, and G-1435 have open-hole intervals of 4 to $8 \mathrm{ft}$ above the bottom of the well. Well G-2351 A is open from $200 \mathrm{ft}$ to the bottom of the well at $243 \mathrm{ft}$, the result of construction difficulties while drilling (H.J. Voegtle, U.S. Geological Survey, oral commun., 1981). Water samples are considered to most likely represent the quality of aquifer water at $200 \mathrm{ft}$, which leads to an interpretation consistent with the data from the other wells.

However, it is noted that data are not available to identify the depth interval contributing the greatest amount of water during sampling.

The saltwater front estimates for 1970,1985 , and 1993 are somewhat subjective because the lack of nearly adjacent wells at the various depths made it difficult to fully define the transition zone. On the basis of the available data, the transition zone appeared to be rather sharp. Water samples from well G-2294 in 1985 contained chloride in concentrations of only about $100 \mathrm{mg} / \mathrm{L}$, and water samples from well G-2410 in 1993 contained chloride in concentrations of only about $90 \mathrm{mg} / \mathrm{L}$. The apparent lack of movement of the upper part of the interface between 1985 and 1993 could be a result of the termination of pumping from the main Hallandale Well Field in 1988.

Considerable concern exists about the continued availability of the Hollywood Well Field, the third largest in Broward County. The production wells of the Hollywood Well Field have always produced freshwater. A network of monitoring wells was drilled in the 1970's (fig. 21). Water samples from some of the wells (G-1548, G-1597, and G-2000) had chloride concentrations greater than those of water samples previously collected from well G-1240 (fig. 22). However, the chloride concentrations of water samples from the monitoring wells have not shown increasing trends for over 20 years. Water samples from some wells (G-1240, G-2040, and G-2176) have shown downward fluctuations since 1981. Together with the fact that some wells drilled on the east side of the Hollywood Canal have yielded freshwater samples at depths equivalent to those of the Hollywood monitoring network, the chloride concentration data from the monitoring network suggest that the source of saltwater causing the well water samples to be of relatively high salinity is not the saltwater wedge from the Atlantic coast but rather partially diluted seawater seeping from the tidal Hollywood Canal.

Water in the Hollywood Canal tends to show seasonal fluctuations in salinity that depend upon the amount of rainfall, and the salinity of water samples collected regularly by the USGS tends to decrease with distance from the Dania Cutoff Canal. Along the Hollywood Canal, the chloride concentrations of Taft Street water samples tend to be higher than those of contemporaneous Johnson Street water samples, 


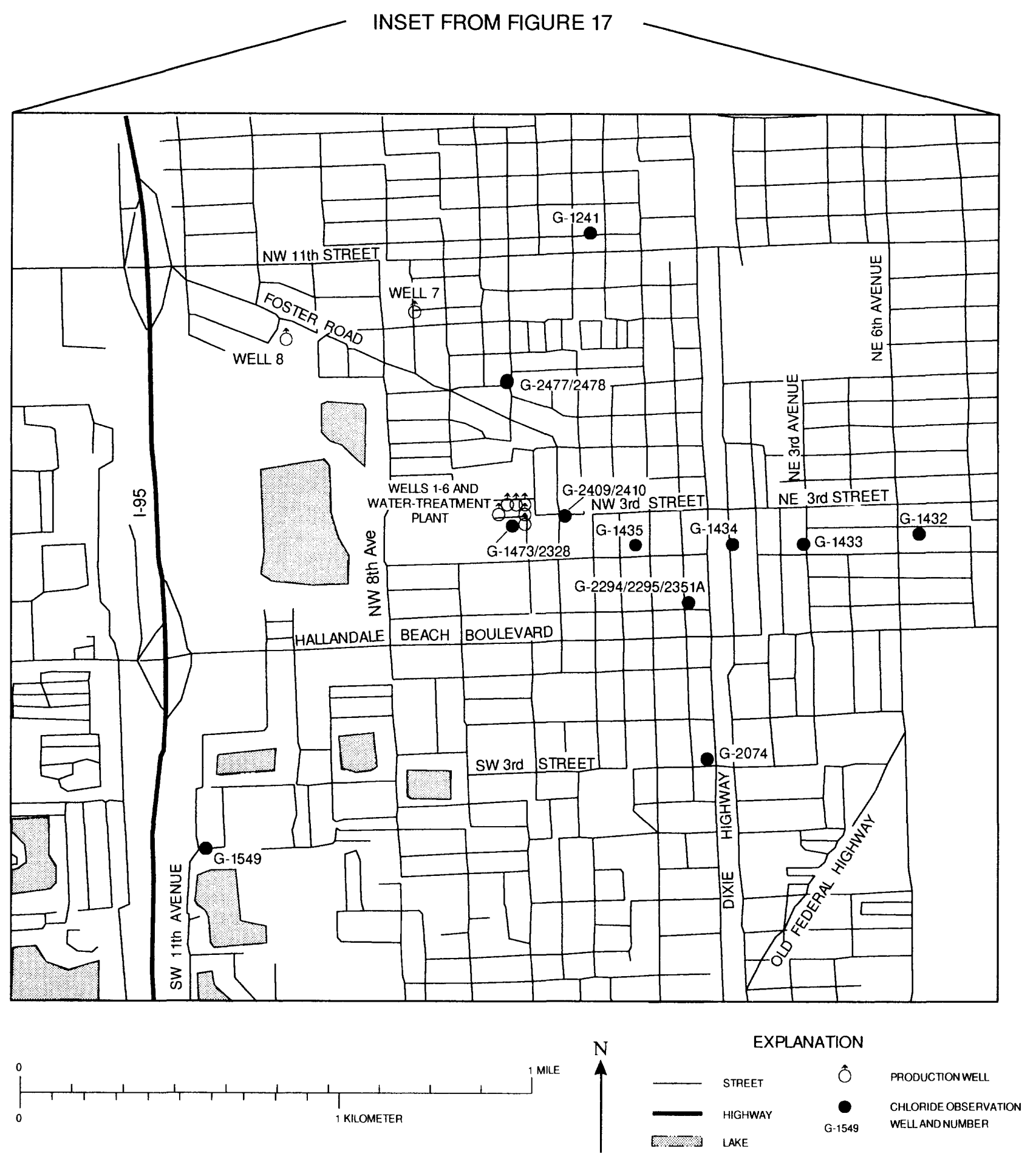

Figure 18. Locations of wells used for detecting and monitoring saltwater intrusion in the vicinity of the Hallandale Well Field. 


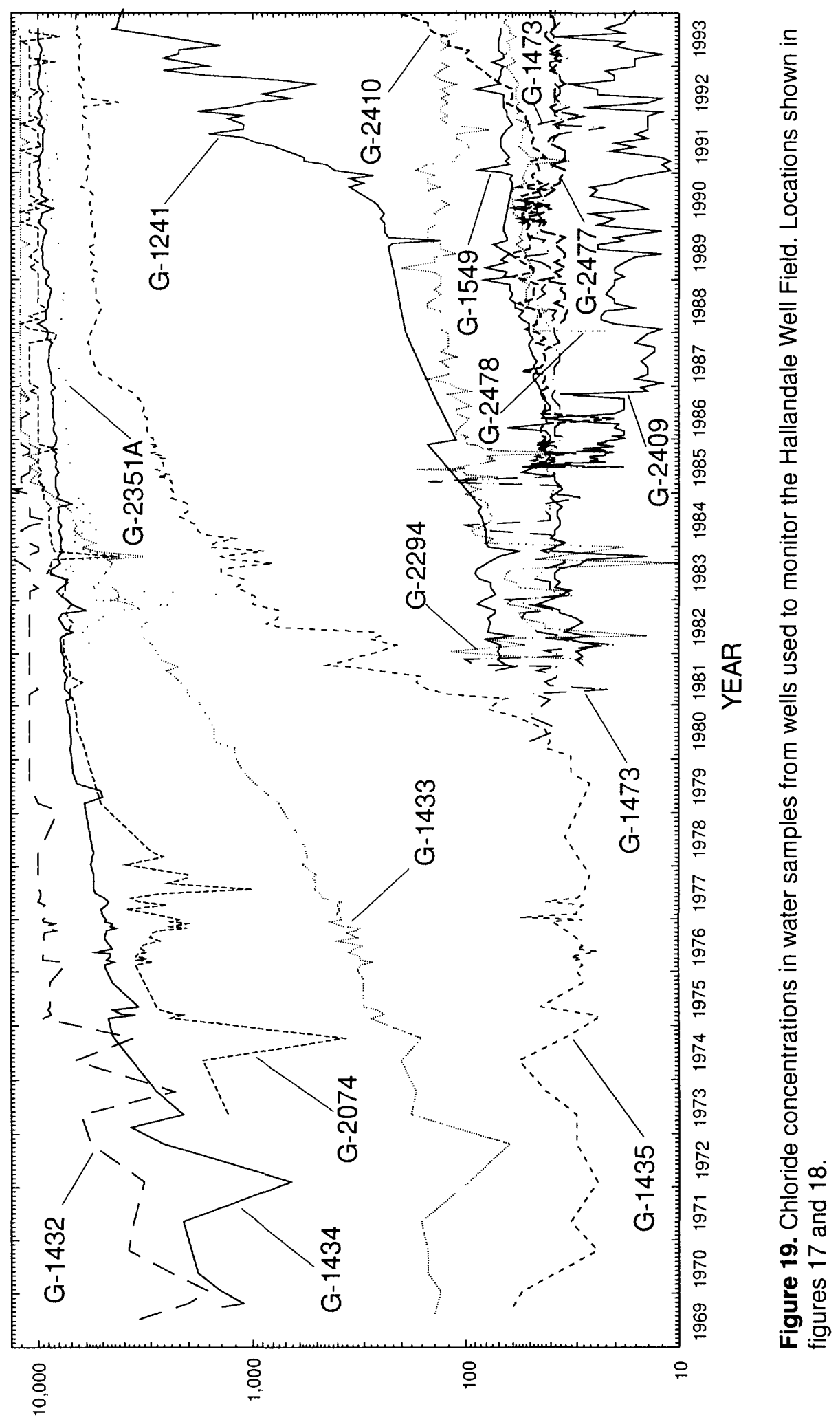

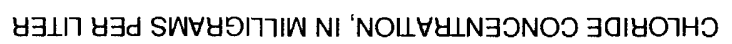




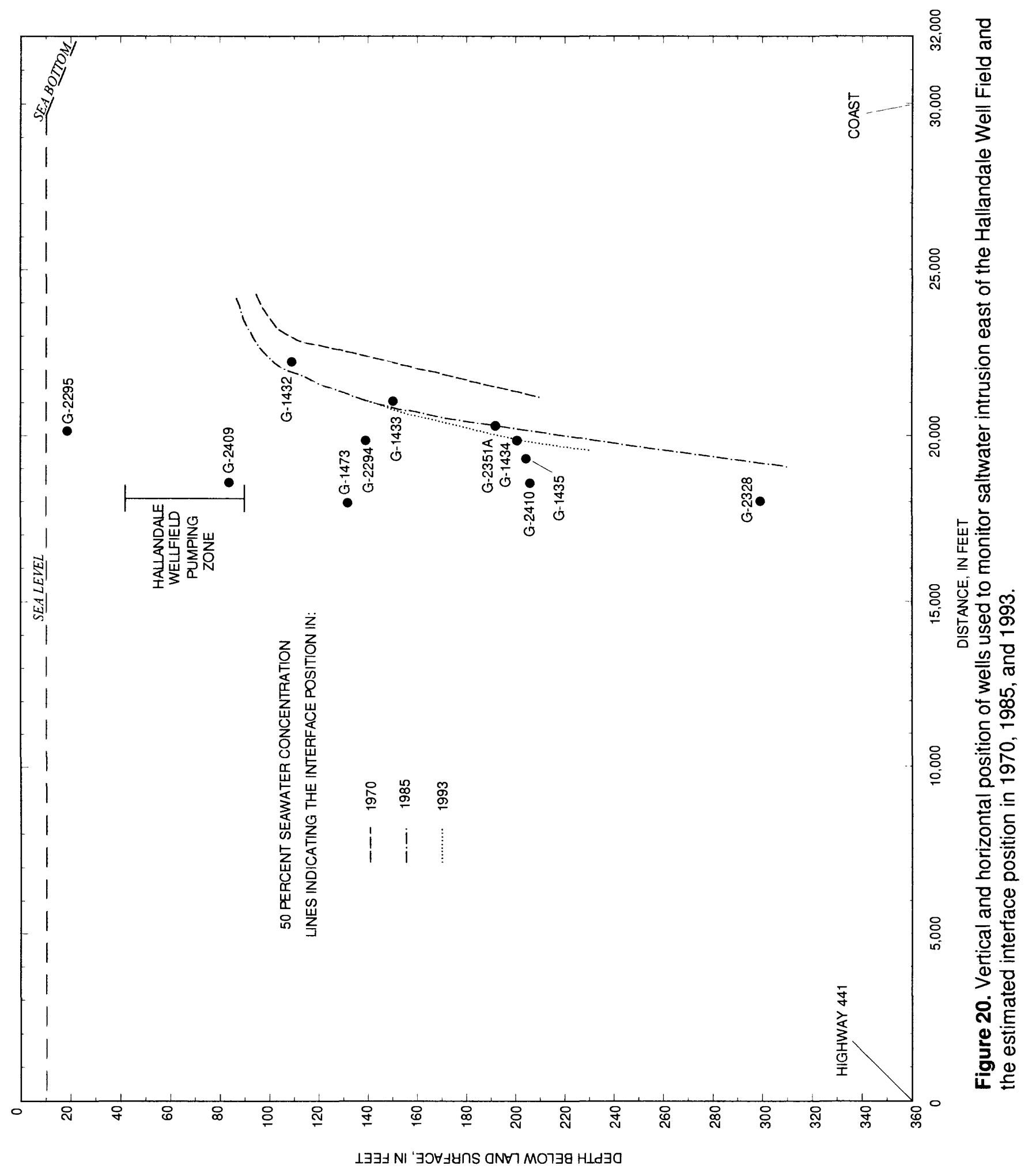



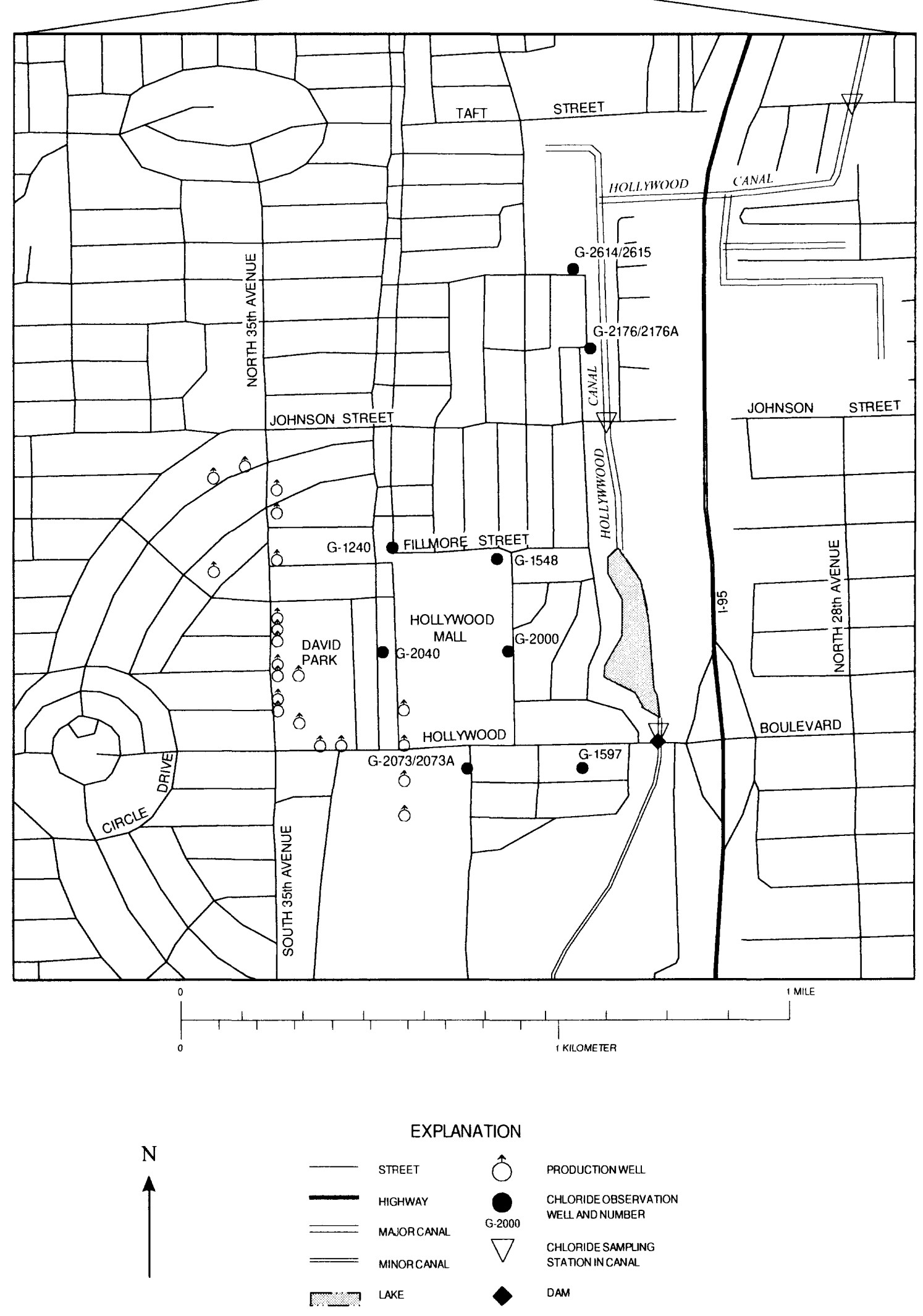

Figure 21. Locations of wells used for detecting and monitoring saltwater intrusion east of the Hollywood Well Field. 


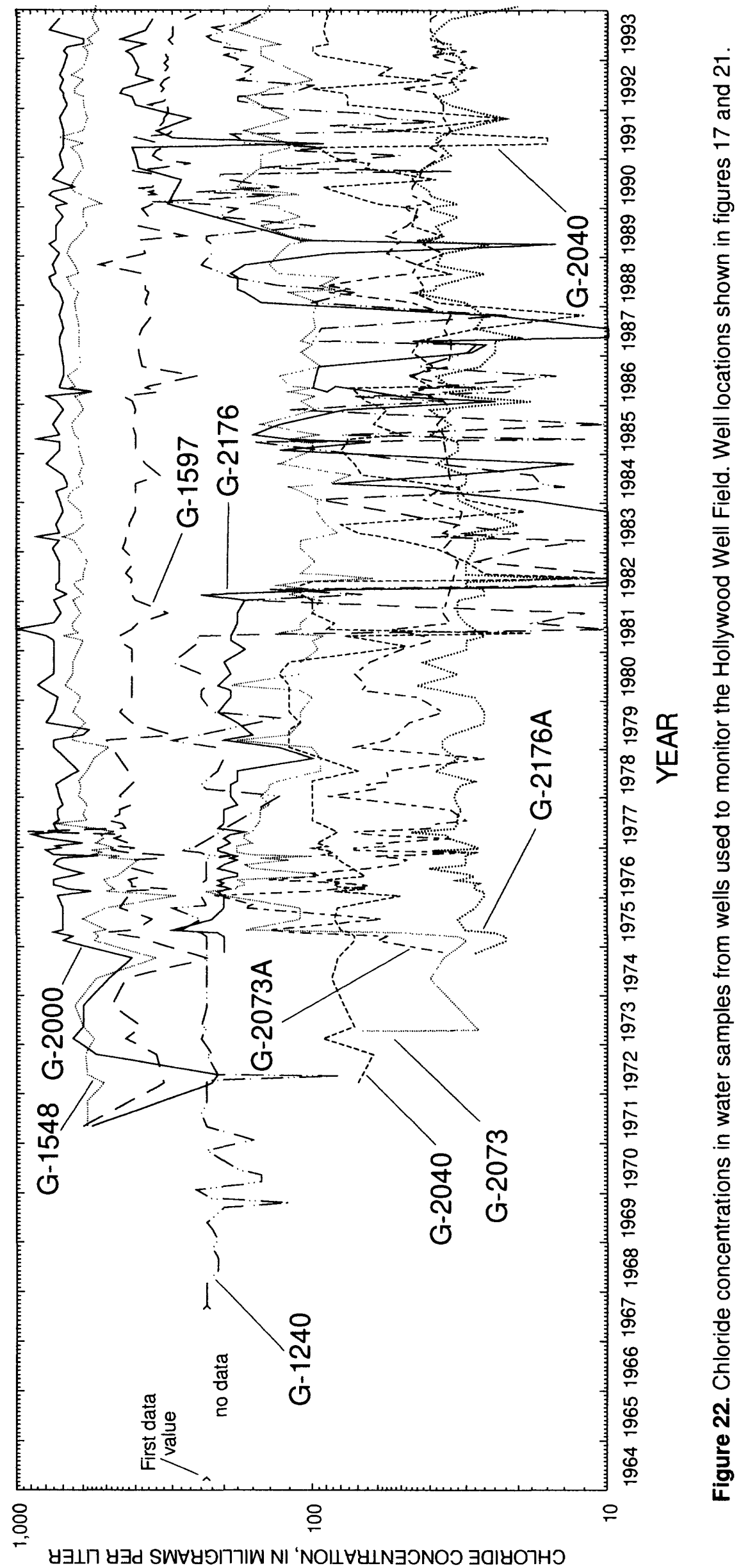


which in turn, tend to be higher than the chloride concentrations of water samples collected at the dam at the end of the tidal reach at Hollywood Boulevard (fig. 23). Along the Spur Canal, water samples taken at N. 29th Avenue, $0.75 \mathrm{mi}$ west of the Hollywood Canal, generally have higher chloride concentrations (fig. 24) than water samples collected at the dam at the western end of the tidal reach at N. 46th Ave. The seasonal fluctuation of chloride concentration in both canals is seen to be over a range that is very large ( 20 to 15,000 $\mathrm{mg} / \mathrm{L}$ ) and that has remained consistent for more than 25 years.

As part of the present study, well G-2615 was drilled $100 \mathrm{ft}$ from the west bank of the Hollywood Canal near the end of the dry season in May and early June 1990. The purpose was to gain information about the vertical subsurface distribution of chloride near the canal. The well was driven to $175 \mathrm{ft}$ below land surface as water samples for chloride analysis were obtained every $10 \mathrm{ft}$. Results (table 2 ) show an interval of relatively high chloride concentration $(1,240-2,450$ $\mathrm{mg} / \mathrm{L}$ ) between 80 and $100 \mathrm{ft}$ below land surface, which is within the 50 to $150 \mathrm{ft}$ interval that usually contains the pumping zones used by well fields. A high chloride concentration $(3,800 \mathrm{mg} / \mathrm{L})$ was measured at $10 \mathrm{ft}$, but no water samples were collected between 10 and $50 \mathrm{ft}$. At the latter depth, the chloride concentration was less than $50 \mathrm{mg} / \mathrm{L}$. Later in June, after heavy rains of the wet season had begun, a second well (G-26 14) was driven to $50 \mathrm{ft}$. Water samples were acquired every $10 \mathrm{ft}$. Chloride concentrations ranged from 350 to $550 \mathrm{mg} / \mathrm{L}$ to $30 \mathrm{ft}$ below land surface. Below this depth, concentrations decreased to a level only slightly more saline (less than $100 \mathrm{mg} / \mathrm{L}$ ) than the background concentration in the Biscayne aquifer where saltwater intrusion has not occurred. The stratification of salinity at this location is regarded as evidence that the source of the saltwater intrusion is the canal, the bottom of which is within $20 \mathrm{ft}$ of land surface. The lower chloride concentrations after summer rains began were consistent with the flushing of the canal with freshwater runoff and the dilution of saline ground water near the surface by fresh rainfall recharge.

In 1986, wells G-2425 and G-2441 were drilled east of the Hollywood Canal (fig. 17) to determine if oceanic saltwater had intruded into this area. Drilling of well G-2425 was by the dual-tube reverse air method, which was shown to provide accurate depth profiles of chloride concentration (Fish, 1988). Percussion-driven well G-2441 also provided a depth profile of chloride concentration. Well G-2425 was completed at $200 \mathrm{ft}$ below land surface where the chloride concentration was less than $75 \mathrm{mg} / \mathrm{L}$ (table 2).
Well G-2441 was completed at $181 \mathrm{ft}$ below land surface where the chloride concentration was about 300 $\mathrm{mg} / \mathrm{L}$, only slightly higher than the secondary potability standard of $250 \mathrm{mg} / \mathrm{L}$. Chloride concentrations increased with depth in both wells. The higher concentrations in well G-2441 may indicate the influence of the nearby Hollywood Canal because the chloride concentrations have remained stable, displaying the same lack of any trend as noted for the monitoring wells for the Hollywood Well Field.

Wells G-2612, G-2616, and G-262l (fig. 17) were drilled as part of the present study to further determine the extent of oceanic saltwater intrusion east of the Hollywood Well Field. The wells were percussion driven to various depths. Water samples were collected every $10 \mathrm{ft}$. Well G-2612 was completed at 273 $\mathrm{ft}$ below land surface, where two water samples collected 4 months apart were only slightly saline (400 to $500 \mathrm{mg} / \mathrm{L}$ chloride concentration). Slight fluctuations in the vertical profile of chloride concentration at 120 and $150 \mathrm{ft}$ (table 2) might have been caused by intrusion into more permeable zones within the Biscayne aquifer from secondary "finger" canals branching off from the Hollywood Canal and extending to within $2,000 \mathrm{ft}$ of well G-2612. Well G-2616 was completed at $175 \mathrm{ft}$ when a drill bit was lost in the hole. The chloride concentration $(295 \mathrm{mg} / \mathrm{L})$ at this depth was only slightly above the potability standard. A second well (G-2621) was begun a few feet away and was completed to a depth of $300 \mathrm{ft}$ below land surface. A transition from freshwater to water with chloride concentration ranging from 4.000 to $5,000 \mathrm{mg} / \mathrm{L}$ occurred between 200 and $250 \mathrm{ft}$. Well G-2621 is considered to be inland of the saltwater front as defined in the present study, but it seems probable that the oceanic saltwater front is only a short distance seaward of the well. However, the possibility that the saltwater is from the Hollywood Canal cannot be entirely excluded.

In the Dania area, the chloride concentrations of water samples from well G-1446 (fig. 17) were significantly higher in the mid-1970's (fig. 16) than in 196970. Dania supply wells S-2153 and S-2154 at the cemetery well field were used on a standby basis until 1985, when chloride concentrations became too high for the wells to be used further. Water samples from Dania supply wells S-1366, S-1367, S-1523, and S-1524 began to contain high concentrations of chloride in the 1970's (fig. 16). It is difficult to delineate the source(s) of saltwater intrusion in the Dania area east of the Hollywood Canal because of the proximity of both the oceanic saltwater front and the tidal Dania Cutoff and Hollywood Canals and because of the lack 


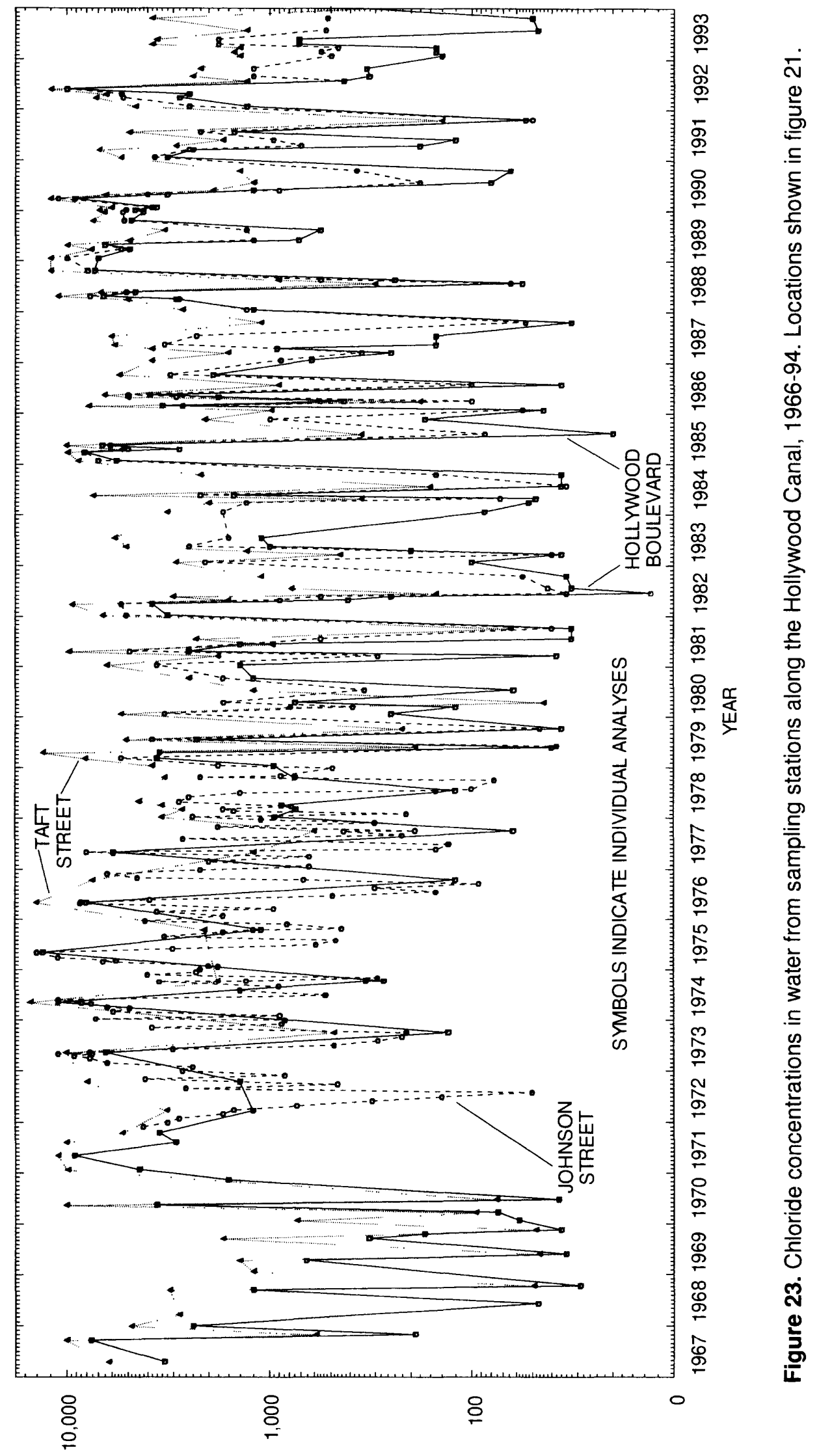

ㅂ॥17 $y \exists d$ SW 


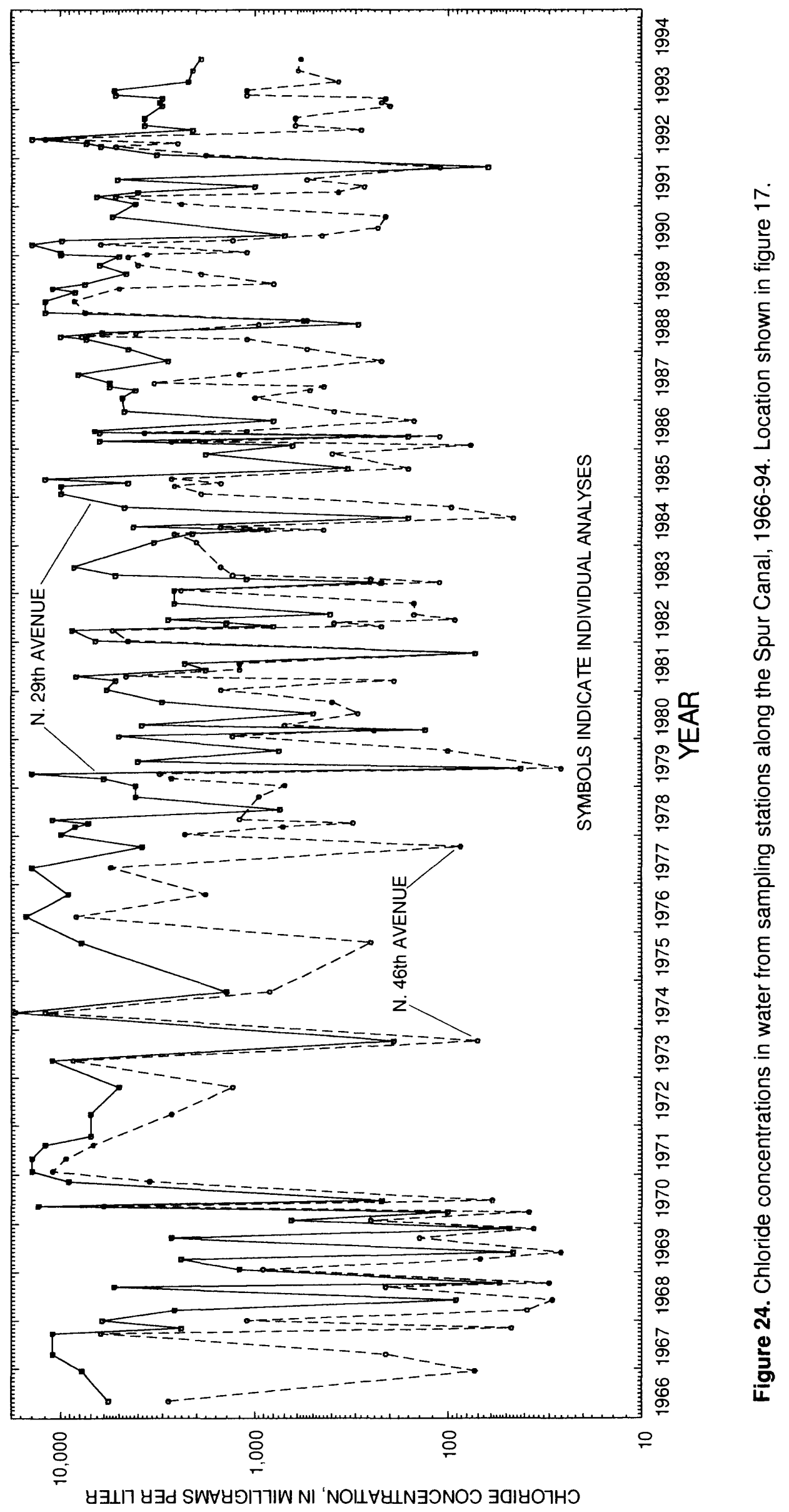

Progression of Saltwater Intrusion in Southern Coastal Broward County 47 
of data north and east of well G-1446. West of the Hollywood Canal, increasing chloride concentrations in water samples from well G-1237 and the continuing use of Dania supply wells S-2155 and S-2156 probably indicate that saltwater is intruding westward from the Hollywood Canal and southward from the Dania Cutoff Canal, but has not yet reached the supply wells.

The high salinity of water samples from S-830 (figs. 16 and 25) suggests a pattern of saltwater intrusion from the tidal Dania Cutoff Canal, as has been previously noted. Because of the threat of saltwater intrusion from the canal, observation wells were drilled near Broward County Utilities Well Field 3A (fig. 25). These wells began to provide water samples for chloride analysis in 1976 (Pitt, 1977). Water samples from well G-2260 (23 ft deep) in the well cluster closest to the Dania Cutoff Canal were fresh (fig. 26). However, water samples from well G-2261 $(60 \mathrm{ft}$ deep) had chloride concentrations greater than 100 $\mathrm{mg} / \mathrm{L}$ and water samples from well G-2262 $(88 \mathrm{ft}$ deep) were highly saline (chloride concentrations of about 1,200 mg/L). Because both wells are within the highly permeable pumping zone at some distance from the ocean, this is interpreted as indicating a pattern of saltwater intrusion from the canal. The sampling of these wells by the USGS was discontinued in 1982 , and the wells were destroyed during road improvements in 1985.

Farther south, and closer to the three original supply wells (fig. 25), water samples from wells G-2263 (23 ft deep) and G-2264 (203 ft deep) were fresh until sampling was discontinued in 1982-83. However, water samples from the pumping zone monitoring well $\mathrm{G}-2265$ (60 ft deep) rapidly increased in chloride concentration to nearly $1,000 \mathrm{mg} / \mathrm{L}$ (fig. 26), suggesting that the well field might be inducing intrusion from the canal in the highly permeable pumping zone. Pumping from the three nearby supply wells was later discontinued and the three monitoring wells were unintentionally destroyed during the construction for road improvement.

In the vicinity of the three newer supply wells, wells G-2271 (in 1977) and G-2291 (in 1979) were percussion driven to 165 and $160 \mathrm{ft}$, respectively, as water samples were collected at various depths (table 2). All water samples had chloride concentrations less than $25 \mathrm{mg} / \mathrm{L}$. Shallow and deep well pairs G-2267/ G-2268 (48 and $168 \mathrm{ft}$ deep) and G-2269/G-2270 (50 and $184 \mathrm{ft}$ deep) were constructed to monitor the quality of the ground water in the vicinity of the three remaining supply wells. The wells have produced water samples with chloride concentrations less than $100 \mathrm{mg} / \mathrm{L}$ of chloride. Except for twice yearly sampling at well G-2270, all ground-water quality monitoring in the vicinity of Broward County Utilities Well Field 3A since 1983 has been conducted by Broward County agencies.

North of the Dania Cutoff Canal, well G-2347 (fig. 17) was drilled by the dual-tube reverse air method in 1981 as a depth profile of chloride concentration was acquired. Although this well is in an area considered to be saltwater intruded, well G-2347 produced potable water samples to a depth of $110 \mathrm{ft}$ (table 2). Well G-1235, $213 \mathrm{ft}$ deep, continued to produce saline water samples (chloride concentrations in excess of $600 \mathrm{mg} / \mathrm{L}$ ) through 1977, and water samples from well G-854 have become progressively more saline since 1975 (chloride concentrations in excess of $2,000 \mathrm{mg} / \mathrm{L}$ ). However, the chloride concentrations of water samples from wells G-2129 (180 ft deep) and G-2130 (60 ft deep) have been less than $100 \mathrm{mg} / \mathrm{L}$ (fig. 16). Most likely, saltwater has intruded from the ocean, the tidal South Fork New River, and the tidal Dania Cutoff Canal. In an area surrounding well G-2347, there probably occurs a thick lens of freshwater that does not extend to the base of the Biscayne aquifer. Additional data collection would be required to confirm these conclusions.

Generally, the monitoring data are insufficient to define the transition zone between fresh and saltwater zones, even east of the Hallandale Well Field where the greatest density of monitoring wells with many years of record exists. It is noteworthy that vertical profiles of chloride concentration in the study area (table 2, wells G-2347, G-235 I A, and G-2621) show a convergence to a concentration significantly less than that of seawater (about $19,000 \mathrm{mg} / \mathrm{L}$ of chloride concentration) below a certain depth. This is consistent with Kohout's depiction of the gradient as being nearly horizontal below a certain depth (fig. 11), which might represent the retardation of the inland movement of saltwater by geologic deposits of low permeability below the Biscayne aquifer.

\section{NUMERICAL ANALYSES OF SALTWATER INTRUSION}

The field data have been used to describe the progressive movement, inland or seaward, of the saltwater front. The resulting interpretations can be used to guide efforts to describe the process of saltwater intrusion with numerical methods. The numerical simulation of the saltwater intrusion process is highly useful because it can: (1) help the analyst determine which of the various hydrologic properties 


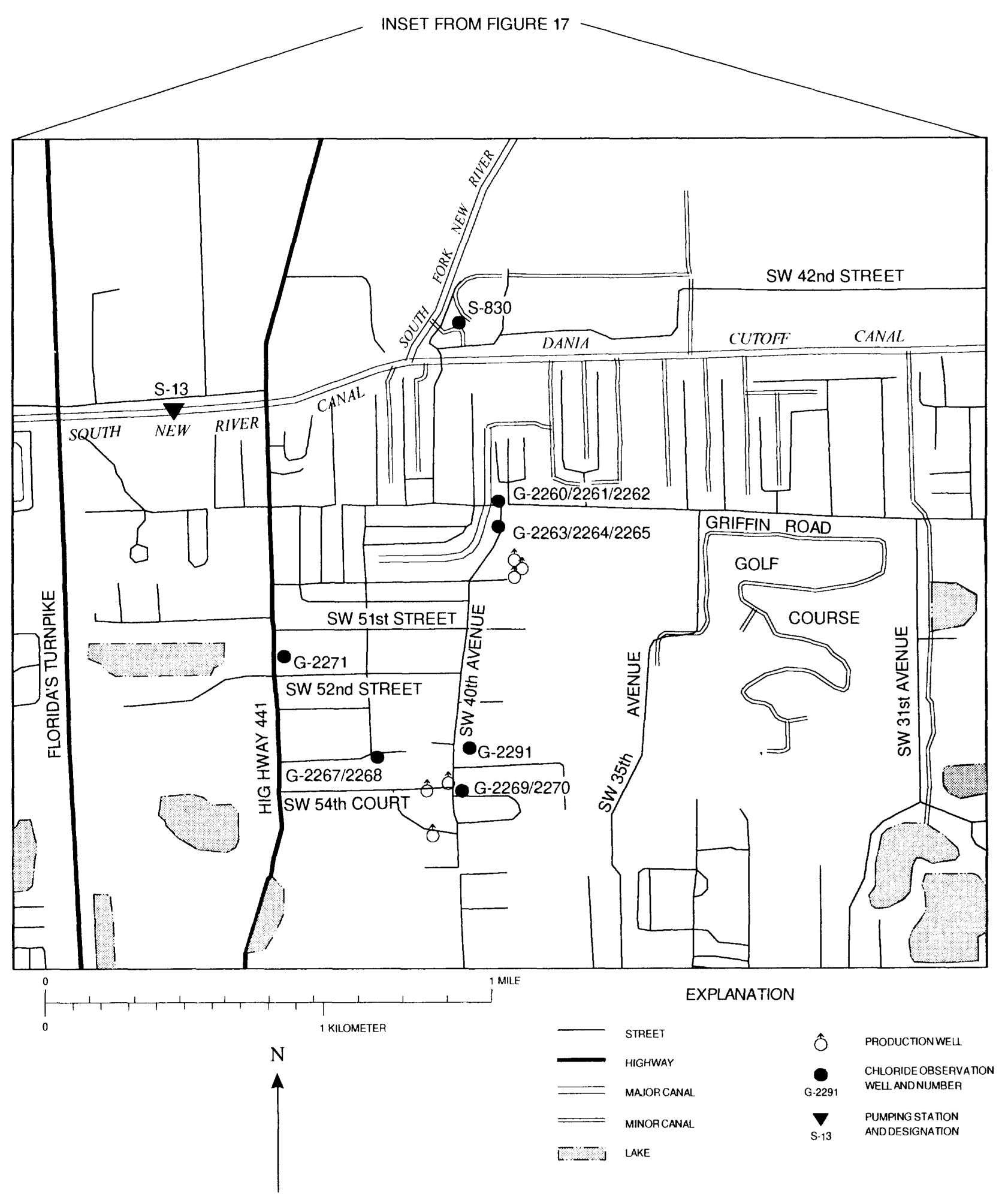

Figure 25. Locations of wells used for detecting and monitoring saltwater intrusion in the vicinity of Broward County Utilities Well Field 3A. 


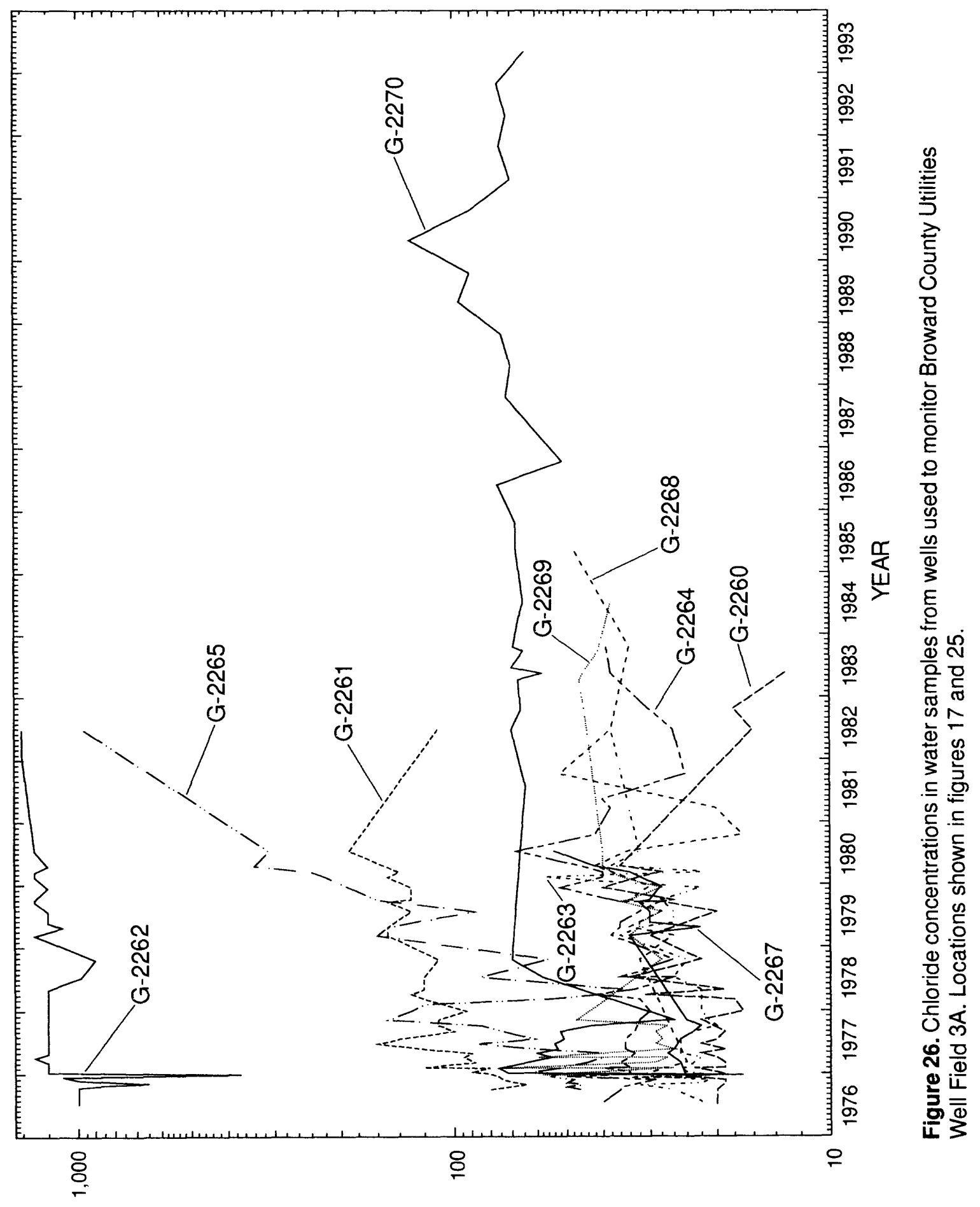

y $\exists \perp 17$ y 
characterizing the coastal subsurface environment and which water-management practices representing its use by man are dominant or significant in causing saltwater intrusion to occur, and (2) provide a simulator that will relate changes in water system management to the intrusion process. Two model codes were applied in the course of this study: the SHARP code, which simulates the position of the saltwater front as a sharp interface having no transition zone (a zone in which a gradational change between fresh and saltwater mineralization occurs), and the SWIP code, which simulates a two-fluid, variable-density system with a convective-diffusion approach that contains a representation of the transition zone.

The SHARP code is generally the easier of the two to apply and is computationally more efficient, but the transition zone is not represented. Aquifers are treated as single, vertically uniform layers separated by leaky confining layers, and the representational sophistication of the code (including types of boundaries, well descriptions, and types of sources and sinks) is, at present, limited. The SWIP code has more representational sophistication, uses a Fickian approach to represent the transition zone, and is fully three-dimensional. However, the SWIP code is computationally cumbersome when applied to problems of regional-scale solute transport, particularly those in which the scale of the vertical discretization is orders of magnitude less than that of the horizontal discretization. The latter difficulty is especially significant when a detailed description of vertical solute variation is desired, as when the process of vertically stratified movement of freshwater in contact with seawater is simulated.

In this study, each model was used for various specific aspects of the general simulation problem. The SHARP code was used first for a generalized areal simulation of the predevelopment position of the saltwater interface in the study area. Various parameters were varied in unsuccessful attempts to obtain a simulation consistent with available data, and the various simulations were compared with the head-interface relation predicted by the Ghyben-Herzberg relation. The available data apparently are in substantial disagreement with the Ghyben-Herzberg relation. Additional simulations with SHARP represented current conditions, including well-field pumping from the Biscayne aquifer, in the study area for a comparison with one of the simulated predevelopment interface positions.

A cross-sectional grid was subsequently designed for an application of SWIP to represent the same generalized aquifer represented in the SHARP simulation of the predevelopment interface position. This procedure facilitated a comparison of SHARP and SWIP solutions. The SWIP cross section was then modified to include vertical layering of hydraulic conductivity based on data acquired from previous studies. Again, parameters were varied in attempts to obtain a solution consistent with available data and to gain a theoretical understanding of the relation between the interface position and aquifer parameters and natural hydraulic stresses. The various results were compared with the head-interface relation predicted by the GhybenHerzberg principle. In further attempts to achieve a solution consistent with measured data, a study was made of simulated unsteady conditions occurring before convergence of the solution to an equilibrium interface position. Another SWIP cross-sectional grid with a representation of detailed layering of hydraulic conductivity was used for further study of the effects of hydraulic conductivity layering on the shape and position of the saltwater interface. This grid was also used for a study of the use of various vertical dispersion algorithms and corresponding differences in the position and structure of the various saltwater interfaces simulated. Only a brief discussion is included of the problems encountered in attempts to use SWIP to represent the saltwater interface three dimensionally. The model codes and the methodology and results of their application for analysis of the problem of saltwater intrusion are described in the following sections.

\section{Sharp Interface Representation}

The SHARP code simulates the flow of freshwater and saltwater separated by a sharp interface. A single-layer sharp interface model was documented by Mercer and others (1980). The present model (Essaid, 1990 ) is an improved version of the earlier model that uses a quasi three-dimensional approach to simulate saltwater intrusion in layered coastal aquifer systems by representing them as a sequence of aquifers separated by leaky confining layers. The single-layer representation remains available as a special case of the quasi three-dimensional approach.

The model solves separate vertically integrated flow equations for the freshwater and saltwater zones. The equations are coupled by the boundary condition for fluid pressure at the freshwater-saltwater interface. The vertically integrated equations for freshwater and saltwater flow are, respectively (Essaid, 1990): 


$$
\begin{gathered}
S_{f} B_{f} \frac{\partial \phi_{f}}{\partial t}+n \alpha \frac{\partial \phi_{f}}{\partial t}+\left[n \delta \frac{\partial \phi_{f}}{\partial t}-n(1+\delta) \frac{\partial \phi_{s}}{\partial t}\right]= \\
\frac{\partial}{\partial x}\left(B_{f} K_{f x} \frac{\partial \phi_{f}}{\partial x}\right)+\frac{\partial}{\partial y}\left(B_{f} K_{f y} \frac{\partial \phi_{f}}{\partial y}\right)+Q_{f}+Q_{l f}
\end{gathered}
$$

and:

$$
\begin{gathered}
S_{s} B_{s} \frac{\partial \phi_{s}}{\partial t}+\left[n(1+\delta) \frac{\partial \phi_{s}}{\partial t}-n \delta \frac{\partial \phi_{f}}{\partial t}\right]= \\
\frac{\partial}{\partial x}\left(B_{s} K_{s x} \frac{\partial \phi_{s}}{\partial x}\right)+\frac{\partial}{\partial y}\left(B_{s} K_{s y} \frac{\partial \phi_{s}}{\partial y}\right)+Q_{s}+Q_{l s}
\end{gathered}
$$

where:

$S_{f}$ and $S_{s}$ are freshwater and saltwater specific storages $\left(\mathrm{L}^{-1}\right)$

$B_{f}$ and $B_{s} \quad$ are thicknesses of the freshwater and saltwater zones (L)

$\phi_{f}$ and $\phi_{s} \quad$ are freshwater and saltwater heads (L)

$n$ is porosity

$\alpha$ is 1 for an unconfined aquifer and $\alpha$ is 0 for a confined aquifer

$\delta$ is $\gamma_{f} \gamma_{s}-\gamma_{f}$ where $\gamma_{f}$ and $\gamma_{s}$ are freshwater and saltwater specific weights; $\gamma_{f}$ and $\gamma_{s}$ have units of $\mathrm{PL}^{-3}$

$t$ is time

$K_{f x}$ and $K_{s x}$ are freshwater and saltwater hydraulic conductivities in the $\mathrm{x}$-direction $\left(\mathrm{LT}^{-1}\right)$

$K_{f y}$ and $K_{s y} \quad$ are freshwater and saltwater hydraulic conductivities in the y-direction $\left(\mathrm{LT}^{-1}\right)$

$Q_{f}$ and $Q_{s} \quad$ are freshwater and saltwater source or sink rates per unit area $\left(\mathrm{LT}^{-1}\right)$

$Q_{\text {If }}$ and $Q_{l s} \quad$ are freshwater and saltwater leakage rates per unit area through confining lay$\operatorname{ers}\left(\mathrm{LT}^{-1}\right)$

$P, L, T$ indicate pound-force, length, and time units

The coupled parabolic partial differential equations (1) and (2) must be solved simultaneously for freshwater and saltwater heads $\left(\phi_{f}\right.$ and $\left.\phi_{s}\right)$. The interface elevation $(h)$ is then:

$$
h=(1+\delta) \phi_{s}-\delta \phi_{f}
$$

Where only freshwater or saltwater is present, flow is described by a single equation without the terms that describe change in storage due to interface movement.

The flow equations are discretized by an implicit finite-difference scheme and the solution is by the Strongly Implicit Procedure (SIP). The model is quasi-three-dimensional in that it can represent a system of aquifers separated by semiconfining layers. The uppermost aquifer can be unconfined and receive areally distributed recharge. Aquifer and confining layer properties can vary areally. The code contains special procedures for determining the position of the tip and toe of the saltwater front and for describing interaquifer leakage when one aquifer contains saltwater and the other contains freshwater.

Because the saltwater intrusion process is slow, the movement of saltwater to an equilibrium position takes several years to thousands of years depending on the properties of the subsurface environment. Accordingly, complex systems of equations must be solved numerically for numerous time steps comprising long simulation time periods. This means that run times may be long, taxing available computational resources and causing delays in obtaining simulation results.

"Simulation time" refers to the length of the period of time required for the process being simulated to occur in nature. "Run time" is the actual clock time required for running the simulation on the computing equipment utilized.

When using the SHARP model, a computational stratagem can be employed to greatly shorten simulation times and run times in cases where a steady-state solution, the determination of an equilibrium position of the interface under a specified set of conditions, is sufficient as an objective of analysis. The equilibrium position can be simulated in a few timesteps of relatively short duration if the aquifer storage coefficients and the effective porosity for the freshwater and saltwater zones are set to artificially small numbers that have no effect on the steady-state solution.

The SHARP code was used for estimates of the likely interface position under predevelopment conditions, under recent conditions as affected by watermanagement control, and as affected by the Hallandale Well Field, which is centrally located in the study area. Analyses were necessarily of a generalized nature because of limitations on the representational capability of the model code. Some SHARP model parameter specifications were chosen to remain constant in all analyses made with the model. Other parameter specifications were varied as necessary to represent the various conditions analyzed. 


\section{Grid Design and Parameter Value Assignments}

An areal grid design, rather than a cross section, was employed for SHARP simulations because the current flow system in the aquifer within the study area did not display any dimensional uniformity and because analyses of the effects of well-field pumping were planned. The region bounded by Highway 441 on the west, the Dania Cutoff Canal on the north, the Snake Creek Canal on the south, and the coast of the Atlantic Ocean on the east was generalized as a rectangular area with an east-west dimension of $30,000 \mathrm{ft}$ and a north-south dimension of $38,000 \mathrm{ft}$. The $30 \times 38$ grid of blocks with a uniform dimension of $1,000 \mathrm{ft}$ was expanded with the addition of five additional columns to represent the extension of the Biscayne aquifer offshore to its subcrop at the Atlantic Shelf (fig. 27). The east-west dimensions of these columns, in west to east order, were $4,400,1,050,2,150,3,100$, and $1,750 \mathrm{ft}$, and the north-south dimension of each cell in the columns was $1,000 \mathrm{ft}$. The column widths were chosen so that specified ocean depths of 10,17, 20,37 , and $43 \mathrm{ft}$, respectively, would accurately represent the bathymetry of the offshore section. The eastwest dimensions and depths were based on an inspection of nautical chart no. 11467 prepared by NOAA and made available to the public in July 1982. The specified depths were those of the ocean bottom east of the Hallandale Well Field, but were also representative of the entire length of coast in the modeled area because ocean depth profiles are nearly uniform in this region.

On the basis of data describing the thickness of the Biscayne aquifer (figs. 4 and 5 and app. 3), the base of the Biscayne aquifer was represented as two platforms sloping seaward with a sharp increase in depth separating them at about two-thirds the distance between Highway 441 and the coast and about $1,750 \mathrm{ft}$ east of the Hallandale Well Field (fig. 28). It is at about this location on the east-west sections through southern Broward County that Fish (1988, figs. 17 and 18) indicates the occurrence of substantial intervals of solution porosity in the Tamiami Formation that are a vertical extension of the Biscayne aquifer. The cores obtained at test holes G-2610 and G-3472 (figs. 4 and 5 ), eastward of Fish's cross sections, also show this deepening of the aquifer. On the basis of Fish's work, the base of the Biscayne aquifer is assumed to coincide with the base of the Pleistocene Formations and to slope downward toward the east from $120 \mathrm{ft}$ at Highway 441 to $140 \mathrm{ft}$ just west of the east-west location where the Tamiami Formation solution porosity occurs. From the latter location, where the bottom of the aquifer is assumed to occur at about $300 \mathrm{ft}$ within the underlying Tamiami Formation, the base of the aquifer slopes downward toward the east to about 360 $\mathrm{ft}$ at the coast. There are no data to substantiate the latter depth, although core data from G-2610 indicate that solution porosity extends at least to $273 \mathrm{ft}$. The slope of the base of the aquifer is assumed to extend eastward to the undersea outcrop at the edge of the Atlantic Shelf where the base of the aquifer would be at about $450 \mathrm{ft}$. This representation of the aquifer constitutes an assumption that a primary discharge area for the freshwater system occurs somewhere offshore. There are no known data to confirm or refute this assumption or to verify the assigned depths, but both assumptions were required to postulate a conceptual model for simulation analyses.

The hydraulic conductivity of the aquifer was assumed to be horizontally isotropic throughout the modeled area and to have a value of $10,000 \mathrm{ft} / \mathrm{d}$. Because SHARP treats the aquifer as a two-dimensional horizontal layer, it was not possible to represent in the model the layers of relatively low permeability that occur near the surface. The SHARP runs were steady-state simulations of the equilibrium interface position using annual averages for boundary conditions and atmospheric stresses. Therefore, boundary conditions for head along the western, northern, and southern boundaries were specified as constant in time, but were varied as needed in individual analyses of different sets of conditions, as will be described presently. Boundary heads along the coast of the Atlantic Ocean were specified to be constant at $0.75 \mathrm{ft}$ above sea level in all analyses, based on the analysis of long-term records of tidal stations (table 1). The initial head in the interior of the grid was assigned a uniform value of $3 \mathrm{ft}$.

In a previous study that included the simulation of flow and transport in the Biscayne aquifer in southern Dade County (Merritt, 1996b), the average ratio of estimated evapotranspiration to rainfall was 92.4 percent over a 45 -year period. On this basis, the aquifer was assumed to have a net recharge of 7.6 percent of the southeastern Broward County annual rainfall, or $4.7 \mathrm{in} / \mathrm{yr}$ (inches per year) in initial runs. However, southern Dade County is largely wetlands, in which the water table is close to the surface. The study area, in contrast, is land of higher elevation so that the rate of evapotranspiration is lower. Later analyses with the SWIP code simulated net recharge rates of about 12 in/yr. Therefore, SHARP analyses were rerun with specified net recharge rates of $12 \mathrm{in} / \mathrm{yr}$. Results illustrated in figures are based on this latter value. The maximum change in the depth of the interface resulting from the change in the net recharge specification was less than $10 \mathrm{ft}$. 

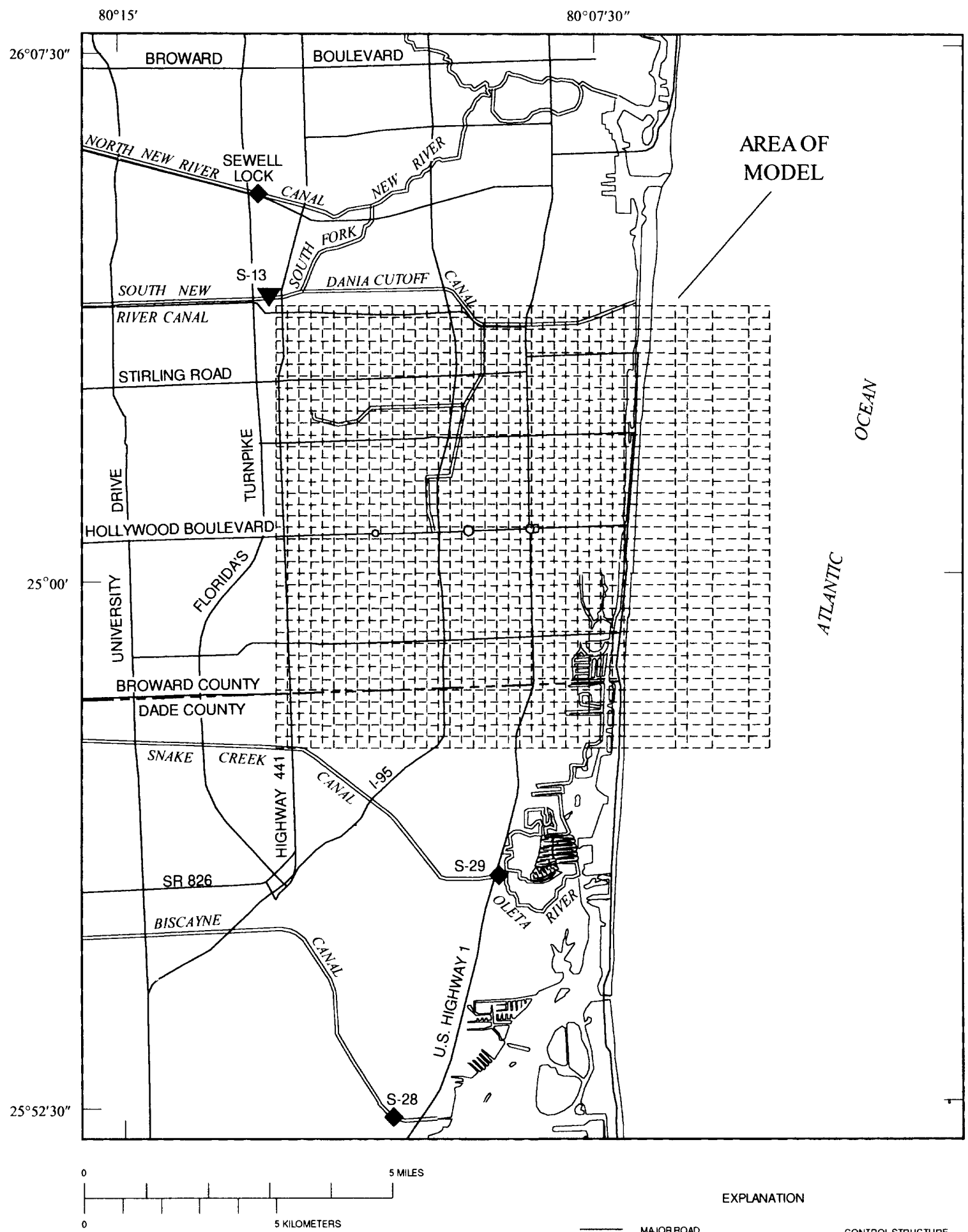

EXPLANATION

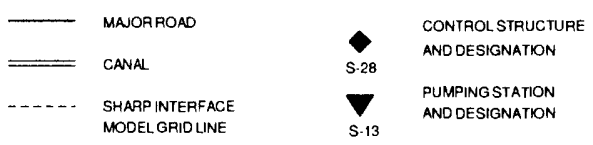

Figure 27. Spatial discretization and model boundaries used for analysis of saltwater intrusion with the sharp interface model. North-south and onshore east-west grid spacing is 1,000 feet; offshore east-west grid spacing is $4,400,1,050,2,150,3,100$, and 1,750 feet, respectively. 


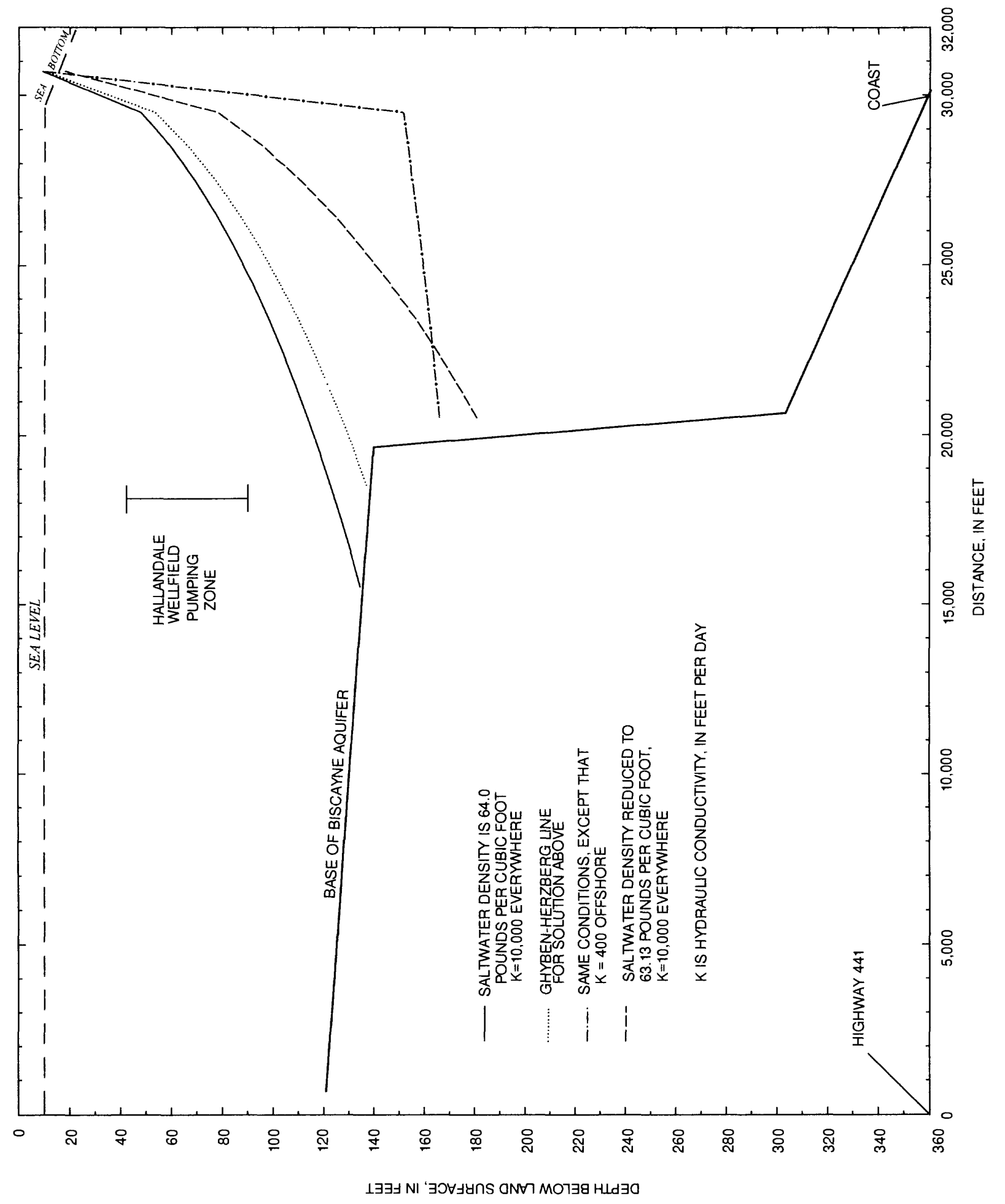

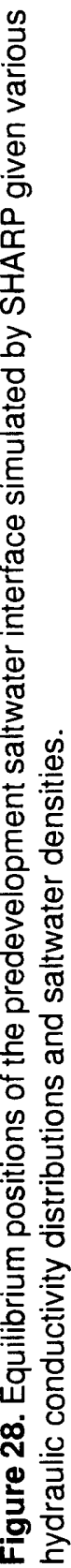


In all analyses, the freshwater was assigned a density (specific weight or weight density) of $62.26 \mathrm{lb} /$ $\mathrm{ft}^{3}$, considered representative of freshwater in the warm surficial aquifer of southern Florida. Seawater density was assumed to be $64.0 \mathrm{lb} / \mathrm{ft}^{3}$. The saltwaterzone density was varied in some analyses. The viscosities of freshwater and seawater were assumed to be equal at $0.98 \mathrm{cp}$ (centipoise), or $2.05 \times 10^{-5} \mathrm{lb}-\mathrm{s} / \mathrm{ft}^{2}$ (pound-second per square foot) and were not varied in any of the simulations. This is the value used in later SWIP runs for water with a temperature of $70^{\circ} \mathrm{F}$.

The maximum number of iterations per timestep was specified to be 150 , and the interface was considered fixed after 50 iterations. The criteria for convergence closure and steady-state closure (Essaid, 1990) were both $10^{-6} \mathrm{ft}$. The relaxation factor was 0.80 . The initial timestep was 1 day and a time-step multiplication factor of 1.5 was used for subsequent time steps. For steady-state simulations, storage coefficients for the freshwater and saltwater zones were set equal to $10^{-9}$ and effective porosity was set equal to 0.0001 . These values are not realistic, but, as noted previously, this is a device used to bring about fast convergence to a steady-state solution.

\section{Simulation of Predevelopment Conditions}

Although no data exist to describe the saltwater interface in the study area before development, it is of interest to use the SHARP model to estimate the location of the predevelopment interface in order to better understand the effect of human activities on the interface position and to determine if the model simulates a position that is consistent with later data. Part of the approach taken was to assume that natural groundwater flow throughout the area modeled occurred uniformly in the eastward direction toward tidal discharge areas offshore. As previously noted, no data are available to support any hypotheses about the direction of predevelopment ground-water flow or the distance to offshore discharge areas.

The effect of the South Fork New River in lowering heads to the north of the modeled area in predevelopment times was ignored, as was the similar effect of the Oleta River to the south. Neglecting the river effects are probably good assumptions, as the shallow streams probably had only a highly localized hydraulic influence on the highly permeable Biscayne aquifer. The main tidal part of the South Fork New River is about $3.75 \mathrm{mi}$ north of the northern boundary of the grid, and only the uppermost reach of the stream touches the northwestern corner of the grid boundary (fig. 27). The Oleta River only reaches inland about
$2 \mathrm{mi}$ and is more than $3.5 \mathrm{mi}$ south of the southern boundary of the grid. Therefore, the direction of predevelopment ground-water flow in and near the study area was probably not strongly influenced by the natural streams, except in their immediate vicinity.

The Hallandale Well Field is about $12,000 \mathrm{ft}$ west of the coast, and its position and the vertical interval used by the six supply wells in the main well field at the water-treatment plant is shown in figure 28. Because the position of the interface east of the Hallandale Well Field has approximately been known since 1969 , results from the simulation of predevelopment conditions would be invalid if the simulated predevelopment position of the interface were landward (west) of the earliest known position at Hallandale. The most definitive data were obtained during the drilling of well G-2328 in the Hallandale Well Field by the dual-tube reverse air method in 1981, when water samples collected at 10 -ft intervals to a depth of $300 \mathrm{ft}$ below land surface had chloride concentrations that did not exceed $260 \mathrm{mg} / \mathrm{L}$. This was 68 years after water management for flood control began in the region and 29 years after the Hallandale Well Field began pumping. As previously noted, the average water level in well G-1472, just east of the well field, was between 1.6 and $1.7 \mathrm{ft}$ above sea level between 1970 and 1994 (table 1).

The predevelopment annual average head along the western boundary (at the present location of Highway 441) was estimated to be $5 \mathrm{ft}$ above sea level (table 1). Because there was no basis for an estimate of heads along the northern and southern boundaries, an initial run was made in which the heads were specified as varying linearly from Highway 441 to the coast. Initially, north-south nonuniformities in the east-west head profile and the depth of the interface were simulated because heads on the northern and southern boundaries were either too high or too low. When the heads were too low, part of the simulated net atmospheric recharge to the modeled region discharged out across the northern and southern boundaries, violating the assumption of uniform easterly flow toward offshore discharge locations. When the heads were too high, the simulated net recharge to the modeled area was insufficient to prevent simulated ground-water flow into the modeled area from across the northern and southern boundaries.

To obtain a uniform east-west flow field, the head specifications along the northern and southern boundaries were adjusted. The method of adjustment was to use the heads simulated for the center row of the grid (the one least influenced by the boundary specification) as a new northern and southern boundary 
condition. This process was repeated iteratively three to four times until the simulated heads and their eastwest head variation were approximately uniform in the north-south direction and only flow eastward toward the ocean was simulated.

In the first analysis, the aquifer was assumed to have a uniform hydraulic conductivity of $10,000 \mathrm{ft} / \mathrm{d}$ and the density of seawater was $64.0 \mathrm{lb} / \mathrm{ft}^{3}$. The predevelopment sharp interface (fig. 28) is simulated as being located below the main well-field pumping zone at about $127 \mathrm{ft}$ below land surface, which is inconsistent with the observation that water samples from well G-2328 were fresh to $300 \mathrm{ft}$ after decades of water management and well-field pumping. The GhybenHerzberg line ( 40 times the simulated freshwater head) is located below the pumping wells at $142 \mathrm{ft}$ below land surface (fig. 28), which is slightly below the simulated sharp interface. The simulated steadystate head at the location of the Hallandale Well Field is about $3.5 \mathrm{ft}$ above sea level. The interface reaches sea bottom just east of the coastline, implying that the coastal freshwater discharge location is just slightly offshore. This simulation required eight timesteps and a total simulation time of 17.1 days to converge to steady state. The first timestep required 72 iterations to converge, and the seventh timestep required seven iterations to converge.

In an attempt to improve the simulation of predevelopment conditions, it was hypothesized that the hydraulic conductivity was much lower in the offshore grid cells (fig. 27), which lay underneath the Atlantic Ocean between the coast and the Atlantic Shelf. Eastward flow to an offshore discharge area was still assumed in this modified conceptual model, however. A change in hydraulic conductivity within the aquifer could occur as a result of some type of facies change in rock type that would result in fewer solution features occurring in offshore deposits. Such a facies change could represent the result of depositional or diagenetic processes such as the prehistoric occurrence of low-energy offshore environments that would result in the deposition of fine sediments, or the lack of any processes causing solution during geological periods following deposition, or the later infilling of solution features with sand or silt. The hypothesis is not supported by the best available data, the cores from wells G-2610 and G-3472, which show solution features throughout the intervals cored at the present-day coast. However, in Palm Beach County to the north of Broward County, such a facies change does occur, and the "Turnpike aquifer" is bounded on the east near the coast by deposits lacking the solution features of the aquifer (Swayze and Miller, 1984).
To perform the analysis, the hydraulic conductivity of the offshore grid cells was changed to $400 \mathrm{ft} / \mathrm{d}$. (A value of $40 \mathrm{ft} / \mathrm{d}$ was also used, but the model would not simulate eastward flow with Highway 44 I [western boundary] heads of $5 \mathrm{ft}$.) Results of the analysis (fig. 28) show the sharp interface to intersect the base of the Biscayne aquifer $170 \mathrm{ft}$ below land surface at a point slightly less than 2,000 ft east of the well field. Because the model does not represent vertically adjacent layers of lower permeability or simulate the interface within confining layers, the position of the interface underneath the well field was not simulated. When well G-2351A was drilled 1,900 ft east of the main well field in 1980, 28 years after well-field pumping began, the transition to saltwater occurred between 175 and $200 \mathrm{ft}$ below land surface (table 2). Therefore, this simulated position is also not consistent with the available data.

A further attempt to obtain a simulation of predevelopment conditions was based on a consideration of the density of the water within the transition zone separating freshwater and seawater. The depiction of the interface near Cutler in Dade County (fig. 11), based on analysis (Kohout, 1960) of water samples from several groups of wells, indicates that the transition zone below $60 \mathrm{ft}$ is dispersed over a distance of nearly $2,000 \mathrm{ft}$. Therefore, it was hypothesized that a sharp interface separated freshwater from water with a density less than that of seawater. As a conservative test of this hypothesis, the saltwater body was assigned a density $\left(63.13 \mathrm{lb} / \mathrm{ft}^{3}\right)$ greater than freshwater by only 50 percent of the difference in density between freshwater and seawater. The aquifer was assigned a uniform hydraulic conductivity of $10,000 \mathrm{ft} / \mathrm{d}$ (including offshore grid cells). The simulation results (fig. 28) show the interface to intersect the base of the Biscayne aquifer at $185 \mathrm{ft}$ below land surface at a point about $2,000 \mathrm{ft}$ east of the main well field. This is more realistic than previous results but is still not fully consistent with available data.

Sensitivity analyses were performed to determine whether errors in one or more of the estimated parameter values describing hydraulic properties of the aquifer might have a significant effect on the simulation. In one analysis, the bottom of the aquifer was assumed to vary linearly from $120 \mathrm{ft}$ below land surface at Highway 441 to $300 \mathrm{ft}$ at the coast. The bottom slope was extrapolated to the subsea outcrop. The effect on the simulated interface elevation was negligible. In another sensitivity test, the hydraulic conductivity of the aquifer was reduced uniformly by 25 percent, to $7,500 \mathrm{ft} / \mathrm{d}$. Again, the effect on the simulated interface, a rise of about $1 \mathrm{ft}$, was negligible. 
The analyses with the SHARP code have failed to adequately simulate a position of the predevelopment interface consistent with available data. Whether the postulated conceptual model of uniform eastward flow toward offshore discharge areas is incorrect or there is another explanation is not presently known.

\section{Simulation of Recent Conditions}

It is of significant interest to use the SHARP code to compare a simulated position of the saltwater interface under recent (1993) conditions with a simulated predevelopment position. The predevelopment simulation used for the comparison was the one in which the specified saltwater density $\left(63.13 \mathrm{lb} / \mathrm{ft}^{3}\right)$ was only greater than that of freshwater by 50 percent of the difference between freshwater and seawater because that simulation produced the depiction of predevelopment conditions considered to be most realistic. The hydraulic conductivity was specified as being spatially uniform at a value of $10,000 \mathrm{ft} / \mathrm{d}$. This is, therefore, a hypothetical simulation, and the use of this model version for a simulation of the effects of present-day boundary conditions and well-field pumping cannot be considered an accurate simulation of the actual interface location under modern conditions but can provide a qualitative insight into the effects of these influences on the position of the saltwater front. The analysis depends, as before, on the validity of the conceptual model, which assumes a uniformly permeable aquifer that extends eastward to offshore discharge areas.

Recent average water-table altitudes at wells G-1223 and G-1225 (table 1) were used to assign a uniform boundary value for head along the western (Highway 44l) boundary. A value of $2.4 \mathrm{ft}$ was selected. The northern boundary coincided with the location of the Dania Cutoff Canal, which is tidal throughout its length. The reach of the South New River Canal below S-13 (fig. 2) is open to the Dania Cutoff Canal and, therefore, also tidal. The average stage below S-13 is $0.75 \mathrm{ft}$ (table 1), which is the same as the average stages at tidal gaging stations along the Atlantic Coast. A value of $0.75 \mathrm{ft}$ was the head value assigned to the northern boundary. It was not possible to represent the hydraulic influence of the Hollywood and Spur Canals because the present version of SHARP does not include the capability to represent canals.

The western end of the southern boundary of the grid (fig. 27) touched the Snake Creek Canal less than $4 \mathrm{mi}$ above S-29. The average stage in the canal above S-29 was about $2.0 \mathrm{ft}$ above sea level. Eastward toward the coast, there are no wells near the model boundary where the water-table altitude has been continuously measured, so that it was necessary to estimate the average water-table altitude. It was assumed that the average water-table altitude for the southern boundary declined linearly from $2.0 \mathrm{ft}$ at the western end to $0.75 \mathrm{ft}$ at the coast. The assignment of values to the southern boundary was consistent with water-table altitudes shown on unpublished USGS water-table maps of southeastern Broward County.

When these modified boundary conditions were entered into the SHARP simulation described above with no other changes, the equilibrium position of the sharp interface separating freshwater and water of half seawater salinity was located below the Hallandale Well Field pumping zone at about $115 \mathrm{ft}$ below land surface (fig. 29). This position is farther inland and substantially higher in altitude than the simulated predevelopment position, and is generally indicative of the degree of saltwater intrusion that could have occurred as a result of the construction of the canal system for water management and drainage, subject to reservations about the ability to reconstruct predevelopment conditions. Because of the generalizing assumptions on which this model was based, however, it should not be considered a realistic simulation of existing or potential conditions.

To gain an understanding of the possible effect on the interface position of well-field pumping, the SHARP run was modified further by the specification of pumping at the east-west location of the Hallandale Well Field (fig. 27, row 30, column 19). The specified rate was $5.47 \mathrm{Mgal} / \mathrm{d}$ or $8.73 \mathrm{ft}^{3} / \mathrm{s}$ (cubic feet per second), the average pumping rate of the well field furing its peak years (1979-87). The result (fig. 29) was a further rise in the interface altitude that was especially pronounced at the simulated well-field location. The simulated altitude of the interface, given the specified rate of pumping, would have caused saltwater upconing into pumping wells. However, it is noted once again that the simulation, not including the effects of other well fields or the Hollywood Canal, is not a realistic simulation of the saltwater interface, which is actually located at some distance seaward, but qualitatively demonstrates the degree to which pumping of the Hallandale Well Field could cause additional saltwater intrusion. In these hypothetical simulations, the greatest degree of regional saltwater intrusion was shown to be the result of the lowering of the regional water table from its assumed predevelopment altitude. The well-field pumping is simulated as being a secondary effect sufficiently large to cause saltwater intrusion into a well field already in close proximity to the interface as a result of the lowering of the regional water table. 


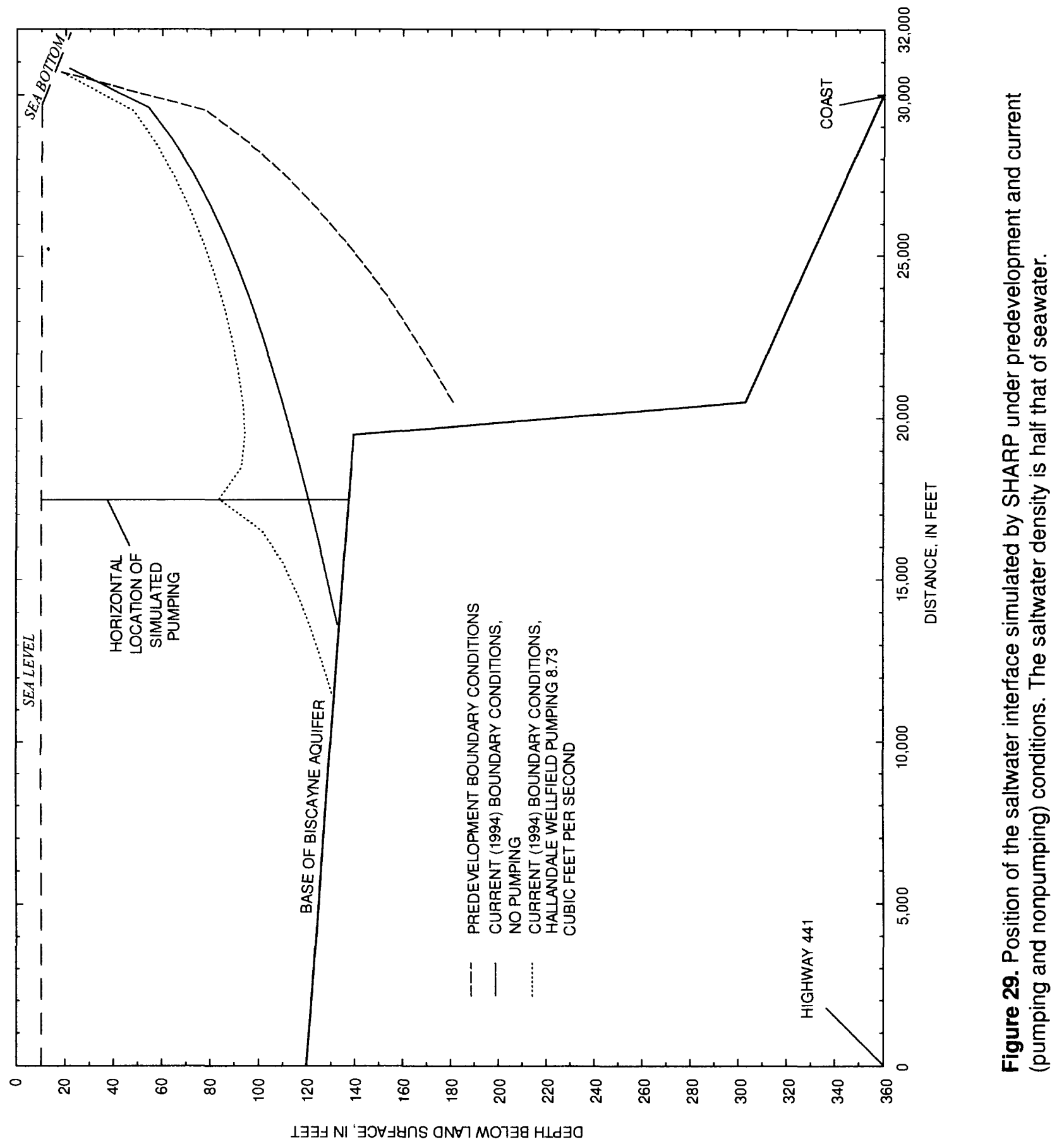


The capability of the SHARP code to provide a description of the saltwater interface regionally is illustrated (fig. 30) with lines showing the simulated equilibrium position of the saltwater toe at the base of the seaward-sloping Biscayne aquifer. The lines are constructed from SHARP output data showing the boundary between cells containing saltwater and freshwater and cells containing only freshwater. The three cases shown are the hypothetical simulations in which the saltwater body was represented as having half the salinity of seawater, and represent predevelopment conditions and recent conditions with and without pumping of the Hallandale Well Field. As previously noted, the influence of the Hollywood Canal and other well fields was ignored, and boundary conditions in the predevelopment simulation were manipulated so that simulated flow would be uniform in the seaward direction. A predevelopment northsouth interface line is the result. When recent boundary conditions were represented, the simulated position of the saltwater toe was significantly farther inland. The interface position clearly shows the influence of drainage by the tidal Dania Cutoff Canal to the north and the effect of the estimated boundary conditions along the southern boundary.

When Hallandale Well Field pumping is represented, the change in the saltwater toe position is depicted as being slight and confined to a small area near the well field. This limited effect is a result of the high hydraulic conductivity of the Biscayne aquifer. It is noted again that the location of the interface is not simulated realistically by the SHARP code, even using the modified saltwater density value, but the response of the position of the saltwater front to hydrologic controls within the modeled area and their temporal variation is clearly demonstrated in a qualitative way.

\section{Diffuse Interface Representation}

As previously noted, adjacent subsurface bodies of freshwater and saltwater are separated by a transition zone containing a mixture of the two waters. In this transition zone, the composition of the mixture varies from nearly that of freshwater near the body of unmixed freshwater to nearly that of saltwater near the body of unmixed saltwater. To study the effect of the mixing zone on the position and movement of the saltwater front, and to construct a more realistic model of the front, a code capable of simulating the transition zone was required. By assuming boundary conditions and hydrologic characteristics to be the same as specified previously in the SHARP simulations, it was also possible to compare the sharp and diffuse interface approaches. The diffuse interface code selected for the analysis of saltwater intrusion in this study was SWIP.

The SWIP code was developed by INTERCOMP Resource Development and Engineering, Inc. (1976), under sponsorship of the USGS and later modified for the USGS by the same firm renamed INTERA Environmental Consultants, Inc. (1979). Despite its intended use as a special package for waste-injection problems, the SWIP code received wider use within the USGS as a general-purpose three-dimensional simulator of solute- and thermal-energy transport in ground water. The code has been adapted for special purposes by various non-USGS public and private organizations. Some parts of the code have been used, with adaptation, as modules within a more recently developed USGS three-dimensional solute-transport code (Kipp, 1987).

The forms of the flow and solute-transport equation solved by SWIP are as follows:

$$
\underset{\nabla}{\nabla} \underset{\sim}{K}(\underset{\sim}{\nabla} p-\rho \underset{\sim}{\nabla} z)=\frac{\partial}{\partial t}(\varnothing \rho)+q^{\prime}
$$

and

$$
\begin{aligned}
& \underline{\nabla} \bullet C \underset{\sim}{K}(\underline{\nabla} p-\rho \underline{\nabla} z)+\underline{\nabla} \bullet(\rho \underset{\sim}{E}) \cdot \underset{\sim}{\nabla} C= \\
& \frac{\partial}{\partial t}(\rho \varnothing C)+\Sigma q_{i} C_{i}
\end{aligned}
$$

where:

$K \quad$ is a hydraulic conductivity tensor $(\mathrm{L} / \mathrm{T})$

$p \quad$ is fluid pressure $\left(\mathrm{P} / \mathrm{L}^{2}\right)$

$\rho \quad$ is weight density $\left(\mathrm{P} / \mathrm{L}^{3}\right)$

$z \quad$ is the vertical position coordinate $(L)$

$\varnothing \quad$ is effective porosity (unitless)

$t \quad$ is time (T)

$q^{\prime} \quad$ is a sum of sources and sinks of fluid $\left(\mathrm{P} / \mathrm{L}^{3} \mathrm{~T}\right)$

$C$ is a unitless fraction ranging from 0 to 1 that represents the relative concentration of one of two fluids in a mixture

$q_{i} \quad$ is a source or sink of fluid with concentration $C_{i}(\mathrm{P} /$ $\mathrm{L}^{3} \mathrm{~T}$ )

$\mathrm{P}, \mathrm{L}$, and $\mathrm{T}$ indicate pound-force, length, and time units. $\underset{\nabla}{\bullet} \underset{\sim}{A}$ denotes a divergence operator applied to some vector or tensor $\underset{\sim}{A}$, and $\underset{\sim}{\nabla} \underset{\sim}{B}$ denotes the vector gradient of some vector $\underset{B}{ }$. The forms of the diagonal 

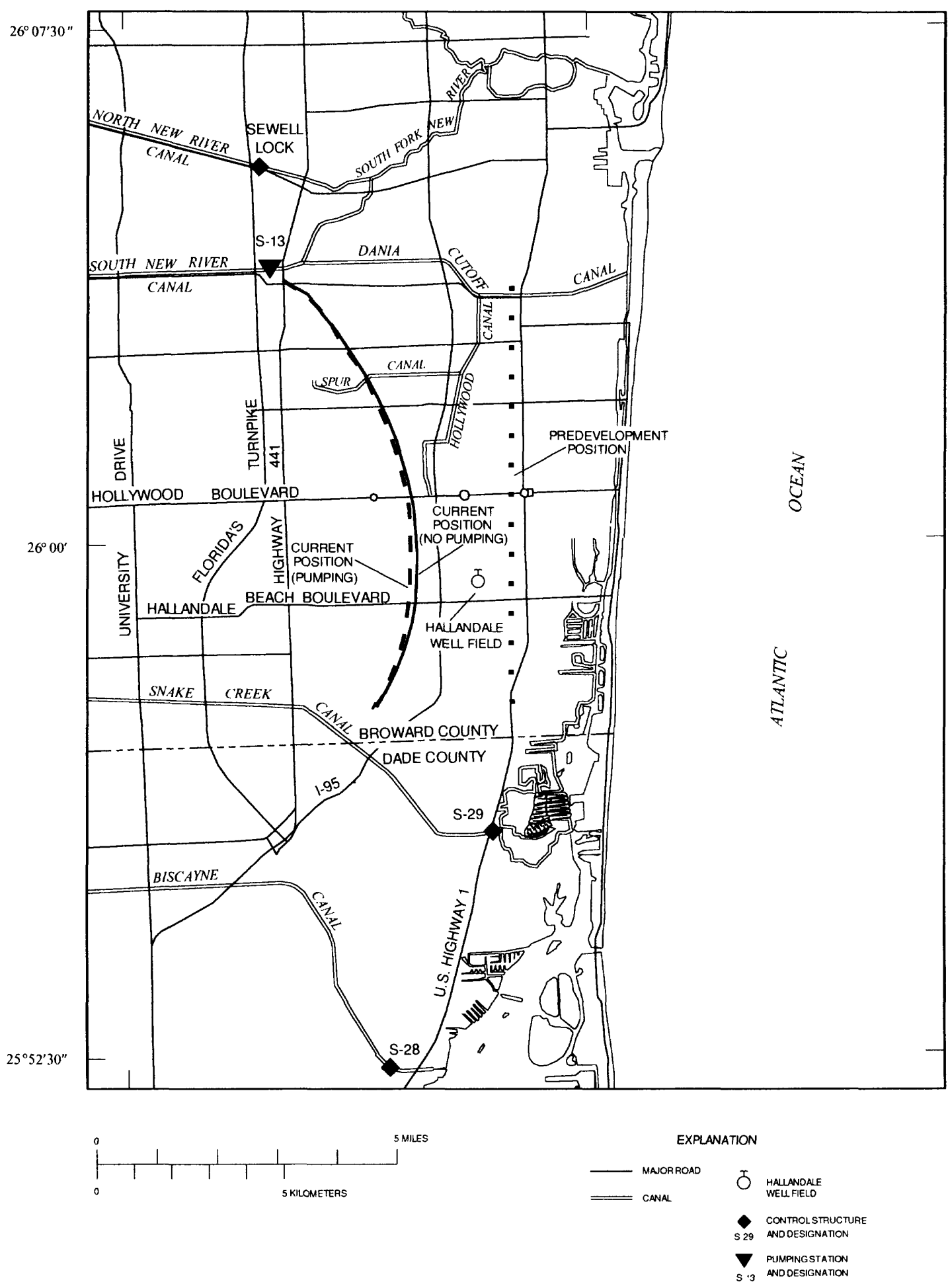

Figure 30. Hypothetical saltwater toe positions simulated by SHARP under predevelopment and current conditions with and without Hallandale Well Field pumping. Actual field conditions are not represented by these simulations. 
$\left(E_{i i}\right)$ and off-diagonal $\left(E_{i j}\right)$ elements of the hydrodynamic dispersion tensor $\underset{\sim}{E}$ are as given by Kipp (1987):

$$
\begin{aligned}
& E_{i i}=\alpha_{l} \alpha_{1} \frac{V_{i}^{2}}{V}+\alpha_{f} V+D_{m} \\
& E_{i j}=\left(\alpha_{l}-\alpha_{l}\right) \frac{V_{i} V_{j}}{V}
\end{aligned}
$$

where:

$E_{i i} \quad$ is the degree of dispersion in the $i t h$ coordinate direction related to the velocity of flow $\left(V_{i}\right)$ in that coordinate direction $\left(\mathrm{L}^{2} / \mathrm{T}\right)$

$E_{i j} \quad$ is the degree of dispersion in the $i t h$ coordinate direction related to the velocity of flow $\left(V_{j}\right)$ in the $j t h$ coordinate direction $\left(\mathrm{L}^{2} / \mathrm{T}\right)$

$\alpha_{l}$ and $\alpha_{t}$ are longitudinal and transverse dispersivities (L)

$V \quad$ is the magnitude of the velocity vector in the principal direction of flow $(\mathrm{L} / \mathrm{T})$

$D_{m} \quad$ is molecular diffusivity $\left(\mathrm{L}^{2} / \mathrm{T}\right)$

The dispersion tensor operates on the concentration gradient vector $\nabla C$, as implied by equation 5 .

Solving the flow equation in terms of fluid pressure enables the model to simulate flows caused by density gradients. The model accounts for fluid density and viscosity dependence on temporal changes in pressure, temperature, and solute concentration. Solution of the equations for ground-water flow with solute and thermal-energy transport is by finite-difference techniques in which backward and central differencing in time and space are available as user options for solution of the equations for solute and thermal-energy transport. A Gaussian elimination technique and an iterative method are used to reduce the solution matrix size that results from the coupling of the three equations. The aquifer simulated may be fully confined or have a free surface, and the equations may be solved in either Cartesian or cylindrical coordinates.

A solute fraction value $(C)$ is used to represent the proportion of each of two fluids in a mixture that varies both spatially and temporally. Any fluids present within the aquifer or entering the aquifer during simulations are considered to be mixtures of the two fluids as described by the appropriate specification of $C$ values. The extreme values of $C(0$ and 1$)$ were used in this study to represent freshwater and saltwater, respectively. This approach works well for the problem of simulating the mixing of waters of different salinities that was the purpose of the present study. Values of density are associated by SWIP with the extreme values of solute fraction and are used in calculations of flows driven by density gradients and in adjusting hydraulic parameter values for changes in fluid characteristics.

The free-surface simulation capability was made part of the 1979 version of the code by INTERA Environmental Consultants, Inc. (1979). The author has modified the code to compute an evapotranspiration rate at all nodes designated as "recharge nodes." This function was coded implicitly to ensure stability (Trescott and others, 1976, p. 8). The author has made a number of additional mathematical and nonmathematical modifications to the code. One nonmathematical modification permits the explicit specification of timevarying boundary conditions on the periphery of the modeled domain. Some mathematical modifications consist of revisions to the standard methods for the computation of vertical advective and dispersive fluxes of solutes (Merritt, 1993). The new methods are described in a later section of this report. A minor modification made for this study was to provide an option to delete solute-transport computations from the top layer of the grid. This option was used to avoid the growth of instabilities in parts of the aquifer above sea level where saltwater intrusion would not occur. These instabilities occurred near the coast where the fractional saturation of cells whose base was sea level was very small, and the apparent cause was cumulative round-off error following several tens of thousands of time steps.

\section{Representation of Dispersive Processes}

Although values computed by a model code (pressures or heads) or parameter values representing aquifer characteristics (hydraulic conductivity and effective porosity of the aquifer material) specified prior to execution of the model code determine an estimate of the average velocity for either freshwater or saltwater in the neighborhood of a point in an aquifer, the actual velocity of individual fluid parcels within that neighborhood can vary appreciably. The localscale hydraulic processes causing this to occur are collectively referred to as mechanical dispersion.

Conceptual explanations of the mechanical dispersion process in carbonate rocks with secondary porosity note that individual fluid particles probably move through solution channels that vary in tortuosity, and fluid velocity can vary across the cross-sectional 
area of each channel. These flow nonuniformities might be accompanied by a degree of turbulent mixing. If this conceptualization is accurate, then, as a consequence, after a period of movement of a saltwater interface, the displacement of either freshwater or saltwater by the other fluid would not be uniform because of the variability of the speed of fluid parcels in the direction of general fluid motion. Therefore, in a spatially averaged sense, there would be a gradual variation of water composition in the vicinity of the interface between freshwater and saltwater in which the composition ranges from that of freshwater to that of saltwater. The region where average water composition is a mixture of the two waters was previously referred to as the transition zone. The mixing of the two waters within the transition zone and consequent upward buoyant flow of mixed saltwater and freshwater over the body of pure saltwater constitute a process of entrainment and partial flushing of the saltwater that, in a coastal environment, has been hypothesized as causing flow at a low rate toward the transition zone within the seawater body (Cooper, 1959).

Descriptions of the Fickian diffusion algorithms often used for a mathematical representation of the mechanical dispersion process are provided by Scheidegger (1961) and Bear (1972), and the concepts have been summarized in a discussion of numerical methods for solute-transport simulation (Merritt, 1993). Generally, characteristic lengths (longitudinal and transverse dispersivities) represent the degree of dispersion that occurs in the direction of flow and perpendicular to the direction of flow.

The breadth (width or degree of attenuation) of the transition zone is implicit in the value of longitudinal dispersivity $\left(\alpha_{l}\right)$. A small longitudinal dispersivity implies a relatively sharp interface (a narrow transition zone where the spatial variation of the water composition occurs abruptly over a small longitudinal interval). A large longitudinal dispersivity implies a broad or diffuse interface (a wide transition zone where the spatial variation of the water composition occurs gradually over a large longitudinal interval). The value of transverse dispersivity $\left(\alpha_{t}\right)$ determines the degree to which moving water tends to spread perpendicularly to the average direction of flow. When the freshwatersaltwater interface moves, the vertical movement of freshwater or seawater is partly advective and partly dispersive. The vertical motion can be considered conceptually to occur both as the development of a transition zone in the direction of flow and as the movement of particles of fluid from the advancing and retreating fluid bodies perpendicular to the average direction of flow caused by local nonuniformities in the orientation of fluid pathways.
That dispersion about the freshwater-saltwater interface occurs in the Biscayne aquifer is evident from a consideration of chloride concentrations in water samples from monitoring wells where water samples have become increasingly saline with time (figs. 12, 16, 19, and 26). In every case, a gradual increase in chloride concentration occurred as the transition zone moved past the monitoring well. Apparently, the short open interval at the bottom of most of the monitoring wells either tapped multiple channels, some containing freshwater and some containing saltwater, or tapped a channel(s) containing a mixture of the two waters.

The dispersive properties of the Biscayne aquifer are not known to have been quantitatively measured in any independent study. The author has used values of $65 \mathrm{ft}$ for dispersivities in radial flow from a well during tests of injection, storage, and recovery in the Upper Floridan aquifer near Hialeah (Merritt, 1996a) and $250 \mathrm{ft}$ for the simulation of a plume of brackish water 5 to $10 \mathrm{mi}$ long in the Biscayne aquifer in central Dade County (Merritt, 1996c). However, dispersion coefficients exhibit various forms of scale dependence (Gelhar and others, 1992), and the assignment of appropriate dispersivity values is problem dependent.

Solutes also diffuse on a molecular scale within ground water. The degree of molecular diffusion of chloride ions from saline water into freshwater is specified parametrically in most mathematical models by a coefficient of molecular diffusivity $\left(D_{m}, \mathrm{~L}^{2} / \mathrm{T}\right)$. In simulating the injection, storage, and recovery of freshwater at Hialeah (Merritt, 1996a), a calibration of freshwater transport away from and toward the well in a thin flow zone overlain and underlain by brackish water was obtained by using a molecular diffusivity value of $0.0002 \mathrm{ft}^{2} / \mathrm{d}$. The match of observed and simulated salinities was not achieved using values of $0.001 \mathrm{ft}^{2} / \mathrm{d}$ or zero.

Molecular diffusion can be significant when fluid velocity is zero. Molecular diffusion might contribute appreciably to the process described as hydrodynamic dispersion if non-native water invading solution channels receives ions from or loses ions to the surrounding rock matrix containing water of the native-water density (whether fresh or salty). Otherwise, when vertical ionic diffusion between zones of different predominant water quality does not occur to a significant degree, the effect of molecular diffusion is probably negligible compared to that described as mechanical dispersion in large-scale solute movement in carbonate rocks. When the effects of molecular diffusion and mechanical dispersion are grouped conceptually or in mathematical formulations for computational 
purposes, the group of processes is referred to by the term hydrodynamic dispersion, represented by the tensor quantity $\underset{\sim}{E}$ which appears in equation 5 and is defined by equation 6 .

\section{Numerical Dispersion and Solution Instability}

When the SWIP code user option of backward spatial differencing is selected for the advective terms, an error is introduced into the solution of the solutetransport equation that has the appearance of hydrodynamic dispersion. This error is termed numerical dispersion. According to Bear (1979, p. 262), "Mathematically speaking, numerical dispersion is a truncation error resulting from the fact that in approximating the first derivative, $\partial c / \partial x$, we have neglected the term proportional to the second derivative:

$$
v \frac{\partial c}{\partial x} \cong v \frac{C_{i}-C_{i-1}}{\Delta x}-v \frac{\Delta x}{2} \frac{\partial^{2} C}{\partial x^{2}}
$$

A numerical dispersion coefficient, $v \Delta x / 2$ is thus introduced." The expressions given in the equation are explained as follows, where:

$$
\begin{aligned}
& v \text { is fluid velocity }(\mathrm{L} / \mathrm{T}) \\
& x \quad \text { is the spatial coordinate }(\mathrm{L}) \\
& C \text { is a unitless measure of concentration } \\
& C_{i}, C_{i-1} \quad \begin{array}{l}
\text { are values of } C \text { at adjacent cell centers of the } \\
\text { spatial discretization }
\end{array} \\
& \Delta x \quad \begin{array}{l}
\text { is the spacing of the finite-difference dis- } \\
\text { cretization }(\mathrm{L})
\end{array}
\end{aligned}
$$

When backward-in-time differences are used, a similar truncation error introduces more numerical dispersion in the amount of $v^{2} \Delta t / 2 \theta$, where $\Delta t$ is the time-step length (T), and $\theta$ (unitless) is the porosity (Lantz, 1971).

When central differencing in time or space is the chosen method, the corresponding finite-difference approximation is correct to the second order, and the first-order numerical dispersion terms are eliminated, so that most of the apparent degree of dispersion in the transport solution depends on the dispersivities and is not determined by the local grid-cell size (given sufficiently fine discretization) or by a changing incremental timestep size. Central-differencing approximations were used for most of the solute-transport simulations in this study. In these simulations, the apparent dispersivity in the solution is considered to be true mechanical dispersion lacking any appreciable component of numerical dispersion.

The formulation of the dispersion terms in the SWIP code "works best," in the sense of replicating the conceptual model of dispersion, when a region of changing concentration is finely subdivided into many grid cells in the direction of fluid movement. Alternatively, the representation may work best in regions where the spatial variation of concentration is "gradual" relative to the grid spacing. Similar advice regarding finely discretizing the zone of concentration change is offered by Kipp (1987, p. 116-117).

The dispersion representation does not work as well when concentration changes are abrupt relative to the grid spacing in the direction of flow. In this case, specification of a large longitudinal dispersivity can cause the simulated concentration variation to be distributed over a larger spatial volume than is realistic. Specification of a small longitudinal dispersivity may allow spatial oscillations to grow in the absence of the smoothing effect of dispersion (the "undershoot" and "overshoot" described by INTERCOMP Resource Development and Engineering, Inc., 1976). Spatial oscillations, when using central differences, represent an incompatibility between the choice of longitudinal dispersivity and the grid dimensions. At times, the range of values that can be assigned to longitudinal dispersivity may be restricted by a coarser than desired grid spacing mandated by the need for computational efficiency.

Numerical oscillations at a grid node in sequential timesteps indicate an incompatibility between the speed of solute movement and the time-increment sequence used to simulate it. Such oscillations can permanently distort the simulated concentration field. At times, numerical oscillations in successive timesteps can increase in magnitude to the point that the number of digits available in the exponents of computer words containing the values of solution variables is exceeded, leading to a premature termination of the simulation run.

Numerical criteria for avoiding oscillatory behavior were developed by Price and others (1966) and are cited in the SWIP code documentation (INTERCOMP Resource Development and Engineering, Inc., 1976) and in the HST3D code documentation (Kipp, 1987, p. 114). In this study, the maximum permissible timestep was determined by a process of trial and error by repeatedly running the model for a long simulation time with different time increment limits and observing when significant oscillations in subsequent 
timesteps did not occur. The maximum permissible timestep was observed to be related to the speed of interface movement, which is related in turn to the hydraulic conductivity value specified for the aquifer. In one set of simulations of a layered model with hydraulic conductivity values ranging between 1 and $50 \mathrm{ft} / \mathrm{d}$, the maximum allowable timestep was 1.0 day. The simulation time period required for convergence to steady state was 400 years, which helps to explain why transient solutions with the diffuse-interface simulation approach are so demanding of computational resources. In another set of simulations in which a uniform hydraulic conductivity of $10,000 \mathrm{ft} / \mathrm{d}$ was specified, the maximum allowable timestep was only 0.1 day, owing to the more rapid movement of the interface to its equilibrium position. However, convergence was achieved within a 30 - to 40 -year simulation time period.

The ability to choose grid-cell dimensions and dispersivities to realistically portray a zone of concentration change depends upon having some physical conceptual model of the transition zone based on field data, and upon having adequate computational resources. In this study, the choice of grid-cell spacing and the longitudinal dispersivity, described in subsequent pages, is partly based on the physical dimension of the freshwater-saltwater transition zone as described by time series of water samples from many wells at a few isolated locations, such as the area east of the Hallandale Well Field.

\section{Dispersion and Advective Weighting Algorithms}

In solute-transport models such as SWIP, the transverse dispersivity value represents the degree of mechanical dispersion in a plane perpendicular to the direction of flow, but does not distinguish between transverse dispersion within the plane of flow (the bedding plane) or perpendicular to it (dispersion in the crossbed or vertical direction). However, macroscopic hydraulic properties may be different or have varying degrees of spatial continuity along the different directional components of fluid flow paths. In rocks with solution porosity, transverse dispersion might be partly related to the tortuous orientation of solution features, but the extent to which this occurs might not be the same in the vertical direction as within the plane of flow.

When vertically adjacent layers are of different hydraulic conductivity, situations occur in which the more permeable layer is partially flushed by water of different quality than that of the other layer, perhaps as a result of flow from a recharge area, flow from an injection well that has not fli sh:d the less-permeable zone to a similar extent, or flow from $\varepsilon_{\text {i supply well }}$ that draws saline water into a pumped zone. Usually, the flow direction in the more permeable layer is nearly parallel to the interface between layers. Because of common data limitations and the need to spatially discretize hydraulic properties for application of finite differences, the vertical transition of hydraulic properties and water quality is usually represented as a step function between adjacent layers of grid cells. In this case, use of central-difference approximations for vertical advective flux of solute across the interface between layers would imply that water flowing across the interface would have a solute composition that is a mixture of the two waters. However, a more realistic conceptual model of flux across the interface is of hydraulically driven seepage of water having the quality of that in the originating layer, so that an upstream (backward) advective weighting scheme would seem to be more appropriate regardless of the type of spatial weighting used in the remainder of the modeled domain.

When vertically adjacent layers contain waters of different quality, the vertical component of dispersion implied by the dispersion algorithm may be inappropriate because the transition of water quality is not simulated as occurring gradationally across the thicknesses of several grid cells, as recommended by Kipp (1987), and is nearly perpendicular to the direction of flow. Providing a finer vertical discretization may not always be computationally efficient, and there might not be any data describing vertically gradational hydraulic and water-quality variations in adequate detail. Besides, a fine vertical discretization merely serves to portray the transport process in greater detail. The sharp break in solute concentration that can occur between layers of different hydraulic conductivity will still cause a high degree of vertical dispersion to be simulated using standard methods that represent hydrodynamic dispersion. The use of a small transverse dispersivity value might not be helpful because vertical dispersion is also a function of longitudinal dispersivity, and a small transverse dispersivity value might not be appropriate in the horizontal plane.

Another problem occurs when there is a large difference in scale between the horizontal and vertical dimensions of grid cells. When transport processes occur over distances of several miles in aquifers a few tens of feet thick, computational economy may mandate that the ratio of average horizontal and vertical grid dimensions be two or more orders of magnitude. A large value for longitudinal dispersivity may be required to match the coarse horizontal discretization. 
However, particularly if a smaller but still appreciable degree of vertical flow occurs, this may cause substantial vertical dispersion to be simulated (a combination of the vertical velocity component and the large longitudinal dispersivity) that obscures actual vertical solute concentration variations. This can occur even when a small transverse dispersivity value is specified, and the use of a small transverse dispersivity value might not be appropriate in the horizontal plane.

These problems are discussed in greater detail by Merritt (1993). To provide the means for more physically realistic simulation of transport processes in the situations described, modified algorithms for representing vertical advective and dispersive fluxes of solute were encoded as options in the SWIP simulator (Merritt, 1993). The modified algorithms implement the concepts described in the following statements:

- Mechanical dispersion in the vertical direction is identically zero between adjacent layers of different permeability $\left[\left(K_{x}(k) \neq K_{x}(k-1)\right]\right.$, where $K_{x}$ is the hydraulic conductivity in the $\mathrm{x}$-coordinate direction. Molecular diffusion between layers occurs as before. Between layers of similar permeability $\left[K_{x}(k)=K_{x}(k-1)\right]$, mechanical dispersion in the vertical direction is scaled by a userspecified factor $S(0 \leq S)$ (Merritt, 1993). The scaling factor is a multiplicative factor applied to the vertical mechanical dispersion simulated by the standard method. Molecular diffusion is not scaled.

- Vertical advective flux of solute receives upstream weighting (backward differencing) across the boundary between layers of different permeability $\left[K_{x}(k) \neq K_{x}(k-1)\right]$, regardless of which weighting is used in the rest of the spatial domain of the model.

The modified algorithms implement the conceptual view that solute flux across the boundaries between layers of different permeability occurs as molecular diffusion or as hydraulically driven seepage where the water flux has the solute concentration of the source layer. The scaling factor is a user-specified parameter for problems where bedding effects or the discretization may cause incompatibility in the description of horizontal and vertical dispersive processes within a homogeneous layer.

The simulation of saltwater intrusion in southeastern Broward County involves the transport of water of variable density over distances of miles in an aquifer that is a few tens or hundreds of feet thick, and the transport process has an appreciable vertical component. Whether modified dispersion and advective weighting algorithms provide a more accurate representation of the physical processes that occur than do the standard algorithms can best be determined by using and comparing both methods in attempts to replicate field data. Unfortunately, the data available for this study were insufficient to accomplish this purpose (except to suggest that the interface is relatively sharp). However, sensitivity analyses were performed in a hypothetical cross-sectional model grid and were helpful in showing the range of variation of simulation results that is theoretically possible when the representational methods are varied.

\section{Grid Design and Parametric Coefficient Value Assignments}

The grid was designed and values of parametric coefficients were selected to facilitate comparison of the application of the SWIP and SHARP codes to simulate the predevelopment saltwater interface. A crosssectional grid design was used for the SWIP code application. This approach was consistent with the SHARP application because the SHARP predevelopment simulation was designed to depict uniform easterly flow. The approach also continues the adherence to the conceptual model of eastward flow to offshore discharge areas. The region of space contained within the SWIP grid ranged vertically from land surface to the base of the Biscayne aquifer, the same thickness represented areally in the SHARP application.

The vertical discretization was used to depict spatial variations in the vertical distribution of saltwater and freshwater (the position of the interface and toe). The SWIP simulations were run in transient mode until virtual convergence to a fixed position was achieved for all concentration lines within the transition zone. Unlike methods used in applying the SHARP code, no convenient strategy was found to accelerate convergence of the SWIP solution to steady state. Timestep restrictions mandated by the relation between the rate of solute movement and solution stability had to be observed. The use of lower effective porosity values only increased the speed of solute movement, decreasing the maximum allowable timestep. SWIP analyses, therefore, required significantly greater run times and use of computational resources than did the SHARP analyses.

The grid dimensions in the cross section were variable both horizontally and vertically (fig. 31). The uppermost layer was of variable thickness (3 to $12 \mathrm{ft}$ ), and its surface represented the land-surface elevation above sea level. The bottom of the layer was at sea level. Layers 2 to 5 of the cross-sectional slice were horizontally uniform in thickness, having a combined total thickness of $48 \mathrm{ft}$. Layers 6 to 11 of the grid represented the principal producing zone of the Biscayne aquifer and were of equal thickness vertically within each column. The vertically uniform thicknesses increased from $12 \mathrm{ft}$ each at the west end of the cross 


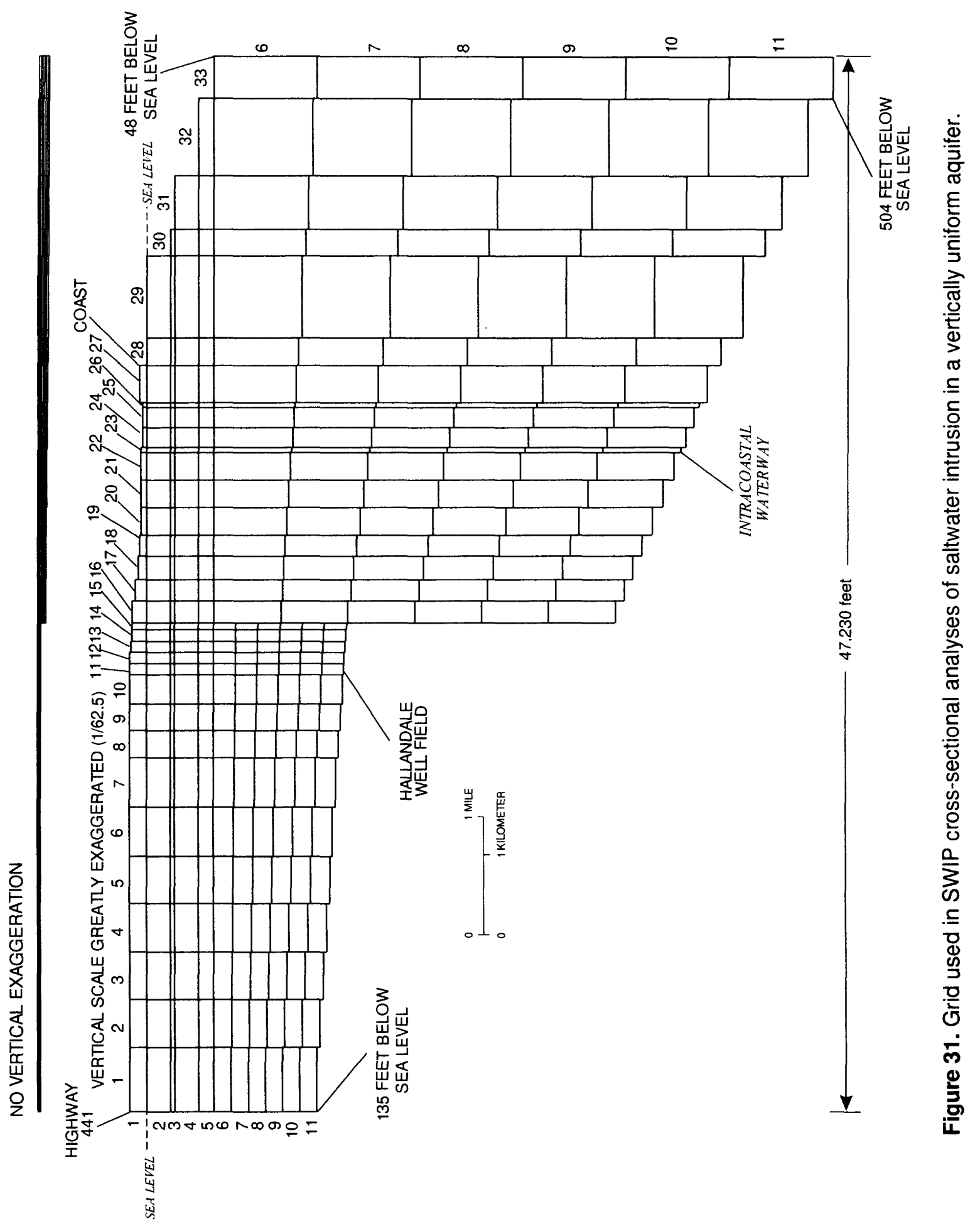


section (Highway 441 ) to $59 \mathrm{ft}$ each at column 27 of the cross section (the Atlantic coast). The thickness of the six layers increased further beyond the coast to an undersea outcrop, as in the SHARP model grid. It should be noted that the horizontal internodal fluxes formulated by the SWIP code are between nodes in layers with the same vertical index. Because there is a large vertical displacement between grid cells of each layer between columns 15 and 16 , it was likely that discontinuities in simulated head and saltwater concentrations would occur there.

The sea bottom was represented by making selected upper layers inactive offshore and by specifying a vertical boundary pressure condition that corresponded to the local average depth of seawater. The bottom configuration was the same as used for the SHARP runs. As for the SHARP application, horizontal hydraulic conductivity was a uniform $10,000 \mathrm{ft} / \mathrm{d}$. Vertical hydraulic conductivity was $1,000 \mathrm{ft} / \mathrm{d}$. Density assignments were $62.26 \mathrm{lb} / \mathrm{ft}^{3}$ for freshwater $(C=0)$ and $64.0 \mathrm{lb} / \mathrm{ft}^{3}$ for saltwater $(C=1)$. Effective porosity was a uniform 20 percent. The viscosities of freshwater and saltwater were considered the same $(0.98 \mathrm{cp})$, and isothermal conditions at $70^{\circ} \mathrm{F}$ were assumed to prevail. Recharge was specified to be $61.76 \mathrm{in} / \mathrm{yr}$ $(0.0141 \mathrm{ft} / \mathrm{d})$, the $79-\mathrm{yr}$ annual average for Fort Lauderdale; the annual average maximum evapotranspiration rate was specified to be $0.0136 \mathrm{ft} / \mathrm{d}$ based on results from the previously cited Dade County study (Merritt, 1996b). Evapotranspiration was assumed to occur at a maximum rate within a 3 -ft shallow root zone, then to decline linearly to an extinction depth of $20 \mathrm{ft}$ below land surface. Aquifer material and water compressibilities were $1.5 \times 10^{-5}$ and $3.0 \times 10^{-6}(\mathrm{lb} /$ $\left.\mathrm{in}^{2}\right)^{-1}$ (pound per square inch) ${ }^{-1}$, respectively.

As in the SHARP predevelopment model application, a freshwater hydrostatic pressure boundary was used on the landward end of the cross section representing a head of $5 \mathrm{ft}$ above sea level. The pressure boundary conditions on the seaward end of the cross section were specified at the elevation in the columns where the top of the grid decreased in altitude below land surface to represent the ocean floor, deepening toward the edge of the Atlantic Shelf. The boundaries were either an overhead (vertical) specification or a horizontal specification representing the appropriate depth of seawater. Because the grid cells were thousands of feet long but only tens of feet thick, the overhead (vertical) pressure specifications were predominant in controlling simulated pressures near the ocean end of the grid. The average seawater head was assumed to be $0.75 \mathrm{ft}$ above sea level, as is typically measured in tidal gages along the coast of Broward County (table 1).
Longitudinal and transverse dispersivities were 400 and $0 \mathrm{ft}$, respectively in most simulations. In some simulations, the longitudinal dispersivity was reduced to $40 \mathrm{ft}$. Despite the zero value of transverse dispersivity, vertical dispersion was non-zero, owing to nonzero values of longitudinal dispersivity and molecular diffusivity $\left(0.001 \mathrm{ft}^{2} / \mathrm{d}\right)$. The previously cited modified dispersion and weighting algorithms were used, and a scaling coefficient (S) of 0.009 was applied to the computed values of vertical dispersion between layers with the same hydraulic conductivity. This value was the ratio of the average vertical grid spacing to the average horizontal grid spacing. Use of the standard dispersion algorithms in conjunction with the large longitudinal dispersivity values was considered undesirable because the corresponding simulated degree of vertical dispersion was considered unrealistically high, as will be demonstrated in simulations using the standard algorithms.

An initial position for the interface was simulated by a method based upon the Ghyben-Herzberg relation. First, a sharp vertical interface at the coast was specified. Then a series of steady-state pressure solutions was performed. After each solution, grid cells with nodal centers below the Ghyben-Herzberg depth were assigned saltwater densities. Higher cells were assigned freshwater densities. Convergence was usually achieved after less than 10 steady-state solutions.

It was not appropriate to simulate pumping in the SWIP cross-sectional models, and north-south dimensional uniformity was an inherent assumption of the cross-sectional grid design. Therefore, all SWIP crosssectional simulations were attempts to estimate predevelopment conditions. The specified inland boundary head $(5 \mathrm{ft})$ was that estimated for predevelopment conditions in that area.

\section{Simulation of a Vertically Uniform Aquifer}

Convergence to a steady-state position and degree of dispersal of the transition zone (figs. 32 and 33) was achieved by running SWIP for a simulation period of 40 years. There was little change after 10 years. The previously cited SWIP estimates for recharge, maximum potential evapotranspiration, and evapotranspiration extinction depth resulted in the simulation of an average net recharge rate of about 12 in/yr, which changed very little when dispersivity was varied. As was the case with the SHARP code results, the center of the transition zone, assumed to be approximated by the line of 50 -percent saltwater concentration (fig. 32), was above and landward of the Ghyben-Herzberg line derived from the head distribution corresponding to the equilibrium interface 


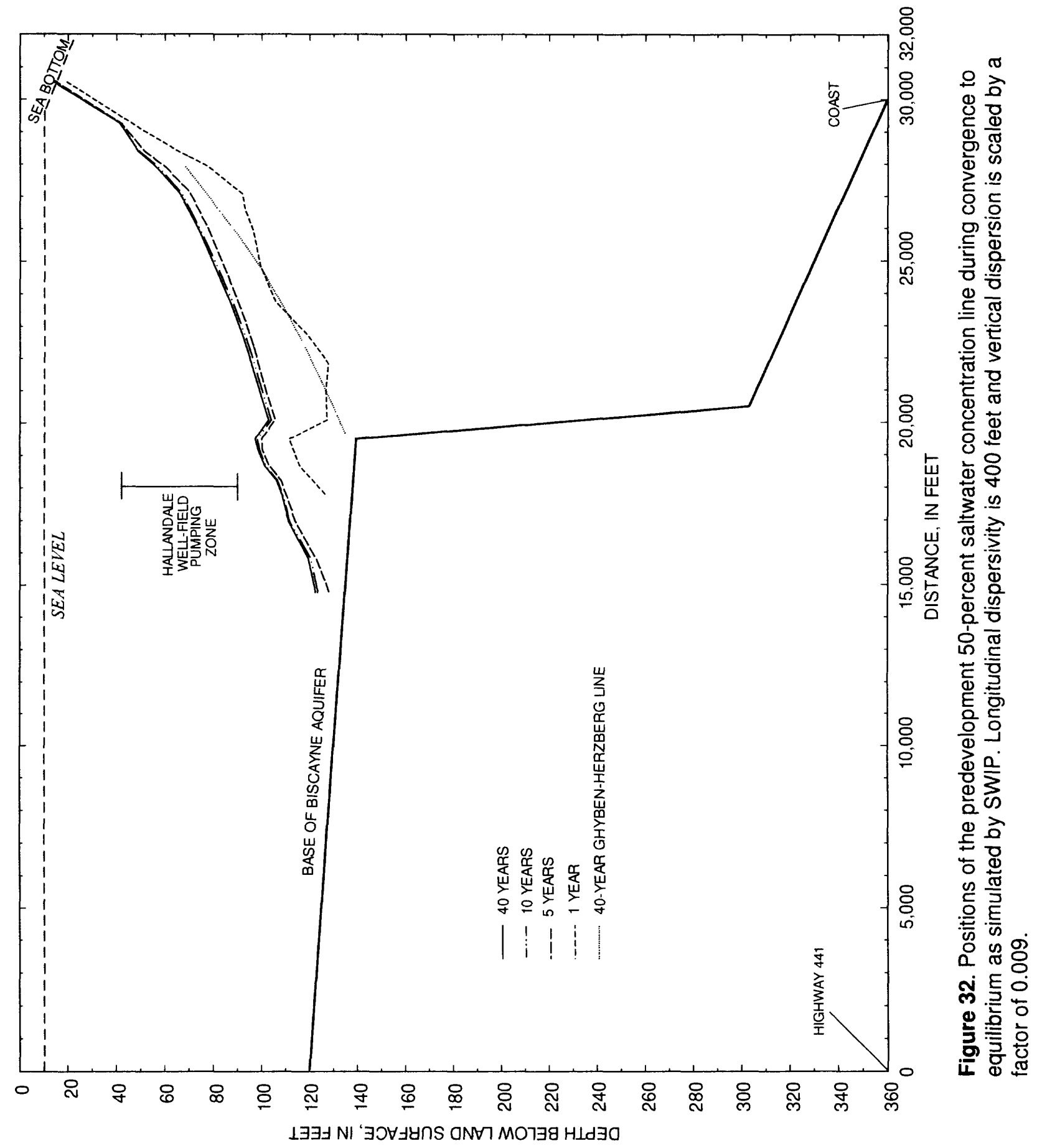




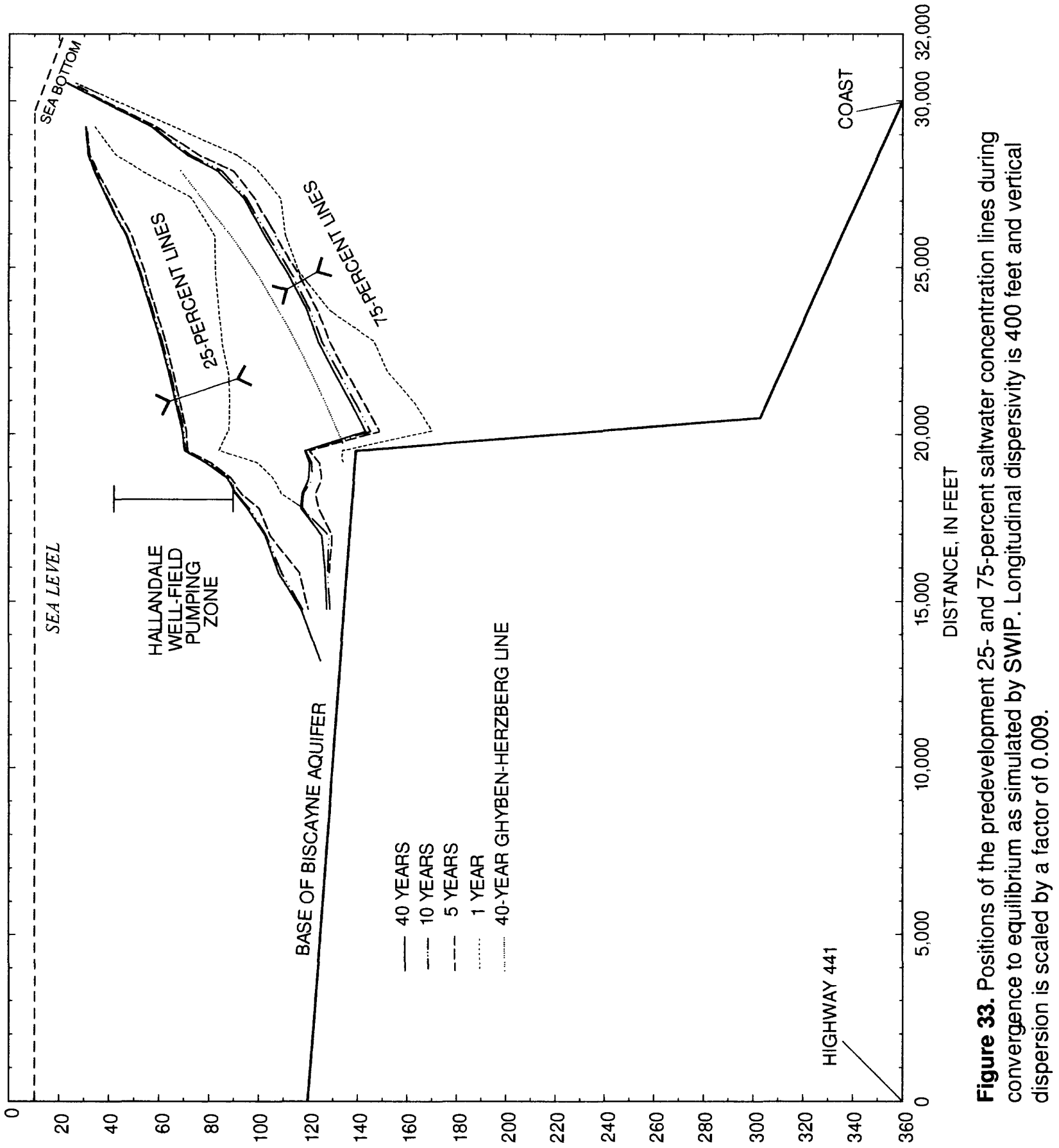

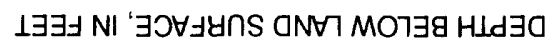


position. The simulated interface altitude is depicted as dropping abruptly at a point just seaward of the location (fig. 31, between grid columns 15 and 16) where the aquifer is represented as abruptly thickening, beyond which the interface altitude rises farther seaward. This is probably a manifestation of the expected discontinuities in simulated concentrations caused by the vertical displacement between adjacent cells in columns 15 and 16 and does not have physical significance. In figures 32 and 33, the boundary between cells 15 and 16 occurs at $19,640 \mathrm{ft}$ from the inland (western) boundary. The interface location in each column of the grid is determined by vertical interpolation between concentration values at grid cell centers. It is noted that the vertical transition in concentration occurs over a thickness that is relatively small compared to the large grid-cell vertical thicknesses in the eastern part of the cross section (columns 16-33). This may affect the accuracy of the vertical interpolation procedure used to determine the position of the 25-, 50-, and 75-percent concentration lines.

The transition zone is simulated as being wider where the aquifer is deeper (figs. 34 and 35). The transition zone is significantly narrower everywhere when a longitudinal dispersivity of $40 \mathrm{ft}$ is specified (fig. 35) than when a value of $400 \mathrm{ft}$ is specified (fig. 34). The 50 -percent saltwater concentration lines corresponding to dispersivity values of 40 and $400 \mathrm{ft}$ are plotted in figure 36 with the sharp interface position simulated by SHARP using aquifer parameters representing predevelopment conditions. The 50-percent saltwater concentration lines are displaced slightly landward of where they should have been simulated because the cumulative effect of slight oscillations in the SWIP solution during nearly $1.5 \times 10^{6}$ time steps caused concentrations greater than 1.0, and corresponding densities somewhat higher than those specified for saltwater, to be simulated in the inshore part of the saltwater region. Simulated densities are only slightly higher than the specified value in the offshore part of the saltwater region. Simulated saltwater densities in the inshore region were 9 to 10 percent higher than $64.0 \mathrm{lb} / \mathrm{ft}^{3}$ when the longitudinal dispersivity was 400 $\mathrm{ft}$ and 25 to 30 percent higher when the longitudinal dispersivity was $40 \mathrm{ft}$. This fact should be considered when comparing the 50-percent saltwater concentration lines with each other and with the SHARP interface line (fig. 36). The 50-percent saltwater concentration line is farther inland when the higher dispersivity is specified, even though a lower inshore saltwater-zone density is computed. The SWIP and SHARP solutions seem to be in general agreement.

An additional simulation was run in which the longitudinal dispersivity $\left(\alpha_{1}\right)$ was $400 \mathrm{ft}$, but a vertical dispersion scaling factor $(S)$ of 1.0 (no scaling) was specified. Because all layers were assigned the same hydraulic conductivity value, this procedure was equivalent to using the standard algorithm for computing vertical dispersion. The specified transverse dispersivity was zero. The result (fig. 37 ) was a very different interface than when $S=0.009$. The transition zone was simulated as being more broadly dispersed and concentrations were more uniform vertically. (It should be noted the vertical scale of fig. 37 is greatly exaggerated, as shown in fig. 31 , so that the simulated interface is still nearly horizontal at true scale.) The simulated transition zone was also shifted seaward of the well field, although the 25-percent saltwater concentration line was simulated to be only about $500 \mathrm{ft}$ east of the well field. When the longitudinal dispersivity was reduced to $40 \mathrm{ft}$, the simulated transition zone (fig. 38) was narrower, and lines of equal concentration were shallower and extended farther inland. The depicted 25-, 50-, and 75-percent saltwater concentration lines were more similar to those simulated when $S$ $=0.009$, but the transition zone was somewhat broader. Densities computed for the inshore saltwater zone were only 3 to 6 percent higher than $64.0 \mathrm{lb} / \mathrm{ft}^{3}$ in both of these runs.

When the transverse dispersivity $\left(\alpha_{t}\right)$ was set equal to $0.1 \mathrm{ft}$ in the latter two scenarios and the scaling factor of $S=1.0$ was retained, simulation results were virtually unchanged from those described above. Simulations with higher values of transverse dispersivity will be described later in the report. The appreciable differences in the structure of the transition zone simulated in the four cases (figs. 34, 35, 37, and 38 ) are related to differences in the specified values of longitudinal dispersivity $\left(\alpha_{l}\right)$ and the vertical dispersion scaling factor $(S)$. Longitudinal dispersion is the primary contributor to dispersion in the vertical direction because a finite nonzero vertical component of the pore velocity is simulated, and a relatively large ( 40 or $400 \mathrm{ft}$ ) longitudinal dispersivity is specified (Merritt, 1993). The large degree of vertical dispersion that results is also a linear function of the scaling factor (S). Longitudinal dispersivity and the scaling factor are, therefore, identified as simulation parameters controlling the degree of influence of vertical dispersion that acts as a primary control on the structure of the simulated transition zone.

Another result of significance in these analyses is that the simulated equilibrium interfaces do not differ substantially from the position predicted by the Ghyben-Herzberg relation. In the four cases (figs. 34, 35, 37 , and 38 ), the simulated head at the Hallandale Well Field ranged from 3.8 to $4.4 \mathrm{ft}$ when equilibrium had been reached. However, the actual position of the interface, as determined from well water samples (figs. 


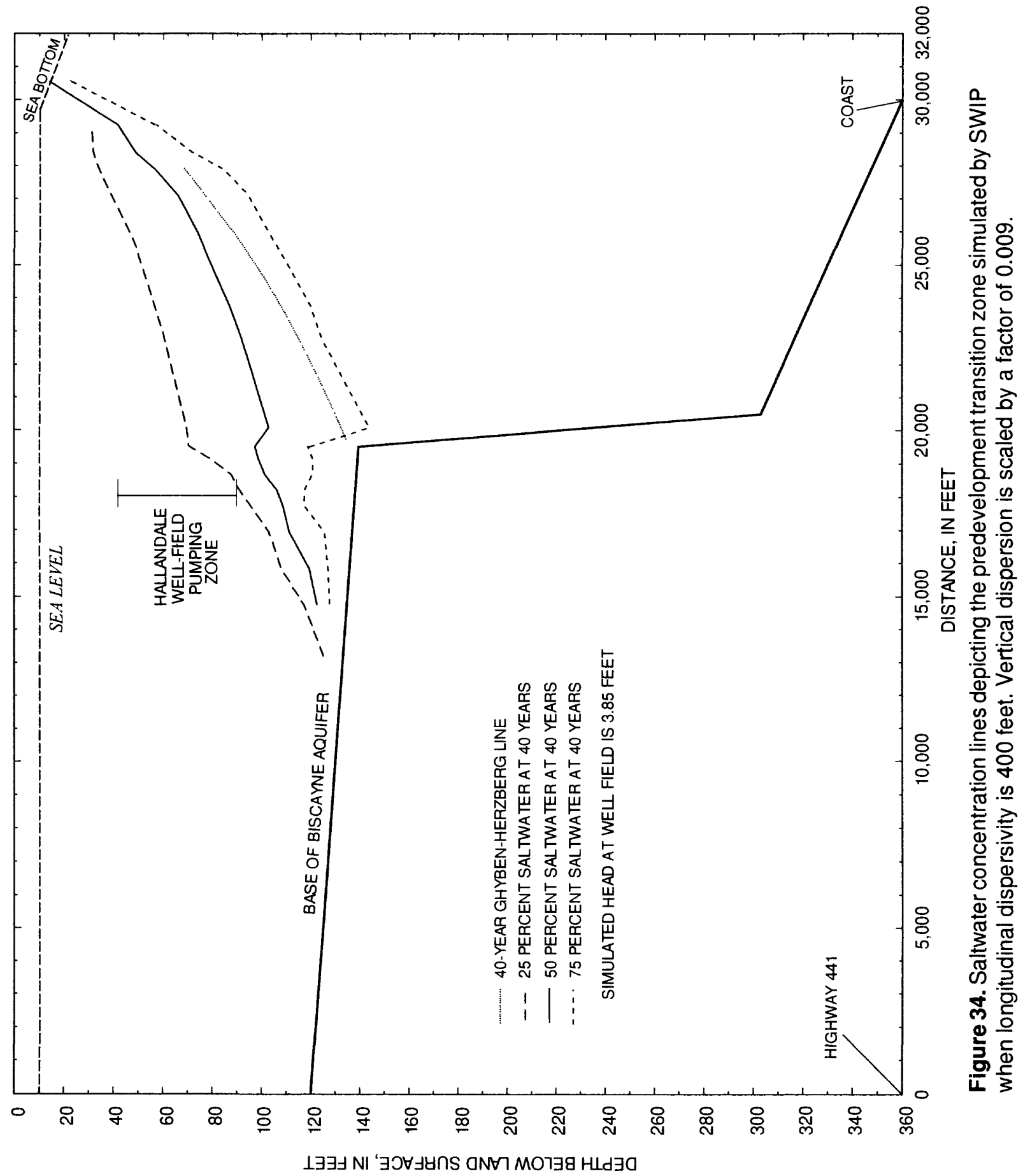




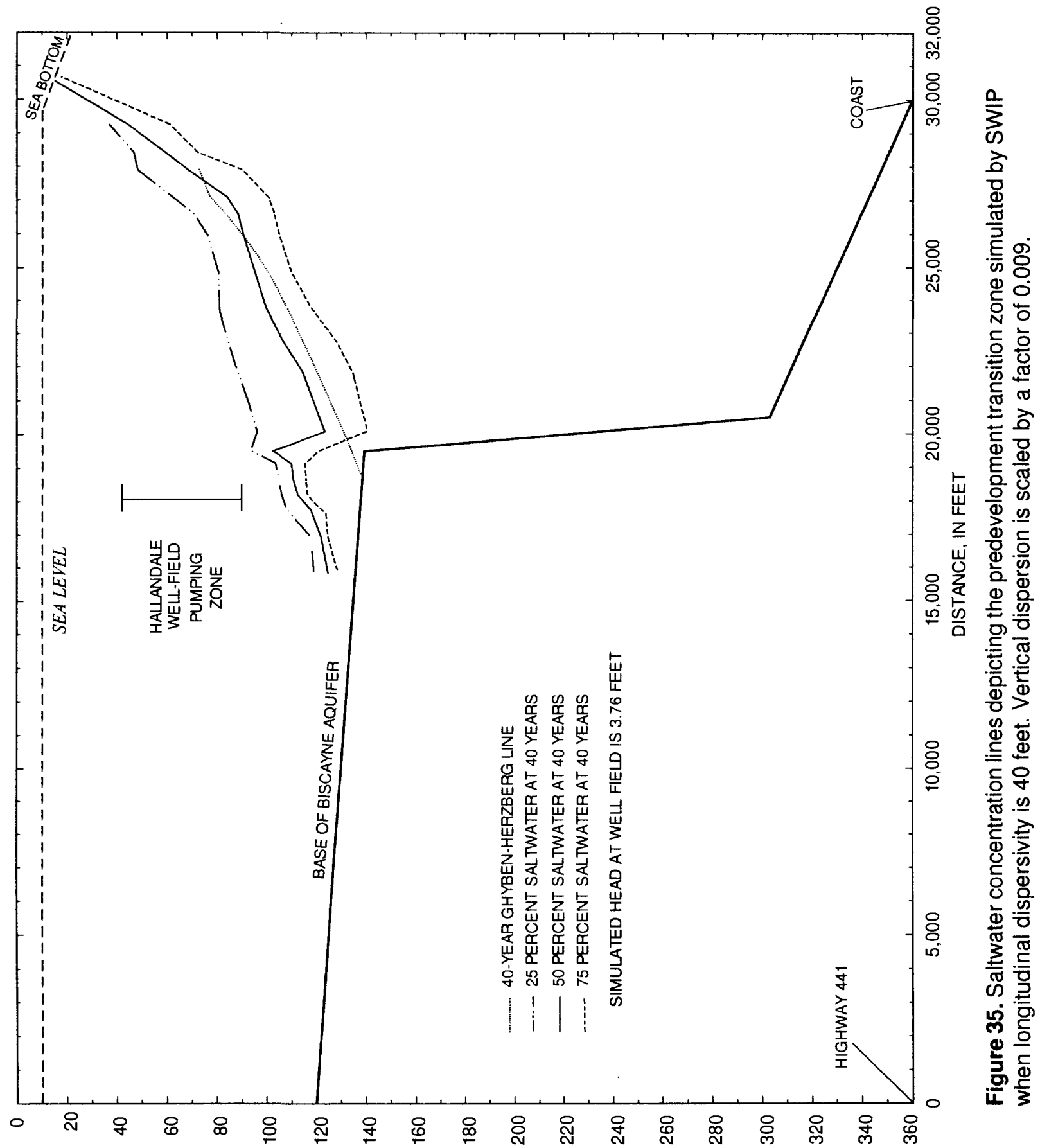

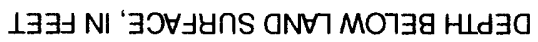




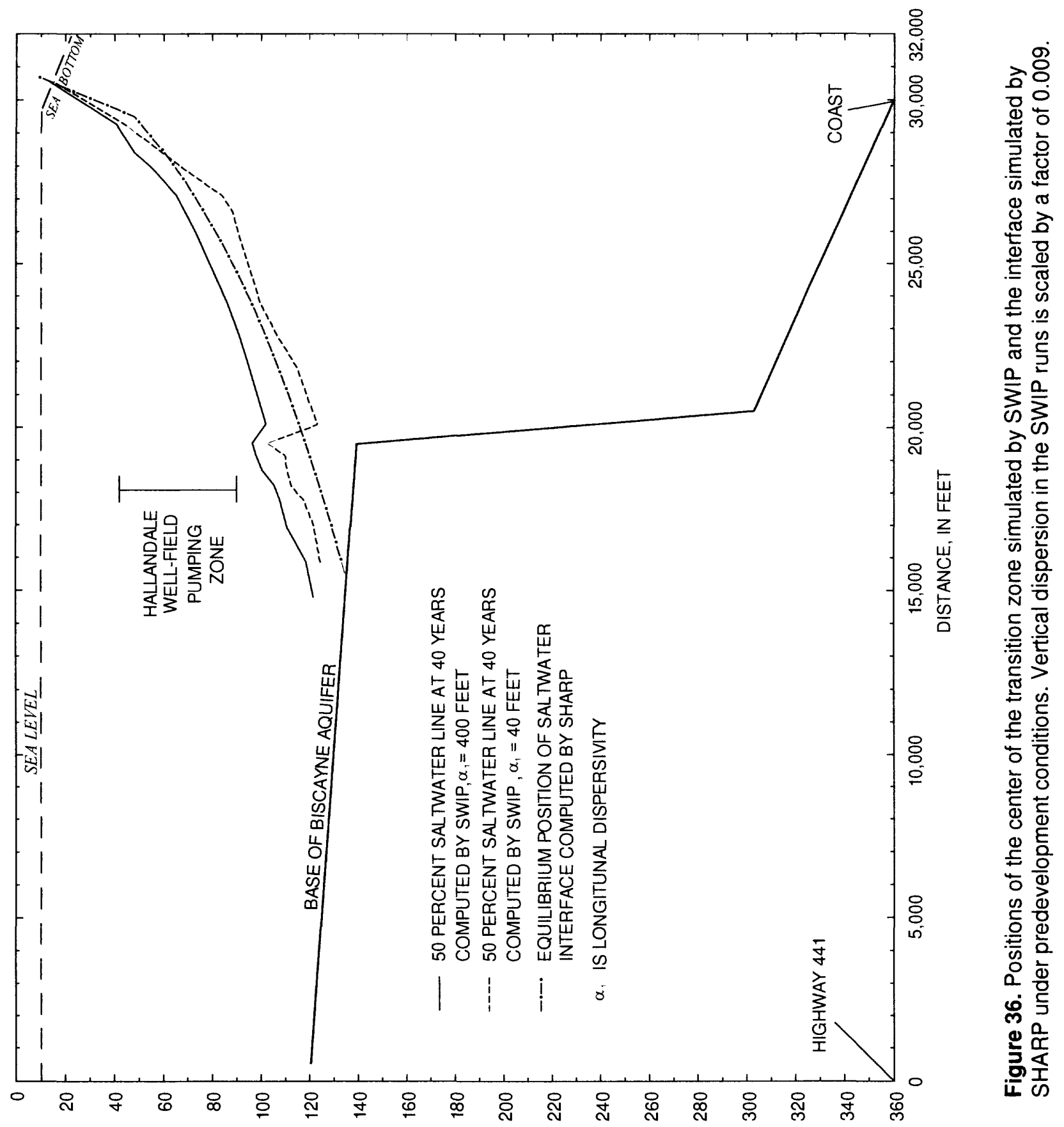

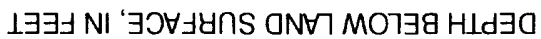




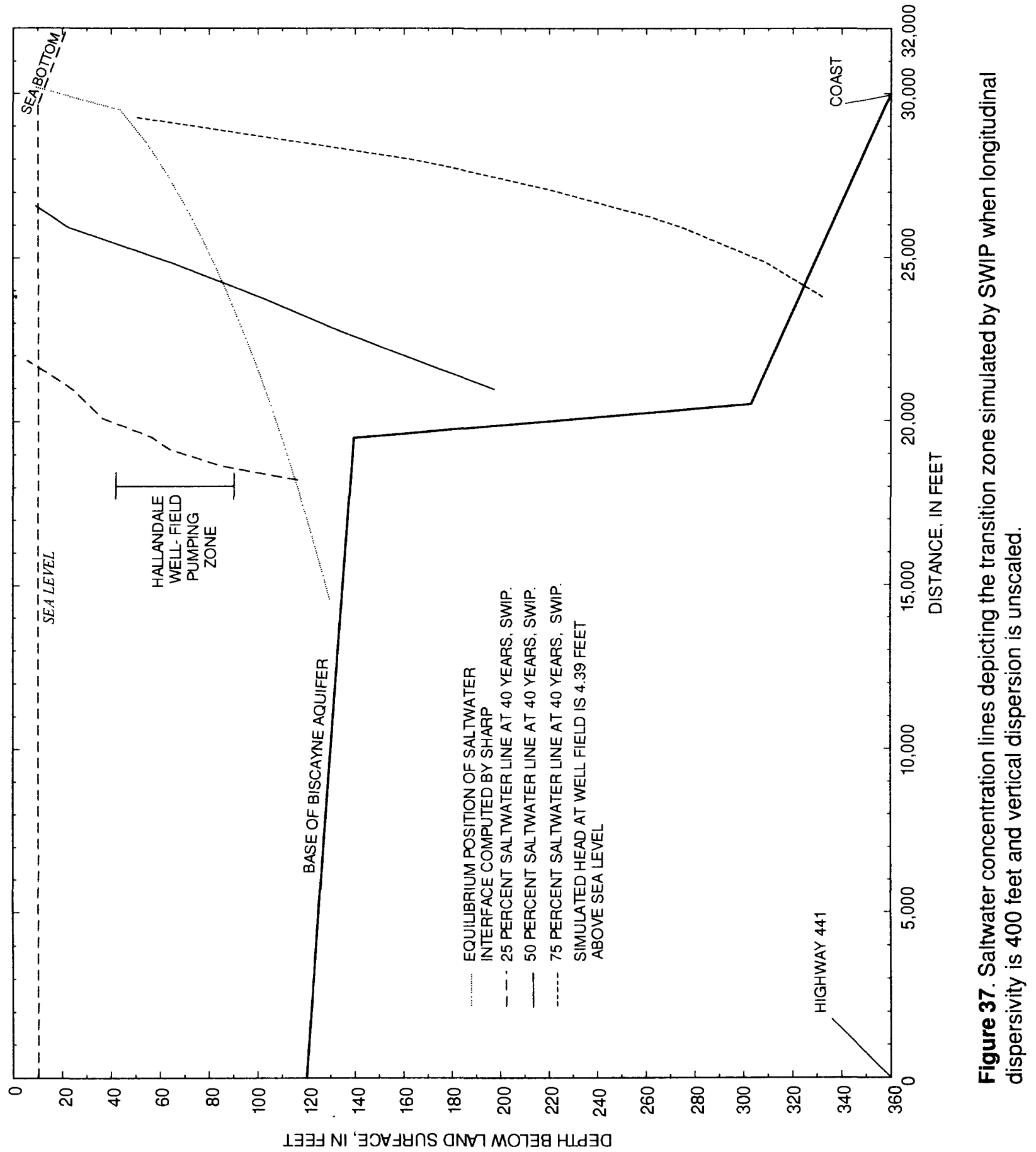




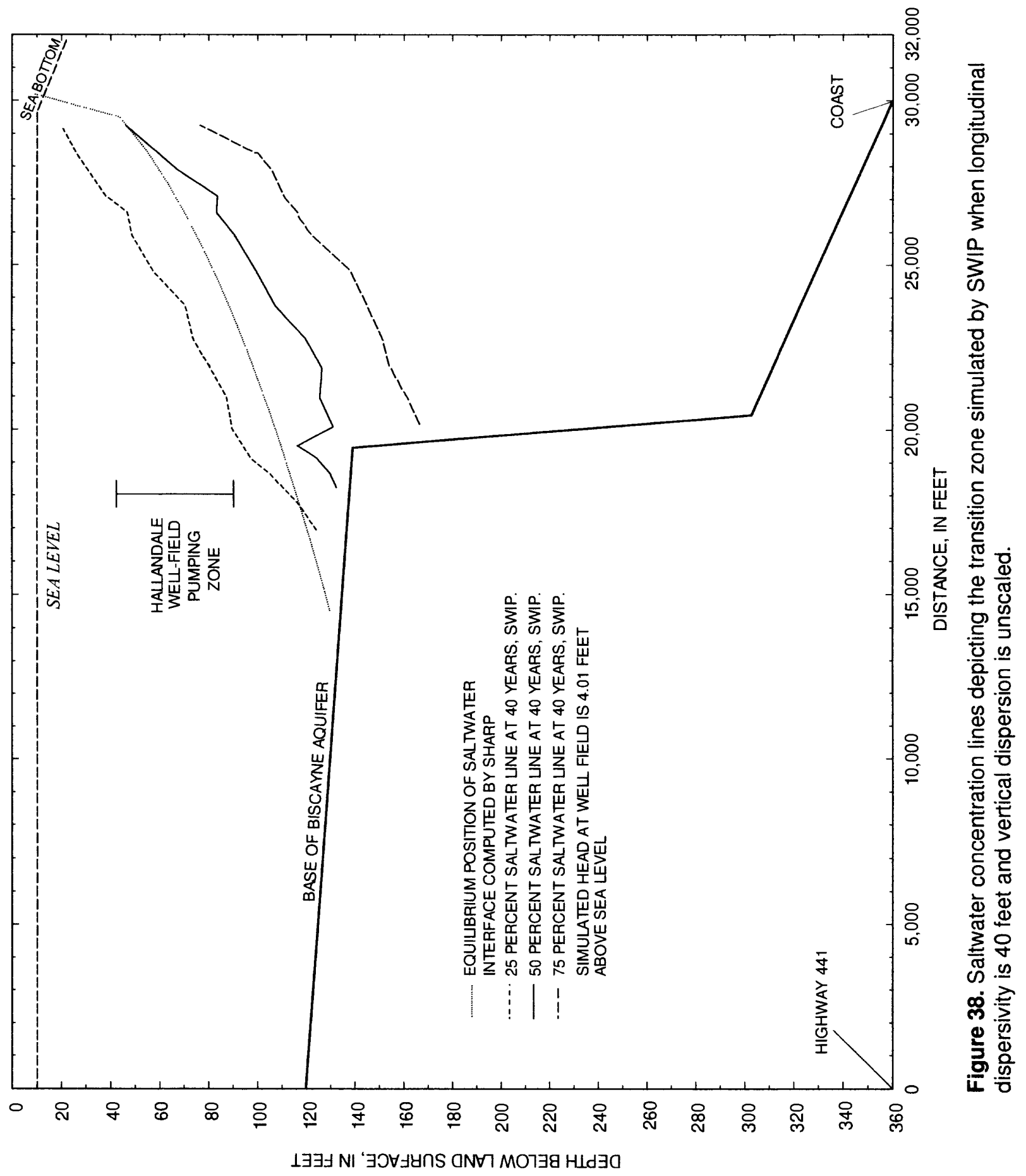


12,15 , and 17), does differ appreciably from that predicted by the Ghyben-Herzberg relation. As previously noted, the head measured at well G-1472, $0.5 \mathrm{mi}$ east of the well field, from 1970 to 1994 has averaged between 1.6 and $1.7 \mathrm{ft}$ and is not considered to be appreciably affected by pumping of the well field. As also previously noted, well G-2328 was drilled to 300 $\mathrm{ft}$ in the center of the well field in 1981 without reaching the saltwater interface. For the interface to be located $300 \mathrm{ft}$ below land surface, the Ghyben-

Herzberg relation would require a local head of nearly $7.5 \mathrm{ft}$. The measured heads might be consistent with an inland boundary condition of $2.5 \mathrm{ft}$, representative of the present-day water-table altitude, instead of $5 \mathrm{ft}$, used to represent the predevelopment water table in these simulations. However, a shallower depth to the interface would also be anticipated. The actual interface position is actually deeper and farther seaward of the positions simulated for predevelopment conditions, which are, therefore, inconsistent with the available data. This dilemma receives further discussion in subsequent sections.

A similar situation exists in the northern part of the study area. When well G-2612 (fig. 17) was drilled in 1990 , a water sample acquired at $273 \mathrm{ft}$ below land surface detected a chloride concentration of only 480 $\mathrm{mg} / \mathrm{L}$. If the interface were at $280 \mathrm{ft}$, the GhybenHerzberg relation would predict an equilibrium head value of nearly $7.0 \mathrm{ft}$. The head recorded at G-1224, $1.2 \mathrm{mi}$ to the north (fig. 7), has averaged 1.6 to $2.0 \mathrm{ft}$ since 1963 (table 1).

The failure of the SWIP and SHARP models to yield results consistent with field data casts doubt upon either the validity of the conceptual model or the representation of the conceptual model for simulation purposes. A new conceptual model is needed in which the position of the interface at equilibrium differs substantially from that predicted by the Ghyben-Herzberg relation, or which implies the persistence for many decades of a nonequilibrium state in which the head/ interface relation differs from that predicted by the Ghyben-Herzberg relation.

In this section, the dispersed interface simulated by SWIP has been shown to converge to an equilibrium position in which all lines of equal chloride concentration within the transition zone remain steady. The SWIP and SHARP solutions are in general agreement when a large longitudinal dispersivity is specified and when the modified dispersion algorithm is used to reduce the degree of vertical dispersion. When the standard dispersion algorithm is used in SWIP in conjunction with a large longitudinal dispersivity specification, a more vertical and highly dispersed transition zone is simulated that differs considerably from the SHARP simulation. SWIP simulations were also shown to generally agree with the GhybenHerzberg relation between head and interface depth. Because the interface position indicated by the field data is seaward, not landward, of the simulated predevelopment interface positions, the simulated positions are inconsistent with the field data.

The 40-year simulations using the standard dispersion algorithm (no scaling of vertical dispersion) required that the computational time step be no greater than 0.10 day. Run (clock) times on the Data General Aviion $300 \mathrm{C}$ for the slightly more than 146,100 time steps were between 24 and 25 hours. When vertical dispersion was scaled by a factor of 0.009 (modified algorithm), the computational time step was not allowed to exceed 0.05 day, and run times for slightly more than 292,200 time steps were between 48 and 54 hours.

\section{Effects of Areally Distributed Permeability}

The capability of the SWIP code to simulate layers of different permeability was used in tests with the cross-sectional model to more realistically represent aquifer characteristics in the study area than was possible using a uniform hydraulic conductivity specification. Simulations with a redesigned grid were used to develop an understanding of how spatial variations in aquifer permeability would affect the simulation of the predevelopment position of the saltwater interface.

As a first step, the layering of the Biscayne aquifer section (layers 6-11) in the previous grid (fig. 31) was made uniform in thickness, and the total number of layers was increased from 11 to 20 (fig. 39). This procedure permitted geologic strata underlying the Biscayne aquifer to be included in the model domain. Layers 1 to 5 were from 10 to $13 \mathrm{ft}$ each in thickness. Layers 6 to 15 were each 15 -ft thick, and layers 16 to 20 were each $40-\mathrm{ft}$ thick. The locally varying thickness of the Biscayne aquifer was represented by varying the number of grid cells in vertical columns to which was assigned the estimated hydraulic conductivity of the Biscayne aquifer $(10,000 \mathrm{ft} / \mathrm{d})$. Cells in the columns directly beneath the Biscayne aquifer were assigned a lower hydraulic conductivity $(100 \mathrm{ft} / \mathrm{d})$ that generally represented the lower permeability of a semiconfining zone (clastics of the Tamiami Formation). The deepest cells in the inland part of the crosssectional grid (columns 1-16) were assigned an even lower hydraulic conductivity value $(0.05 \mathrm{ft} / \mathrm{d})$ to represent the confining character of clay of the Hawthorn Formation. 


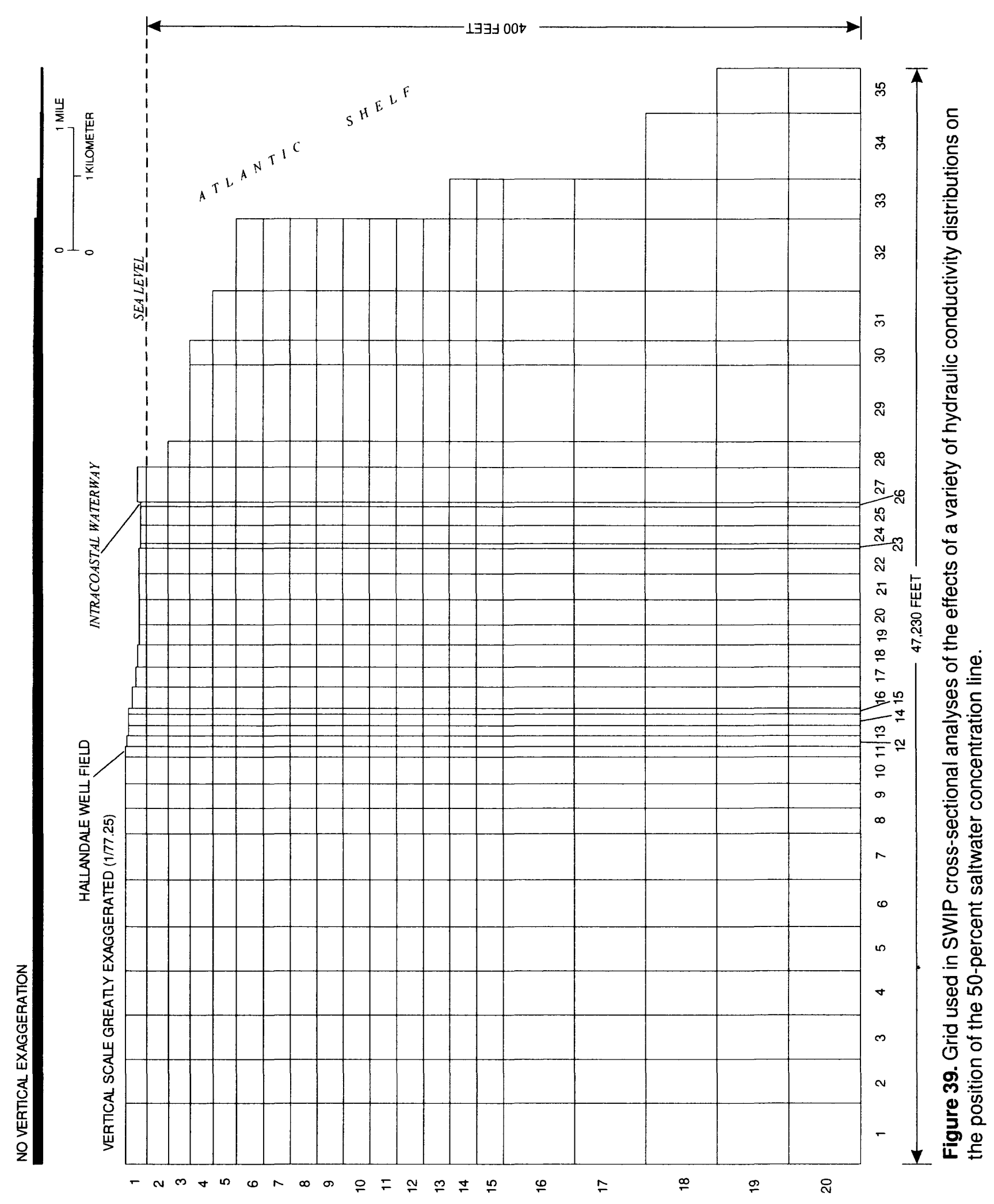


The boundaries of the various zones of different hydraulic conductivity are generally indicated in figure 40 and in later illustrations. The relative positions of the Tamiami and Hawthorn strata in the upper inland part of the cross-sectional grid are shown as the semiconfining zone and the confining zone in figure 40 , but the upper parts of these strata are included in the Biscayne aquifer thickness where it deepens east of a point 2,000 ft from the western end of the cross section. In the analyses, the longitudinal dispersivity $\left(\alpha_{1}\right)$ was $400 \mathrm{ft}$, transverse dispersivity $\left(\alpha_{t}\right)$ was $0.1 \mathrm{ft}$, and the scaling factor for vertical dispersion $(S)$ was 0.015 , the ratio of the average vertical and horizontal grid dimensions. These parameters are similar to those of the 11-layer simulation, the results of which are illustrated in figure 34 . The region shown in figure 40 and later figures includes rows 1 to 19 and columns 1 to 28 and part of column 29 of the grid illustrated in figure 39.

In the first analysis (case 0 ), all subsurface materials lying between land surface and the semiconfining zone or sea bottom were considered to be part of the Biscayne aquifer and were assigned a hydraulic conductivity of $10,000 \mathrm{ft} / \mathrm{d}$. The only significant difference with the previous 11-layer variable thickness model was that the semiconfining and confining zones were represented explicitly in the 20-layer simulations as layers of lower permeability rather than being treated as an impermeable lower boundary of the Biscayne aquifer. The transition zone is simulated as being slightly below and seaward of the position simulated by the 11-layer model (fig. 40). The difference in the positions of the 50-percent saltwater concentration line is partly the result of using a larger scaling factor for vertical dispersion $(0.015)$ in the 20-layer model than in the 11-layer model (0.009). The difference in position is also attributable to the fact that inshore saltwater-zone densities 9 to 10 percent greater than that specified for saltwater were simulated by the 11-layer simulation (figs. 34 and 40), as previously noted. The 20 -layer model run (case 0 ) simulated inshore saltwater-zone densities only 1 to 2 percent greater than that specified for saltwater.

Because of the high hydraulic conductivity value assigned to the upper part of the cross-sectional grid, the maximum allowable timestep was constrained to be 0.10 day to prevent temporal oscillations. Case 0 was run for a simulation time of 133 years, which required a run time of about 153 hours on the Data General Aviion 300C. The 50-percent saltwater concentration line in the Biscayne aquifer reached equilibrium quickly compared to the 50 -percent saltwater concentration line in the semiconfining zone, which was still converging at 133 years. However, the final interface position in the semiconfining zone probably would differ from that shown only by about 500 $\mathrm{ft}$ horizontally (an approximation based on the decreasing distances that the 50-percent saltwater concentration line moved in the last years of simulation time).

In the remaining analyses, the upper five layers $(60 \mathrm{ft})$ of the grid were assigned a lower hydraulic conductivity to represent the effect of the leaky bed of sand and sandstone that occurs throughout the study area and through which rainfall recharge percolates downward to the aquifer. No field data are known to exist that would provide a basis for the assignment of this hydraulic conductivity value. A value of $100 \mathrm{ft} / \mathrm{d}$ was used initially, but resulted in a simulated watertable altitude higher than land surface, so a value of $250 \mathrm{ft} / \mathrm{d}$ was used. In all analyses in which the leaky sand layer was represented (fig. 40), the interface barely reached inland of the coast in the leaky sand layer.

Four simple hydraulic conductivity distributions were hypothesized for the part of the cross-sectional grid that represented the Biscayne aquifer below the leaky sand layer. The four cases posed for analysis are: (1) $K_{x}=10,000 \mathrm{ft} / \mathrm{d}$ uniformly, (2) $K_{x}=1,000 \mathrm{ft} / \mathrm{d}$ uniformly, (3) $K_{x}=1,000 \mathrm{ft} / \mathrm{d}$ inland of the well field (fig. 40, zone 1) and 10,000 ft/d elsewhere, and (4) $K_{x}=$ $1,000 \mathrm{ft} / \mathrm{d}$ offshore and at depth (fig. 40, zone 2) and $10,000 \mathrm{ft} / \mathrm{d}$ inland in the upper part of the Biscayne aquifer. A hydraulic conductivity of $10,000 \mathrm{ft} / \mathrm{d}$ was assigned to zone 3 in all cases except case 2 . The Biscayne aquifer was assigned a vertical hydraulic conductivity 10 percent of the horizontal hydraulic conductivity $\left(K_{x}\right)$, whether the latter was 10,000 or $1,000 \mathrm{ft} / \mathrm{d}$. The hydraulic conductivities of the leaky sand layer, the semiconfining zone, and the confining zone were all considered to be horizontally and vertically isotropic.

Because of the low hydraulic conductivity assigned to the inland part of the Tamiami Formation (the semiconfining zone), convergence to an equilibrium position in this part of the aquifer was relatively slow and was not complete when the runs were terminated. However, the interface positions in the semiconfining zone shown in fig. 40 are probably within $500 \mathrm{ft}$ horizontally of the true equilibrium positions. Simulation times ranged from 120 to 180 years, and corresponding run (clock) times on the Data General Aviion $300 \mathrm{C}$ ranged from 70 to 110 hours. The maximum timestep that could be used without causing significant oscillatory behavior was 0.20 day in cases 1 


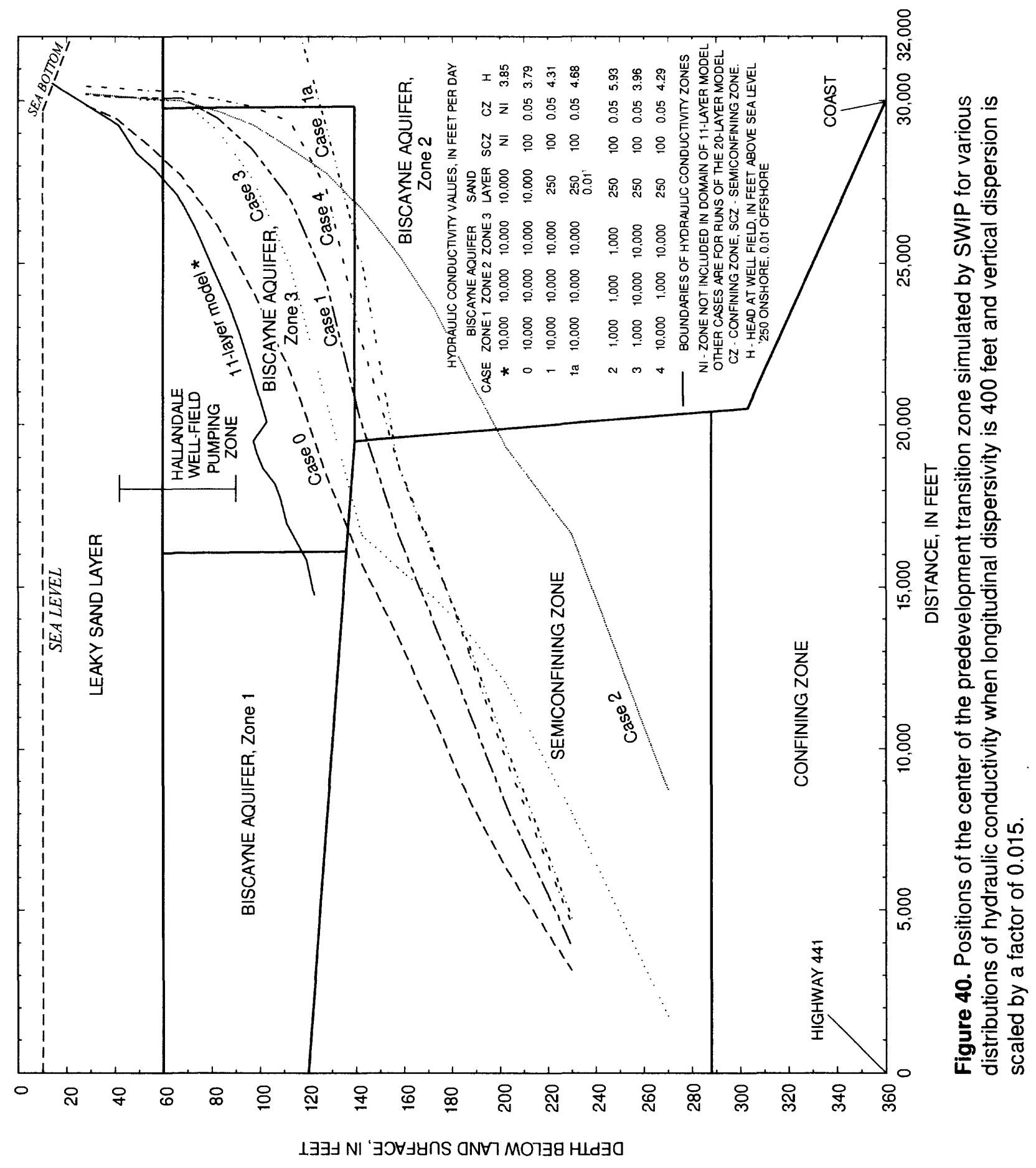


and 3 , and 0.25 day in case 4 . Because of the lower hydraulic conductivity assigned to the Biscayne aquifer in case 2 and the consequent slower rate of flow, a maximum timestep of 1.0 day was used.

Case 3 demonstrates that the equilibrium position of the 50-percent saltwater concentration line is farther inland and higher when a lower hydraulic conductivity characterizes the aquifer inland (zone 1). Case 4 demonstrates that the 50-percent saltwater concentration line is farther seaward and lower when a lower hydraulic conductivity characterizes the aquifer offshore and at depth (zone 2). When the hydraulic conductivity is uniformly lowered (case 2), the 50-percent saltwater concentration line is deeper still and even farther seaward than in the other cases, except in zone 3 . If these tests had been performed without scaling vertical dispersion, the 50-percent saltwater concentration lines would have been more vertical and farther seaward than those shown.

These results highlight the need for data describing the hydraulic characteristics of the subsurface between well fields onshore and the edge of the coastal shelf offshore where freshwater discharges and saltwater enters the ground-water flow system, particularly where a facies change in lithology can indicate a change in permeability inland of points of discharge to tidewater. However, this zone is usually saltwater intruded, and, even onshore, the cost of drilling is rarely considered to be justified. Nevertheless, if models of saltwater intrusion are to be reliable, they must be based as much as possible on real data, and this means that some effort to determine hydraulic properties of the aquifer offshore is needed.

Case 1 (in which the Biscayne aquifer zones had a uniform hydraulic conductivity of $10,000 \mathrm{ft} / \mathrm{d}$ and the overlaying sand layer and the Tamiami and Hawthorn units were represented as layers of substantially lower hydraulic conductivity) was used for a depiction of relative ground-water flow velocities (fig. 41). The vertical scale is greatly exaggerated in this illustration; therefore, velocity vectors would be nearly horizontal at true scale except in a very small region near the coastal discharge location.

Inland, flow in significant volume is simulated as being restricted to the Biscayne aquifer. Near the coast where the simulated interface, as indicated by the 50 percent concentration line, is within the Biscayne aquifer, significant flows occur above the interface. Farther toward the coast, where the Biscayne aquifer freshwater flow section thins, the velocities increase. Because the sand layer is represented as extending about $1.5 \mathrm{mi}$ seaward of the coast, freshwater must discharge in either of two ways: (1) by upward discharge through the sand layer at the coast, or (2) by moving offshore beneath the sand layer and discharging near where the sand layer pinches out. The simulation clearly indicates that for the assumed hydraulic conductivity distribution, the first scenario of discharge is the one that occurs. The horizontal grid definition in the close vicinity of the coast is not fine enough to depict the local flow system in detail, but velocities would be nearly vertical where the 50 -percent concentration line is nearly vertical.

The possibility that fresh ground water discharges to tide may occur farther offshore than indicated by the results of the analysis described above was assessed with an additional simulation (case la). Layers of the cross section representing the leaky sand layer (layers 1-5) were assigned a very low hydraulic conductivity $(0.01 \mathrm{ft} / \mathrm{d})$ where they included active nodes in the offshore section of the grid (columns 2831 ). This procedure generally represented the effect of a confining bed of sediments on the sea floor that would retard the upward circulation of freshwater. Other input parameter value assignments were as for case 1 . The result of the simulation of case la was that freshwater was depicted as circulating underneath the five upper layers and discharging at the point where the Biscayne aquifer cropped out on the sea floor (row 6 , column 32). The uppermost five layers were simulated as containing seawater offshore throughout the simulation time period. The onshore section of the simulated 50-percent saltwater concentration line is shown in figure 40 . In zone 2 , it lies somewhat below the 50-percent saltwater concentration line of case 1 . Therefore, moving the point of discharge farther offshore had only a slight effect on the interface location.

The depicted velocity distribution in the case of a leaky upper layer (fig. 41) also indicates that a deep circulation cell within the Biscayne aquifer just offshore may be induced by the freshwater discharge at the coast. The vertical exaggeration of figure 41 obscures the physical dimension of the circulation cell; in fact, the cell is about 10 times greater in horizontal dimension than it is in the vertical dimension. Inland of the coast, the direction of flow in the Biscayne aquifer below the 50-percent saltwater concentration line is in an inland direction. The velocity of flow is low and diminishes with progressive distance inland.

This offshore velocity distribution may indicate that the conventional view of the dynamics of the saltwater interface, as described by F.A. Kohout in Cooper and others (1964, p. 19), needs revision. Kohout hypothesized that slow, steady landward flow of 


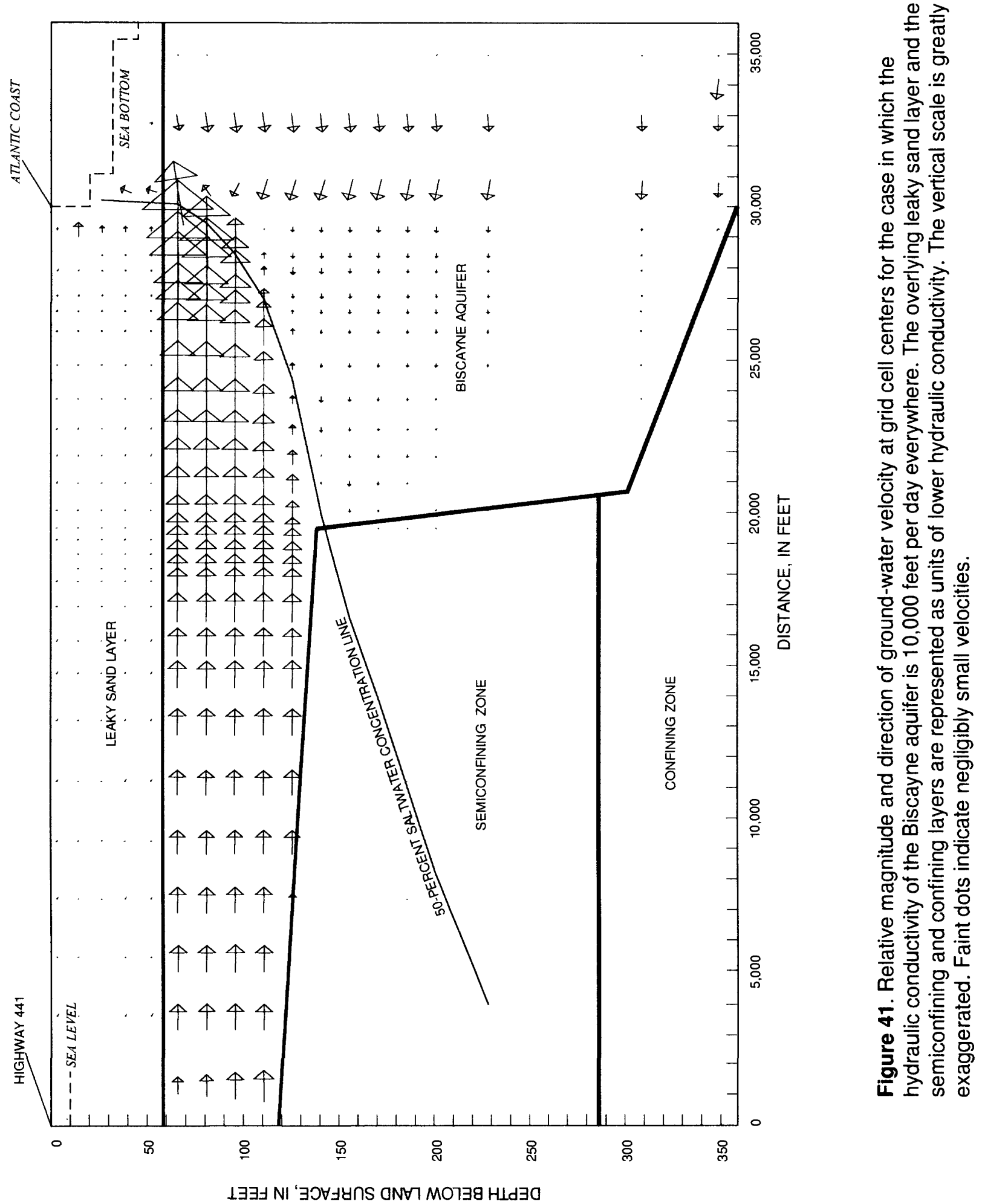


saitwater cccurred toward all parts of the interface between the toe, where the interface intersects the base of the aquifer, and the discharge location. The simulation results of this study suggest that substantially greater saltwater circulation occurs in an offshore convection cell, the inland extent of which just reaches the location of the fresh ground-water discharge to tidewater. Inland of this location, slight inland movement of saltwater toward the interface occurs in the saltwater zone, as envisaged by Kohout.

The simulation results illustrated in figure 40 do not resolve the apparent discrepancy in the observed data that was noted earlier in discussions of results of the application of the SHARP model and of the 11-layer SWIP model of an aquifer with uniform hydraulic characteristics (fig. 31). As before, the equilibrium positions of the simulated interfaces are in approximate agreement with the interface positions predicted by the Ghyben-Herzberg relation. Heads at the Hallandale Well Field simulated in cases $0,1,1 \mathrm{a}$, and 2-4 range from 3.8 to $5.9 \mathrm{ft}$, and the simulated depths to the interface were 130 to $215 \mathrm{ft}$. The problem of how to reconcile the observed average head of $1.65 \mathrm{ft}$ with the observed depth to the interface in 1981 of more than $300 \mathrm{ft}$ remains. Adding zones of known or presumed lower hydraulic conductivity (the overlying leaky sand layer and clastic layers of the Tamiami and Hawthorn Formations) to the grid did not resolve this discrepancy.

Simulated heads in the computational period leading to equilibrium were studied with a special run of case 1 in which water in the aquifer was initially assumed to be fresh inland of the coast and saline offshore. In addition, water below $290 \mathrm{ft}$ (in layers 18-20) was assumed to be saline everywhere. Layers 18 to 20 include the part of the cross-sectional grid where very low hydraulic conductivities $(0.05 \mathrm{ft} / \mathrm{d})$ were assigned to the Hawthorn Formation (confining zone), and where convergence to equilibrium would have been especially slow. This region had also previously been specified to contain saltwater when using the iterative initial condition procedure based on applying the Ghyben-Herzberg relation after each of a series of steadystate solutions. In the run now being described, the iterative initialization procedure was not used. Therefore, the initial conditions of this run were analogous to a natural situation in which high inland heads forcing the interface close to a position directly underneath the coast were instantaneously reduced at time $t=0$. The head distribution would then quickly adjust to the specified initial and boundary conditions and, in subsequent simulation times, represent the heads associated with the saltwater interface as it moved inland. The principal purpose of this run was to examine the simulated relation between head and the depth to the interface during the period when the interface moved from an initial position close to the coast to an equilibrium position.

The uniform initial head was specified to be 2.9 $\mathrm{ft}$. The specified head at the inland boundary was $5 \mathrm{ft}$. The head at the location of the Hallandale Well Field was simulated to have increased to $5.2 \mathrm{ft}$ after 100 days and to be $5.1 \mathrm{ft}$ after 1 year, $4.8 \mathrm{ft}$ after 2 years, and $4.4 \mathrm{ft}$ after 5 years. The head at the well field was previously simulated to be $4.3 \mathrm{ft}$ when near-equilibrium conditions prevailed (fig. 40, case 1).

For a more realistic representation of present-day hydrologic conditions in the area, the specified inland boundary head value was reduced from 5 to $2.5 \mathrm{ft}$. The simulated head at the well field increased from an initial value of $2.9 \mathrm{ft}$ to $4.6 \mathrm{ft}$ after 100 days, $4.5 \mathrm{ft}$ after 1 year, $4.1 \mathrm{ft}$ after 2 years, and $3.7 \mathrm{ft}$ after 5 years. A mounding of water between the inland and ocean boundaries was indicated. The degree of mounding decreased as saltwater advanced toward the well field. When the hydraulic conductivity of the leaky sand layer was increased to $2,500 \mathrm{ft} / \mathrm{d}$, the head at the well field was $3.4 \mathrm{ft}$ after 5 years; when the hydraulic conductivity of the Biscayne aquifer was also increased (to $40,000 \mathrm{ft} / \mathrm{d}$ ), the head at the well field was only 2.9 $\mathrm{ft}$ after 5 years. In the latter case, the head at the well field was $2.7 \mathrm{ft}$ after 40 years, at which time the saltwater interface had risen higher than $100 \mathrm{ft}$ below land surface at the well field. This run was repeated using the standard algorithm for vertical dispersion, which previously had led to a portrayal of a nearly vertical interface (fig. 37). The simulated head at the Hallandale Well Field was initially $2.8 \mathrm{ft}$ and then increased to $4.8 \mathrm{ft}$ by 100 days. It decreased to $2.9 \mathrm{ft}$ after 5 years and to $1.9 \mathrm{ft}$ after 40 years. The transition zone was very broadly dispersed, and water in the pumping zone at the well field was simulated as having more than 50 percent of the concentration of saltwater after 40 years.

Clearly, the simulated head at the well field quickly assumes a value higher than the value associated with the equilibrium interface position and decreases with increasing simulation times as the interface approaches its equilibrium position. The simulated heads are consistent with the depth to the interface indicated by the Ghyben-Herzberg relation after the higher head value is reached; the heads then decrease as the interface reaches farther inland and rises higher in the aquifer. At no time during the computational sequences described above were simulated heads lower than $1.9 \mathrm{ft}$ at the well-field location. Therefore, it seems unlikely that the low heads measured near the well field between 1970 and 1994 (table 1) could represent a preequilibrium state of the system 
as the interface moved toward an equilibrium position, given the assumption of uniform easterly flow toward an offshore discharge area and the estimated hydraulic conductivity values. It is probable that the conceptual model of easterly flow toward an offshore tidal discharge area will require revision.

The simulations of this section have shown that varying the spatial distribution of hydraulic conductivity can appreciably alter the position of the freshwater/ saltwater interface at equilibrium. However, the various simulations approximately agreed with the Ghyben-Herzberg relation between head and the interface position, and therefore, do not replicate the field data that differ substantially from the Ghyben-Herzberg relation. Because most of the simulations of the predevelopment equilibrium position of the interface are landward of the current position, the simulations are inconsistent with field data. When preequilibrium interface positions, starting with a vertical interface at the coast, were studied, simulated heads at the Hallandale Well Field were higher than the head at equilibrium and continued to be in approximate agreement with the Ghyben-Herzberg relation. Simulated preequilibrium relations between head and the depth to the interface were still inconsistent with field data.

When the sand and sandstone layer overlying the Biscayne aquifer was simulated as being leaky everywhere, freshwater discharge to tidal water was upward through the sand and sandstone layer at the shoreline. When the sand and sandstone layer was represented as being nearly impermeable offshore, freshwater discharge occurred at the outcrop of the layer at the Atlantic Shelf. However, the onshore position of the interface at equilibrium was similar to those simulated when the sand and sandstone layer was represented as being leaky and was also inconsistent with field data.

\section{Relation of Interface Position to Saltwater Density}

The position of the interface between freshwater and saltwater was indicated by analyses with the SHARP code to be partly related to the density of the body of saltwater. It is the greater weight of saltwater relative to freshwater that causes the saltwater to wedge farther inland with depth below sea level, until a position is reached where the freshwater head is high enough to balance the saltwater head at that depth.

Data describing the salinity of oceanic water off the coast of southern Florida is not usually acquired in marine studies because it is not expected to show variation (Dr. J. Wang, Rosensteil School of Marine and Atmospheric Sciences, Miami, Fla., oral commun., 1994). Brooks and Niiler (1977) show the distribution of salinity and density in a cross section of the Straits of Florida between Miami Beach and the Great Bahama Bank to be relatively uniform laterally. However, it is the salinity of water near the presumed outcrop of the Biscayne aquifer at the Atlantic Shelf, or within about $2.5 \mathrm{mi}$ of the shore (fig. 39), that could affect the position of the interface. Only two of the measuring stations used by Brooks and Niiler (1977) are within this distance of the coast. Within or near the study area, streams or canals such as New River, the Dania Cutoff Canal, and Snake Creek Canal discharge freshwater to the Intracoastal Waterway, which empties into the ocean through Port Everglades Inlet or Bakers Haulover Cut (fig. 7). The discharge is greatest during the summer wet season when most rainfall occurs. It might be hypothesized that the volume of fresh summer discharge or rainfall directly on the ocean surface could cause a seasonal or permanent decrease in the salinity of near-shore ocean water sufficient to affect the position of the interface in the Biscayne aquifer.

This possibility was tested in sensitivity analyses analogous to the one performed using SHARP. By using SWIP, however, the lower permeabilities of the leaky sand layer and semiconfining and confining zones could be represented, and a transition zone could be simulated. The control, or reference simulation, for the analyses was the previous case (figs. 40 and 41 , case 1) in which the hydraulic conductivity of the Biscayne aquifer was uniform at a value of 10,000 $\mathrm{ft} / \mathrm{d}$, the lower permeabilities of the leaky sand layer and semiconfining and confining zones were represented, the longitudinal and vertical dispersivities were $400 \mathrm{ft}$ and $0.1 \mathrm{ft}$, respectively, and the scaling factor for vertical dispersion was 0.015 .

Results agree with results of the SHARP analysis in that when a reduction in the saltwater salinity (density) is specified, the 50-percent saltwater concentration line, used to indicate the approximate center of the interface, is below and seaward of its position when a higher density is specified. When the saltwater density $\left(63.13 \mathrm{lb} / \mathrm{ft}^{3}\right)$ is greater than that of freshwater by only half the difference with standard seawater $\left(64.0 \mathrm{lb} / \mathrm{ft}^{3}\right)$, the displacement of the 50 -percent saltwater concentration line is substantial (fig. 42). However, if ocean water density near the coast of peninsular Florida were less dense than standard seawater for all or part of the year, the difference would probably not be this great. Therefore, a second analysis was performed in which the saltwater density was reduced by 10 percent of the difference between freshwater and standard seawater. Results (fig. 42) indicate that the location of the 50 percent saltwater 


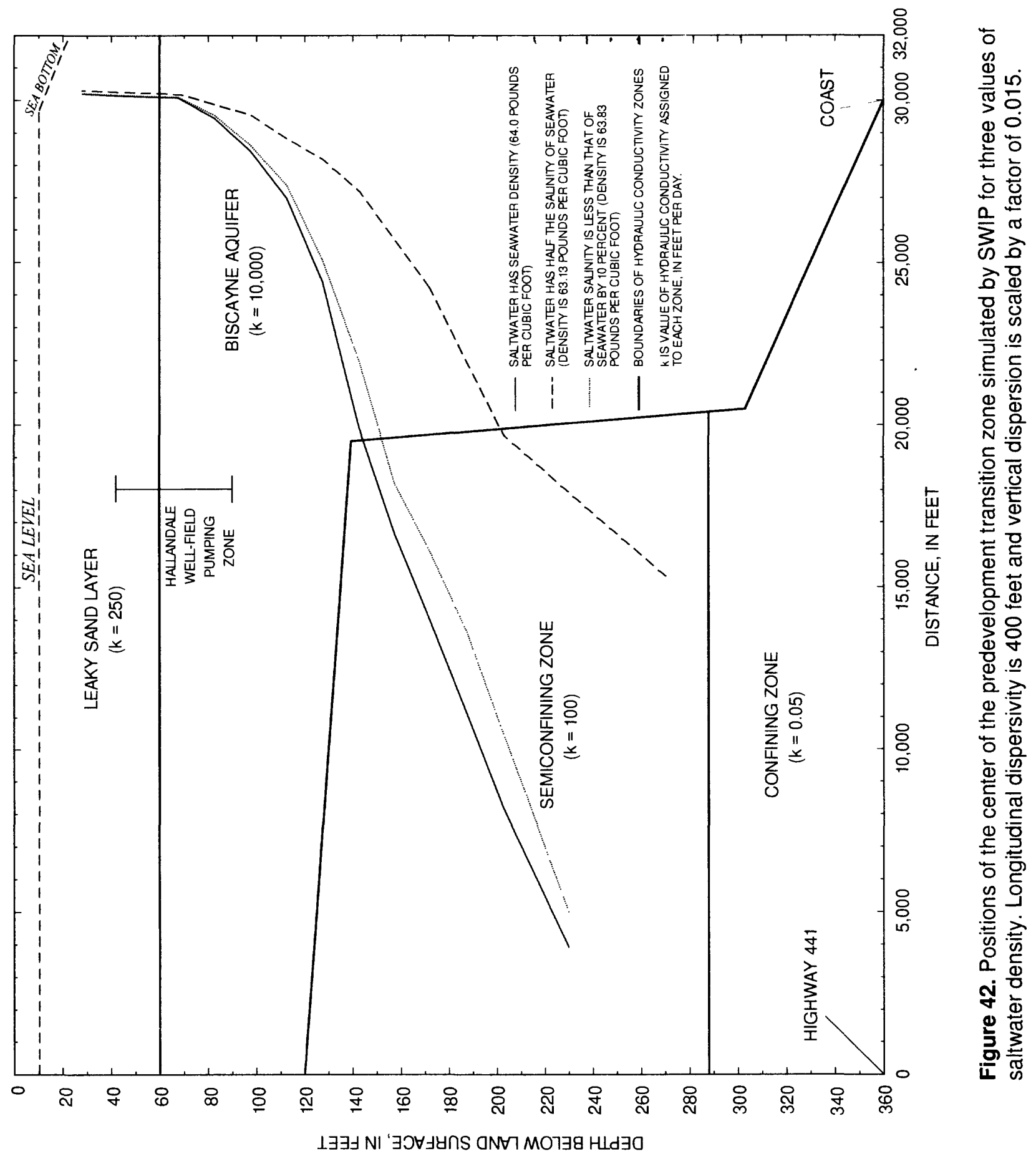


concentration line might be about $10 \mathrm{ft}$ lower than in the case used for control. This is not large compared to the variation in the position of the simulated interface that results from variations in specifications of dispersivity, vertical dispersion scaling, and the hydraulic conductivity distribution. It is concluded, therefore, that the interface position is not highly sensitive to small variations in seawater density.

\section{Effect on Interface Position of Seasonally Varying Recharge and Evapotranspiration Rates}

The predevelopment equilibrium position of the interface between freshwater and saltwater has previously been represented as being determined by nonvarying hydraulic conditions. This would seem to be an acceptable assumption because the interface has been simulated in cross section as moving very slowly toward its equilibrium position, and simulation times have ranged upwards of 10 years. However, the prevailing hydraulic conditions in the study area generally are not in true equilibrium, but show marked seasonal and episodic variations. It is of interest to determine whether these variations in hydraulic conditions can affect the equilibrium position and degree of dispersion of the interface and whether temporal variations in the position of the interface are of significant magnitude.

Kohout and Klein (1967) hypothesized that the pulse nature of recharge to the highly permeable surficial Biscayne aquifer of southern Florida would significantly affect the position of the interface at equilibrium. "Pulse recharge" refers to the fact that the majority of recharge to the aquifer occurs in the form of storms of short but intense duration that rapidly raise the water table and are followed by more lengthy periods of ground-water recession caused by evapotranspiration and drainage to tidewater. The effect of pulse recharge on the interface position would be best simulated numerically by the explicit representation of the pattern of recharge from a series of storms and the corresponding variation of boundary head values. A more generalized and possibly less effective approach to the simulation of pulse recharge would be to consider the average seasonal pulse effect that occurs in the study area because 71 percent of average total annual rainfall falls during the summer wet season (May-October). This latter approach is more amenable to representation in SWIP than the explicit representation of a series of actual storms because SWIP has been modified by the author to have an option to input monthly recharge rates, maximum evapotranspiration rates, and boundary head values (seasonal format). Therefore, this partial test of Kohout's hypothesis was the one performed as part of this study.
The parameter value specifications used in these simulations were as previously described for case 1 (figs. 40 and 41 ). The nonvarying boundary head values $(5 \mathrm{ft}$ at the inland end of the cross section and 0.75 $\mathrm{ft}$ at the ocean end of the cross section) and timeinvariant rainfall and maximum evapotranspiration rates $(0.0141$ and $0.0136 \mathrm{ft} / \mathrm{d})$ of the previous analyses were entered into the model using the seasonal format (though the values did not vary) and run for a simulation time period of 185 years, much longer than needed to achieve convergence. A comparison of the equilibrium 50-percent concentration line with that simulated using the normal specification of constant average conditions revealed that they were virtually identical. Results of this simulation using the seasonal input format were then used as a control for a test of the effects of seasonal variation.

A representative seasonal variation of the inland head boundary condition ranging from 4 to $6 \mathrm{ft}$ and averaging exactly $5 \mathrm{ft}$ was subsequently entered into the model. The specified seasonal variation of the head at the ocean boundary was based on long-term monthly averages of tidal head data (table 1) measured by the USGS in the Intracoastal Waterway at Hollywood (fig. 7). Slight adjustments were made so that the annual average of the monthly average heads would be exactly $0.75 \mathrm{ft}$. Monthly recharge rates based on rainfall data from the Fort Lauderdale Airport and the monthly maximum evapotranspiration rates used to simulate the flow system in the Biscayne aquifer in southern Dade County (Merritt, 1996b) were also used as input specifications. The averages of these monthly rates were the nonvarying rates used in previous analyses and cited above. Using the new seasonally varying rates, the previous run was resumed from a restart record written at a simulation time of 160 years and continued for an additional 43 years of simulation time. A list of annual water-budget values, monthly head values, and the solute concentration field was obtained for the last 3 simulation years.

The transition zone is wider and moves seasonally when recharge, evapotranspiration, and boundary conditions vary seasonally (fig. 43 , solid and dashed lines), but the contrast with the transition zone simulated using time-invariant rainfall, evapotranspiration, and boundary conditions (fig. 43 , dotted lines) is slight. The contrast is greatest where the transition zone is most nearly horizontal, in the deepest part of the Biscayne aquifer occupied by the interface (between 20,000 and 25,000 ft in fig. 43). Here, the vertical thickness between the 25 - and 75 -percent concentration lines is as little as $20 \mathrm{ft}$, and the seasonal migration of the interface is about $5 \mathrm{ft}$ vertically. 


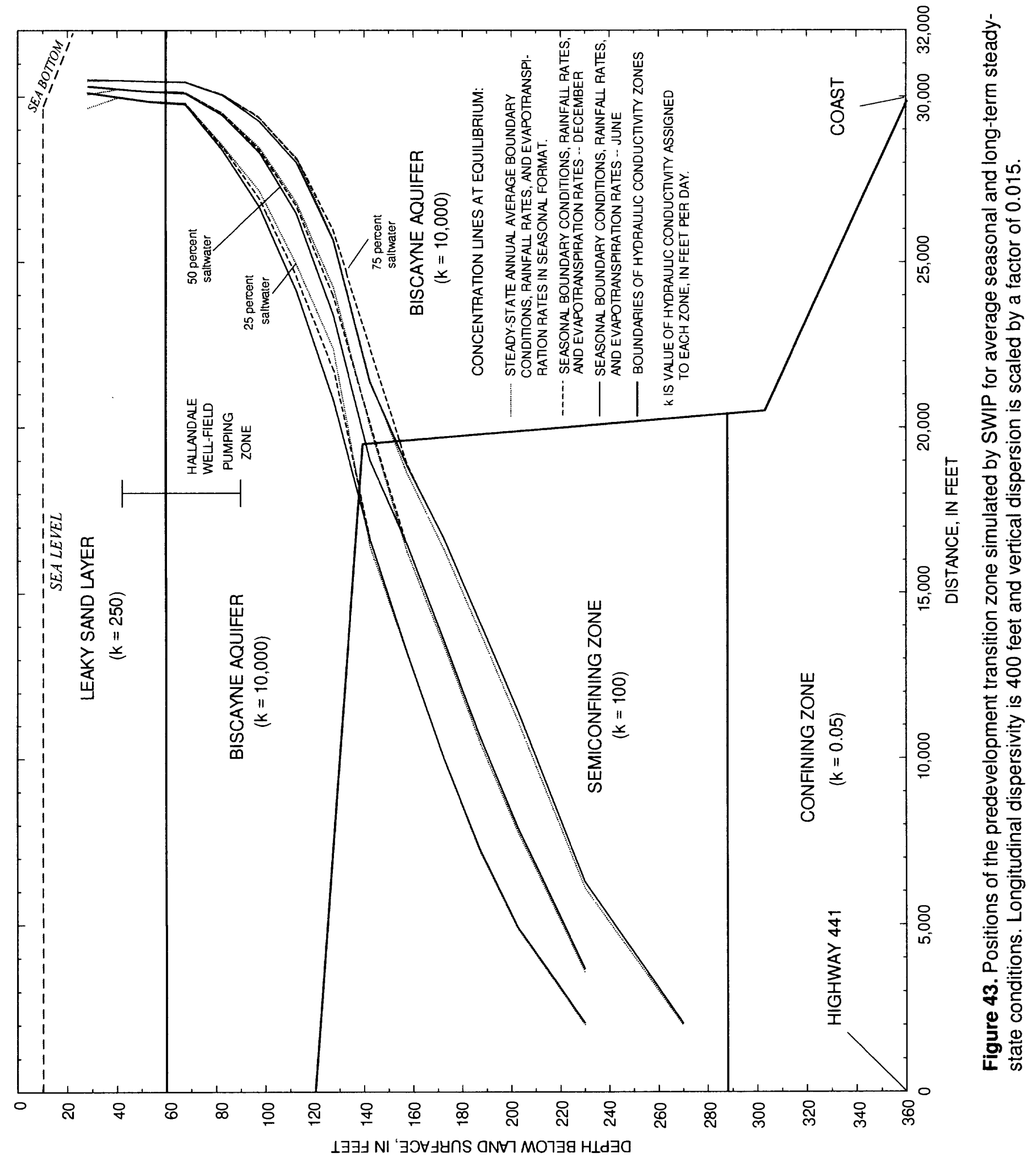


The interface position is higher between May and July after the low water table of the dry season and lower between October and December after the high water table of the wet season. The simulated positions of the 25-, 50-, and 75-percent saltwater concentration lines are in long-term equilibrium in the run with seasonally varying conditions; the simulated positions are identical within $1 \mathrm{ft}$ in the month of October in the 200th, 201 st, 202nd, and 203rd simulation years of the run. It is noted that because the simulated interface is nearly horizontal in the region of its greatest seasonal movement, the slight vertical movement is equivalent to a horizontal displacement of as much as $1,000 \mathrm{ft}$.

Water-budget values computed for the steadystate and time-varying seasonal simulations were examined to determine whether the time-varying specifications could have caused a different degree of longterm hydraulic stress to the simulated flow system sufficient to affect the result of the comparison. In each run, the net annual recharge (rainfall minus evapotranspiration) and the net cross-boundary water flux were virtually the same in consecutive years (differing by less than 0.07 percent for net recharge and less than 0.02 percent for boundary flux) and were in almost exact balance with one another (differing by less than 0.18 percent in either run or either year). However, the difference in the amount of annual net recharge is about 2.0 percent between steady-state and time-varying runs, and the difference in the net boundary flux is about 1.9 percent between the runs. The slightly higher values are for the run with nonvarying conditions. Because water-budget elements are in balance in each run and differ only slightly between runs, it seems likely that the comparison runs are valid as a sensitivity analysis of the effect of seasonally varying conditions.

The simulated concentration fields for the timesteps used for the water-budget comparisons were also examined. In both runs, density values in the onshore part of the saltwater zone ranged up to 5 percent higher than that specified for saltwater as a result of the cumulative effect of slight spatial oscillations. However, the affected zone was narrower in the timevarying run. Though the effect was slight, the greater weight of the saltwater in the steady-state run might cause the steady-state interface to be slightly farther inland than it would otherwise be if saltwater-zone concentrations were the same in both simulations. However, because the steady-state interface was slightly seaward of the time-varying one, the difference in saltwater-zone densities either made little difference or was countered by a stronger influence related to the representation of seasonally varying conditions.
The general conclusion from the foregoing analyses is that the use of seasonally varying boundary conditions and rainfall and evapotranspiration rates had little effect on the position of the simulated interface, and caused only a slight seasonal variation in the simulated position of the saltwater interface in the highly permeable Biscayne aquifer. This suggests that the influence of seasonal and episodic variations of hydrologic conditions does not significantly affect the actual interface position. However, and particularly if the transition zone is quite narrow, a sampling well with a short open interval located near the transition zone might show substantial seasonal variation in the chloride concentrations of water samples, which nevertheless would not indicate substantial seasonal movement of the interface. In this case, pumping to obtain water samples might have an effect on the salinity of the water samples because of the proximity of the sampling point to saline water.

\section{Sensitivity Analyses in a Hypothetical Layered Aquifer System}

Because results cited in the previous sections indicated the importance of the hydraulic conductivity distribution in determining the position of the saltwater interface and because the shallow subsurface in the study area is known to be highly layered, sensitivity analyses were made in a SWIP representation of a highly layered aquifer so that the effect of representing layered strata as a hydraulically uniform zone could be assessed. In addition, the different simulated distributions of freshwater and saltwater resulting from the use of various computational algorithms applied to a highly layered aquifer representation were studied.

A hypothetical sequence of layers characterized by distinct hydraulic properties was proposed (fig. 44) to describe the aquifer system for the analyses. In actuality, this sequence was not completely hypothetical, but was based closely on the solution porosity log (app. 3) prepared by J.E. Fish and M.L. Merritt and based on rock samples from test hole G-2328 (fig. 18) drilled in the Hallandale Well Field in 1981. Values of horizontal and vertical hydraulic conductivity were assigned to layers of varying thickness based on visual inspection of the rock samples. This was a subjective procedure; however, because results of these analyses were to be used to study the behavior of the model and were not used for predictive purposes, the accuracy with which the layered model that resulted from this procedure replicated nature was not an issue.

As figure 44 illustrates, the layering was assumed to be extensive, with some exceptions. As in previous 


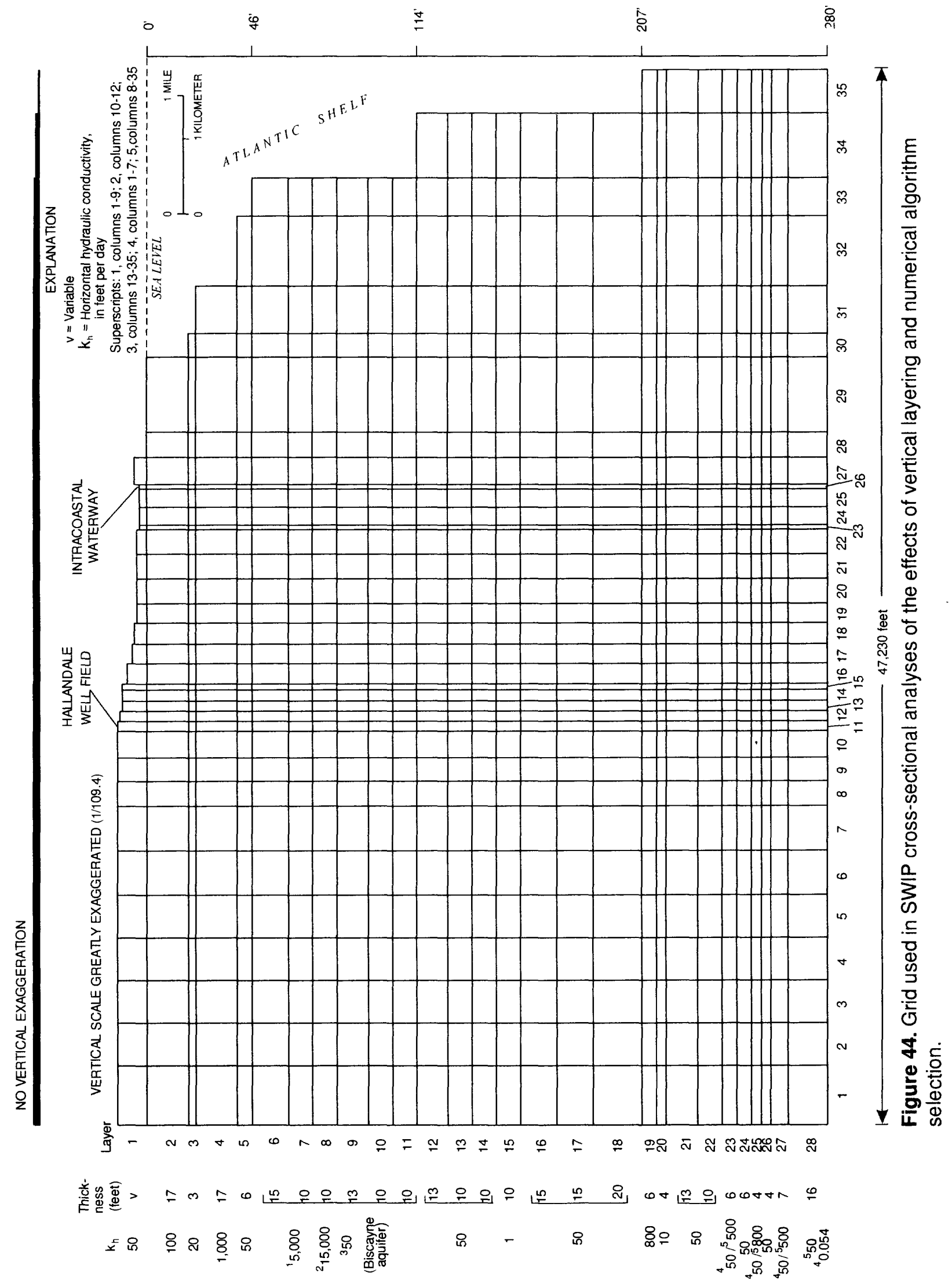


SWIP applications, the section modeled in cross section extended from Highway 441 to an outcrop on the edge of the Atlantic Shelf. The shelf was represented explicitly based on offshore depth charts, as in previous SWIP model grids. There were 28 layers in the grid. The upper five layers, about $50 \mathrm{ft}$ in combined thickness, generally represented the semiconfining zone of clastic sediments (leaky sand layer) that overlies the Biscayne aquifer in the study area. A 17-ft layer of the model within this zone (layer 4) was now used to represent a sandstone layer more permeable than the rest of the semiconfining zone. The next six layers (layers 6-11), $68 \mathrm{ft}$ in combined thickness, represented the Biscayne aquifer. This unit was assigned horizontal hydraulic conductivities of $5,000 \mathrm{ft} / \mathrm{d}(\mathrm{col}-$ umns 1-9), 15,000 ft/d (columns 10-12), and $50 \mathrm{ft} / \mathrm{d}$ (columns 13-35). The high second value reflected the assumption that the aquifer is especially permeable in the neighborhood of the well field (column 11) by virtue of the presence of a prehistoric reef tract (Key Largo Limestone). The low third value represented an attempt to enhance the simulation of predevelopment conditions by assuming that the Biscayne aquifer grades into materials of low permeability east of well G-2328 in the Hallandale Well Field. On the basis of evidence acquired since this hypothetical model was postulated in the early 1980's (fig. 4 and apps. 1-3, cores from test holes G-2610 and G-3472), the Biscayne aquifer is now known to extend at least to the Intracoastal Waterway, but this should not affect results of the sensitivity analyses.

A 93-ft section below the Biscayne aquifer was divided into seven layers (layers 12-18) that represented an interval of sand or sandstone with limestone nodules in the upper part of the Tamiami Formation. The sand layers were assigned horizontal and vertical hydraulic conductivities of $50 \mathrm{ft} / \mathrm{d}$. The depth interval also contained a 10-ft layer of hard, dense limestone of low permeability that was arbitrarily assigned a horizontal hydraulic conductivity of $1 \mathrm{ft} / \mathrm{d}$. The lower $76 \mathrm{ft}$ of the section was divided into 10 alternating layers (layers 19-28) of moderate (500-800 ft/d) and low (50 $\mathrm{ft} / \mathrm{d}$ ) hydraulic conductivity as indicated by the aquifer lithology at well G-2328. This characterization was expected to be useful in studying the effect of layering. The layers of moderate hydraulic conductivity were assigned the lower hydraulic conductivity $(50 \mathrm{ft} / \mathrm{d})$ in columns 1-7 to reflect the lack of evident layering in rock samples from test hole G-2327 to the west of G-2328 (fig. 4). The bottom layer was considered to be nearly impermeable in columns 1 to 7 by assigning horizontal and vertical hydraulic conductivities of $0.05 \mathrm{ft} / \mathrm{d}$. This is because the clayey Hawthorn Formation is present at this depth in G-2327 (Causaras,
1985). In all (nonsand) layers with horizontal conductivities other than $50 \mathrm{ft} / \mathrm{d}$, assigned vertica! hydraulic conductivities were 10 to 25 percent of the horizontal hydraulic conductivities.

Freshwater and saltwater density specifications were 62.4 and $64.0 \mathrm{lb} / \mathrm{ft}^{3}$, respectively, as in previous simulations with the SWIP code, isothermal conditions at $70^{\circ} \mathrm{F}$ were assumed, and effective porosity was 20 percent in all layers. Unlike the previous simulations, the time-invariant boundaries at the ends of the cross section were assigned entirely hypothetical head values of $8.5 \mathrm{ft}$ at the inland boundary and $0.0 \mathrm{ft}$ (sea level) at the ocean boundary. Parameter value specifications for rainfall and evapotranspiration were hypothetical and differed from that of the 20-layer model runs. The effect of the specified rates was that the evapotranspiration rate exceeded the recharge rate $(60$ in/yr) by 4.5 percent. The water-budget deficit was made up for by inflows across the inland boundary.

Using the hydraulic conductivities just described, the model was run for a simulation time of 400 years. As in earlier simulations, the initial position of the interface was chosen in a successive series of steadystate solutions for pressure in which grid cells in vertical columns were assigned freshwater or saltwater densities depending on whether they were above or below the theoretical Ghyben-Herzberg depth.

As before, all lines of equal concentration within the transition zone converged to an equilibrium position as shown for the 50-percent saltwater concentration line in figure 45 . Little change in the position of the 50 -percent saltwater concentration line in any hydraulic layer occurred after 300 years. Because the interface movement was in a zone with relatively low hydraulic conductivity, the rate of flow was slow and the maximum allowable time-step length was a relatively large 1.0 day. Unlike the case of previous SWIP simulations, the interface moves seaward toward its equilibrium position; this is probably only a result of the choice of initial position and parameter values. The position of the Ghyben-Herzberg line based on the head distribution at 400 years is also shown in figure 45 , and is landward of the final position of the 50 percent concentration line. The 50-percent saltwater concentration line is farthest seaward of the GhybenHerzberg line in intervals where the hydraulic conductivity is highest.

A second run was performed in which the initial position of the interface was a vertical line between columns 27 and 28 of the grid (fig. 44), or at the Atlantic Ocean shore. As shown in figure 46 , the 50 -percent 


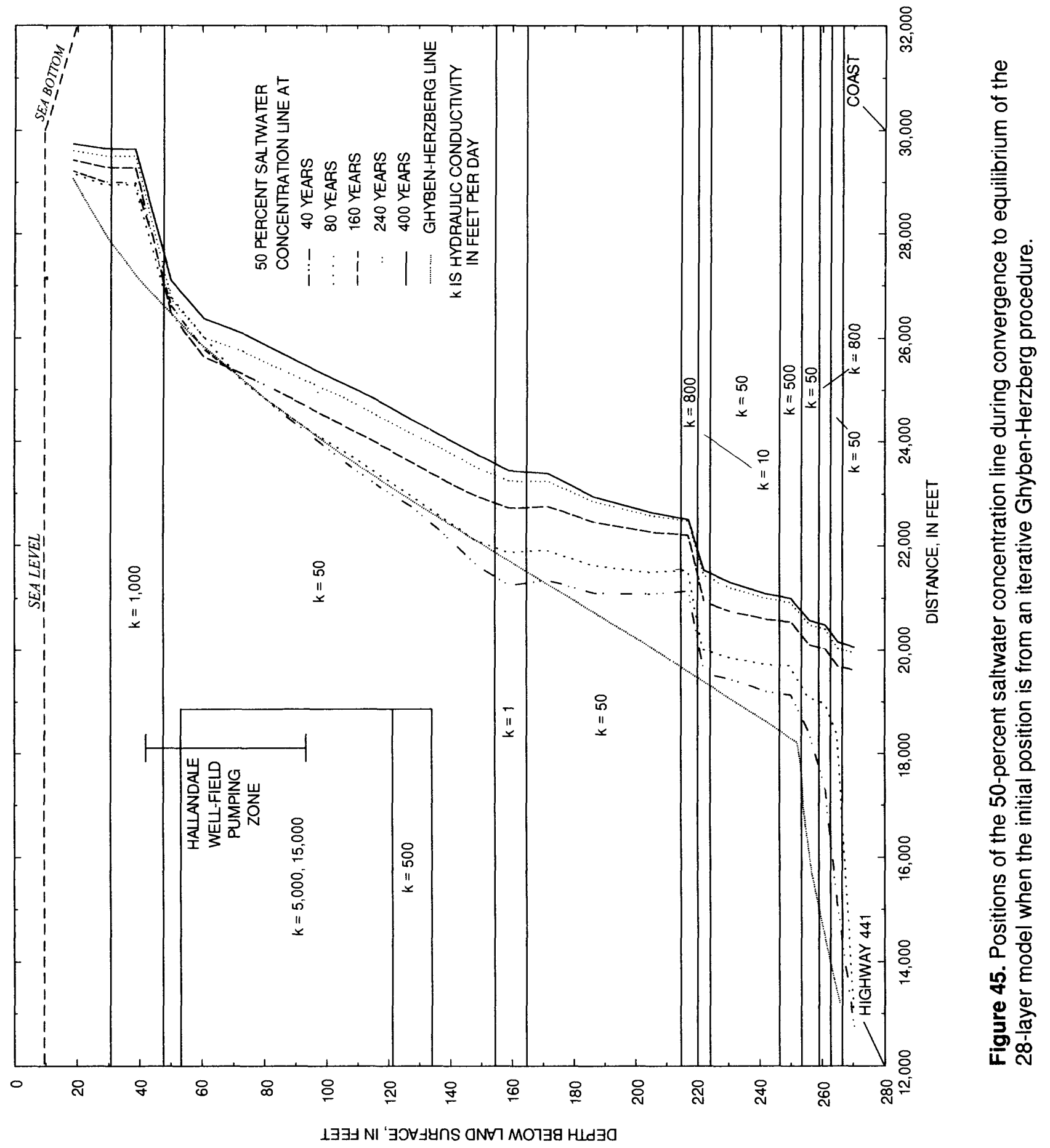


saltwater concentration line moves progressively inland until, as before, it converges to an equilibrium position. Changes in the slope of the line are related to the layering of hydraulic conductivity, as before. The equilibrium position is inland of its counterpart from the previous set of runs (fig. 45). The 50-percent saltwater concentration lines differ by a maximum of less than $700 \mathrm{ft}$ at the base of the cross-sectional grid (fig. 47). A study of the solute fraction fields simulated at the end of the run starting with the vertical-line approximation showed values ranging as high as 110 percent of that specified for saltwater as a cumulative result of oscillatory behavior in the 400 years of solute-transport calculations. Because the mass of the water on the saltwater side of the interface is heavier than that of the saltwater in the run starting with the Ghyben-Herzberg position (where saltwater concentrations in the equilibrium solution generally were about 100 to 104 percent of that specified for saltwater), the equilibrium position of the interface is farther inland, even while demonstrating the same correlation with the hydraulic conductivity layering as in the earlier case. This is consistent with results of the previously cited sensitivity analyses that considered possible variations in the density of ocean water.

The effect of hydraulic conductivity layering is evident in the change of slope of the 50-percent saltwater concentration line at vertical intervals where the hydraulic conductivity changes substantially. Apparently, the more rapid flow that occurs in the zones of higher hydraulic conductivity causes the interface to be pushed slightly seaward relative to adjacent zones of lower hydraulic conductivity. This is evident in the zones with a specified hydraulic conductivity of 500 or $800 \mathrm{ft} / \mathrm{d}$ at 218,250 , and $262 \mathrm{ft}$ below land surface, and in the zone at $40 \mathrm{ft}$ below land surface where the hydraulic conductivity is $1,000 \mathrm{ft} / \mathrm{d}$. On the other hand, there is an inland bulge of saltwater in the $10-\mathrm{ft}$ thick zone at $160 \mathrm{ft}$ below sea level where the hydraulic conductivity is $1 \mathrm{ft} / \mathrm{d}$. The slope of the interface, as indicated by the 50 -percent saltwater concentration line, is more horizontal in layers of higher hydraulic conductivity and more vertical in layers of lower hydraulic conductivity. These effects are relatively minute in spatial extent in these examples, but it seems that the effect of hydraulic conductivity layering could appreciably affect the location of the interface if the layers were much thicker than they are in this example.

In all of the foregoing analyses, a longitudinal dispersivity of $400 \mathrm{ft}$ was specified, and transverse dispersivity was zero. The modified algorithms for vertical dispersion and advection were used. This means that vertical dispersion between layers of different hydraulic conductivity did not occur, and vertical dispersion between adjacent layers having the same hydraulic conductivity $(50 \mathrm{ft} / \mathrm{d}$ in the region of interface movement) was scaled. In these runs, the scaling factor was 0.008 , the ratio of the average vertical and horizontal grid dimensions.

At this stage, two sensitivity analyses were performed to determine how results of the simulation would be affected by the specification of a more generalized hydraulic conductivity layering. All model layers (12-28) below the Biscayne aquifer were considered to belong to two hydraulic units, each characterized by a single horizontal and vertical hydraulic conductivity. The first unit extended to $215 \mathrm{ft}$ below land surface and was assigned a horizontal hydraulic conductivity of $50 \mathrm{ft} / \mathrm{d}$. The only change from the previous representation was the elimination of the $10-\mathrm{ft}$ layer of low hydraulic conductivity between 155 and $165 \mathrm{ft}$. The alternating layers of moderate and low conductivity between 215 and $280 \mathrm{ft}$ were assigned a horizontal hydraulic conductivity value of $223 \mathrm{ft} / \mathrm{d}$, a value that is a weighted average based on layer thickness and the previously assigned hydraulic conductivity values. Vertical hydraulic conductivities were 10 percent of the horizontal values.

The first sensitivity analysis was conservative in that no vertical dispersion was permitted to occur across layers where it previously had not occurred. This was done by assigning minute variations to the horizontal hydraulic conductivities of adjacent layers where significant variations were present in the previous representation. The result (fig. 48) shows the difference in the configuration of the 50-percent saltwater concentration line that is strictly related to simplifying the vertical distribution of hydraulic conductivity and not caused by changes in computational algorithms. The simulated 50-percent saltwater concentration lines are separated by no more than about $500 \mathrm{ft}$. The new equilibrium 50-percent saltwater concentration line is smoother and shows fewer slope discontinuities than before. A slight slope discontinuity occurs at the boundary between the 50 and $223 \mathrm{ft} / \mathrm{d}$ hydraulic conductivity zones. The slope appears more vertical in the $50-\mathrm{ft} / \mathrm{d}$ zone than in the $223-\mathrm{ft} / \mathrm{d}$ zone.

In the second sensitivity analysis, the minute variations of hydraulic conductivity between adjacent zones within the same hydraulic units were eliminated. This permitted scaled vertical dispersion to occur throughout those units, although the scaling factor was rather small $(0.008)$. Only slight variations from the previous case were noted. A straightening of the 50-percent saltwater concentration line at $170 \mathrm{ft}$ in 


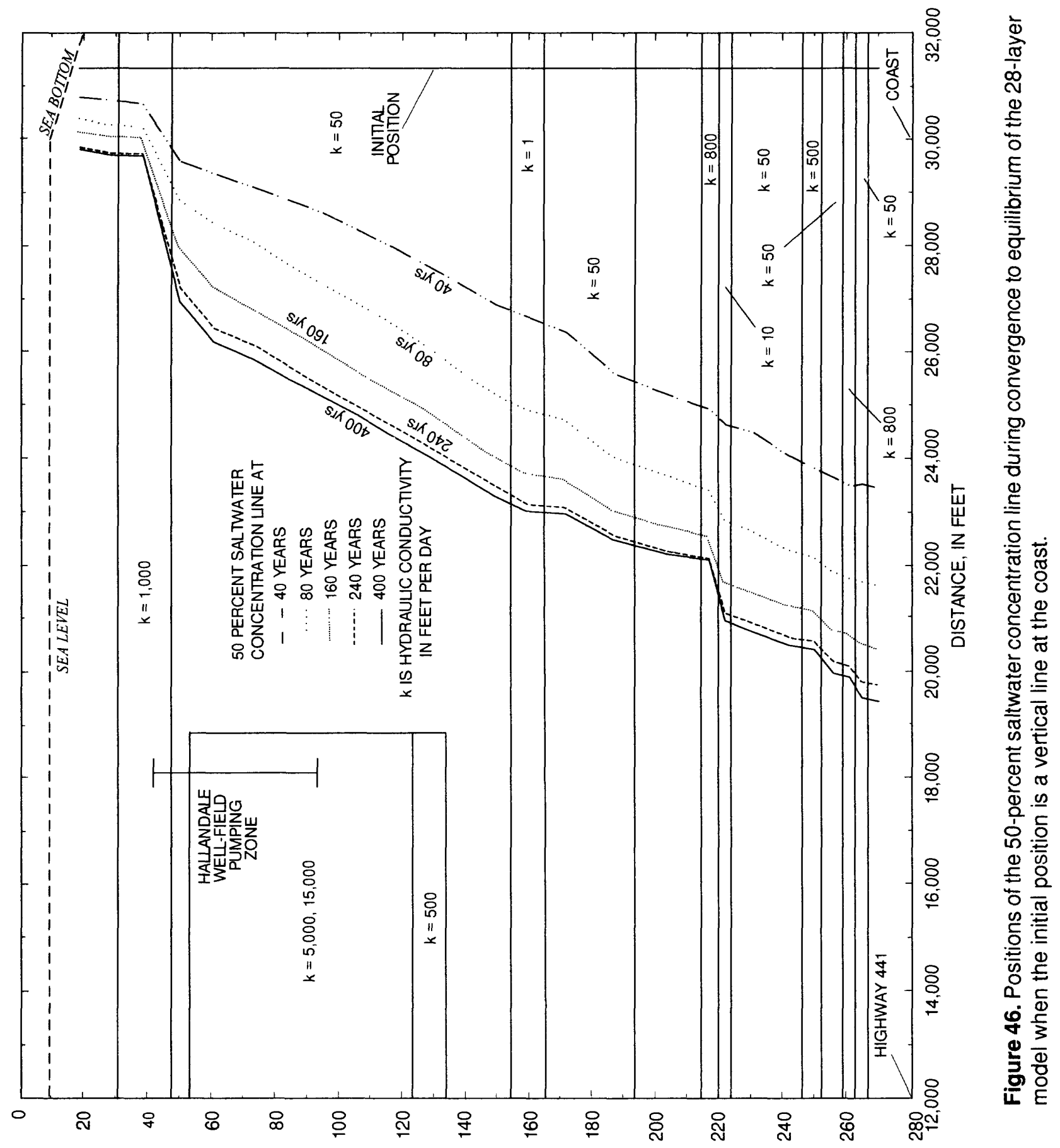

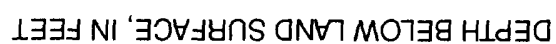




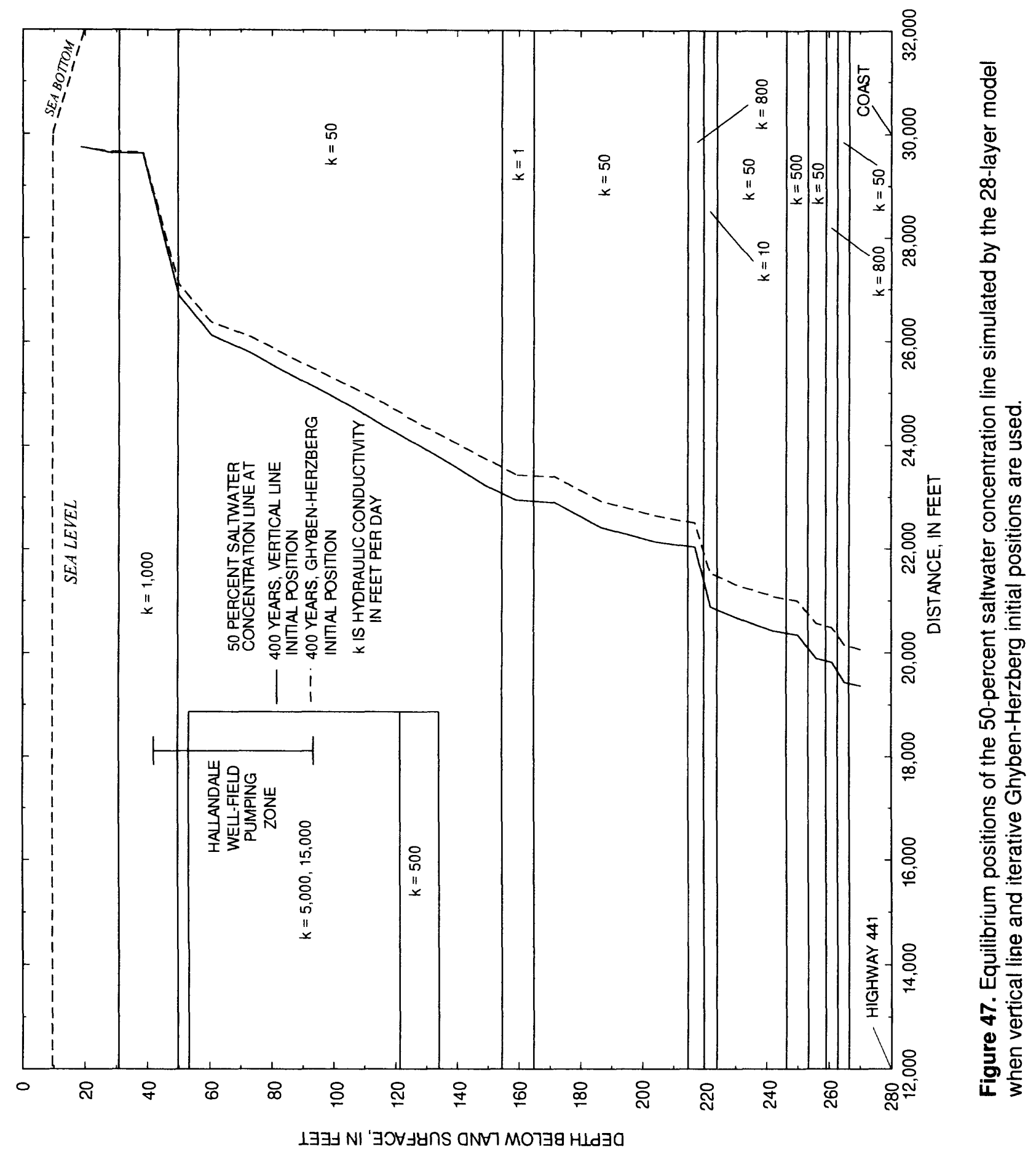




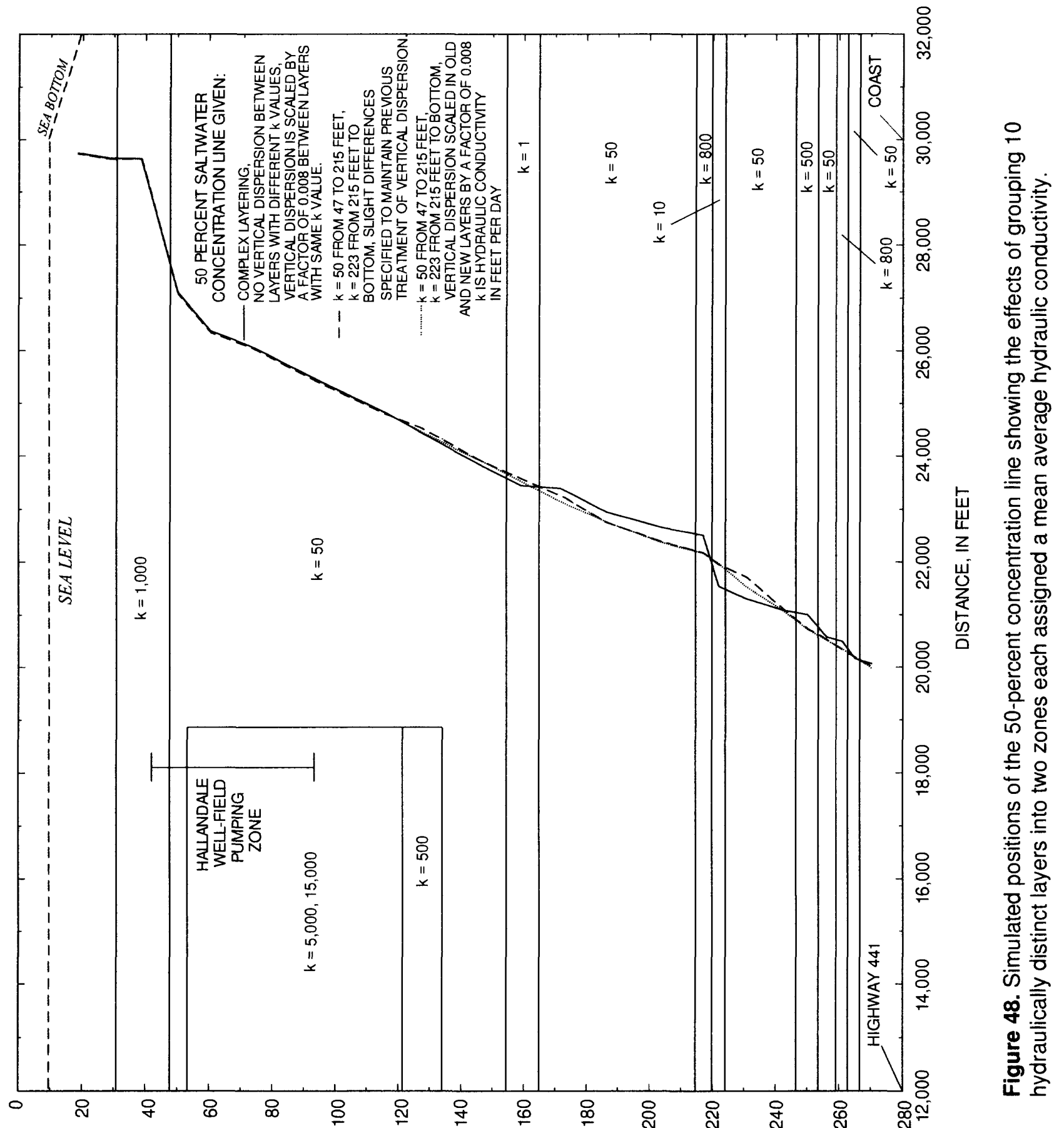

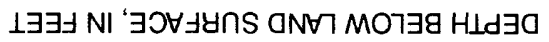


the zone where hydraulic conductivity is specified to be $50 \mathrm{ft} / \mathrm{d}$ and at $230 \mathrm{ft}$ in the zone where the hydraulic conductivity is specified to be $223 \mathrm{ft} / \mathrm{d}$, are evident.

These analyses seem to indicate a result that applies to steady-state simulations. Apparently, lumping thin layers of contrasting hydraulic conductivity by the common assignment of hydraulic conductivities that are a thickness-weighted average of layer conductivities leads to a simulated interface that is similar to one based on a detailed specification of individual layer conductivities. This is a useful result because it indicates that the vertical layering of horizontal hydraulic conductivity can be simplified for the purpose of reducing the dimensions of model grids and the correlative costs of computer processing. This result might not apply to transient simulations in which a disturbance of a previous equilibrium state could cause relatively rapid saltwater movement in thin zones of comparatively higher hydraulic conductivity.

The relation between the choice among optional dispersion algorithms and the simulated position of the equilibrium interface was explored with a set of comparison runs in which different algorithms were used and longitudinal and transverse dispersivities were varied. The standard treatment of vertical dispersion, as coded in the version of SWIP documented by INTERA Environmental Consultants, Inc. (1979), was used in some runs. In other runs, the modified algorithms that exclude the representation of vertical dispersion between layers of different hydraulic conductivity and that scale vertical dispersion between layers having the same hydraulic conductivity were used. In some of the latter runs, the scaling factor was 0.008 . In other runs using the modified algorithms, vertical dispersion between layers having the same hydraulic conductivity was not scaled (the scaling factor was set to 1.0 ). The longitudinal dispersivity values used in this series of runs were 400,40 , and $4 \mathrm{ft}$. Transverse dispersivity was set to zero in these runs. Nonzero transverse dispersivity values were used in a later set of sensitivity analyses.

The differences in the positions and shapes of the simulated equilibrium interfaces among the various algorithms used for computing vertical dispersion depend highly on the value of longitudinal dispersivity that was used (figs. 49-51). This was noted earlier (figs. 34, 35, 37, and 38). When the longitudinal dispersivity is $400 \mathrm{ft}$, the simulated positions of the 50 percent saltwater concentration lines simulated using different algorithms (fig. 49) differ considerably. When vertical dispersion between layers of different hydraulic conductivity does not occur and vertical dispersion between layers of the same hydraulic conductivity is scaled by a factor of 0.008 , the overall slope of the interface is less than in the other cases, and the slope decreases further in the layers of higher permeability. The lateral extent of the 50-percent saltwater concentration line from land surface to $270 \mathrm{ft}$ below land surface is nearly $10,000 \mathrm{ft}$. When vertical dispersion within groups of adjacent model layers having the same horizontal hydraulic conductivity is not scaled, the higher degree of vertical dispersion causes the interface to be almost vertical within those layer groups, and large changes in the east-west position of the interface occur only where there is a change in hydraulic conductivity (and no vertical dispersion). When the standard algorithms are used and there is no restriction on vertical dispersion anywhere, the interface is nearly vertical and shows no changes of slope at layer boundaries. The lateral extent of the 50-percent saltwater concentration line over the 270 - $\mathrm{ft}$ depth interval is only $1,300 \mathrm{ft}$.

When the longitudinal dispersivity is $40 \mathrm{ft}$, the differences between the interface positions is considerably less (fig. 50). When the longitudinal dispersivity is $4 \mathrm{ft}$, there is almost no difference in the positions of the 50-percent concentration line simulated by the three vertical dispersion algorithms (fig. 5l). The low longitudinal dispersivity causes the degree of vertical dispersion to be small in all three cases. The varying significance of the longitudinal dispersivity value specification is illustrated in figures 52 to 54 . When vertical dispersion only occurs within groups of model layers having the same horizontal hydraulic conductivity and is highly scaled (fig. 52), there is no difference in the position of the 50-percent concentration line when the longitudinal dispersivity is changed from 4 to $40 \mathrm{ft}$. The position of the line shifts seaward only slightly without changing its shape when the longitudinal dispersivity is changed to $400 \mathrm{ft}$. However, when there is no scaling of vertical dispersion within groups of layers having the same horizontal hydraulic conductivity (fig. 53), the slope of the 50-percent saltwater concentration line becomes progressively more vertical within the layer groups as the longitudinal dispersivity increases. The discontinuities in the 50-percent saltwater concentration line at layer interfaces where the hydraulic conductivity changes become progressively larger as the dispersivity value increases. When vertical dispersion is simulated using the standard procedures (fig. 54), the variation in the position of the 50- percent saltwater concentration line and its tendency to show changes in slope at layer boundaries varies greatly as the specified value of longitudinal dispersivity varies. 


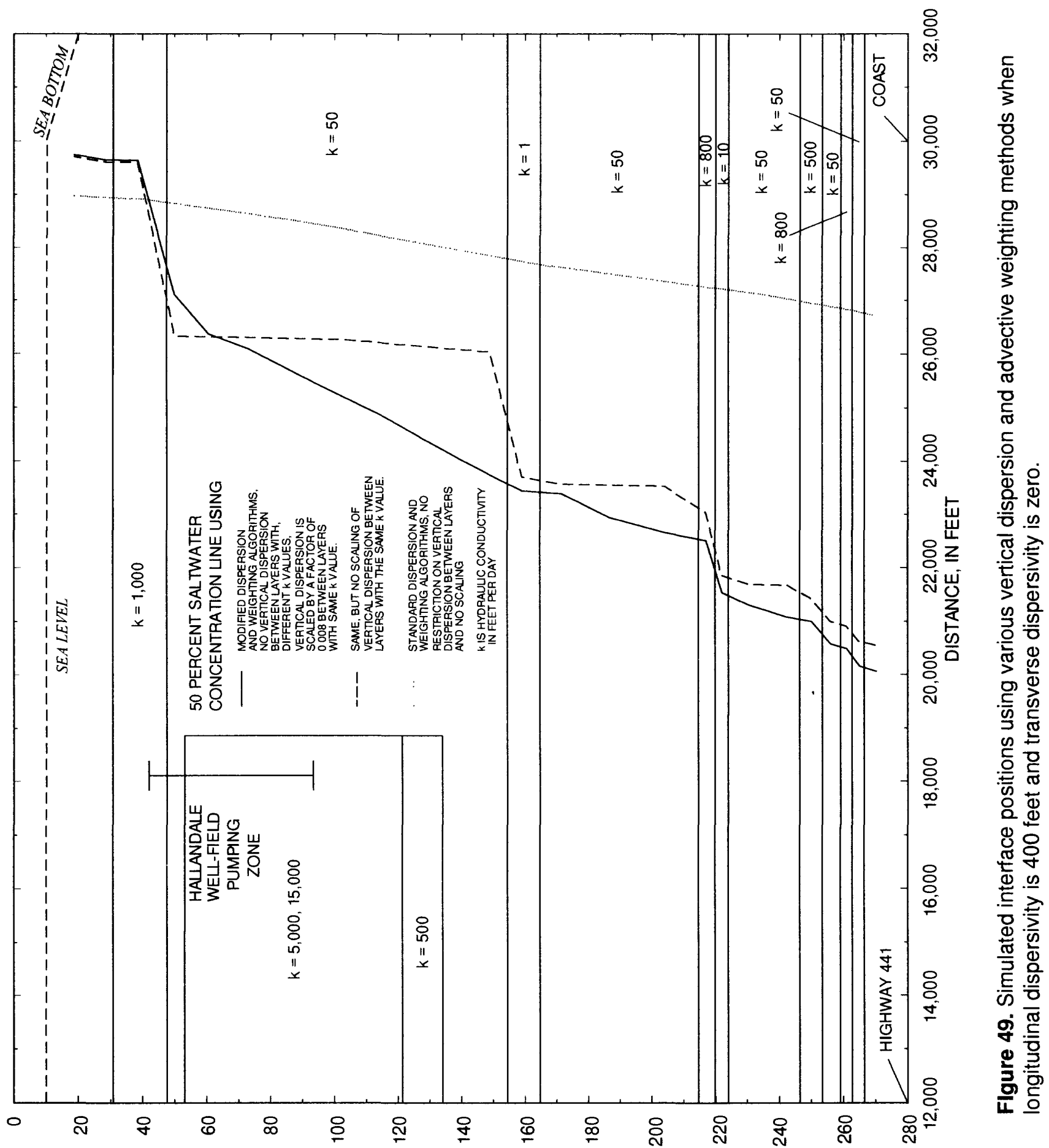

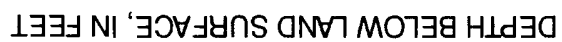




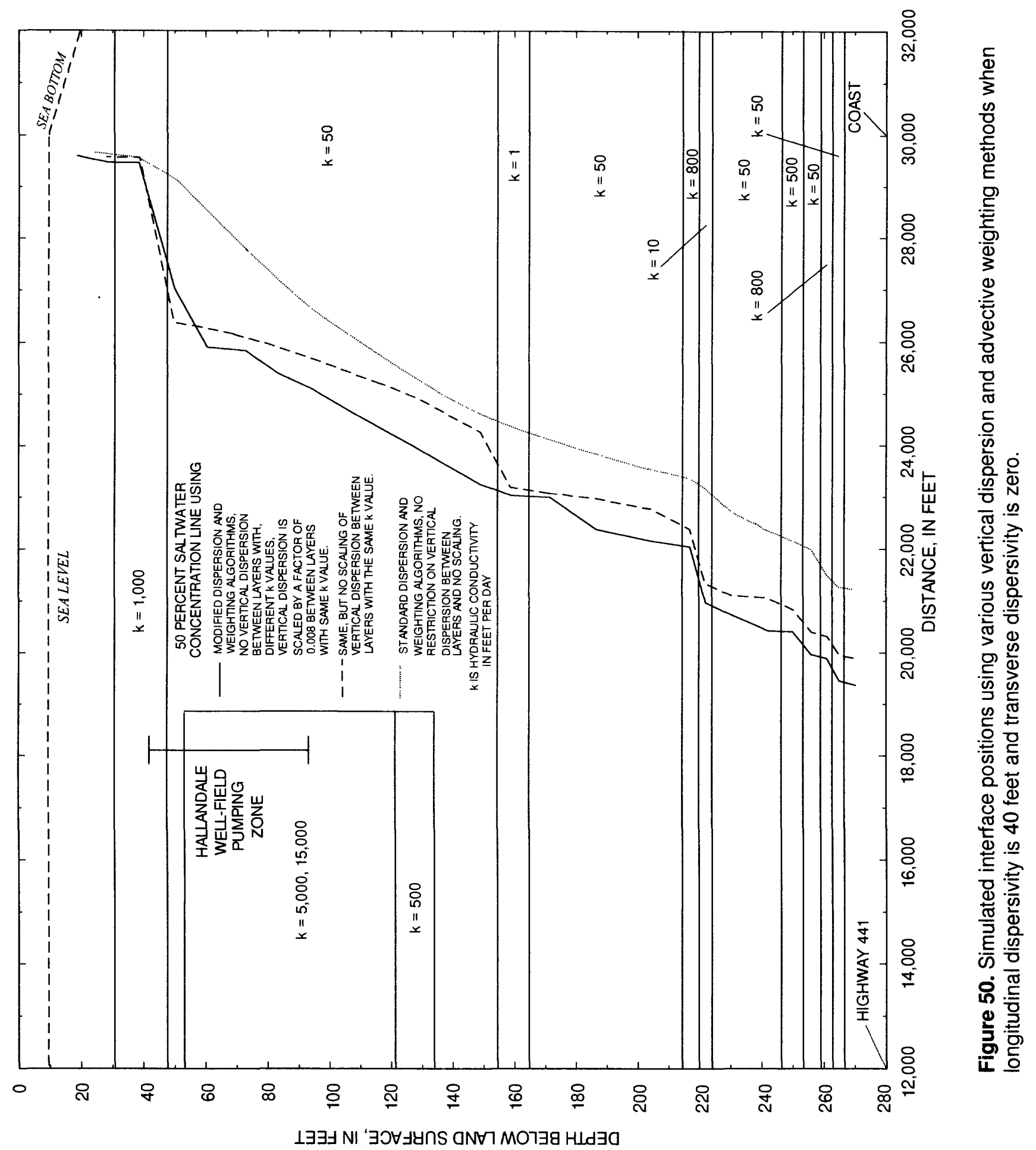




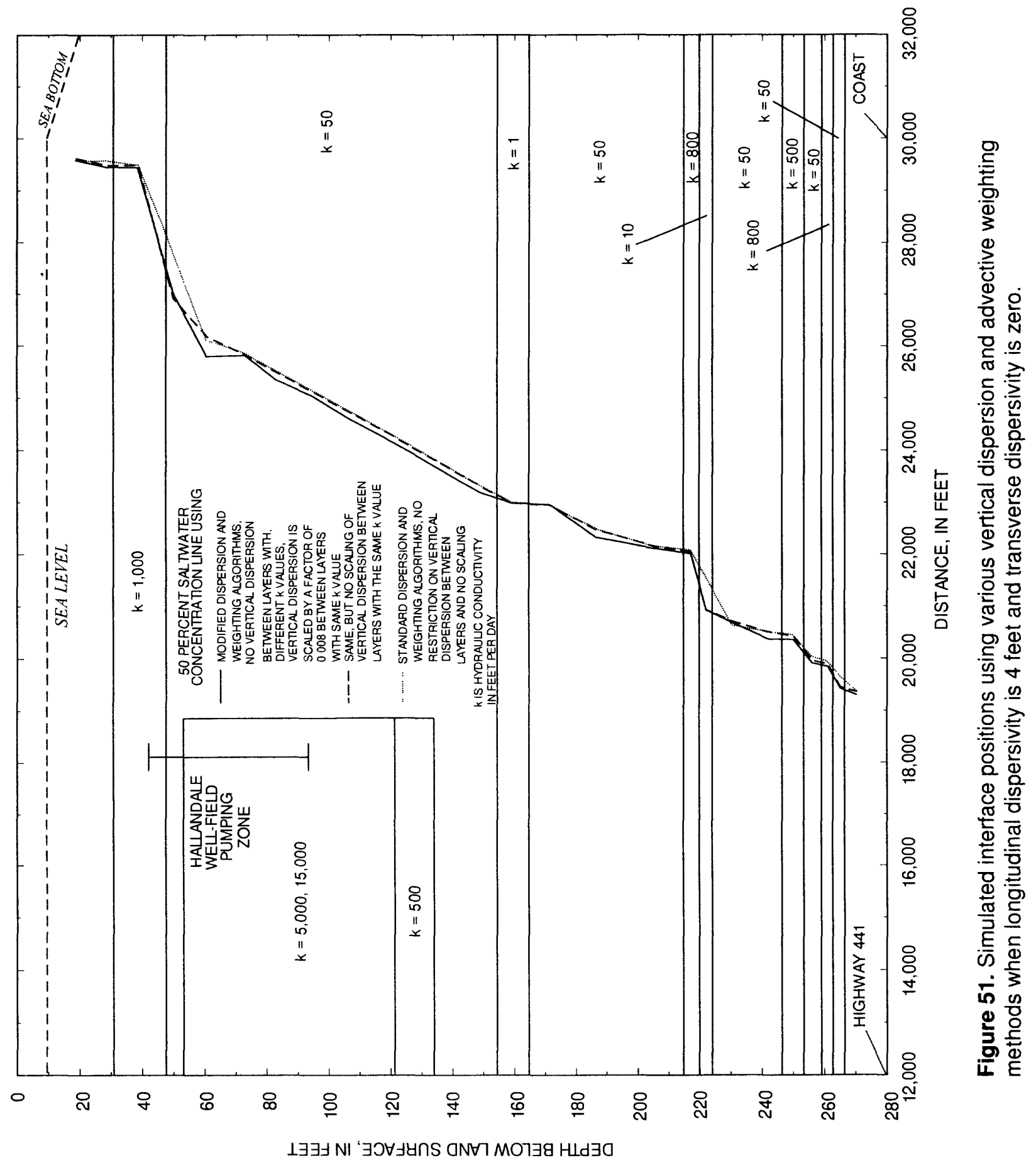




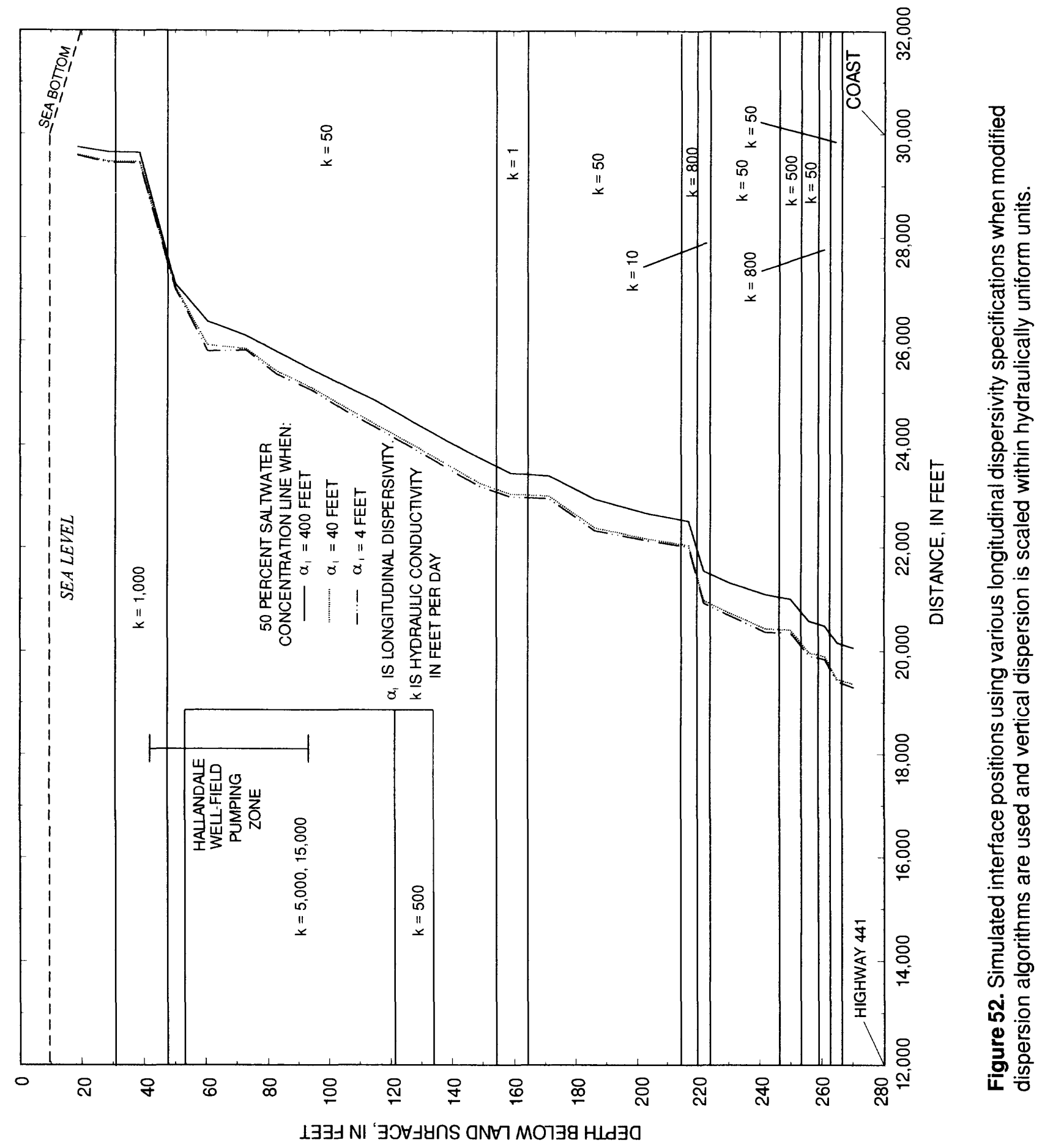




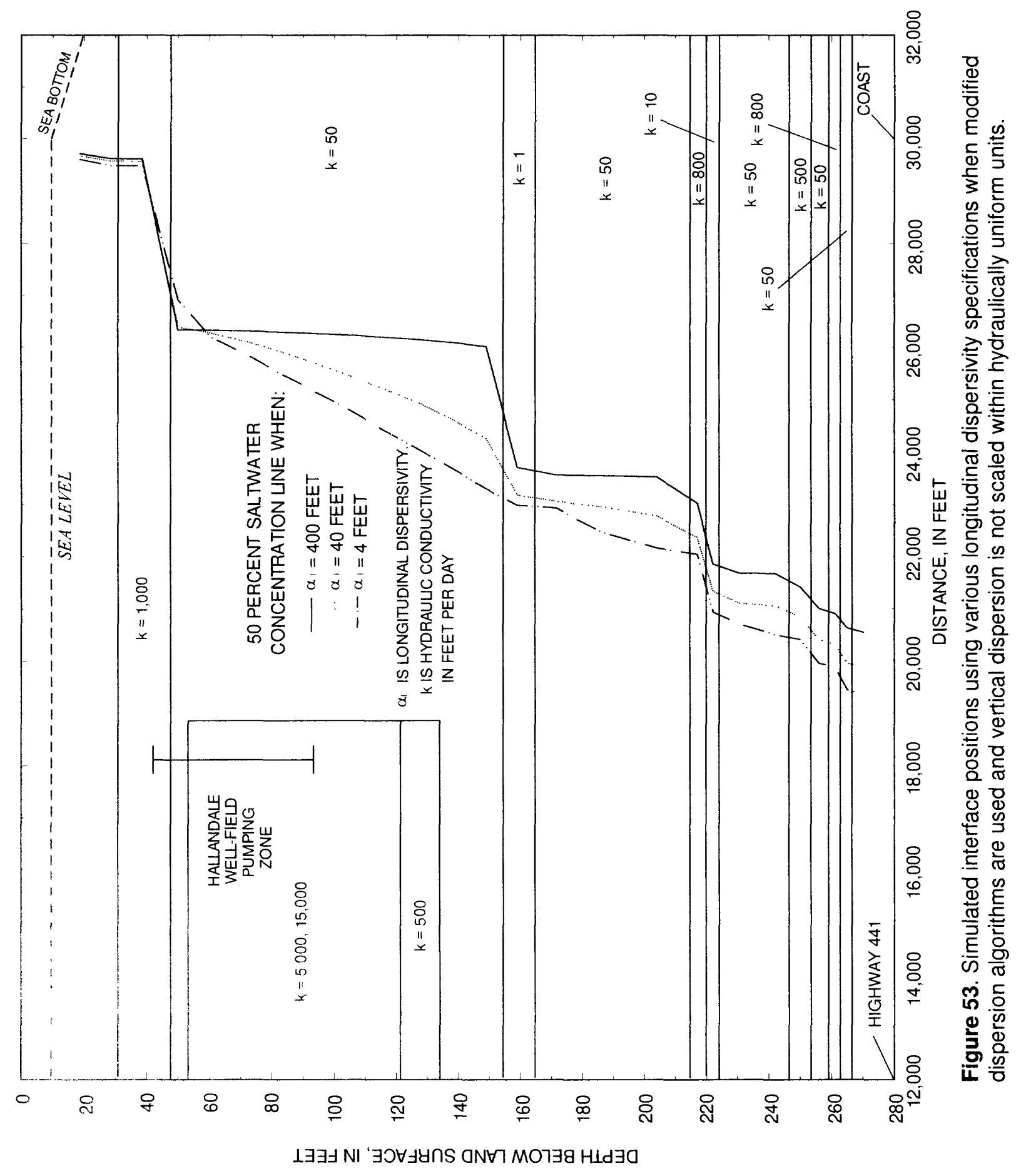




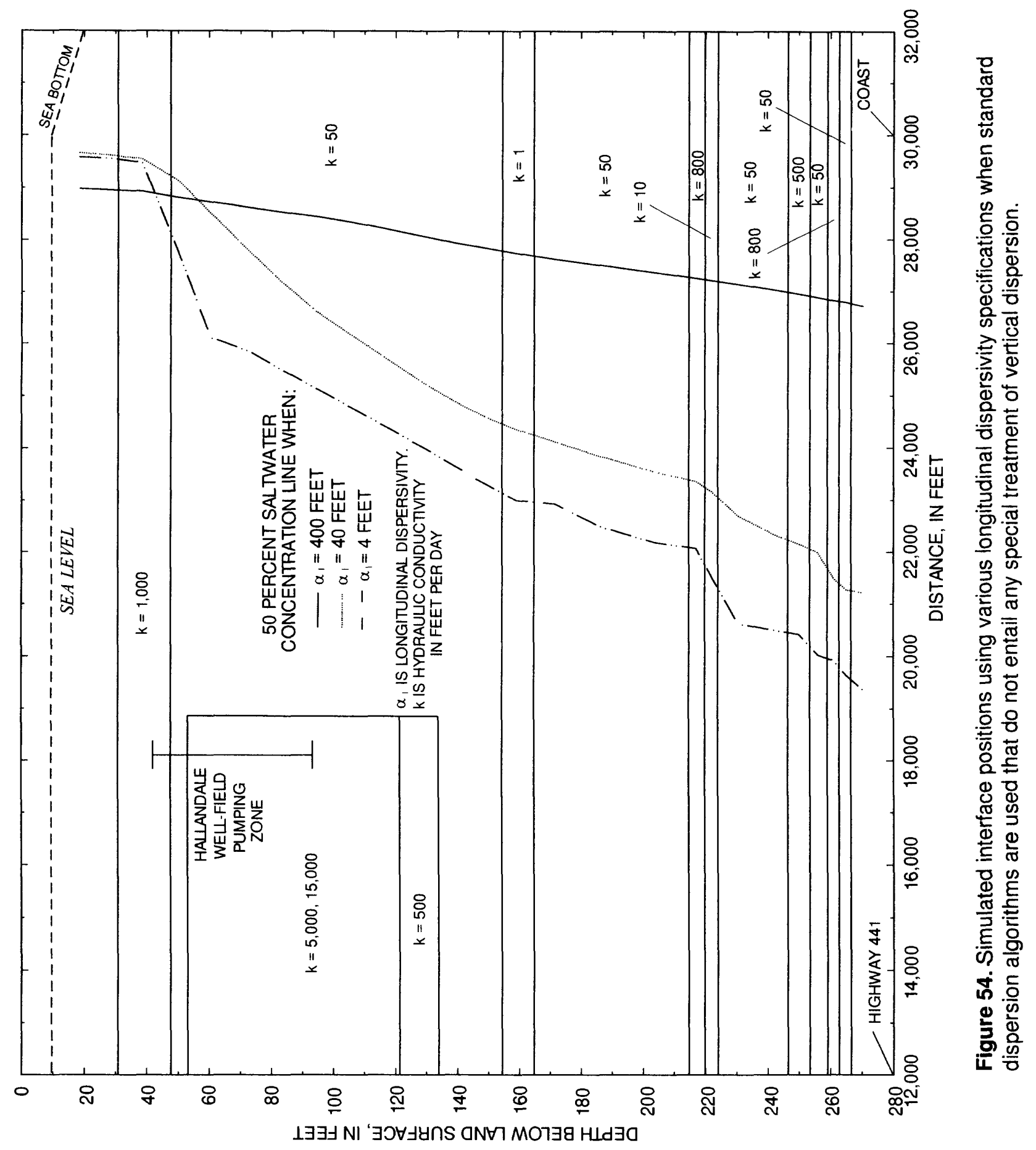


The significance of the three methods of treating vertical dispersion (standard algorithm, modified algorithm with scaling, and modified algorithm with no scaling) needs to be interpreted in physical terms. Use of the standard algorithm assumes that, if a large degree of longitudinal dispersion occurs (a large coefficient value is specified), vertical components of velocity will cause a considerable degree of vertical mixing across all rock layers regardless of their permeability or confining characteristics. Hydraulic conductivity layering would have little influence on the vertical distribution of chloride at equilibrium even though rates of flow in the various hydraulic layers might vary considerably.

When the modified algorithms are used, very litthe dispersive transfer of chloride between layers of contrasting hydraulic conductivity occurs. The only exchanges of chloride simulated at rock interfaces between layers of different hydraulic conductivity are by ionic diffusion or by a slight degree of hydraulically-driven seepage. Even when a high value of longitudinal dispersivity is specified, these exchanges are small in magnitude compared to the degree of dispersion simulated by the standard algorithm, so that large differences in chloride concentration may be simulated at these interfaces.

When using the modified algorithm and a large longitudinal dispersivity coefficient, scaling vertical dispersion allows the simulation of significant vertical gradients in chloride concentration within the hydraulically uniform layers. When vertical dispersion is not scaled, a substantial degree of vertical dispersion within hydraulically uniform layers is simulated and the simulated interface is necessarily almost vertical (no appreciable vertical concentration gradient) within those lave:

Anothes wav of expresing the significanse of the moditice verteal dispersion algorithm relative to the

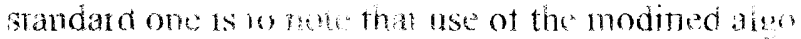
rithms nakes possthe the ilnulation of complex ves

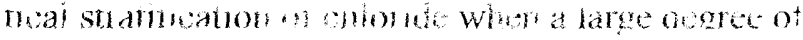
fongluanal distwesion oreus. When the shecticed iongitudinal dis!erswry ss small. the ditiorerice helween alporthm tocrease on magnitud: and the intertaces simulated using all choices of vertical div. persion and weightin:s algorithms have similar 50-percent concentration unes. However, the specitied longitudinal dispersivity still determines the horizontal width. or degree of attenuation. of the transition zone. and a largs value mav be required to realistically simulate a diffuse interface. In addition, simulations using low values of longitudinal dispersivity are sometimes more prone to be affected by oscillatory instability. In the present sensitivity analyses, the physical parameter specifications permitted simulations with a low longitudinal dispersivity value of $4 \mathrm{ft}$ to be performed; in other sets of conditions, it might not be possible to use a low value of longitudinal dispersivity. A basis for a decision about which set of algorithms to use must be guided by the consideration of field data describing the transition zone and the rate of change in chloride concentration at various points in space as the interface moves in response to stresses. The data set of this study generally was not adequate for this purpose.

The transverse dispersivity value was varied by orders of magnitude in the case where longitudinal dispersivity was $400 \mathrm{ft}$ and the modified dispersion algorithm was used with a vertical dispersion scaling factor of 0.008 . Results indicated that a significant effect on the position of the 50-percent concentration line was apparent only when a transverse dispersivity of $100 \mathrm{ft}$ was specified. A transverse dispersivity value of such a magnitude probably does not occur in nature. Recent field studies in a sand and gravel aquifer at Cape Cod, Massachusetts (Garabedian and others, 1991), provided estimates of the ratio of horizontal and vertical components of transverse dispersivity to longitudinal dispersivity of 50:1 and 640:1, respectively. Such tests with an adequate monitoring network are not known to have been conducted in aquifers characterized by a significant degree of secondary permeability. However, generalized simulations of a brackish-water plume in the dissolved-carbonate Biscayne aquifer of Dade County by the author (Merritt, 1996c) indicated that a representative simulation of the plume could be realized by using a transverse dispersivity of $0.1 \mathrm{ft}$ with a longitudinal dispersivity of $250 \mathrm{ft}$. This transverse dispersivity value was essentially zero in its effect on transverse movement of sol. ute in the horizontal plane, but proved to be effectivf" in causing substantial vertical mixing when vertical dispersion in the hydraulically unilorn aquifer wa: not scaled. Horizontal flow predominated and the den sity difference was relatively low $\left(0.15 \mathrm{lb} / \mathrm{ft}^{3}\right)$ com. pared to the difference between freshwater and seawater. These simulations did not establish precise upper or lower limits for longitudinal or transverse dispersivity values that could be considered realistic

There are several general conclusions in this settion, which describe simulations of the saltwater interface position in an aquifer system highly layered with respect to hydraulic conductivity. Simulations converged to nearly the same equilibrium position whether the initial position was an approximate Ghyben-Herzberg line or a vertical interface at the coast. 
Lumping the layers of different hydraulic conductivity did not appreciably change the equilibrium position of the 50-percent saltwater concentration line. Tests of the standard and modified algorithms for vertical dispersion demonstrated that a relatively sharp interface could be simulated in two ways: (1) by the use of the modified algorithm for vertical dispersion and any value of longitudinal dispersivity; and (2) by the use of the standard algorithm for vertical dispersion and a small value of longitudinal dispersivity, if the latter does not cause oscillatory instability. Transverse dispersivity did not seem to be a significant factor in determining the position of the 50-percent saltwater concentration line for values less than an improbably high value of $100 \mathrm{ft}$.

\section{Relation of SWIP Cross-Sectional Analyses to the Simulation of Field Data}

Given the conceptual model of the aquifer that is represented by the specified parameter assignments, the SHARP and SWIP simulations of the predevelopment position of the saltwater interface in southern coastal Broward County are in general agreement with each other when algorithms and parameters used in SWIP lead to the simulation of a relatively sharp interface. Unfortunately, neither simulation has provided a representative portrayal of the conditions actually measured because the actual interface position, years after drainage works were placed in use and after wellfield pumping began, is below and seaward of the predevelopment interface position portrayed by these simulations. The model tests and sensitivity analyses using SWIP have been useful, however, in showing which parameter values are of greatest significance in determining the position of the interface, given a classical conceptual model of freshwater flow toward a coastal location of discharge to tidewater. It has been shown that the spatial distribution of hydraulic conductivity is of considerable significance. Also important is the choice of method for representing the process of vertical dispersion together with the related magnitude of longitudinal dispersivity.

Because unidirectional flow toward the coast is a generalization of the true conditions existing in the aquifer in the study area, the simulation of field data was considered to require the construction of a moredetailed three-dimensional model that could represent three-dimensional variations in hydraulic characteristics, boundary conditions, and hydraulic stresses. Although a discussion of unsuccessful attempts to simulate the field data with a three-dimensional model is beyond the scope of this report, certain preliminary findings from this effort are pertinent to the present discussion. These findings are as follows:
- After minor revisions to the 20-layer cross-sectional grid (fig. 39), the SWIP model grid was extended north and south in 11 slices $\left(n_{y}=11\right)$ to form a three-dimensional grid. The grid included a thin row and a thin column to represent Hollywood and Spur Canals in the upper layer. This model required considerably more computer processing time than the already lengthy times needed for running the cross-sectional models.

- Considerable difficulty was experienced in specifying pressures along the northern and southern boundaries that transected the saltwater interface. Use of freshwater densities to specify boundary pressures in the saltwater zone near the coast led to massive fluxes of saltwater across the northeastern and southeastern corners of the grid.

- An attempt was made to resolve the boundary specification problem by assigning boundary pressure values during the simulation that were the same as those in the grid cells adjacent to the boundary. However, small areal head gradients still caused large saltwater-zone fluxes. The only simulations without this difficulty were those with a no-flow boundary specification, except for the top layer in cases where canal heads were used as boundary conditions.

- Preliminary results from the three-dimensional model simulations did not differ appreciably from results provided by the cross-sectional model, an expected result because the choice of no-flow conditions on the northern and southern boundaries forced the portrayal of an eastwest flow system similar to the one assumed as a basis for the cross-sectional simulation of preequilibrium conditions. In particular, discrepancies between simulated heads and concentrations and measured heads and the depth to saltwater in the Hallandale Well Field were not resolved by a three-dimensional approach that was still based on the assumption of eastward flow to a coastal discharge location.

It seems that substantial revisions to the conceptual model of the aquifer flow system will be needed, and direct evidence of the location of freshwater discharges to tidewater would be helpful. In northern Dade County, substantial predevelopment freshwater discharges just onshore and as submarine springs offshore were documented by Parker and others (1955), and evidence of present-day discharge in reduced quantity was documented by Kohout (1967) and Kohout and Kolipinski (1967). Direct evidence of freshwater discharge in other sections of the Atlantic Coast of Florida, however, is largely lacking.

In Palm Beach County, a highly permeable aquifer near the Atlantic Coast is bounded on the east and west by stratigraphically similar materials lacking solution porosity, and therefore, substantially less permeable than rocks of the aquifer (Swayze and Miller, 1984). In some sections of the coast, the facies change is very near the present-day shoreline. This suggests 
that a substantial or even dominant component of ground-water flow might be parallel to the coastline and not toward tidewater in some sections of the coast of Palm Beach County. It is possible that similar or analogous conditions might also exist in parts of Broward County. Further data collection and conceptual model development might help to resolve apparent discrepancies between the relation of the saltwater interface position and the water-table altitude predicted by theory and the actual relation indicated by field data.

\section{SUMMARY}

In southeastern Florida, the most severe effects of saltwater intrusion have been experienced in Broward and Dade Counties. The severity of the problem in Broward County is largely related to geography. Most early settlement occurred on a narrow coastal strip of land not more than $5 \mathrm{mi}$ wide, the "coastal ridge," where land elevations reach $20 \mathrm{ft}$ above sea level. Most well fields were constructed near the population centers of the coastal ridge. The construction of major regional drainage canals, three of which transect Broward County, caused a lowering of the water table that facilitated the gradual inland movement of the saltwater front toward the well fields.

The construction of long tidal canals extending inland from or paralleling the coast to provide ocean access to boat owners has further lowered the water table and has allowed saltwater to enter the aquifer as direct seepage from canals in inland areas. In recent years, pumping has had to be curtailed at most wells used for supply by the Cities of Hallandale and Dania. Water managers are concerned about the future availability of water supply from well fields used by the Cities of Deerfield Beach, Pompano Beach, Fort Lauderdale, and Hollywood. One of the well fields owned by Broward County is threatened with saltwater intrusion from a tidal canal and requires monitoring with a network of wells.

Southeastern Broward County is an area of generally flat terrain. The annual average rainfall in Fort Lauderdale from 1914 to 1992 was 61.76 in., of which 71 percent fell during the months of May through October. Evapotranspiration rates in the study area are high and tend to vary with the amount of solar radiation, which implies a strongly seasonal variation (higher in summer, lower in winter). Based on an analogy with stage and water-table altitude records from stations in similar or analogous surface soil environments in Dade County, it is surmised that the average predevelopment water table in the vicinity of Highway 441 in southeastern Broward County was as much as $2.5 \mathrm{ft}$ higher than present-day (1994) average heads.

The highly permeable Biscayne aquifer occurs at about 35 to $50 \mathrm{ft}$ below land surface in southeastern Broward County (the study area). The transmissivity of the Biscayne aquifer has been estimated to be greater than $1,000,000 \mathrm{ft}^{2} / \mathrm{d}$ east of Highway I-95, where sections of the highly permeable Key Largo Limestone are present. The average hydraulic conductivity of the Biscayne aquifer in the study area is probably between 7,500 and $10,000 \mathrm{ft} / \mathrm{d}$.

Most of the present water-management system was completed by the late 1960 's, with the construction of the many control structures, including culverts with risers and stop logs, gated culverts, gated spillways, and pump stations. Generally, the effect of the north-south levee and the various controls was to significantly decrease the amount of seasonal variation in well water levels. Wet-season average highs from September to November were reduced and water levels between March and July were increased.

The field investigation of saltwater intrusion in the Biscayne aquifer of southeastern Broward County by the USGS began in 1939 and is divided into two distinct time periods. The early period of data collection generally ended in 1944-45. The operation of a network of observation wells began in the autumn of 1967 , and new wells have been added to the network throughout the 1970's, 1980's, and early 1990's. Most wells that monitor chloride are located in the vicinity of well fields because of the critical importance of the potential effect of saltwater intrusion on public-water supply. In the study area, well fields with observation well networks include the Hollywood Well Field, Hallandale Well Field, and Broward County Utilities Well Field 3A.

The chloride concentrations of water samples collected between 1939 to 1994 from various monitoring and exploratory wells were used to delineate the approximate position of the saltwater front in 1945 , 1969, and 1993. Results indicated that the front has moved as much as $0.5 \mathrm{mi}$ inland in parts of the study area. Water samples from the large number of monitoring wells east (seaward) of the Hallandale Well Field show a clear pattern of saltwater intrusion toward the pumping wells since the first wells were drilled in 1969. In 1988, pumping from the main part of the well field was curtailed. Water samples from many of the wells of the Hollywood Well Field monitoring network were high in chloride concentration, 
but no trends were evident over a 20 -year period, suggesting that the presence of chloride might be caused by seasonal increases in the chloride concentration of water in the tidal Hollywood Canal.

The numerical simulation of the saltwater intrusion process was considered highly useful because such techniques have the potential to: (1) help determine which of the various hydrologic properties and water-management practices characterizing the coastal subsurface environment and its use by man is dominant or significant in causing saltwater intrusion to occur, and (2) provide a simulator that would show what effect changes in system management could have on the saltwater intrusion process. Two model codes were applied in the course of the study. These codes are the SHARP code, which simulates the position of the saltwater front as a sharp interface without any transition zone (a zone in which a gradational change between fresh and saltwater mineralization occurs), and the SWIP code, which simulates a two-fluid variable-density system with a convective-diffusion approach that contains a representation of the transition zone.

The SHARP code was used for estimates of the likely interface position under predevelopment conditions and under recent conditions as affected by watermanagement control and as affected by the Hallandale Well Field. In order to estimate the location of the predevelopment interface, it was assumed that natural flow was uniformly in the eastward direction throughout the area modeled. The annual average head along the western boundary (at the present location of Highway 441) was considered to be $5 \mathrm{ft}$ above sea level. The hydraulic conductivity of the aquifer was estimated to be $10,000 \mathrm{ft} / \mathrm{d}$. The predevelopment sharp interface was simulated as being located below the main well-field pumping zone at about $127 \mathrm{ft}$, which is inconsistent with the observation that water samples from a test hole drilled in the center of the well field in 1981 were fresh to $300 \mathrm{ft}$ after decades of water management and well-field pumping. The simulation results were insensitive to a major change in the bottom slope of the aquifer, or to a uniform 25-percent reduction in the hydraulic conductivity value, and only moderately sensitive to a 150 -percent increase in net atmospheric recharge.

Because the SHARP predevelopment simulation constrained flow to be uniform in the easterly direction, an analogous simulation could be devised using a cross-sectional application of the SWIP code for a comparison of the sharp interface and diffuse interface methods and for an assessment of the effect of dispersion on the equilibrium position of the interface.
Boundaries of the 11-layer cross section corresponded to the east and west boundaries of the SHARP grid; aquifer thickness, ocean bottom depths, and aquifer properties were described similarly. Simulation time periods ranged from 40 to 400 years. All lines of equal concentration within the transition zone converged to an equilibrium position.

The 50-percent saltwater concentration line of the diffuse interface simulated by SWIP converged to a position similar to the interface position simulated by SHARP when a low value of longitudinal dispersivity was specified or when modified dispersion algorithms were used that greatly reduced the degree of simulated vertical dispersion. When a high longitudinal dispersivity value was used together with the standard dispersion algorithms, a broad, diffuse, and nearly vertical transition zone was simulated, and the 50 -percent saltwater concentration line was located thousands of feet seaward of the position simulated by SHARP. The simulated transition zone was much narrower when a longitudinal dispersivity value of $40 \mathrm{ft}$ was specified than when a value of $400 \mathrm{ft}$ was specified, regardless of the dispersion algorithm used. The position and degree of dispersal of the transition zone were insensitive to moderate variations of the low transverse dispersivity value.

A 20-layer cross-sectional grid, in which layers had uniform thickness, was designed for additional analyses with SWIP. Parts of layers of the grid were specified as having lower permeability than the principal part of the Biscayne aquifer to represent the lower permeability of the overlying leaky sand layer and inland sections of the underlying Tamiami and Hawthorn Formations. The simulated equilibrium position of the 50-percent saltwater concentration line was somewhat sensitive to variations in the spatial distribution of permeability. The position of the 50-percent saltwater concentration line was not appreciably sensitive to the specification of seasonally varying boundary conditions and net recharge rate or to a physically realistic degree of variation in the density of saltwater.

Another cross-sectional grid with 28 layers and hypothetical stresses (arbitrary specifications for boundary heads, rainfall, and evapotranspiration rates) was used for additional sensitivity analyses with SWIP. Treating thin layers of widely contrasting hydraulic conductivity as one or several layers with thickness-weighted average hydraulic conductivities did not appreciably change the simulated equilibrium position of the 50-percent concentration line. When the layers were explicitly represented, the interface 
tended to be more horizontal in layers of high hydraulic conductivity and more vertical in layers of lower hydraulic conductivity. Other tests with the 28-layer model demonstrated the strong sensitivity of the position and dispersal of the simulated transition zone to the choice among optional algorithms for computing vertical dispersion and to the related choice of longitudinal dispersivity value.

A study of velocities simulated by the 20-layer model indicates a saltwater convection cell that extends seaward in the aquifer from the offshore freshwater discharge location. A slight degree of inland convection of saltwater occurs beneath land. Freshwater discharge was upward through the leaky sand layer at the shoreline rather than at the presumed outcrop of the aquifer at the edge of the shelf when the leaky sand layer was assigned a hydraulic conductivity value of $250 \mathrm{ft} / \mathrm{d}$ everywhere. When the layer was assigned a hydraulic conductivity value of $0.05 \mathrm{ft} / \mathrm{d}$ offshore, discharge was at the outcrop location, but the simulated inland extent of the saltwater zone was similar to that previously simulated.
In all cross-sectional simulations, the equilibrium interface position approximately coincided with the interface position that would be estimated using the Ghyben-Herzberg relation and simulated equilibrium head values, and a near-equilibrium position was established in zones of high hydraulic conductivity within one to several years. In contrast, the average head measured near the Hallandale Well Field since 1970 was less than half the values simulated in various cross-sectional model runs. When preequilibrium conditions were simulated, the head at the well field quickly rose to a value higher than the equilibrium value, and then decreased gradually as the equilibrium position of the interface was established. The simulations, therefore, failed to demonstrate that the low measured heads were a preequilibrium condition. The results of the cross-sectional simulations suggest that the conceptual model of freshwater flow eastward to offshore locations of discharge to tidewater might need some revision. 


\section{REFERENCES CITED}

Alvarez, J.A., and Bacon, D.D., 1988, Production zones of major public water supply well fields for the counties in the South Florida Water Management District: South Florida Water Management District Technical Publication no. 88-4.

Anderson, P.F., Mercer, J.W., and White, H.O., Jr., 1988, Numerical modeling of saltwater intrusion at Hallandale, Florida: Ground Water, v. 26, no. 5, p. 619-633.

Appel, C.A., 1973, Electrical-analog model study of a hydrologic system in southeast Florida: U.S. Geological Survey Open-File Report FL-73004, 51 p.

Badon-Ghyben, W., 1889, Nota in verband met de voorgenomen put boring nabij Amsterdame (Notes on the probable results of the proposed well drilling near Amsterdam): K. Inst. Ing. Tijdschr., The Hague, p. 21.

Bear, J., 1972, Dynamics of fluids in porous media: New York, American Elsevier Publishing Company, 764 p.

---- 1979, Hydraulics of groundwater: New York, McGraw-Hill, 569 p.

Bear, J., and Dagan, G., 1964, Moving interface in coastal aquifers: Journal of Hydraulics Division, Proceedings of American Society of Civil Engineering, 90 (HY4), p. 193-216.

Bearden, H.W., 1972, Ground water in the Hallandale area, Florida: Florida Bureau of Geology Information Circular no. $77,32 \mathrm{p}$.

---- 1974, Ground-water resources of the Hollywood area, Florida: Florida Bureau of Geology Report of Investigation no. $77,35 \mathrm{p}$.

Beaven, T.R., 1979, Hydrologic conditions in Broward County, Florida, 1976: U.S. Geological Survcy OpenFile Report 79-1258, 93 p.

Brooks, I.H., and Niiler, P.P., 1977, Energetics of the Florida current: Journal of Marine Research, v. 35, no. 1, p. 163-191.

Causaras, C.R., 1985, Geology of the surficial aquifer system, Broward County, Florida: U.S. Geological Survey Water-Resources Investigations Report 84-4068, 167 p., 2 sheets.

Cooper, H.H., Jr., 1959, A hypothesis concerning the dynamic balance of freshwater and saltwater in a coastal aquifer: Journal of Geophysical Research, v. 64, no. 4, p. 461-467.

Cooper, H.H., Kohout, F.A., Henry, H.R., and Glover, R.E., 1964, Sea water in coastal aquifers: U.S. Geological Survey Water-Supply Paper 1613-C, 84 p.

Essaid, H.I., 1990, The computer model SHARP, a quasithree-dimensional finite-difference model to simulate freshwater and saltwater flow in layered coastal aquifer systems: U.S. Geological Survey Water-Resources Investigations Report 90-4130, $181 \mathrm{p}$.
Fish, J.E., 1988, Hydrogeology, aquifer characteristics, and ground-water flow of the surficial aquifer system, Broward County, Florida: U.S. Geological Survey WaterResources Investigations Report 87-4034. 92 p., 10 pls.

Fish, J.E., and Stewart, Mark, 1991, Hydrogeology of the surficial aquifer system, Dade County, Florida: U.S. Geological Survey Water-Resources Investigations Report 90-4108, 50 p., 11 pls.

Garabedian, S.P., LeBlanc, D.R., Gelhar, L.W., and Celia, M.A., 1991, Large-scale gradient tracer test in sand and gravel, Cape Cod, Massachusetts, 2, Analysis of spatial moments for a nonreactive tracer: Water Resources Research, v. 27, no. 5, p. 911-924.

Gelhar, L.W., Welty, Claire, and Rehfeldt, K.R., 1992, A critical review of data on field-scale dispersion in aquifers: Water Resources Research, v. 28, no. 7, p. 1955-1974.

Grantham, R.G., and Sherwood, C.B., 1968, Chemical quality of waters of Broward County, Florida: Florida Division of Geology Report of Investigations no. 51, $52 \mathrm{p}$.

Herzberg, Alexander, 1901, Die Wasserversorgung einiger Nordseebader (The water supply on parts of the North Sea Coast): Munich, Jour. Gasbeleucht Verw. Beleachtungsarten Wasserversorg, v. 44, p. 815-819, 842-844.

Howie, Barbara, 1987, Chemical characteristics of water in the surficial aquifer, Broward County, Florida: U.S. Geological Survey Water-Resources Investigations Report 86-4330, 2 sheets.

Hubbert, M.K., 1940, The theory of ground-water motion: Journal of Geology, v. 48, no. 8, pt. 1, p. 785-944.

INTERA Environmental Consultants, Inc., 1979, Revision of the documentation for a model for calculating effects of liquid waste disposal in deep saline aquifers: U.S. Geological Survey Water-Resources Investigations Report 79-96, $73 \mathrm{p}$.

INTERCOMP Resource Development and Engineering, Inc., 1976, A model for calculating effects of liquid waste disposal in deep saline aquifers, parts 1 and 2: U.S. Geological Survey Water-Resources Investigations Report 76-61, $253 \mathrm{p}$.

Kipp, K.L., Jr., 1987, HST3D: A computer code for the simulation of heat and solute transport in three-dimensional ground-water flow systems: U.S. Geological Survey Water-Resources Investigations Report 864095, $517 \mathrm{p}$.

Klein, Howard, and Waller, B.G., 1985, Synopsis of saltwater intrusion in Dade County, Florida, through 1984: U.S. Geological Survey Water-Resources Investigations Report 85-4101, 1 sheet.

Kohout, F.A., 1960, Cyclic flow of salt water in the Biscayne aquifer of southeastern Florida: Journal of Geophysical Research, v. 65, no. 7, p. 2133-2141. 
-.--- 1967, Relation of seaward and landward flow of ground water to the salinity of Biscayne Bay at Miami, Florida: U.S. Geological Survey Open-File Report FL-67012, $98 \mathrm{p}$.

Kohout, F.A., and Klein, Howard, 1967, Effect of pulse recharge on the zone of diffusion in the Biscayne aquifer: International Symposium on Artificial Recharge of Aquifers and Related Problems, Haifa, Israel, March 19-26, 1967, International Association of Scientific Hydrology Publication no. 70, p. 252-270.

Kohout, F.A., and Kolipinski, M.C., 1967, Biological zonation related to groundwater discharge along the shore of Biscayne Bay, Miami, Florida: Estuaries, American Association for the Advancement of Science, p. 488-499.

Kohout, F.A., and Leach, S.D., 1964, Salt-water movement caused by control-dam operation in the Snake Creek Canal, Miami, Florida: Florida Geological Survey Report of Investigations no. 24, part 4, 49 p.

Lantz, R.B., 1971, Quantitative evaluation of numerical diffusion (truncation error): Society of Petroleum Engineers Journal, September 1971, p. 315-320.

Lee, C.H., and Cheng, R.T.-Sh., 1974, On seawater encroachment in coastal aquifers: Water Resources Research, v. 10, no. 5, p. 1039-1043.

MacVicar, T.K., 1983, Rainfall averages and selected extremes for central and southern Florida: South Florida Water Management District Technical Publication 83-2, $31 \mathrm{p}$.

Mercer, J.W., Larson, S.P., and Faust, C.R., 1980, Finite-difference model to simulate the areal flow of saltwater and freshwater separated by an interface: U.S. Geological Survey Open-File Report 80-407, 88 p.

Merritt, M.L., 1993, Aspects of numerical and representational methods related to the finite-difference simulation of advective and dispersive transport of freshwater in a thin brackish aquifer: Journal of Hydrology, v. 148, p. 61-92.

----- 1996a, Tests of subsurface storage of freshwater at Hialeah, Dade County, Florida, and numerical simulation of the salinity of recovered water: U.S. Geological Water-Supply Paper 2431 (in press).

$1996 \mathrm{~b}$, Simulation of the water-table altitude in the Biscayne aquifer, southern Dade County, Florida, water years 1945-89: U.S. Geological Survey WaterSupply Paper 2458 (in press).

---- 1996c, Numerical simulation of a plume of brackish water in the Biscayne aquifer originating from a flowing artesian well, Dade County, Florida: U.S. Geological Survey Water-Supply Paper 2464, 74 p.

Parker, G.G., Ferguson, G.E., Love, S.K., and others, 1955, Water resources of southeastern Florida: U.S. Geological Survey Water-Supply Paper 1255, 965 p.
Pendleton, R.F., Dollar, H.D., Law, Lloyd, Jr., and others, 1984, Soil survey of Broward County, Florida - eastern part: U.S. Department of Agriculture, Soil Conservation Service.

Pinder, G.F., and Cooper, H.H., 1970, A numerical technique for calculating the transient position of the saltwater front: Water Resources Research, v. 6, no. 3, p. 875-882.

Pitt, W.A.J., Jr., 1977, Summary of project activities for BCUD System \#3 (Playland Isles): U.S. Geological Survey Administrative Report to Broward County Utilities Department.

Price, H.S., Varga. R.S., and Warren, J.E., 1966, Application of oscillation matrices to diffusion-convection equations: Journal of Mathematics and Physics, v. 45, p. 301-311.

Reilly, T.E., and Goodman, A.S., 1985, Quantitative analysis of saltwater-freshwater relationships in groundwater systems-a historical perspective: Journal of Hydrology, v. 80, p. 125-160.

Scheidegger, A.E., 1961, General theory of dispersion in porous media: Journal of Geophysical Research, v. 66, no. 10 , p. $3273-3278$.

Segol, Genevieve, and Pinder, G.F., 1976, Transient simulation of saltwater intrusion in southeastern Florida: Water Resources Research, v. 12, no. 1, p. 65-70.

Segol, Genevieve, Pinder, G.F., and Gray, W.G., 1975, A Galerkin-finite element technique for calculating the transient position of the saltwater front: Water Resources Research, v. 11, no. 2, p. 343-347.

Sherwood, C.B., 1959, Ground-water resources of the Oakland Park area of castern Broward County, Florida: Florida Geological Survey Report of Investigations no. $20,40 \mathrm{p}$.

Sherwood, C.B., McCoy, H.J., and Galliher, C.F., 1973, Water resources of Broward County, Florida: Florida Bureau of Geology Report of Investigations no. 65, $141 \mathrm{p}$.

Sonenshein, R.S., 1992, Documentation of a digital spatial data base for hydrologic investigations, Broward County, Florida: U.S. Geological Survey WaterResources Investigations Report 92-4061, 55 p.

Stephens, J.C., and Stewart, E.H., 1963, A comparison of procedures for computing evaporation and evapotranspiration: Publication No. 62 of 1ASH Commission for Evaporation, Transaction of IUGG, Florida Agricultural Experiment Station Journal Series no. 1664, p. 123-133.

Stewart, E.H., and Mills, W.C., 1967, Effect of depth to water table and plant density on evapotranspiration rate in southern Florida: Transactions of the American Society of Agricultural Engineers, v. 10, no. 6, p. 746-747. 
Swayze, L.J., and Miller, W.L., 1984, Hydrogeology of a zone of secondary permeability in the surficial aquifer of eastern Palm Beach County, Florida: U.S. Geological Survey Water-Resources Investigations Report $83-4249,39 \mathrm{p}$.

Tarver, G.R., 1964, Hydrology of the Biscayne aquifer in the Pompano Beach area, Broward County, Florida: Florida Geological Survey Report of Investigations no. $36,67 \mathrm{p}$.

Todd, D.K., 1980, Groundwater hydrology: New York, John Wiley and Sons, 2nd ed., 535 p.
Trescott, P.C., Pinder, G.F., and Larson, S.P., 1976, Finite difference model for aquifer simulation in two dimensions with results of numerical experiments: U.S. Geological Survey Techniques of Water-Resources Investigations, book 7, chap. $\mathrm{C} 1,116 \mathrm{p}$.

U.S. Environmental Protection Agency, 1977, Quality criteria for water, 1976: $256 \mathrm{p}$.

Vorhis, R.C., 1948, Geology and ground water of the Fort Lauderdale area: Florida Geological Survey Report of Investigations no. $6,43 \mathrm{p}$. 


\section{APPENDIX 1}

Lithologic Description of Core Samples Acquired from Test Holes G-2610 and G-3472 


\section{Test Hole G-2610}

[Descriptions by Joseph F. Whitley, U.S. Geological Survey, Miami]

U.S. Geological Survey identification number: 260200080071601

U.S. Geological Survey local number: G-2610

U.S. Geological Survey project identification number: BRS-1

Location: West Lake Park, about 500 feet south of Sheridan Street between the Westlake and Intracoastal

Waterway bridges. Access was by an unimproved road behind a gate at Sheridan Street.

Date cored: September to November 1989; two holes were drilled - the first to 56 feet and the second to 273 feet - and both were filled in afterward.

Depth

(feet)

Description of sample

0-3 Fill.

3-9 Freshwater micrite, pink to black; allochems; thin pelecypod shell fragments less than 5 percent, fine sand size, angular to subangular; terrigenous grains (quartz), 1 percent, found only inside burrows, fine to medium sand size, angular to subrounded; micrite cement, intergranular porosity less than 5 percent, low bulk rock porosity, branching sedimentary structures (burrows); subaerial horizon at 6 to 9 feet.

9-10 Freshwater micrite, pink to brown; allochems; ostracods 5 percent, gastropods 2 percent, pelecypods 1 percent, fine sand size, subangular to subrounded; no terrigenous grains, intergranular porosity less than 5 percent, low bulk rock porosity, mottled micrite equals bioturbation.

10-20 No recovery.

20-37 Unlithified sand 50 percent quartz, 50 percent carbonate skeletal material (fine to coarse sand near top and coarsening down toward the bottom to pebble size), mollusk shells both whole and in fragments, concretions 5 millimeters to 3 centimeters, ooids less than 1 percent.

37-40 Calcareous sandstone, white to tan; allochems; algae 20 percent, foraminifera 2 percent, rounded to subrounded, fine to medium sand (star coral fragment 3 to 4 centimeters); terrigenous grains; quartz and feldspar, 40 percent; intergranular micrite cement, in places micrite is being recrystallized to sparite; intergranular porosity 10 percent, medium bulk rock porosity.

40-42 Sandy biosparite, calcarenite, orange to yellow; allochems; pelecypod and gastropod shell fragments; terrigenous grains; about 10 percent quartz, high bulk rock porosity (coquina with concretions).

42-55 Sandy biosparite, white to tan; allochems; pelecypod 50 percent, foraminifera 2 percent, algae less than 2 percent, medium sand to gravel size, angular to subrounded; terrigenous grains; quartz, feldspar, calcite, 10 percent, fine to coarse sand, subangular to subrounded; coquinoid limestone with much recrystallization, intergranular porosity 10 to 20 percent, high to very high bulk rock porosity, high angle bedding; possible subaerial horizon at 47 to 50 feet. 
Depth

55-62 Sandy biosparite, medium to coarse calcarenite, gray to orange; allochems; mollusk shells, foraminifera and algae, high bulk porosity with vugs; possible subaerial horizon at 55 to 60 feet.

62-65 Sandy biosparite, medium to coarse calcarenite, white to tan; allochems; mollusk shells, foraminifera and algae, medium bulk rock porosity; possible subaerial horizon at 63 to 65 feet.

65-67 Top of section is the same as 63 to 65 feet, grading down to fine calcarudite, medium to high bulk rock porosity.

67-70 Sandy biosparite (coquina), fine to medium calcirudite; allochems; mollusk shells and shell fragments, foraminifera, high bulk rock porosity.

70-72 Same as 67 to 70 feet, with greater percent of sparite cement (recrystallization), large number of moldic pores that hint at a coquinoid origin high bulk rock porosity.

72-73 Same as 70 to 72 feet, with a slight decrease in the amount of sparite cement, high to very high bulk rock porosity.

73-78 Sandy biosparite (coquina), fine calcirudite, white to brown, mollusk shells, foraminifera, high to very high bulk rock porosity.

78-80 Calcareous sandstone, white to gray; allochems; algae 10 percent, well preserved gastropod and pelecypod shells 2 percent, foraminifera 5 percent, medium to coarse sand size, angular to rounded; terrigenous grains; quartz 50 percent, sparite cement, intergranular porosity 10 percent, low to medium bulk rock porosity.

80-90 Calcareous sandstone at the top grading toward a sandy coquina near the bottom, tan to brown; allochems; mollusk 10 to 30 percent, foraminifera 10 percent, fine to medium sand size, subangular to subrounded (weak alignment of elongate grains); terrigenous grains; quartz, 30 to 40 percent, medium sand size, subrounded to well rounded, intergranular porosity 10 to 20 percent, high bulk rock porosity (vuggy); possible subaerial horizon.

90-100 Sandy biosparite (coquina), white to tan; allochems; pelecypod 10 percent, gastropod 40 percent, foraminifera 10 to 15 percent, fine sand to gravel size, angular to subrounded; terrigenous grains; quartz, 20 percent, medium sand, subangular to rounded, intergranular porosity less than 5 percent, medium to high bulk rock porosity.

100-107 Biosparite (coquina), white to tan; allochems; pelecypod 20 percent, foraminifera 1 percent, algae 30 percent, bryozoans 1 percent and micritic peloids medium to very coarse sand size, subangular to rounded; terrigenous grains; quartz, 10 percent, fine to medium sand, angular to rounded; intergranular porosity 5 to 10 percent, medium to high bulk rock porosity. 
Depth

(feet)

Description of sample

107-110 Biosparite (coquina), white to gray; allochems; pelecypods 30 percent, foraminifera 20 percent, peloids 5 percent, bryozoans 2 percent, algae 2 percent, echinoids 1 percent; fine sand to pebble (very coarse), subrounded to rounded; terrigenous grains; quartz (pyx?) 5 percent, fine to coarse sand, subangular to rounded (from 100 feet, sequence is coarsening down), intergranular porosity 20 to 30 percent, medium to high bulk rock porosity; subaerial horizon.

110-120 Biosparite (coquina), white to tan; allochems; pelecypods 30 percent, gastropods 10 percent, intraclasts (with ooids) 20 percent, foraminifera 5 percent, fine sand to pebble size, subangular to rounded; terrigenous grains; quartz 10 to 30 percent, quartz grain content is greater at the top than the bottom, fine to coarse sand size, angular to subrounded; intergranular porosity 10 to 20 percent, medium to high bulk rock porosity; fining upward sequence, top of section consists of a subaerial crust, with very fine sand size bioturbated sediments, bottom well indurated shell hash (top very vuggy; bottom few vugs), micrite is recrystallizing to sparite.

120-130 Biosparite, white to gray, medium to very coarse calcarenite, well indurated skeletal fragments; allochems; foraminifera 20 percent, pelecypods 10 to 15 percent, rounded to subrounded, medium to coarse sand size; terrigenous grains; quartz, calcite, less than 5 percent, subangular to subrounded, medium sand; intergranular porosity 20 percent, medium bulk rock porosity, much recrystallization.

130-140 Biosparite, medium to very coarse calcarenite, gray to brown, mollusk shell, bryozoan, forams, ostracods, and algae (10 percent recovery), medium bulk rock porosity.

140-148 Sandy biomicrite, white to gray; allochems; bryozoans 40 percent, pelecypods 5 percent, algae 5 percent, echinoid 2 percent, foraminifera 1 percent, angular to subangular, fine sand to pebble size; terrigenous grains; quartz, feldspar, minor iron, angular to subrounded, fine to coarse sand size; fining downward sequence, pebble size at top and medium to coarse sand at the bottom; intergranular porosity less than 10 percent, medium to high bulk rock porosity, much recrystallization and dissolution; possible subaerial horizon at 145 to 150 feet.

148-157 Biosparite, white to tan to gray; allochems; pelecypod, gastropod and foraminifera combined, 50 percent, algae 2 percent, rounded, fine sand; terrigenous grains; quartz 10 percent, autogenic quartz overgrowths, uniform microsparite, angular to rounded, fine sand; coarsening down, sequence medium sand at top and pebble size at the bottom; at 151 to 153 feet, vugs filled with bladed sparry calcite, bioturbated, intergranular porosity 5 to 10 percent, high to very high bulk rock porosity; possible subaerial horizon at 154 to 157 feet.

157-161 Biosparite, calcarenite-calcirudite, white to tan, medium sand at the top and pebble size grains at the bottom, coarsening down sequence, mollusk skeletal fragments, pits and vugs, high bulk rock porosity.

161-164 Sand stringer, no recovery; subaerial horizon. 
Depth

(feet)

Description of sample

164-170 Biosparite, calcirudite, white to tan (coquina), molluscan skeletal material, well indurated, vugs with sparry calcite, top part of section very similar to 159 to 160 feet and grades into coquina, high whole rock porosity.

170-179 Sandy biosparite, tan, allochems; bryozoans 5 percent, foraminifera 5 percent echinoids 1 percent, algae 1 percent, angular to subrounded, fine to coarse sand size; terrigenous grains; quartz, amphibole, 20 percent, angular to subrounded, fine to coarse sand size, well indurated, grain size increasing from top to bottom intergranular porosity 20 to 30 percent, medium to high bulk rock porosity.

179-180 Biosparite, fine to medium calcirudite, white to tan (shell hash), section grades from very coarse calcarenite at the top to a medium calcirudite in the middle to a fine calcarudite at the bottom; allochems; mollusk shells, algae, bryozoans and foraminifera, intergranular porosity 5 to 10 percent, medium to high bulk rock porosity.

180-182 Biosparite, coarse calcirudite, white to yellow to orange (shell hash); allochems; mollusk shells, forams, algae, and bryozoans, intergranular porosity 5 to 10 percent, high bulk rock porosity.

182-188 Sandy, biosparite, white to gray; allochems; pelecypod 30 percent, foraminifera 2 percent, bryozoans 1 percent, algae 1 percent, angular to rounded, fine to medium sand size, burrows filled with micrite and sparry calcite, vugs filled with sparry calcite; terrigenous grains; quartz, feldspar, 10 to 20 percent, angular to subrounded, fine to coarse sand size; intergranular porosity 5 to 10 percent, medium to high bulk rock porosity; advanced stage of recrystallization, degree of recrystallization increases downward.

188-190 Biosparite, fine calcarudite, white to tan (shell hash), very slight fining down sequence from 185 feet; allochems; mollusk shell fragments and forams, very high bulk rock porosity.

190-194 Biomicrite, fine to coarse calcarenite, tan; allochems; molluscan skeletal material, medium to high bulk rock porosity.

194-200 Biosparite, white to tan, well indurated coquina with concretions and burrows (190 to 200 feet, 40 percent recovery); allochems; pelecypod 30 percent, foraminifera 5 percent, algae 5 percent, echinoid 1 percent, angular to subrounded, fine coarse sand size, many of the skeletal fragments have a weak alignment of their long axis and geopetal structures; terrigenous grains; quartz, feldspar, calcite, 5 to 10 percent, angular to rounded, fine to medium sand; intergranular porosity 5 to 10 percent, high bulk rock porosity, very recrystallized.

200-210 Biomicrite, fine calcirudite, gray to yellow to tan (shell hash); allochems; mollusk shell fragments and foraminifera, slight fining downward (200 to 210 feet, 20 percent recovery), large vugs, high bulk rock porosity. 
Depth

(feet)

Description of sample

210-220 Biomicrite, fine calcirudite, white to gray, shell hash, small vugs, fining down; allochems; mollusk shell fragments, high to medium bulk rock porosity.

220-250 Sandy biosparite, white to gray to tan; allochems; pelecypods 30 percent, foraminifera 2 percent, bryozoans 2 percent, angular to rounded, mostly fine sand size, less than 1 percent pebble size; terrigenous grains; quartz, feldspar, 30 to 40 percent, angular to subrounded, fine sand size (from 230 to 240 feet, 7 feet of loose sand not recovered; from 240 to 250 feet, 8 feet of sand not recovered), intergranular porosity 5 to 10 percent, medium to high bulk rock porosity, not as recrystallized as 210 to 220 feet.

250-260 Calcareous sandstone, tan to light-brown; allochems; pelecypod 15 percent, gastropod 10 percent, foraminifera 5 percent, bryozoan 1 percent, echinoid 1 percent, angular to well rounded, fine sand to pebble size; terrigenous grains; quartz, calcite, 30 to 40 percent, angular to rounded, fine sand to pebble size; intergranular porosity 20 to 30 percent, medium to very high bulk rock porosity.

260-270 Biosparite, coarse calcirudite, gray-tan; allochems; mollusk shells, foraminifera, moldic pores and burrows (shell hash), 260 -foot sand stringer not recovered, high bulk rock porosity. 


\section{Test Hole G-3472}

[Descriptions by Joseph F. Whitley, U.S. Geological Survey, Miami; several holes were drilled because drillers encountered difficulties in keeping rig stable while drilling through beds of sand]

U.S. Geological Survey identification number: 255648080072101

U.S. Geological Survey local number: G-3472

U.S. Geological Survey project identification number: BRS-4

Location: Sunny Isles, about 15 feet south of the center of 185th Street between N. Bay Road and Atlantic

Boulevard. Site was next to wall enclosing parking lot of rental car company.

Date cored: February 1990; three holes were drilled and filled in afterward.

Depth

(feet)

Description of sample

\section{Hole 1}

0-10 Steel reinforced concrete (old building structure, possibly an old foundation).

10-15 Medium to coarse-grained calcirudite (biolith?), gray to tan, mollusk shell fragment (as well as whole shells), coral fragments (Montrastrea), burrows; low to medium porosity.

15-20 Medium to coarse grained calcirudite, gray to tan mollusk shell and shell fragments, coral fragments, burrows (more gray than at 10 to 15 feet), coral recrystallized with sparry calcite and some parts of the coral are gray and some are white (gastropod shell usually gray); low to medium porosity.

\section{Hole 2}

20-30 Medium grained calcarenite, white to gray, shell fragments, well cemented, but sample represents less than 10 percent recovery; low porosity.

30-35 Medium grained calcirudite, tan to gray, mollusk shell and shell fragments, bryozoan colonies, micrite cement, most gastropod shells gray to black, parts appear to be medium grained calcarenite, parts appear as shell hash as well; samples highly variable, may not represent this interval exclusively; low porosity.

35-40 Medium to coarse grained calcirudite, tan to gray, shell hash (mollusk shells), a few whole but mostly shell fragments, well cemented, medium to high porosity, shell hash; top part about 35 feet, medium grained calcirudite similar to pieces in 30 to 35 feet (also vuggy), other part has gray horizontal sections of gray micrite above and below which are shell hash; transition (may be contact [Key Largo-Anastasia]).

40-45 Fine to medium grained calcarenite, tan to light-gray, vuggy and pitted, well indurated, some larger shell fragments (mollusk) and burrows; low to medium porosity; possible subaerial horizon.

45-50 Top is fine to medium grained calcarenite, white to tan (vuggy), about 46 feet change to medium to coarse grained calcirudite, shell hash similar to 35 to 40 feet. 
Depth

(feet)

Description of sample

\section{Hole 2--Continued}

50-60 No recovery.

60-65 Medium to coarse grained calcirudite, gray to tan, shell hash (mollusk shell); high porosity.

65-70 Same as for 60 to 65 feet, grain size slightly less; possible subaerial horizon.

\section{Hole 3}

60-65 Coarse to medium grained calcirudite (biolith), tan to gray, gray parts contain calcarenite with shell fragments, vuggy; tan parts contain coral (Diploria and Montastrea), some in apparent living position; high porosity.

65-70 Same as 60 to 65 feet.

70-72 Fine to medium grained calcirudite, gray to tan, with coral fragments in matrix and much recrystallization; high porosity.

72-74 Same as 70 to 72 feet.

74-75 Fine calcirudite to coarse calcarenite, gray to tan, gastropod shells, some small coral fragments; vuggy, medium to high porosity.

75-80 Medium calcarenite, white to tan, small percentage of fine shell fragments (less than 10 percent recovery); subaerial horizon.

80-82 Coarse grained calcarenite to medium grained calcirudite; calcarenite, tan, same as 75 to 80 feet; calcirudite, tan to gray, shell hash with few coral fragments within hash; high to medium porosity.

82-83 Same as 75 to 80 feet.

83-85 Same as 82 to 83 feet (thin section), color slightly more orange than tan.

85-88 Same as 83 to 85 feet.

88-90 Same as 83 to 85 feet, grain size increase, fine-grained calcirudite.

90-100 Fine to medium grained calcirudite, increase in grain size, tan to light-gray, shell fragments, detrital carbonate fragments; medium to high porosity.

100-110 Coarse grained calcarenite, white to gray, shell fragments and detrital carbonate grains, well cemented and recrystallized; pits and small vugs, medium to high porosity. 
Depth

(feet)

Description of sample

\section{Hole 3--Continued}

110-114 Some rounded fragments of calcarenite in unconsolidated brown carbonate sand; calcarenite, gray, fine to medium grained; sand, brown, medium to coarse grained.

114-120 Fine to medium grained, white to gray, friable and broken pieces; low porosity.

120-124 Fine grained calcarenite, tan to orange, some orange may be rust from being left in core barrel in the borehole; large to medium vugs, medium to low porosity.

124-128 Medium to fine grained calcarenite, white to gray, broken pieces similar to 114 to 120 feet but not as friable; low porosity.

128-140 Medium to fine grained calcarenite, tan to orange, same as 120 to 124 feet; bottom at about 137 to 140 feet has more and larger vugs and higher porosity.

140-150 Fine to medium grained calcarenite, tan to orange; similar to 137 to 140 feet with same number of vugs (large), high to medium porosity.

150-160 Fine to medium grained calcarenite, tan to orange, some vugs and pits, bottom of core is about 155 to 160 feet, broken pieces (more fractures in rock), solid pieces show more and larger vugs. 


\section{APPENDIX 2}

\section{Photographs of Cores from Test Holes \\ G-2610 and G-3472}




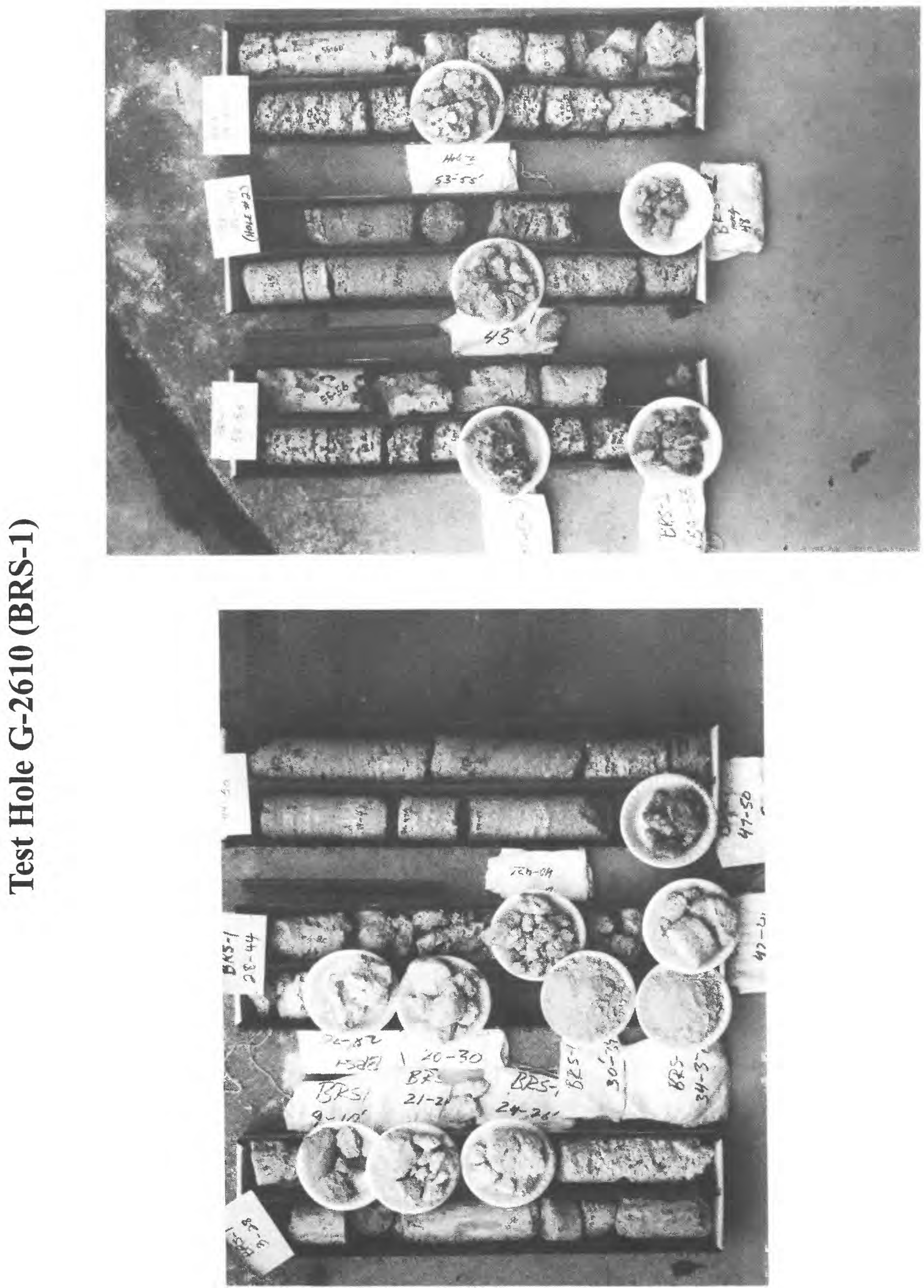




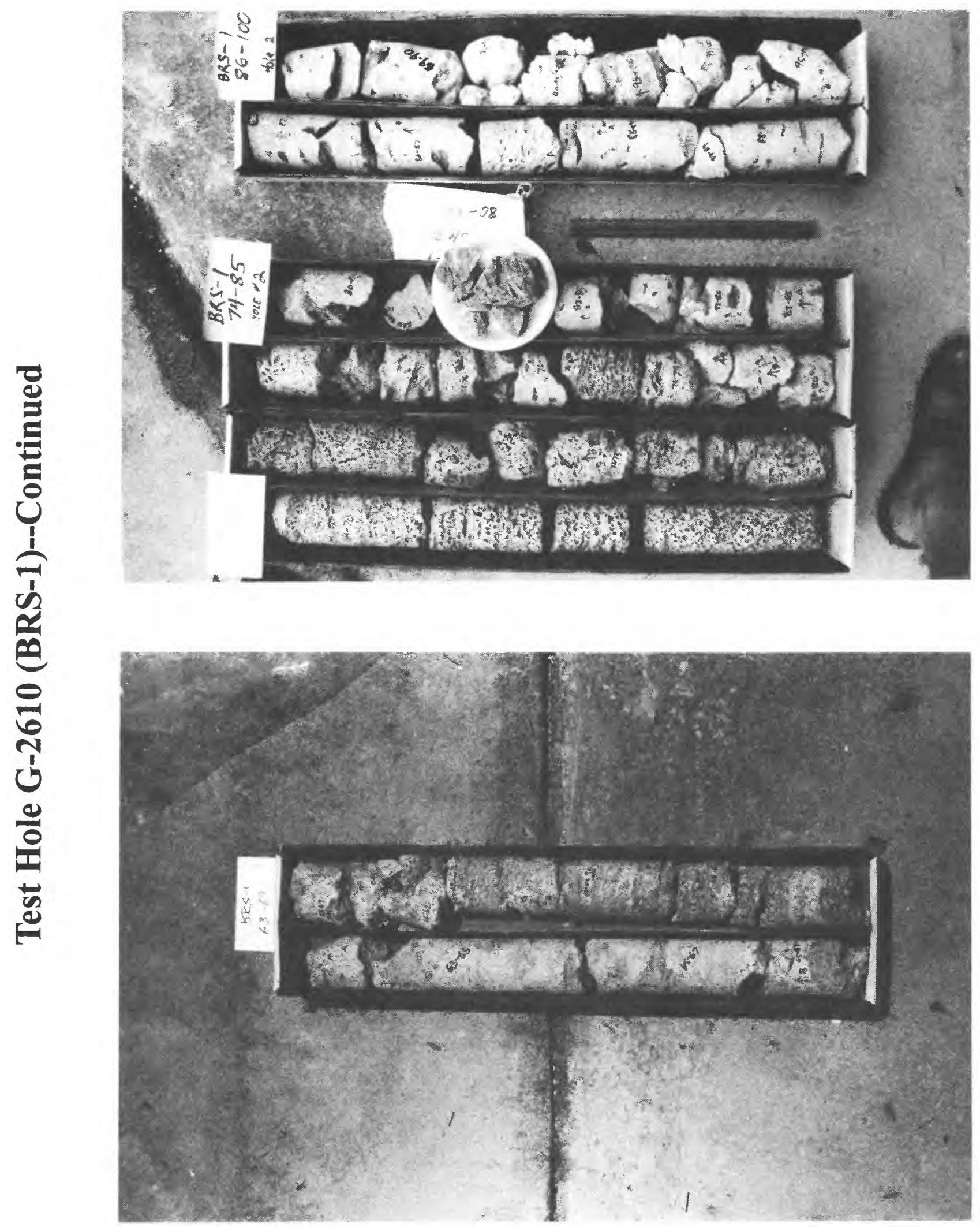




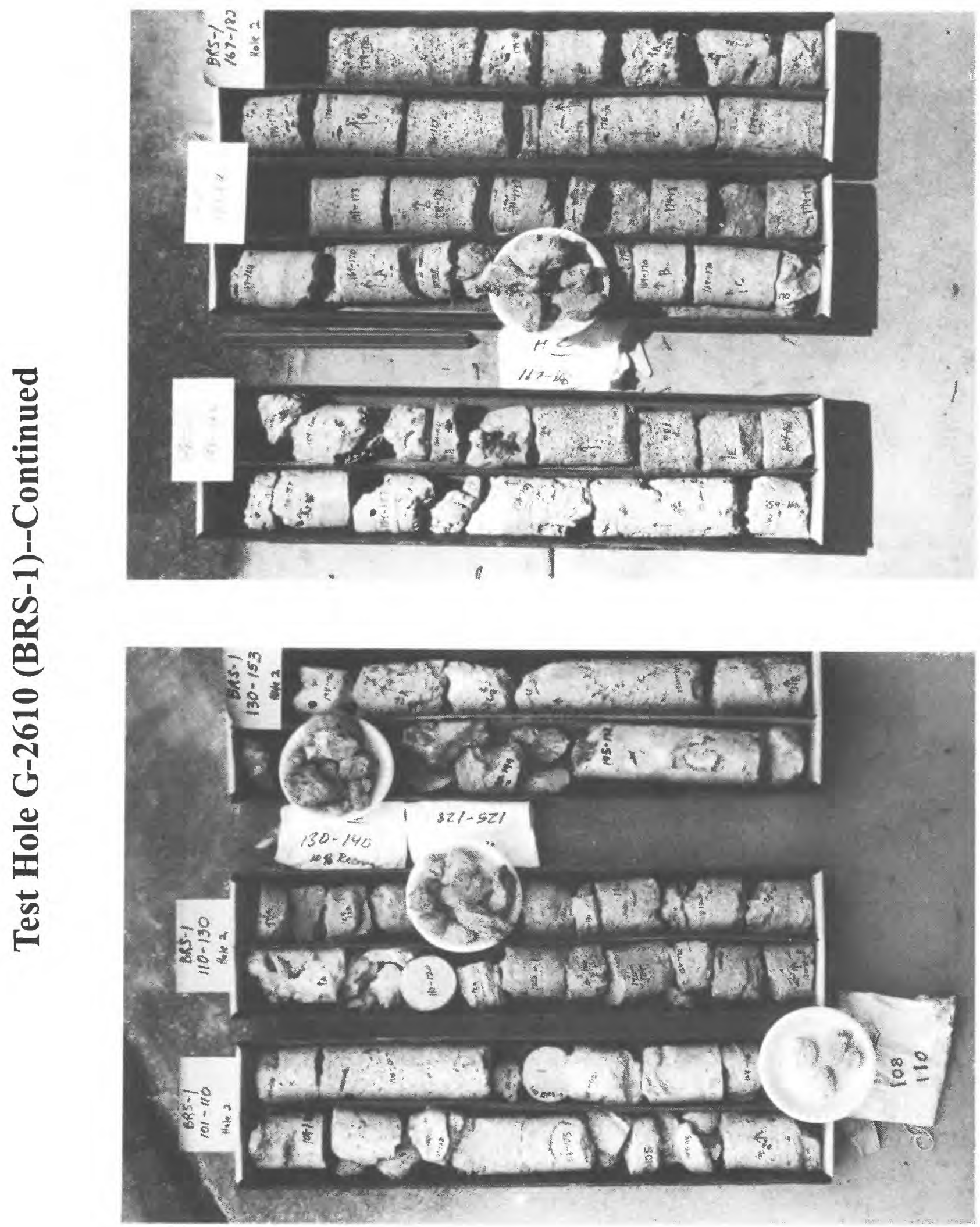




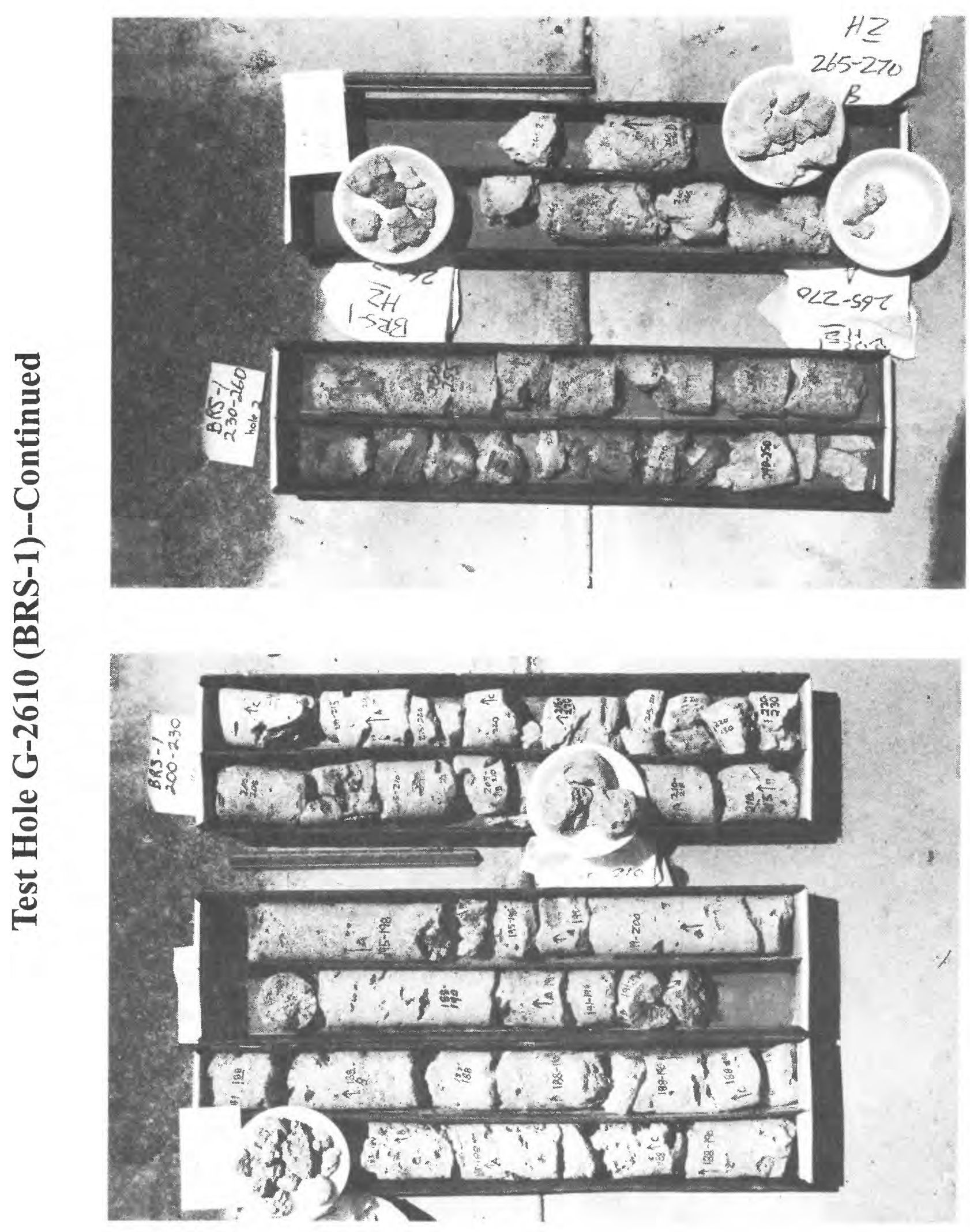




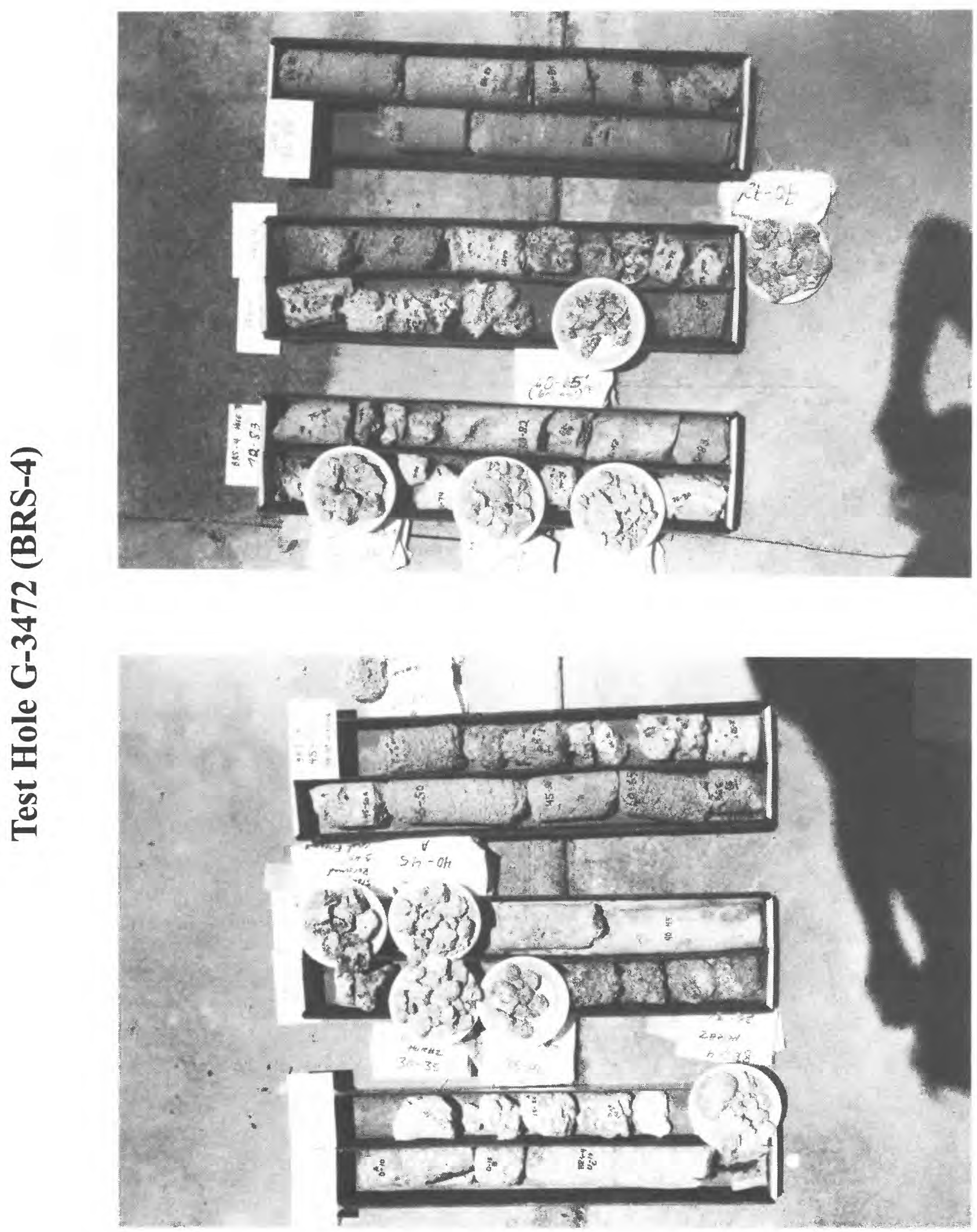




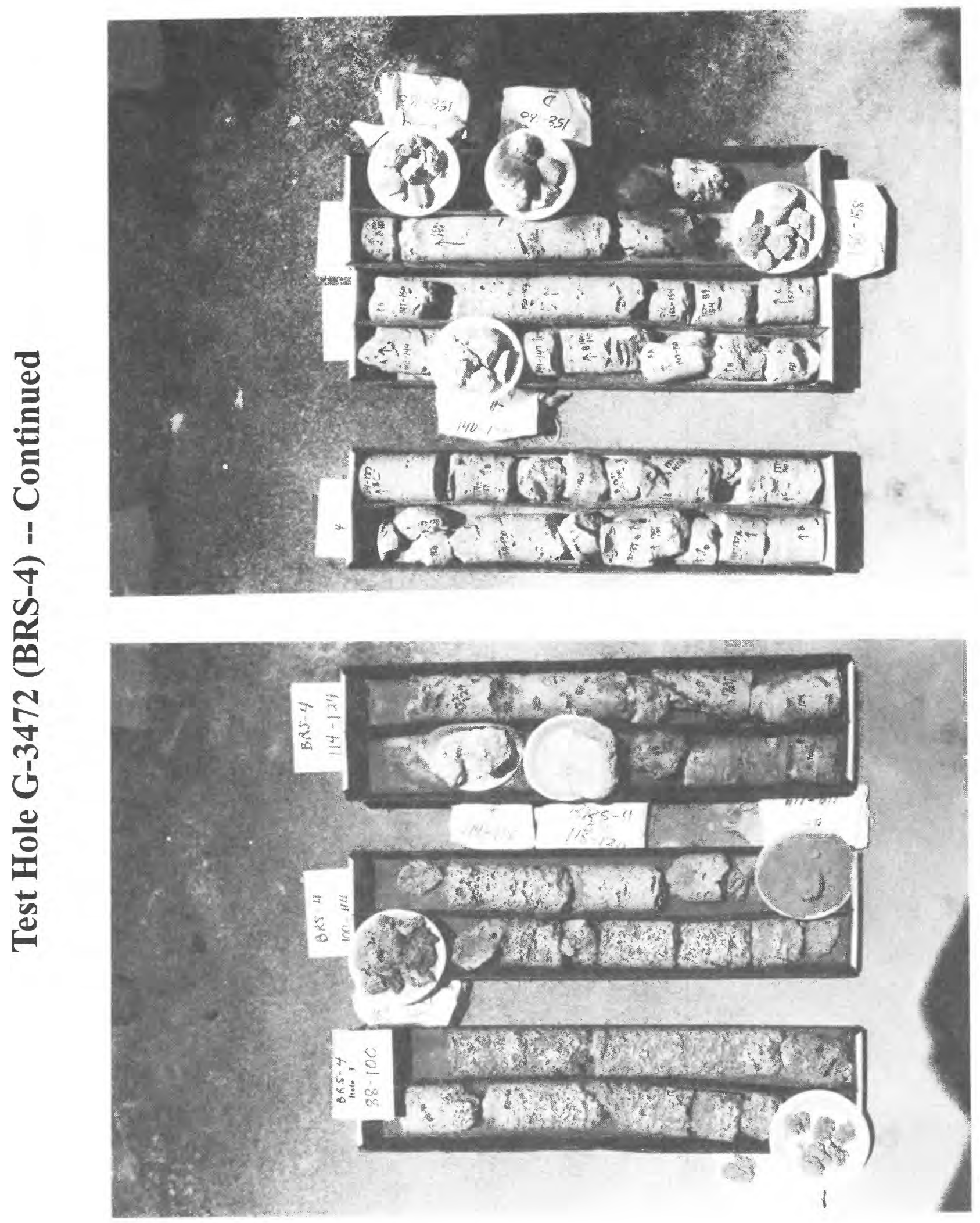




\title{
APPENDIX 3
}

\author{
Solution Porosity Logs of Test Holes \\ G-2328, G-2610, and G-3472
}




\section{TEST HOLE G-2328}

[Prepared by visual inspection of samples by J.E. Fish and M.L. Merritt, U.S. Geological Survey, Miami, late 1981; drilling with dual-tube reverse-air and using a modified core barrel produced "chip cores"]

Depth

(feet below

Description

land surface)

0-9 Sand.

9-33 Some solution holes present, decreasing in number to 33 feet.

33-36 Good permeability, fine holes in sandstone.

36-46 Bigger holes in grainstone and sandstone, alternating limestone and sand layers.

46-49 Layer of hard limestone.

49-52 Fossilized coral, tight, low permeability.

52-80 Main producing zone, large cavities, good permeability, clean holes in rock (no sand).

80-120 Smaller holes, still highly permeable, some sand in channels.

120-133 Pencil-lead size channels in rock (some filled with sand), probably good permeability.

133-143 Cavities, but less evidence of solution paths.

143-153 Sand.

153-163 Tiny shells in matrix, low permeability.

163-166 Consolidated sandstone, permeability probably relatively low.

166-213 Sand and sandstone with nodules of limestone, permeability relatively low.

213-219 Rock with rib-like structure, possibly some permeability.

219-223 Fine sand, cemented, permeability low.

223-246 Similar to 166 to 213 feet.

246-252 Sandstone, good permeability.

252-258 Tight rock, fine sand, permeability relatively low.

258-262 Permeable rocky layer.

262-266 Similar to 252 to 258 feet.

266-273 Consolidated rock, anastomosing solution features, good permeability.

273-279 Similar to 166 to 213 feet.

279-289 Sand and sandstone that is finely notched, but permeability probably relatively low.

289-300 Greenish claystone, permeability negligible. 


\section{TEST HOLE G-2610 (BRS-1)}

[Prepared by visual inspection of samples by M.L. Merritt and R.S. Reese, U.S. Geological Survey, Miami, April 1994]

Depth

(feet below

Description

land surface)

\section{Hole 1}

0-28 From 26 to 28 feet, oolite, shows, pinhole porosity.

28-44 From 35 to 40 feet, sand; below 40 feet, some evidence of porosity (broken rock, smooth surfaces), looks recrystallized, porous.

44-50 From 44 to 47 feet, coquina, not highly permeable (a few pinpoint pores); from 48 to 50 feet looks like solution features (infillings of calcite or dolomite(?).

50-56 From 50 to 53 feet, originally coquina, quite permeable (infillings in vugs); from 54 to 55 feet, originally coquina, highly permeable (deposits of crystallized substances in holes); from 55 to 56 feet, much finer grained, but still coarse, not coquina, large holes but not smooth inside, some dark-gray lining of holes but no recrystallization.

\section{Hole 2}

45-48 Same as above.

48-62 From 48 to 55 feet, very porous; from 55 to 62 feet, large holes, not smooth, probably solution channels to 60 feet, less solution holes from 61 to 62 feet.

62-69 From 63 to 66 feet, not highly permeable; from 67 to 69 feet, coarse coquina, recrystallization, some possible fine porosity (solution).

69-74 Same as above, solution and recrystallization of coquina, some permeability.

74-85 Same as above to 76 feet, then a few large holes with infilling; from 76 to 78 feet, a lot of dissolution in coquina (repeat of above, 44 to 66 feet, coquina underlain by finer grain material with large solution holes); to 85 feet probably permeable; from 83 to 85 feet, fractures, large holes, much discoloration along solution channels.

85-100 Same as above to 100 feet.

100-110 Coarser grained than above, a few scattered solution holes, less deposit on the sides of the holes; little solution below 106 feet.

110-130 Highly permeable at 110 feet (most samples missing to 120 feet); very fine grained aggregate of "lime balls" (a disturbed paleo soil?); below 120 to 130 feet, possible slight permeability (a few solution holes); larger holes might be the result of drilling if they were infillings of lime or sand, but no obvious "pattern" to them. 
Depth

(feet below land surface)
Description

\section{Hole 2--Continued}

130-153 From 130 to 145 feet, large solution holes lined with deposits; below 145 feet, chalky, holes not lined with deposit; holes from drilling(?); some holes probably already there--maybe infilled with mud.

153-166 From 154 to 157 feet, some good solution holes, generally like above; from 158 to 159 feet, like 145 to 153 feet; from 164 to 166 feet, coquina, permeability questionable, possible minor permeability.

166-176 Same (coquina), minor permeability; from 171 to 174 feet, solution holes lined with dolomite(?).

176-182 Coquina, small solution holes with dolomite(?), infilling to 178 feet; from 179 to 180 feet, larger holes, much infilling; huge hole at 181 feet.

182-190 Coarse-grained limestone, scattered large solution holes with crystallization.

190-200 Same.

200-230 Same material, high permeability, large holes with crystallization in channels; poor core recovery in some intervals.

230-260 From 230 to 250 feet, fine-grained or recrystallized material, lots of iron precipitate to 240 feet, lots of large solution channels; from 250 to 260 feet, coquina, smaller holes, less holes but still permeable. 


\section{TEST HOLE G-3472 (BRS-4)}

[Prepared by visual inspection of samples by M.L. Merritt and R.S. Reese, U.S. Geological Survey, Miami, April 1994; samples retrieved with 4-inch core barrel]

Depth

(feet below

land surface)
Description

0-30 From 1 to 15 feet, low porosity; from 15 to 20 feet, some solution holes with infilling of lime mud; from 20 to 30 feet, low porosity.

30-45 From 30 to 35 feet, bed of dense limestone with solution cavities on top, below is sandstone; from 35 to 40 feet, shall hash, not highly dissolved, permeability questionable, looks eroded from side, but top and bottom of samples nearly smooth; about 40 feet, fossil coral, permeable, solution channels with darkbrown and dark-gray deposits; 40 to 45 feet, sandstone, has holes but permeability questionable, holes look like burrows.

45-72 From 45 to 50 feet, shell hash, not highly crystallized, very light, possibly porous, but no obvious holes and permeability unknown; from 50 to 60 feet, no samples; from 60 to 65 feet, fossil coral, highly dissolved out, gray blotches look like deposits in channels, underneath is coquina (shell hash), crystallized, permeability unknown; from 65 to 70 feet, coquina, possibly a few large solution channels, otherwise looks tight, below is limestone with some large solution channels infilled with crystals; from 70 to 72 feet, fossil coral, dissolved out, brown crystalline (quartz) material deposited in channels, also dark-gray deposits.

72-83 From 72 to 75 feet, same as 70 to 72 feet; from 75 to 80 feet, poorly cemented sandstone, not much permeability; from 80 to 83 feet, sandstone with some burrows, but not highly permeable.

83-88 This fine-grained shell hash is mainly tight, maybe a few small solution holes.

88-100 This coarser grained shell hash probably has minor permeability.

100-114 From 100 to 102 feet, possible solution zone, poor sample recovery; from 102 to 110 feet, highly recrystallized shell hash, lots of solution holes with deposits, probably highly permeable; from 110 to 114 feet, sand, low recovery.

114-124 From 114 to 120 feet, low recovery, chalky, poorly consolidated massive limestone, low permeability; from 120 to 124 feet, medium to fine-grained limestone, a few large, obvious solution holes with a lining of deposits.

124-140 Same as 120 to 124 feet; dissolution seems to follow bedding planes.

140-154 From 140 to 144 feet, poor sample recovery; from 144 to 154 feet, same as 120 to 140 feet, but solution holes less numerous.

154-160 Same as above, more solution holes below 156 feet, sample recovery poor. 